UNIVERSIDADE DE SÃO PAULO

INSTITUTO DE GEOCIÊNCIAS

\title{
ANÁLISE DOS ESTROMATÓLITOS DO GRUPO ITAIACOCA (PROTEROZÓICO), AO SUL DE ITAPEVA, SP
}

\author{
William Sallun Filho \\ Orientador: Prof. Dr. Thomas Rich Fairchild
}

DISSERTAÇÃO DE MESTRADO

Programa de Pós-Graduação em Geologia Sedimentar

SÃO PAULO

1999 


\section{RESUMO}

Estromatólitos foram estudados em nove localidades ao sul de Itapeva (SP), principalmente em metacalcários dolomíticos cinza-claro e, secundariamente, em metacalcários calcíticos cinza-escuro, do Grupo Itaiacoca, uma unidade vulcanossedimentar mesoproterozóica da Faixa Ribeira. Foram diferenciados em cinco formas colunares, a mais comum consistindo de colunas coniformes, não ramificadas, de diâmetros e alturas centimétricas a decimétricas, atribuídas a Conophyton. As outras quatro formas, com laminação convexa mas não coniforme, diferem em tamanho, silhueta e estilo/freqüência de ramificação.

As diferenças na preservação dos estromatólitos são relacionadas ao comportamentos tectônicos distintos entre o metacalcário dolomítico (mais puro), com comportamento competente, e o calcítico (mais argiloso) que atuou de forma mais plástica.

Nas melhores exposições desta área os estromatólitos estão agrupados em bioermas de Conophyton, sem indícios de exposição ou retrabalhamento sub-aéreo ou por ondas, evidenciando um ambiente calmo e relativamente profundo, provavelmente abaixo do nível de base de ondas, de talvez até algumas dezenas de metros de profundidade.

Conophyton de Itapeva é semelhante a estromatólitos coniformes próximo a Abapã (PR), também no Grupo Itaiacoca, a cerca de $100 \mathrm{~km}$ de Itapeva, mas difere de outras formas, incluindo Conophyton cylindricum e C. metulum, de unidades proterozóicas associadas a margem oeste do Cráton do São Francisco. O Conophyton do Grupo Itaiacoca é semelhante a formas na ex-União Soviética que são geralmente encontrados no Mesoproterozóico ou Neoproterozóico inferior, que é consistente com as datações radiométricas disponíveis que colocam esta unidade próximo ao final do Mesoproterozóico. 


\section{ABSTRACT}

Stromatolites were studied at nine localities south of Itapeva, São Paulo, Brazil, generally in light-gray metadolostones and secondarily in dark-gray metalimestones of the Itaiacoca Group, a Mesoproterozoic volcanosedimentary unit of the Ribeira Belt. Five columnar forms were distinguished, the most common consisting of unbranched, coniform columns, with centimetric to decimetric diameters and heights, attributed to Conophyton. The other four forms exhibit convex, but not coniform lamination and differ in size, silhouette and style/frequency of branching.

Differences in stromatolite preservation are related to the differing tectonic behavious of the purer and more competent metadolostones and the more argillaceous metalimestones which behaved more plastically.

In the best exposures in this area the stromatolites are grouped into Conophyton bioherms, without any evidence of subaerial exposure or reworking by waves, which suggests that they formed in a calm and relatively deep setting (perhaps up to several tens of meters in depth), probably below the base of fairweather water.

Conophyton from Itapeva is similar to other coniform stromatolites in the Itaiacoca Group near Abapã (Paraná), about $100 \mathrm{~km}$ SW of Itapeva, but differs from other forms, including Conophyton cylindricum and C. metulum, from Proterozoic successions associated with the western margin of the São Francisco Craton. The Conophyton from the Itaiacoca Group is most similar to forms in the ex-Sovietic Union that are usually found in the Mesoproterozoic or lowest Neoproterozoic, which is consistent with available radiometric age dates that place this unit near the end of the Mesoproterozoic. 


\section{AGRADECIMENTOS}

Gostaria de agradecer a todos aqueles que contribuíram de alguma forma, para realização deste trabalho.

Agradeço ao curso de Pós-Graduação do Instituto de Geociências da Universidade de São Paulo, particularmente ao Programa de Geologia Sedimentar pela possibilidade de realizar este trabalho e por todo o apoio concedido.

Os mais sinceros agradecimentos ao Prof. Dr. Thomas Rich Fairchild, pela orientação, desde meus primeiros anos de graduação, além do apoio e valiosa amizade.

À FAPESP pela concessão da bolsa (proc. $n^{0}$ 97/11435-3) e pelo financiamento das pesquisas através da reserva técnica da bolsa (proc. $n^{\circ}$ 98/01363-8) e do auxílio à pesquisa em nome do Prof. Dr. Thomas Rich Fairchild (proc. nº 97/13682-8).

À CAPES pela concessão de um ano de bolsa e pelo financiamento de alguns trabalhos de campo.

Ao Prof. Dr. Cláudio Riccomini pelo apoio durante o desenvolvimento deste trabalho e em diversas outras oportunidades anteriores. Ao Prof. Dr. Ginaldo A.C. Campanha pelas dicas, discussões e revisão da análise estrutural. Ao professor Miguel Basei pela oportunidade de acompanhar os trabalhos de campo da disciplina GGG-401 Geologia de Campo.

Às companhias Cimento Portland Itaú, da Pedreira Lavrinhas, e Cimento Portland Maringá, atual Minas Oeste, da Pedreira Indumine, sempre bastante prestativos e atenciosos nas visitas às pedreiras.

Aos técnicos dos laboratórios do IG-USP que de diversas maneiras auxiliaram este trabalho, em especial ao Laboratório de Tratamento de Amostras - José Paulo; Laboratório de Paleontologia Sistemática - Ivone; Centro de Pesquisas Geocronológicas - Vasco; Laboratório de Sedimentologia - Elaine; Laboratório de Microscopia Eletrônica Isaac; Laboratório de Informática - Rita e Márcia. Também ao Setor de Laminação, a garagem e a gráfica. A secretárias Sônia e Lúcia do antigo D.P.E. e Ana Paula e Magali da secretaria da pós-graduação.

Aos colegas de pós-graduação Fernando Mancini, Paulo Boggiani, André Ferrari, Renata Hidalgo, Paulo Albuquerque, Afonso Nogueira, Ana Paula, Renato, Alexandre Magno, Hélcio, Gilson, Ivo, Francisco William, Patrícia Cristalli, Alessandro Cesarino, Veridiana, Gaston, Cláudia Varnier, pela amizade e colaboração.

Agradecimentos aos colegas Ivan Delfini Neves pela inestimável ajuda durante a realização dos trabalhos, Victor Velázquez Fernandes pela amizade e acompanhamento em trabalho de campo, e Alexandre Carnier pelas dicas na utilização de programas de vetorização.

E um agradecimento muito especial à minha esposa Alethéa, por tudo o que ela representa na minha vida, e pelo carinho, paciência e apoio durante o desenvolvimento deste trabalho. 


\section{SUMÁRIO}

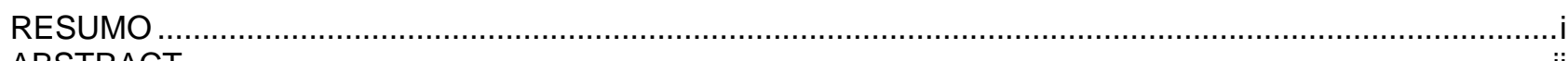

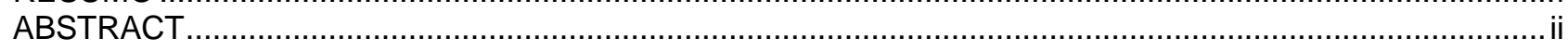

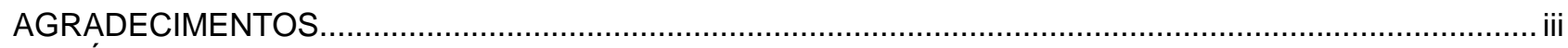

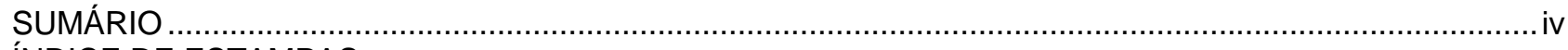

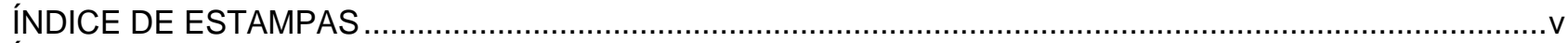

ÍNDICE DE FIGURAS.

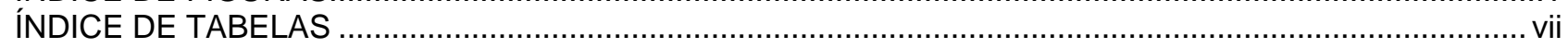

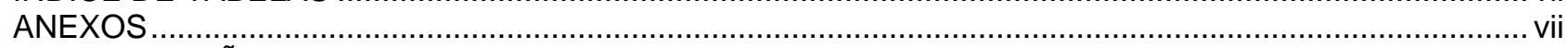

1. INTRODUÇÃO

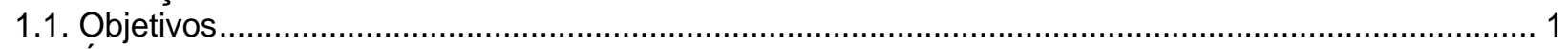

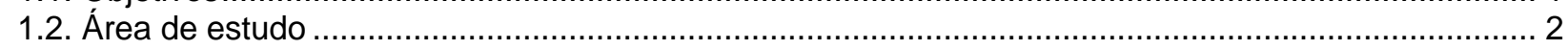

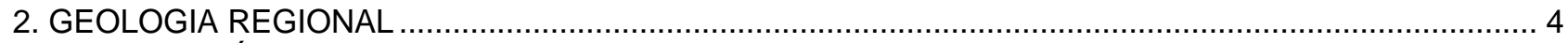

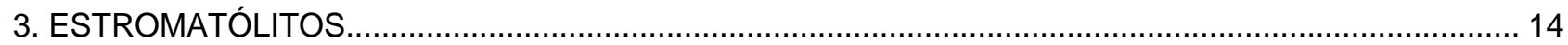

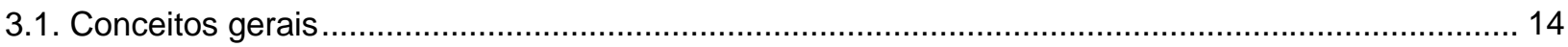

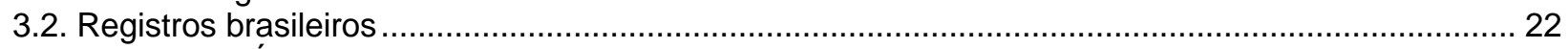

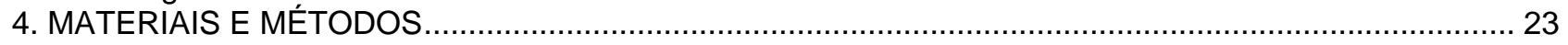

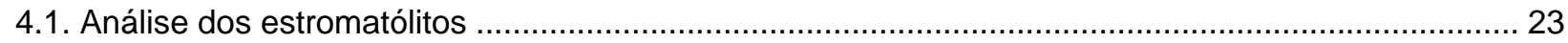

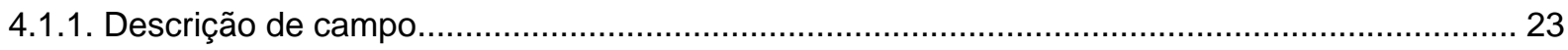

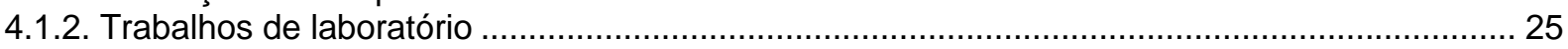

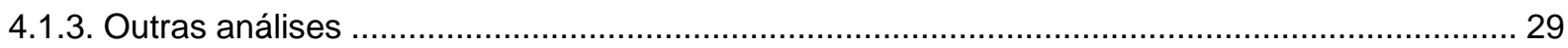

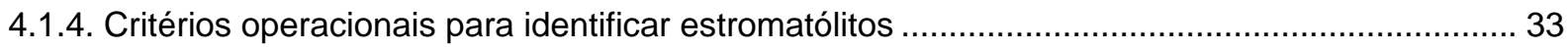

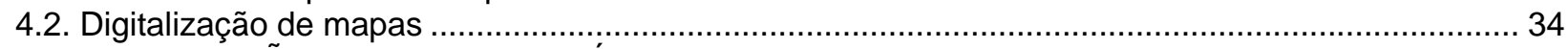

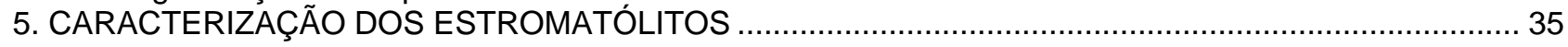

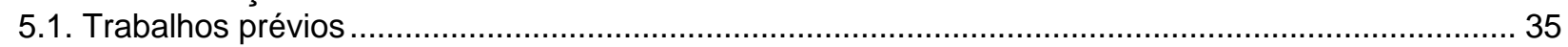

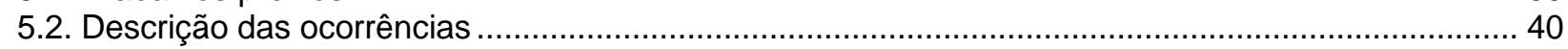

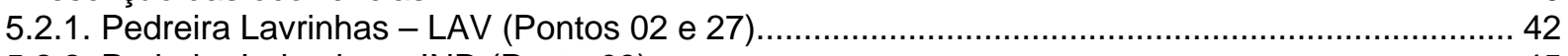

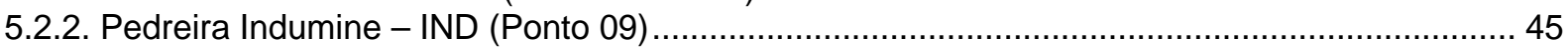

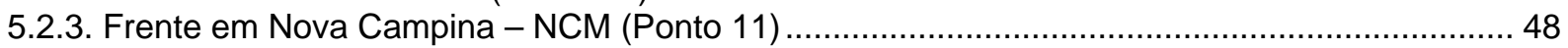

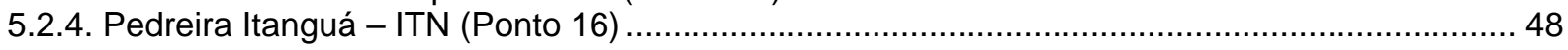

5.2.5. Pedreira na fazenda Santo Antônio - FSA (Ponto 17) …....................................................... 49

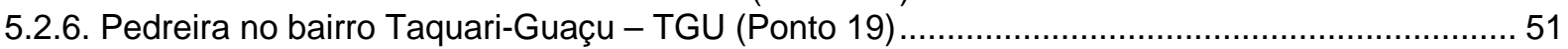

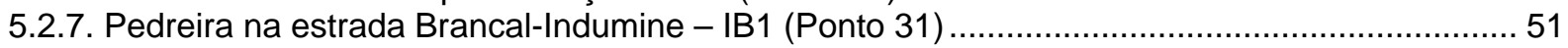

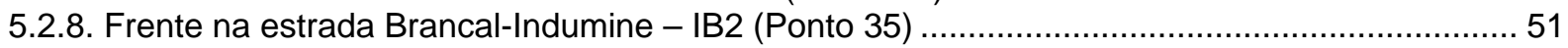

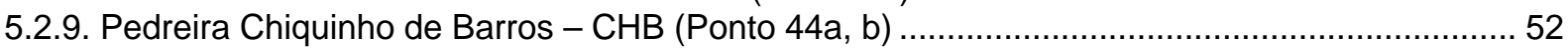

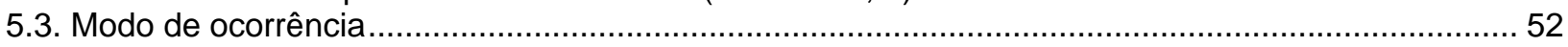

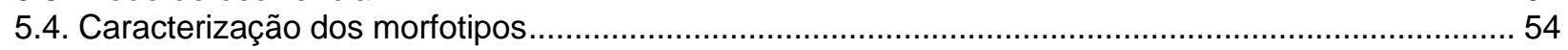

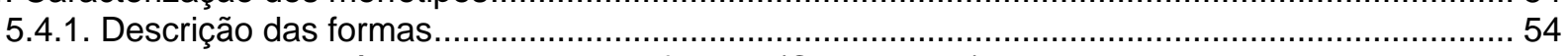

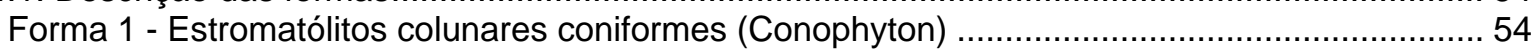

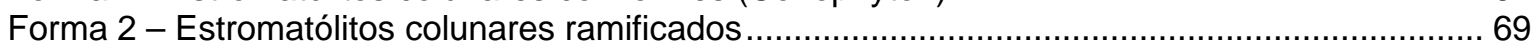

Forma 3 - Estromatólitos colunares não ramificados......................................................... 76

Forma 4 - Estromatólitos colunares divergentes............................................................. 79

Forma 5 - Estromatólitos turbinados ramificados............................................................ 80

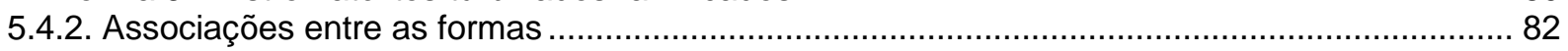

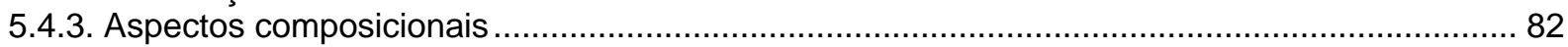

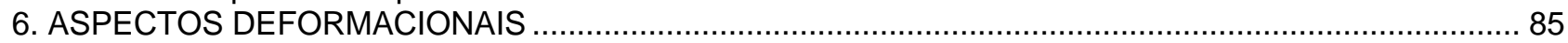

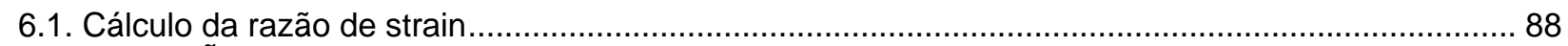

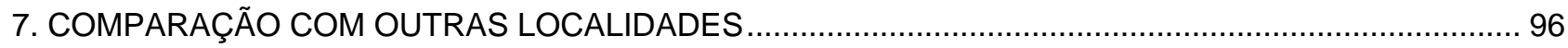

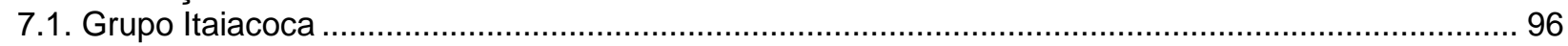

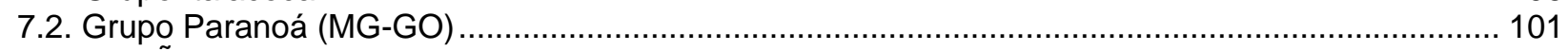

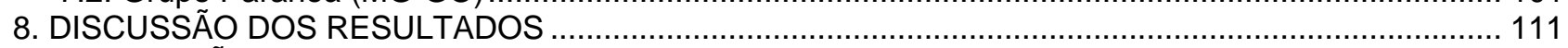

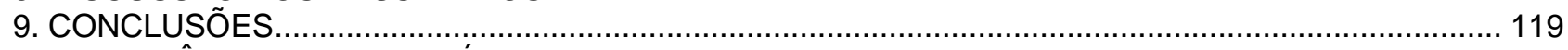

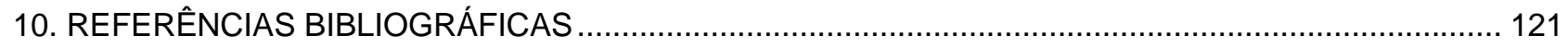




\section{ÍNDICE DE ESTAMPAS}

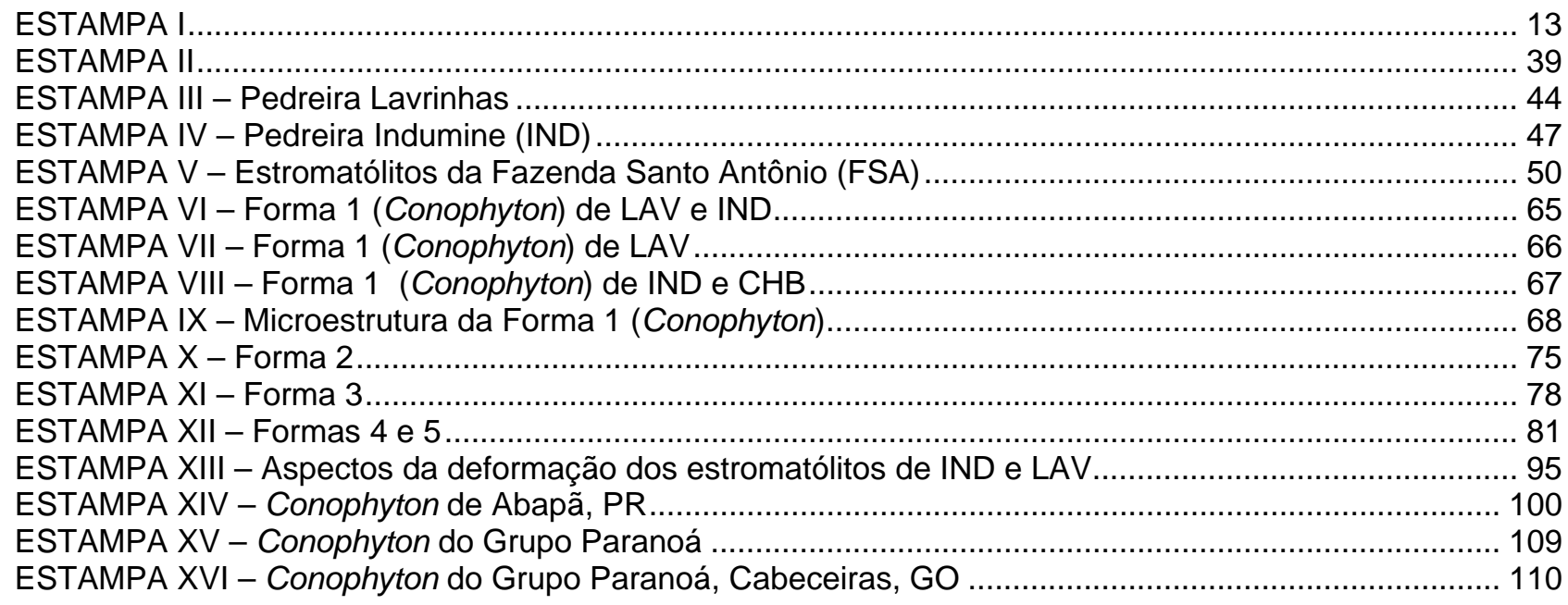

\section{ÍNDICE DE FIGURAS}

Figura 1: Mapa de localização e acessos (Fonte: Guia Quatro Rodas, 1994). .......................................... 3

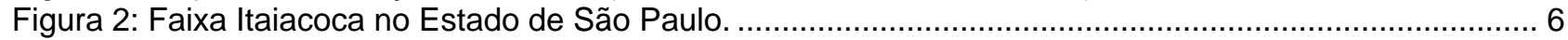

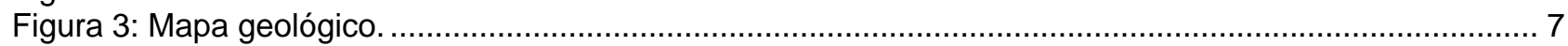

Figura 4: Relações estratigráficas no Grupo Itaiacoca segundo Theodorovicz et al. (1986). ...................... 8

Figura 5: Relações do estudo de estromatólitos e suas aplicações (Hofmann,1973)................................. 14

Figura 6: Gráfico triangular de Burne \& Moore (1987) ilustrando os três processos principais de formação

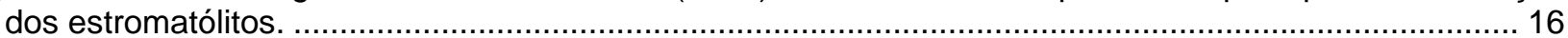

Figura 7: Sucessão evolutiva-ecológica da composição das microbiotas construtoras de estromatólitos no decorrer do tempo geológico (Walter, 1994) ............................................................................. 17

Figura 8: Influência relativa de fatores biológicos e ambientais na formação e morfologia de estromatólitos (Trompette, 1982) ......................................................................................................... 18

Figura 9: Interpretação paleoambiental a partir de tipos distintos de estromatólitos e estruturas sedimentares associadas no Grupo Dismal Lake, Canadá (Mesoproterozóico) (Donaldson, 1976)............................ 19

Figura 10: Variação das formas de estromatólitos em ambiente de rampa, segundo Grotzinger (1989)...... 19

Figura 11: Diversidade relativa (número de formas por intervalo de tempo) de estromatólitos no Fanerozóico e no Pré-Cambriano (Walter et al., 1992). A base de dados compreende mais de 800 formas encontradas em 200 bacias.

21

Figura 12: Padrões reconhecidos na distribuição dos estromatólitos ao longo do tempo geológico (baseado em Walter, 1994).

Figura 13: A - Exemplo de um bioerma com grande variedade morfológica, ilustrando a dificuldade de descrever estromatólitos. Segundo a parataxonomia desenvolvida pelos soviéticos, cada região marcada por uma letra diferente receberia uma designação binomial (grupo, forma) diferente. Ter-se-ia de coletar amostras para obter uma boa representatividade do conjunto (Krylov, 1976). B - Desenho mostrando a dificuldade da identificação de estromatólitos dependendo do tamanho da amostra (Krylov, 1976). Se a amostra fosse apenas A, C ou D o estromatólito não seria classificado como ramificado. ...................... 25

Figura 14: Amostra estromatolítica cortada em fatias (Walter, 1972).................................................... 26

Figura 15: Alguns dos caracteres medidos em amostras de estromatólitos colunares coniformes e não coniformes.

Figura 16: Guia para classificação de estromatólitos (Fairchild, inédito; adaptado de Grey, 1989)............... 32

Figura 17: Localização das principais ocorrências de estromatólitos descritas nas unidades carbonáticas da Faixa Ribeira, nos estados de São Paulo e Paraná. Dados geológicos extraídos de Bistrichi et al. (1981), em SP, e Mineropar (1989), no PR, e litoestratigrafia baseada em Campanha et al. (1987). ..............Erro! Indicador não definido.

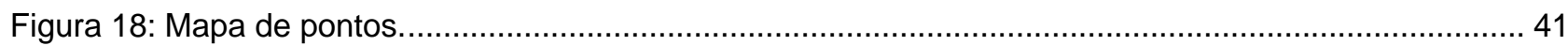

Figura 19: Esquema da estratigrafia de LAV, elaborado por T. R. Fairchild em 1980 (inédito). .......................42

Figura 20: Seção esquemática na pedreira Indumine (IND), baseada em T. R. Fairchild em 1976 (inédito),

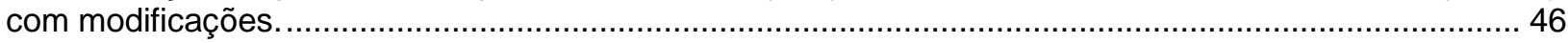

Figura 21: Critérios para distinguir estromatólitos coniformes de outros tipos. ......................................... 54 
Figura 22: Tipos de zona axial e, à direita de cada uma, os respectivos traços axiais unindo os pontos de maior espessura da laminação (modificado de Walter, 1972). A- alto grau de herança, B- baixo grau de herança.

Figura 23: Traços da laminação de amostras da Forma 1 de LAV, IND e CHB em corte longitudinal. Ver detalhes de C, D e I na Figura 24. A escala é igual para todas as figuras. A linha vertical em $\mathrm{H}$ demarca a margem da coluna; da mesma forma os contornos de colunas individuais estão demarcados em $F$ e $G$. A- LAV-01 (Est. VII-B); B- LAV-16; C- LAV-21 (Est. VII-D); D- LAV-25; E- IND-25; F- IND-24 (Est. VIII-E);

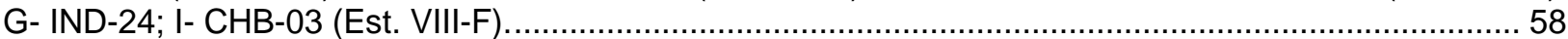

Figura 24: Detalhes da zona axial e seus respectivos traços axiais em amostras da Forma 1 de LAV e CHB. A escala é igual para todas as figuras. A- LAV-32 (lâmina) (Est. IX-A); B- LAV-21 (Figura 23 C; Est. VIID); C- LAV-25 (Figura 23 D); D- CHB-03 (Figura 23 I; Est. VIII-F).

Figura 25: Freqüência relativa das lâminas escuras (L2) e claras (L1) da amostra LAV-32. N=106 (L2) e 107 (L1).

Figura 26: Gráfico de Fairchild (1977) da freqüência relativa das lâminas escuras (L2) e claras (L1) da

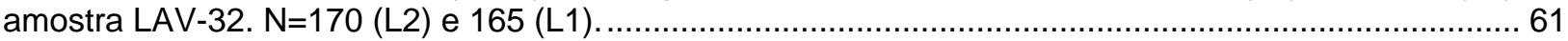

Figura 27: Desenhos da laminação elaborados a partir de fotografias de lâminas petrográficas. A área de cada desenho corresponde a $1 \mathrm{~cm}^{2}$. A - LAV - Est. IX-A; B - LAV - IX-C; C - IND - Est. IX-D..............62

Figura 28: Relações pressupostas de alguns tipos de estromatólitos com a profundidade da água, para a Formação Taltheilei (Paleoproterozóico do Canadá) (Hoffman, 1976). ...........................................63

Figura 29: Modelo de um assoalho marinho com diversas colunas de estromatólitos cônicos, como deve ter ocorrido em LAV. Os estromatólitos podem ter alcançado até $70 \mathrm{~cm}$ de relevo (Walter, 1977) .............63

Figura 30: Esquema de crescimento para a Forma 1, adaptado de Donaldson (1976), e na premissa que o crescimento vertical é favorecido em luminosidade baixa e o crescimento lateral em luminosidade alta. De $A$ para $C$ vemos um aumento da proximidade entre as colunas devido ao crescimento lateral. Há em C a formação de uma capa recobrindo diversas colunas agregadas.

64

Figura 31: Silhuetas de colunas da Forma 2 em cortes longitudinais. A escala é igual para todas as figuras. $\alpha$ = ponto de ramificação e $\mathrm{n}=$ projeção em nicho. A- LAV-15; B- LAV-12 (Est. X-B); C- LAV-29; DLAV-12; E- LAV-11 (Est. X-A); F- LAV-11; G- NCM-32 (Est. X-D); H-IB1-07 (Est. X-E). .................... 71

Figura 32: Silhuetas de colunas da Forma 2 em cortes transversais. A escala é igual para todas as figuras. A- LAV-11 (Est. X-F); B- LAV-29; C- LAV-15; D- NCM-32.

Figura 33: Silhuetas de colunas da Forma 2 vistas em cortes transversais e longitudinais ortogonais, na

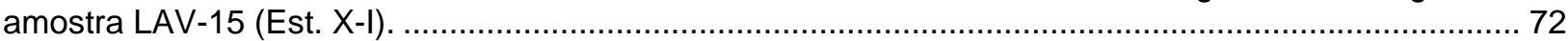

Figura 34: Laminação em corte longitudinal em amostras da Forma 2 de LAV, NCM e IB1. A- LAV-15 (Figura 31 A); B- LAV-12 (Figura 31 B; Est. X-B e C); C- LAV-29 (Figura 31 C); D- LAV-11 (Figura 31 F); E- LAV-11 (Figura 31 E; Est. X-A); F- NCM-32 (Figura 31 G; Est. X-D); G- IB1-07 (Figura 31 H; Est. X-E).

Figura 35: Laminação em corte longitudinal de amostras da Forma 3 de IB1, IND e LAV. A escala é igual para todas as figuras. As linhas verticais demarcam os limites das margens das colunas em A e C. AIB1-01 (Est. XI-B); B- IND-14 (Est. XI-D); C- LAV-18 (Est. XI-E); D- LAV-11..............................77

Figura 36: Quantidade de impurezas obtidas por dissolução de amostras de LAV, IND e FSA .................84

Figura 37: Elementos químicos maiores obtidos em análise química semi-quantitativa por EDS em amostras de LAV, IND e FSA.

Figura 38: Estereogramas de LAV. A - Medidas de acamamento de pedreira ativa de LAV (Pontos 01a, b, c, e). B - Medida de acamamento e direção das colunas de estromatólitos na frente abandonada de LAV (Ponto 02).

86

Figura 39: Estereograma de medidas de foliação $\left(S_{n}\right)$ e direção das colunas de estromatólitos em IND. .... 88

Figura 40: Relação das elipsidades $\left(R_{f}\right)$ com os diâmetros originais teóricos, para cada coluna medida em IND.

Figura 41: Aplicação do método de Fry (1979) em estromatólitos de IND, baseado na fotografia na Est. XIIIG. A - Centros das elipses das colunas de estromatólitos em corte basal. B- Diagrama final mostrando a distribuição dos pontos formando uma elipse no centro da figura, representada ao lado com o respectivo valor de $\mathrm{R}_{\mathrm{s}}$ e de orientação.

Figura 42: Mapa de localização das ocorrências de Conophyton no Grupo Itaiacoca na região de Abapã

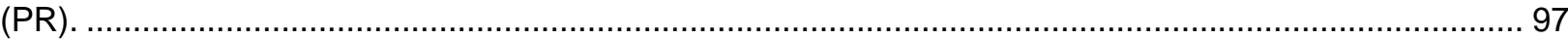

Figura 43: Zona axial e seu respectivo traço axial na amostra CABA-03 (Est. XIV-A)...........................98

Figura 44: Freqüência relativa das lâminas escuras (L2) e claras (L1) da amostra CABA-03, Abapã, PR. $\mathrm{N}=55$ (L2) e 52 (L1).

Figura 45: Desenho da laminação elaborado a partir de fotografia de lâmina petrográfica da amostra CABA-

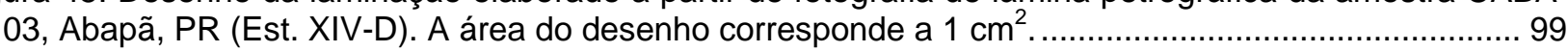

Figura 46: Mapa de localização de algumas ocorrências de Conophyton no Grupo Paranoá em Minas Gerais e Goiás. 
Figura 47: Freqüência relativa das lâminas escuras (L2) e claras (L1) da amostra CPAR-05. N=105 (L2) e

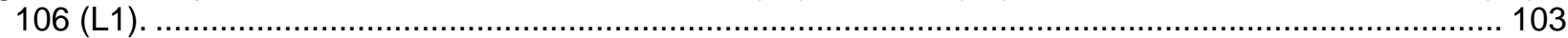

Figura 48: Detalhes das zonas axiais e traços axiais em amostras do Grupo Paranoá. A- Amostra CPAR-05 (Est. XV-A); B e C- Amostra CPAR-07 (Est. XV-E e F); D e E- Amostra CPAR-06 (Est. XVI-A e B); F e GAmostra CPAR-10 (Est. XVI-E)........................................................................................ 104

Figura 49: Desenho da laminação elaborado a partir de fotografia de lâmina petrográfica da amostra CPAR05 (Est. XV-D). As partes em cinza correspondem as porções recristalizadas. A área representada corresponde a $1 \mathrm{~cm}^{2}$.

Figura 50: Freqüência relativa das lâminas escuras (L2) e claras (L1) da amostra CPAR-07. N=53 (L2) e 52 (L1).

Figura 51: Laminação de Conophyton metulum, elaborado a partir de fotografia de lâmina petrográfica da

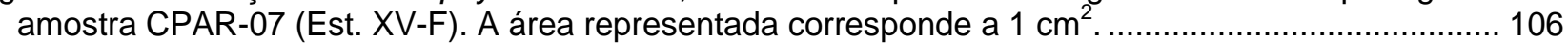

Figura 52: Freqüência relativa das lâminas escuras (L2) e claras (L1) da amostra CPAR-06. N=99 (L2) e 102 (L1).

Figura 53: Freqüência relativa das lâminas escuras (L2) e claras (L1) da amostra CPAR-10. N=54 (L2 e L1).

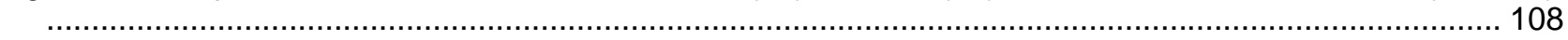

Figura 54: Desenho da laminação elaborado a partir de fotografia de lâmina petrográfica da amostra CPAR-

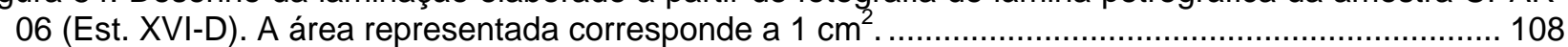

Figura 55: Relações entre os bioermas e suas respectivas formas, em um ambiente de rampa (modificado de Grotzinger, 1989)......

113

Figura 56: Comparação das freqüências relativas das lâminas escuras (L2) e claras (L1) das amostras LAV32 (Itapeva) e CABA-03 (Abapã). Para LAV-32, N=106 (L2) e 107 (L1) e para CABA-03, N=55 (L2) e 52 (L1).

Figura 57: Comparação das freqüências relativas das lâminas escuras (L2) e claras (L1) das amostras de Cabeludo (CPAR-05), Cabeceiras (CPAR-06 e 10) e Lagamar (CPAR-07). Para CPAR-05, N=105 (L2) e 106 (L1); CPAR-06, N=99 (L2) e 102 (L1); CPAR-07, N=53 (L2) e 52 (L1) e CPAR-10, N=54 (L2 e L1).

Figura 58: Comparação das freqüências relativas das lâminas escuras (L2) e claras (L1) das amostras de Itapeva (LAV-32), Cabeludo (CPAR-05) e Cabeceiras (CPAR-06). Para LAV-32, N=106 (L2) e 107 (L1); CPAR-05, N=105 (L2) e 106 (L1) e CPAR-06, N=99 (L2) e 102 (L1)..... 118

\section{ÍNDICE DE TABELAS}

Tabela 1: Principais litotipos do Grupo Itaiacoca mapeados por Theodorovicz et al. $(1986 ; 1988)$ na região de Itapeva e suas filiações. A unidade A corresponde a base da sequência.............................................. 5 Tabela 2: Correlações sugerida entre as unidades descritas. ........................................................... 10 Tabela 3: Idades radiométricas obtidas por Reis Neto (1994) para o Grupo Itaiacoca no Estado do Paraná.

Tabela 4: Situação dos afloramentos descritos, com as siglas adotadas e seus respectivos números de

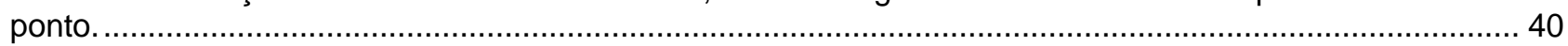

Tabela 5: Modo de ocorrência dos estromatólitos na área de estudo. .................................................... 53

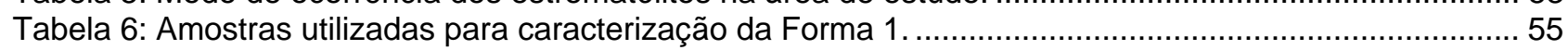

Tabela 7: Dados utilizados para morfometria na Forma 1.................................................................... 55

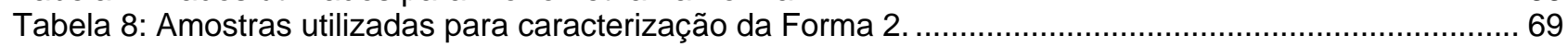

Tabela 9: Dados utilizados para morfometria na Forma 2 .................................................................. 69

Tabela 10: Amostras utilizadas para caracterização da Forma 3. ........................................................... 76

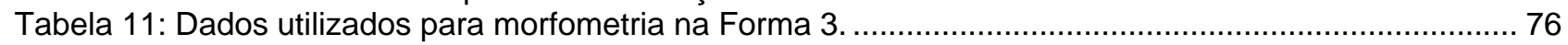

Tabela 12: Medidas (em $\mathrm{cm} ; \mathrm{N}=58$ ) dos eixos maior e menor de colunas de estromatólitos em corte transversal de IND, com os cálculos de diâmetro, $R_{f}$ e $R_{s}$. 1- medidas em amostras; 2- medidas de campo; 3- medidas em fotografia (Est. XIII-G) ...................................................................................... 90 Tabela 13: Medidas (em cm; $\mathrm{N}=50$ ) de eixo maior e menor para oólitos da região de Bom Sucesso de

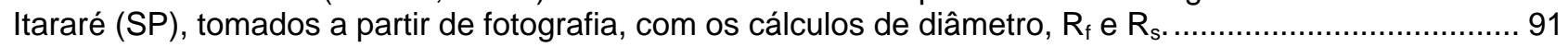

\section{ANEXOS}

Anexo 1: Coordenadas UTM das ocorrências de estromatólitos................................................................... a

Anexo 2: Coleções do Instituto Geológico (Coleção Sérgio Mezzalira) ...................................................... b

Anexo 3: Coleções do Laboratório de Paleontologia Sistemática - GSA, IG/USP. ......................................

Anexo 4: Amostras utilizadas para comparação. ...............................................................................

Anexo 5: Amostras utilizadas na caracterização das formas e seus números de coleção (Coleção do Laboratório de Paleontologia Sistemática - GSA, IG/USP... 


\section{INTRODUÇÃO}

Estromatólitos são estruturas biossedimentares originadas por atividade microbiana que ocorrem desde o Arqueano até hoje, sendo mais abundantes nas sequências carbonáticas proterozóicas. No Brasil ocorrem em diversas unidades proterozóicas, principalmente no Cráton do São Francisco e nas faixas dobradas associadas a este cráton, bem como nas faixas Paraguai e Ribeira.

São utilizados para determinação de antigas linhas de costa, interpretações paleogeográficas e paleoambientais, determinação de topo e base de sequências dobradas, correlações e mais raramente bioestratigrafia. No Brasil este potencial de uso dos estromatólitos ainda foi pouco explorado, podendo ainda fornecer bons resultados.

Na Faixa Ribeira, nos estados de São Paulo e Paraná, ocorrem seis unidades carbonáticas, de provável idade mesoproterozóica superior a neoproterozóica inferior, separadas tectonicamente. Três dentre estas seis unidades contêm estromatólitos, que são o Grupo Itaiacoca e as formações Água Clara e Capiru. Em especial no Grupo Itaiacoca, uma sequência vulcanossedimentar cujos carbonatos estromatolíticos foram objeto deste estudo, o uso dos estromatólitos pode ser importante pois apesar desta unidade ter sido objeto de alguns estudos anteriores (Almeida, 1944, 1957; Fairchild, 1977), necessita ainda de uma melhor caracterização paleoambiental e paleogeográfica, bem como de correlações entre as diversas unidades carbonáticas. Parte destes aspectos serão abordados neste trabalho.

\subsection{Objetivos}

Especificamente, os objetivos deste projeto são:

1) Caracterizar a morfologia, modo de ocorrência e a morfogênese das diversas formas de estromatólitos na região ao sul de Itapeva (SP);

2) Detalhar o contexto estratigráfico e estrutural local destas ocorrências;

3) Interpretar o ambiente de deposição e a paleogeografia dos corpos estromatolíticos investigados;

4) Comparar os estromatólitos coniformes de Itapeva com outros na Faixa Itaiacoca no estado do Paraná, e, depois, com formas semelhantes na Faixa Brasília (Moeri, 1972; Cloud \& Dardenne, 1973; Dardenne \& Campos Neto, 1976). 
Através disto pode-se obter dados para auxiliar a compreensão dos ambientes de deposição e paleogeografia do Grupo Itaiacoca, bem como subsídios para correlação da área estudada com outros locais.

\section{2. Área de estudo}

A área do estudo localiza-se a sul da cidade de Itapeva (Folha Ribeirão Branco SG. 22 - X - B - II - 1, escala 1:50.000), no sul do estado de São Paulo, a cerca de 350 km da capital (Figura 1).

O acesso é feito pela rodovia Pres. Castelo Branco (SP-280) até Tatuí, tomando-se a rodovia SP-127 até Capão Bonito, e, depois a rodovia SP-258 até Itapeva (Figura 1). Na área estudada existem três estradas de asfalto principais que ligam Itapeva, respectivamente, a Ribeirão Branco (SP-249), a Nova Campina (antiga Campina do Veado) e a Itararé (SP-258), além de várias estradas secundárias não pavimentadas. 


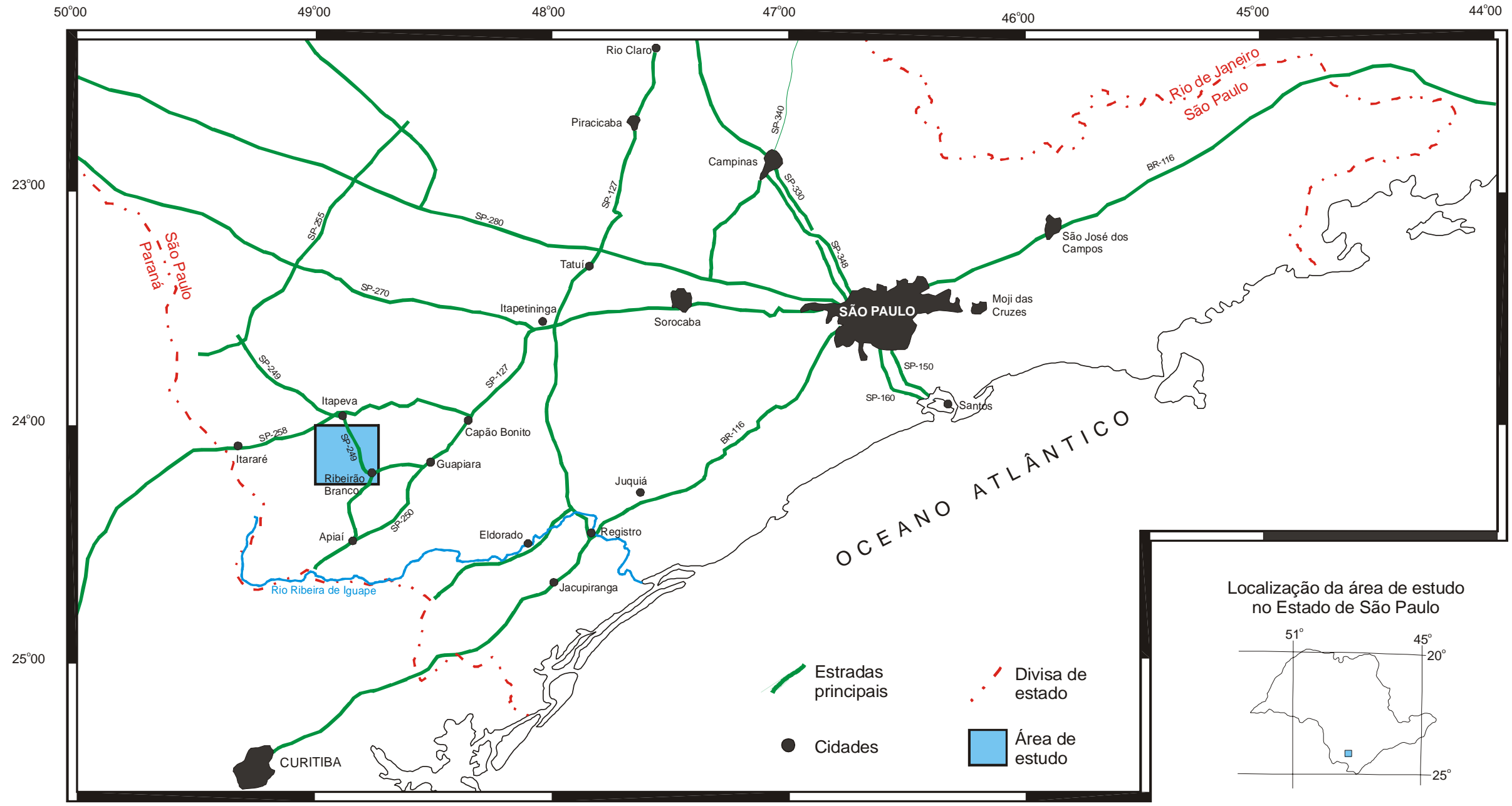

Figura 1: Mapa de localização e acessos (Fonte: Guia Quatro Rodas, 1994). 


\section{GEOLOGIA REGIONAL}

F.F.M. de Almeida descreveu pela primeira vez, em 1944, estromatólitos no Brasil, e posteriormente (Almeida, 1957), encontrou diversas outras ocorrências de estromatólitos na faixa de carbonatos que estende-se desde Itapeva (SP) até Itaiacoca $(P R)$, que ele denominou de "Formação Itaiacoca" e inseriu na "Série" Açungui.

O Grupo Itaiacoca, como é atualmente denominado, se estende NE-SW desde a região entre Guapiara e Itapeva (SP) até Itaiacoca (PR), compondo cerca de $200 \mathrm{~km}$ de extensão e em média $20 \mathrm{~km}$ de largura. Seus limites NW e SE se dão com o Complexo Graníticos Cunhaporanga e Três Córregos (Neoproterozóico superior-Eopaleozóico), respectivamente. Os sedimentos paleozóicos da Formação Furnas e do Subgrupo Itararé, da Bacia do Paraná, recobrem, em discordância angular e erosiva, os extremos NE e SW do Grupo Itaiacoca, bem como parte do limite NW, principalmente no estado de São Paulo (Figura 2; Est. I-A).

Originalmente inserido na "Faixa de Dobramentos Apiaí" do "Cinturão de Dobramentos Ribeira" (Hasui et al., 1975) ou "Região de Dobramentos Sudeste" (Almeida et al.,1976), o Grupo Itaiacoca tem sido destacado, mais recentemente, como pertencente a uma faixa mais a NW, denominada "Faixa Itapeva" por Hasui et al. (1984), ou "Faixa Itaiacoca-Itapeva" por Chiodi Filho (1984), separada da Faixa Apiaí. Reis Neto (1994) definiu a Faixa Itaiacoca de forma mais ampla, como "todas as rochas compreendidas entre os Complexos graníticos Três Córregos e Cunhaporanga". Isto englobaria o Grupo Itaiacoca, a Formação Água Clara e o Complexo Apiaí-Mirim.

Assim, o Grupo Itaiacoca seria distinto e independente do Grupo Açungui, também portador de carbonatos estromatolíticos (Bigarella \& Salamuni, 1958; Marini et al,1967; Marini \& Bósio, 1971; Fairchild, 1977, 1982), que aflora mais a SE, dentro da Faixa Apiaí, ambos inseridos no Cinturão ou Faixa Ribeira.

O Grupo Itaiacoca sempre foi distinguido como uma unidade predominantemente carbonática, mas pesquisas na década de 80 demonstraram maior variedade litológica. Por exemplo, Trein et al. (1985), na região de Abapã (PR), distinguiram no Grupo Itaiacoca duas sequências distintas:

1) Sequência Abapã, na base, uma sucessão metavulcanossedimentar composta de metarcósios, metarenitos, basaltos, basaltos andesíticos, tufos de composição intermediária e, raramente, rochas ácidas. Nas lavas e nos tufos ocorrem vesículas e amígdalas. 
2) Sequência carbonática, no topo, uma sucessão metassedimentar de metassiltitos e quartzitos (metarenitos), recobertos por metadolomitos, em contato brusco com a Sequência Abapã.

Já no estado de São Paulo, em mapeamento na escala 1:50.000 ao sul de Itapeva (Figura 3), Theodorovicz et al. (1986, 1988) confirmaram a presença desta associação metavulcanossedimentar e elevaram a Formação Itaiacoca ao status de grupo, subdividindo-o em três unidades, conforme resumido na Tabela 1. Ao contrário de Trein et al. (1985), Theodorovicz et al. $(1986,1988)$ demonstraram interdigitação entre as unidades na região de Itapeva (Figura 4).

\begin{tabular}{|c|c|c|c|c|c|}
\hline \multirow{2}{*}{$\begin{array}{l}\mathrm{U} \\
\mathrm{N} \\
\mathrm{I} \\
\mathrm{D}\end{array}$} & \multirow[t]{2}{*}{ Litotipos } & \multicolumn{4}{|c|}{ Filiação } \\
\hline & & Vulcânica & $\begin{array}{l}\text { Vulcanos- } \\
\text { sedimentar }\end{array}$ & $\begin{array}{l}\text { Sedimentar } \\
\text { terrígena }\end{array}$ & $\begin{array}{l}\text { Sedimentar } \\
\text { química }\end{array}$ \\
\hline \multirow{5}{*}{ c } & Metapelitos & & & & \\
\hline & Metarritmitos & & & & \\
\hline & Metachert & & & & \\
\hline & Metacalcários & & & & \\
\hline & Filitos & & & & \\
\hline \multirow[t]{2}{*}{ B } & $\begin{array}{l}\text { Metavulcanitos de ascendência básica, ultrabásica a } \\
\text { intermediária, xistificados ou não, compostos por } \\
\text { metabasaltos, metadiabásios, metagabros, } \\
\text { metapiroxenitos e metadacitos-andesitos }\end{array}$ & & & & \\
\hline & $\begin{array}{l}\text { Clorita-xistos, talco-xistos, metacalcários, } \\
\text { metaconglomerados polimíticos, quartzo-clorita } \\
\text { xistos e metatufos de provável ascendência } \\
\text { máfica/ultramáfica }\end{array}$ & & & & \\
\hline \multirow{8}{*}{ A } & $\begin{array}{l}\text { Metaconglomerado oligomítico, quartzitos impuros e } \\
\text { quartzo-xisto }\end{array}$ & & & & \\
\hline & Quartzitos & & & & \\
\hline & $\begin{array}{l}\text { Metarenitos impuros, localmente conglomeráticos e } \\
\text { com interdigitações subordinadas de clorita-xistos e } \\
\text { rochas de ascendência vulcânica }\end{array}$ & & & & \\
\hline & $\begin{array}{l}\text { Metarenitos arcoseanos com metavulcanitos } \\
\text { xistificados ou não, subordinados }\end{array}$ & & & & \\
\hline & Metarenitos, quartzo-muscovita-xistos e metabasitos. & & & & \\
\hline & $\begin{array}{l}\text { Metassedimentos areno-argilosos carbonáticos, } \\
\text { filitos carbonosos }\end{array}$ & & & & \\
\hline & Metacalcário carbonoso & & & & \\
\hline & $\begin{array}{l}\text { Metarenitos com intercalações subordinadas de } \\
\text { xistos verdes e quartzitos }\end{array}$ & & & & \\
\hline
\end{tabular}

Tabela 1: Principais litotipos do Grupo Itaiacoca mapeados por Theodorovicz et al. $(1986 ; 1988)$ na região de Itapeva e suas filiações. A unidade $A$ corresponde a base da sequência. 


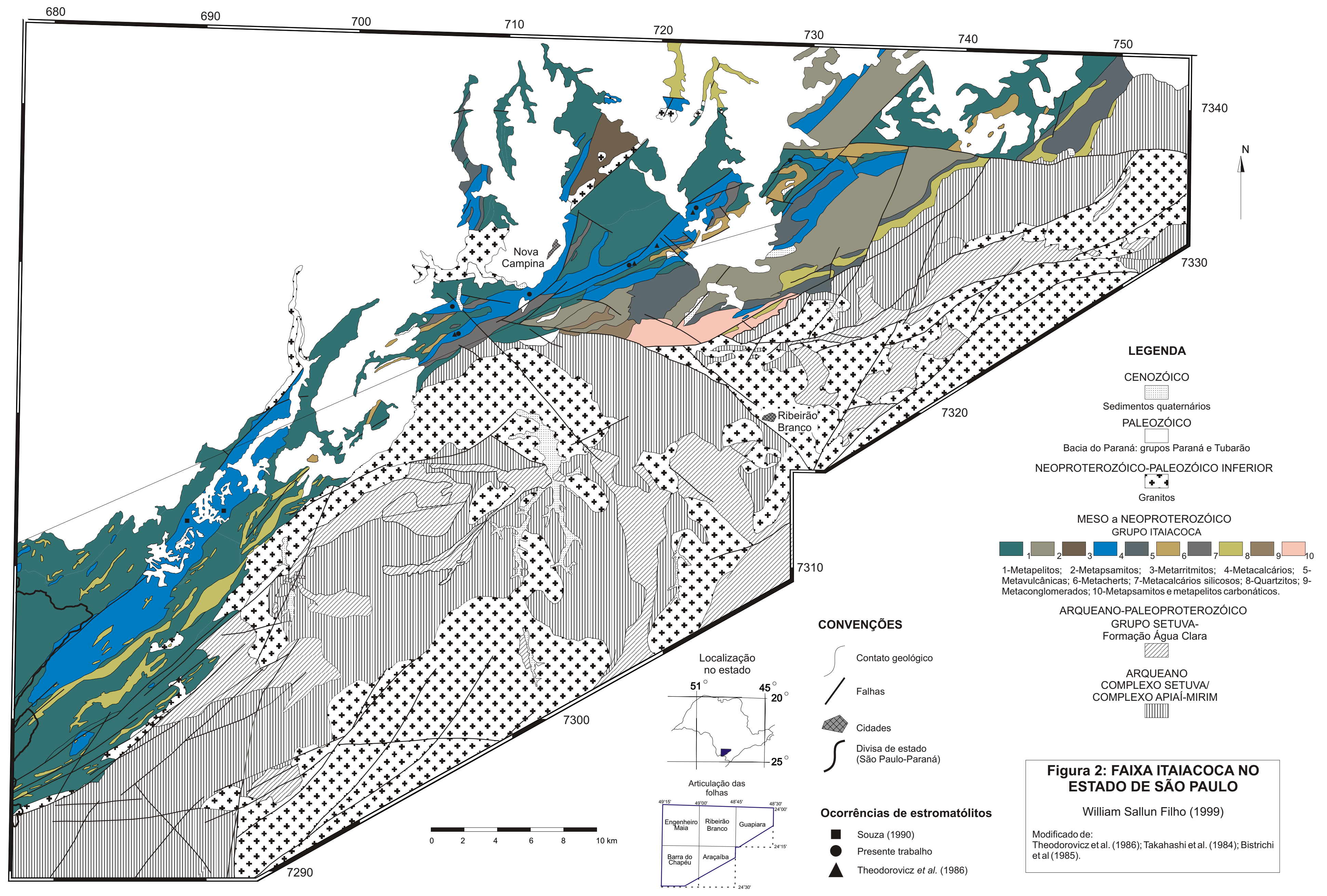



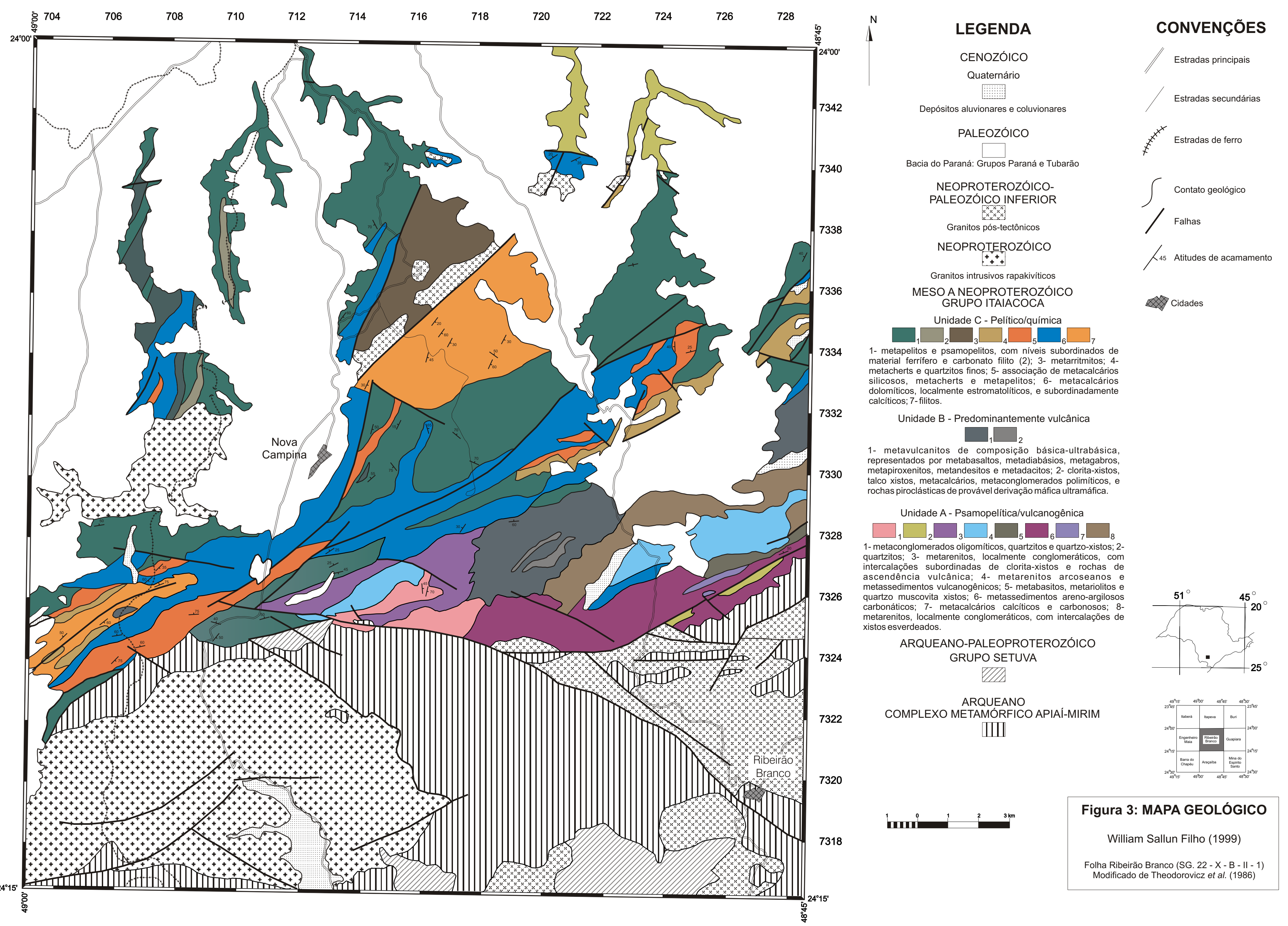


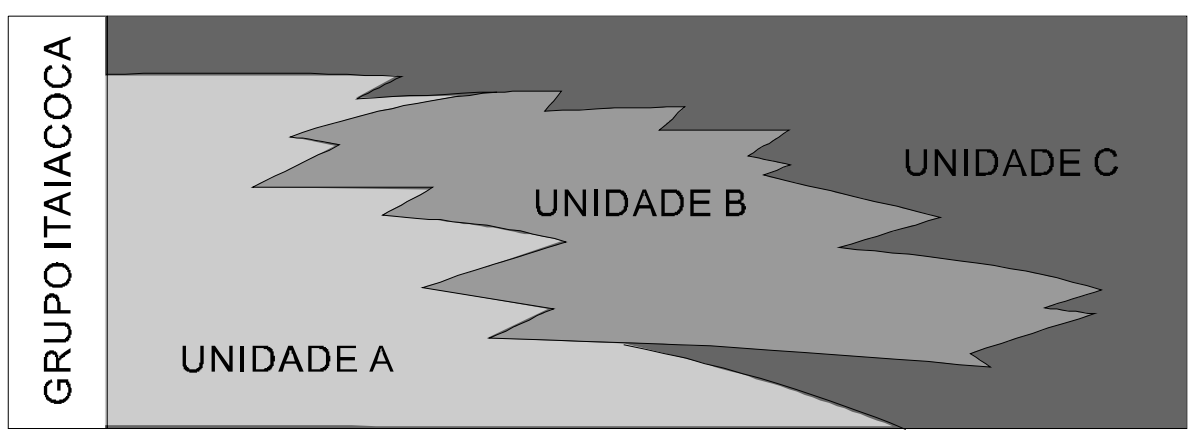

Figura 4: Relações estratigráficas no Grupo Itaiacoca segundo Theodorovicz et al. (1986).

Os estudos foram concentrados principalmente na Unidade $C$, mas também foram descritos afloramentos nas unidades B e C. Na Unidade C observaram-se metapelitos em grande parte da área (Pontos 15, 41 e 55), bastante deformados (Est. I-B e C), e apresentando grande variedade de tipos, desde maciços a bandados, pouco foliados até filitos (Pontos 8, 30 e 39). Os metacherts, também comuns, ocorrem nos pontos 3, 5, 6, 25 e 34, sustentando altos topográficos como cristas de serras alongadas (Est. I-D e E). São compostos quase que totalmente por sílica (quartzo), de coloração branca. Ocorrem também metacherts verdes e vermelhos, sendo que estes últimos possuem películas de óxido de ferro entre os grãos de quartzo. Estes metacherts estão bastante recristalizados, não apresentando estratificação ou outra estrutura reliquiar.

Por fim, distinguiram-se tipos distintos de metacalcários dolomíticos e calcíticos na Unidade C, que ocupam uma porção expressiva da área:

- dolomíticos cinza claros estromatolíticos (Pontos 2, 11, 16, 19, 27 e 35);

- dolomíticos cinza claros estratificados (Pontos 1, 26, 32, 33, 51, 53 e 54) (Est. l$\mathrm{F})$;

- dolomíticos cinza claros maciços (Pontos 4, 36, 37 e 54);

- dolomíticos estratificados parcialmente silicificados (Pontos 12, 13, 18 e 31);

- dolomíticos estromatolíticos silicificados (Ponto 31);

- dolomíticos avermelhados estromatolíticos (Ponto 17);

- calcíticos cinza escuros estromatolíticos (Pontos 9 e 44);

- calcíticos cinza escuros estratificados (Pontos 7 e 38);

- dolomíticos/calcíticos intensamente deformados ("mármores") (Ponto 43);

- dolomíticos/calcíticos intercalados com metapelitos (Pontos 45, 46, 48 e 52).

Os contatos dos metacalcários com os metapelitos são difíceis de se observar, mas em alguns pontos os metacalcários apresentam contato gradual com metapelitos 
sobrepostos (Pontos 07 e 09). Já o contato inferior com os metacherts não foi observado, sendo inferido.

Na mesma faixa, ao redor de Bom Sucesso de Itararé (SP) na divisa dos estados de São Paulo e Paraná, Souza (1990) subdividiu o Grupo Itaiacoca em quatro formações, da base para o topo:

- Formação Bairro da Estiva: metaconglomerados, metarenitos;

- Formação Água Nova: metapelitos, metacalcários;

- Formação Serra do Macaco: metarenitos, quartzitos;

- Formação Bairro dos Campos: metadolomitos, metarenitos, metapelitos.

$\mathrm{Na}$ área estudada por Souza (1990), praticamente não ocorrem rochas metavulcânicas, como mais a sul, na região de Abapã e a norte, na região de Itapeva.

Reis Neto (1994), baseado em mapeamento na escala de 1:50.000 na região de Itaiacoca-Abapã-Socavão (PR), definiu uma sequência semelhante, utilizando parte do esquema de Souza (1990), ou seja, da base para o topo:

- Formação Abapã: metarenitos, metarcósios, metavulcânicas;

- Formação Água Clara: calcio-silicatadas;

- Formação Serra do Macaco: quartzitos, metapelitos;

- Formação Bairro dos Campos: metadolomitos, metapelitos, metarenitos.

Nesta proposta Reis Neto (1994) compara as formações Abapã e Água Clara com as formações Bairro da Estiva e Água Nova (Souza, 1990), respectivamente, estabelecendo semelhanças litológicas. Coloca, ainda, a Formação Água Clara, considerada independente, como parte integrante da Grupo Itaiacoca, com base em semelhanças litológicas.

Mais recentemente, Prazeres Filho et al. (1998) retomaram o mapeamento do Grupo Itaiacoca, na escala de 1:50.000, entre Abapã e Socavão (PR), na mesma área estudada por Reis Neto (1994), e identificaram da base para o topo, unidade metarcoseana/metavulcânica, unidade metacarbonática e unidade metapelítica, sem, no entanto, adotar a terminologia de nenhum dos esquemas litoestratigráficos previamente propostos.

Embora seja difícil estabelecer uma estratigrafia fina para o grupo devido às complicações estruturais, grande variação lateral de fácies e poucos elementos específicos em comum entre as regiões (inclusive ausência de fósseis morfologicamente distintos, exceção feita talvez à presença de estromatólitos coniformes em diversos lugares ao sul de Itapeva e na região de Abapã), pode-se reconhecer uma sucessão 
estratigráfica geral para o Grupo Itaiacoca, evidente nos diversos trabalhos (Trein et al., 1985; Theodorovicz et al., 1986; Souza, 1990; Reis Neto, 1994; Prazeres Filho et al., 1998), que se inicia com uma associação vulcanossedimentar (bastante variada), seguida por uma química/pelítica (Tabela 2).

\begin{tabular}{|l|c|c|c|c|}
\hline REGIÃO & Abapã (PR) & Itapeva (SP) & Bom Sucesso (SP) & Abapã (PR) \\
\hline AUTOR & Trein et al. (1985) & Theodorovicz et al. (1986) & Souza (1990) & Reis Neto (1994) \\
\hline UNIDADES & Sequência & Unidade C & Bairro dos Campos & Bairro dos Campos \\
\cline { 3 - 4 } & Carbonática & & Serra do Macaco & Serra do Macaco \\
\cline { 2 - 4 } & Sequência Abapã & Unidade B & Abapã \\
\cline { 3 - 4 } & & Unidade A & Bairro da Estiva & \\
\hline
\end{tabular}

Tabela 2: Correlações sugerida entre as unidades descritas.

Evidente, no início do desenvolvimento da bacia houve intenso vulcanismo e soerguimento da área fonte, depositando-se as sequências metavulcânicas e metassedimentares essencialmente terrígenas, em ambiente tectonicamente ativo, provavelmente de rift (Trein et al., 1985; Souza, 1990; Reis Neto, 1994). Uma fase posterior, mais estável, propiciou extensa sedimentação de plataforma carbonática e terrígena.

O único estudo sedimentológico mais pormenorizado do Grupo Itaiacoca foi o de Petri \& Suguio em 1969. Segundo estes autores os calcários ao sul de Itapeva (na Unidade C) se depositaram em ambiente plataformal de clima quente, compreendendo grandes lentes dentro dos arenitos. Na região de Bom Sucesso (SP), Hachiro et al. (1992) interpretaram metacalcários oolíticos como barras supostamente associadas a recifes estromatolíticos de mar aberto depositadas em plataforma costeira. Faltam, ainda, estudos e interpretações desse tipo referentes às rochas siliciclásticas.

O contexto tectônico da Faixo Ribeira que propiciou a deposição do Grupo Itaiacoca, segundo Campanha \& Sadowski (1998), envolveu rifteamento e abertura oceânica, formação de arco de ilhas e colisão de um bloco continental contra o arco de ilhas, ou alternativamente, abertura e fechamento de uma bacia marginal de retro-arco.

A idade da sedimentação na região foi primeiramente proposta para o Grupo Açungui (senso lato) como algo em torno de 650 Ma ou mais, através do método K-Ar em rochas metamórficas e granitóides associados (Cordani \& Bittencourt, 1967a; 1967b). Cordani \& Kawashita (1971) obtiveram a idade de 608 $\pm 48 \mathrm{Ma}$, pelo método Rb-Sr para granitos intrusivos, mas estes números retratam apenas idades brasilianas de 
metamorfismo e de intrusões graníticas, e não podem ser consideradas a idade da deposição do grupo.

As idades mais recentes obtidas para o Grupo Itaiacoca são as de Reis Neto (1994), utilizando vários métodos em vários tipos de rochas, como mostra a Tabela 3.

\begin{tabular}{|l|c|c|c|c|c|}
\cline { 2 - 5 } \multicolumn{1}{c|}{} & \multirow{2}{c|}{ Rocha } & \multicolumn{3}{c|}{ Método e idades (Ma) } & \multirow{2}{*}{ Idades (Ma) } \\
\cline { 3 - 5 } \multicolumn{1}{c|}{} & & $\mathrm{Pb}-\mathrm{Pb}$ & $\mathrm{Rb}-\mathrm{Sr}$ & $\mathrm{Sm}-\mathrm{Nd}$ & \\
\hline Formação Abapã & Metavulcânica & $1706 \pm 319$ & $\begin{array}{c}1086 \pm 147 \\
1382 \pm 47\end{array}$ & $909 \pm 77$ & $1250 \pm 100$ \\
\hline \multirow{2}{*}{$\begin{array}{l}\text { Formação Bairro } \\
\text { dos Campos }\end{array}$} & Metadolerito & $1083 \pm 252$ & $1036 \pm 122$ & 1797 & 1080 \\
\cline { 2 - 5 } & Metacalcário & $1123 \pm 350$ & - & - & 1123 \\
\hline
\end{tabular}

Tabela 3: Idades radiométricas obtidas por Reis Neto (1994) para o Grupo Itaiacoca no Estado do Paraná.

Através da correlação preliminar de alguns dos estromatólitos da região de Itapeva e C. garganicum, relativamente comum mundialmente no Proterozóico, Fairchild (1977) sugeriu, tentativamente, que os carbonatos do Grupo Itaiacoca poderiam ter uma idade entre 850 e $1700 \mathrm{Ma}$.

Embora não se tenha uma idade precisa para a sedimentação do Grupo Itaiacoca, as evidências disponíveis apontam para a parte final do Mesoproterozóico ou, possivelmente, início do Neoproterozóico.

As complicações da estratigrafia e da idade de sedimentação do Grupo Itaiacoca refletem, em grande parte, a complexidade estrutural da região. Primeiramente, o arcabouço estrutural do Grupo Itaiacoca exibe uma forte orientação NE-SW, com grandes dobras abertas nos pacotes carbonáticos e quartzíticos, e dobras cerradas a isoclinais nos pacotes menos competentes, exibindo vergência estrutural para NW (Campanha et al., 1987). O metamorfismo gerado foi de grau xisto verde incipiente a baixo (Trein et al., 1985; Campanha et al., 1987). A deformação e o metamorfismo teriam sido gerados no Neoproterozóico, quando esta região comportou-se como um arco magmático continental (Reis Neto, 1994; Campanha \& Sadowski, 1998).

Posteriormente aos eventos deformacionais e metamórficos principais, no final do Neoproterozóico e início do Paleozóico (Campanha \& Sadowski, 1998), diversas falhas e zonas de cisalhamento de direção geral NE-SW e de caráter essencialmente transcorrente afetaram toda a área do Pré-Cambriano de São Paulo e Paraná, inclusive o Grupo Itaiacoca. Estas falhas podem apresentar rejeitos quilométricos, tornaram tectônicos muitos dos contatos originais, dificultando ainda mais as reconstituições 
paleogeográficas (Campanha et al., 1987), e possivelmente geraram uma série de terrenos distintos (Campanha \& Sadowski, 1998) (Figuras 2, 3 e 17). 
ESTAMPA I

A - Sedimentos paleozóicos da Bacia do Paraná em discordância angular com filitos brancos. Ponto 8, pedreira.

B, C - Pedreira de filitos. B - Metapelitos exibindo dobramento sinclinal; C -Detalhe da fotografia B, mostrando metapelitos estratificados. A escala no centro da foto corresponde a $13 \mathrm{~cm}$. Ponto 15.

D - Crista formada por metacherts. "Serrinha", região do Alto da Brancal.

E - Pedreira de metacherts. Ponto 25.

F - Pedreira Lavrinhas. Metacalcários estratificados. Ponto 01. 

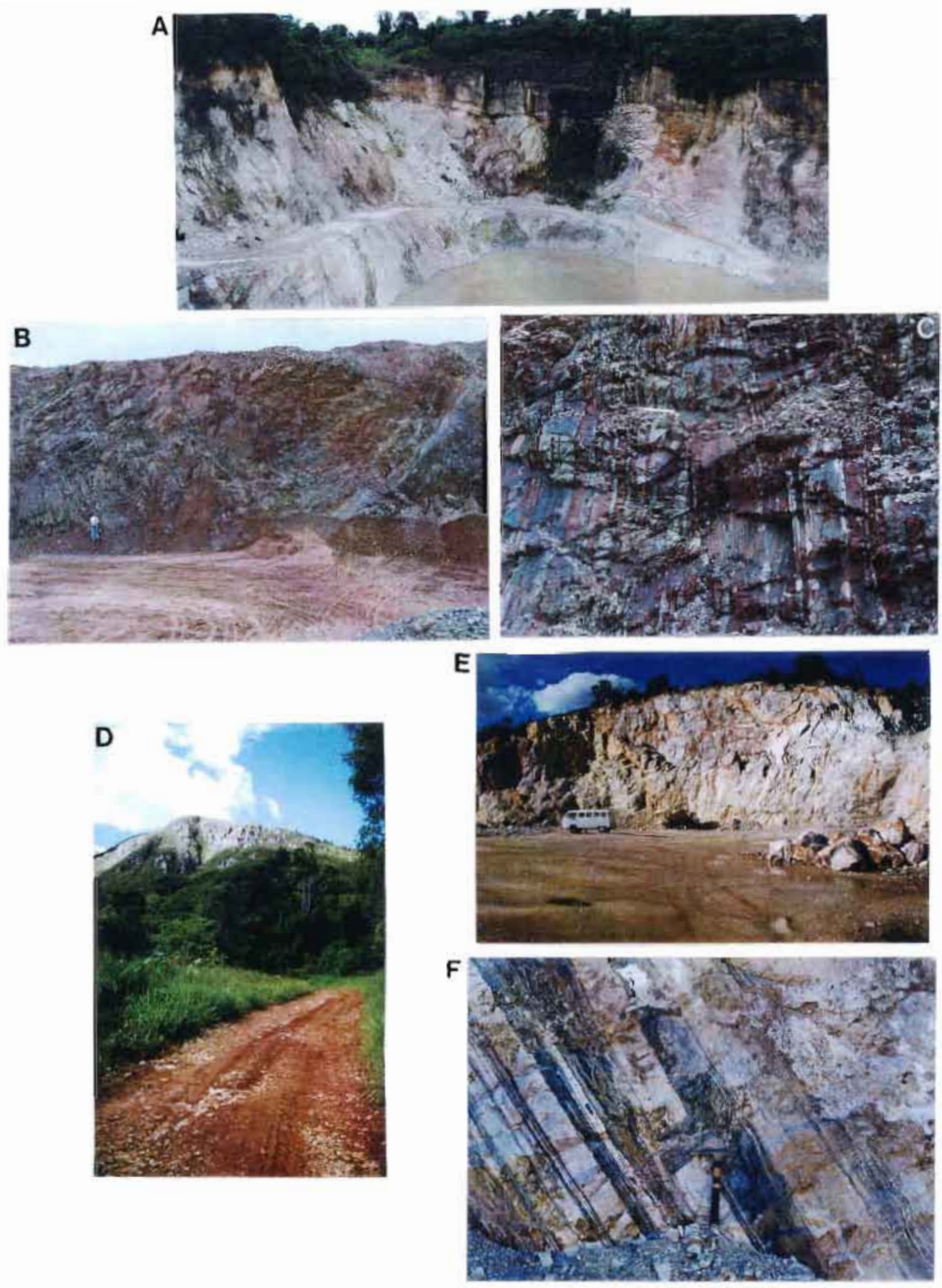


\section{ESTROMATÓLITOS}

\subsection{Conceitos gerais}

O estudo dos estromatólitos teve origem no século passado com interpretações que reconheciam seu caráter biológico mas desconheciam suas afinidades (Hofmann,1973). Foi a partir da década de 30 que o estudo dos estromatólitos começou a se desenvolver mais intensamente, e nas décadas de 60 e 70 teve seu auge em decorrência das tentativas de utilizá-los tanto para correlação e datações do PréCambriano como para interpretações sedimentológicas e paleogeográficas (Hofmann, 1973). Uma vez que estromatólitos se formam por processos biológicos e sedimentológicos, seu estudo tem afinidades com a paleontologia e a sedimentologia, conforme se vê na Figura 5 (Hofmann, 1973).

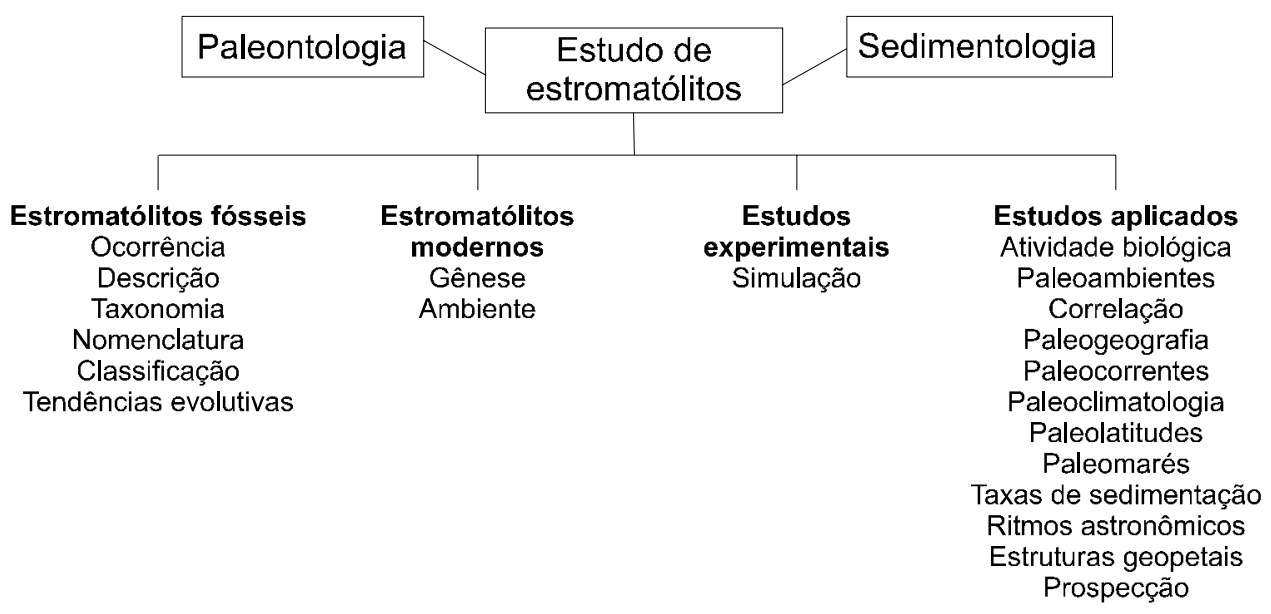

Figura 5: Relações do estudo de estromatólitos e suas aplicações (Hofmann,1973).

O termo estromatólito foi empregado primeiramente em 1908 por Kalkowsky (apud Walter, 1976). Durante vários anos, houve certa confusão no seu uso, e tal como sua definição original, algumas outras definições enfatizaram aspectos descritivos como "estruturas biossedimentares laminadas" (Hofmann, 1973) ou, simplesmente, "rochas laminadas" (Krumbein, 1983). Mas para formas externamente idênticas mas internamente não laminadas (trombólitos) sua aplicação é difícil.

Atualmente, os estromatólitos são tidos como estruturas biossedimentares produzidas por uma mescla de processos sedimentológicos e biológicos, resultantes da interação de comunidades microbianas bentônicas (principalmente, de cianobactérias e bactérias) com o meio em que vivem (Hofmann, 1969; Walter, 1976; Burne \& Moore, 
1987). Esta definição genética, tem se mostrado mais adequada, do que uma definição meramente descritiva, pois a idéia de que estas estruturas se tratam de evidências de atividades biológicas pretéritas (sendo, portanto, fósseis) é muito enraizada na literatura geológica. Estromatólitos não são fósseis no sentido mais comum deste termo, por serem estruturas biossedimentares resultantes da atividade de comunidades microbianas (Walter, 1977), são na verdade icnofósseis. Definitivamente, não são "algas fósseis", como aparece, erradamente, em muitos trabalhos antigos. Aceito este conceito de estromatólito, outras estruturas semelhantes, como espeleotemas (Thrailkill, 1976) e diversas outras incrustações minerálicas, poderiam ser classificadas no máximo (mas de maneira contraditória) como "estromatólitos inorgânicos". Assim, o estudo da gênese de estromatólitos fósseis tem sido baseado em seus correspondentes atuais. Em quase todas as unidades carbonáticas proterozóicas ocorrem estromatólitos, mas também foram registrados em fosforitos, formações bandadas de ferro e raramente em arenitos (Walter et al., 1992).

Burne \& Moore (1987) propuseram o termo microbialito para depósitos biossedimentares formados pela interação entre comunidades microbianas bentônicas e sedimentos. Identificaram três tipos de estrutura interna:

- estrutura estromatolítica: textura finamente laminada (não concêntrica);

- estrutura trombolítica: textura não laminada com aspecto de coágulo (clots em inglês);

- estrutura oncolítica: textura concêntrica finamente laminada.

Desta forma, Burne \& Moore (1987) consideraram um estromatólito como um microbialito estromatolítico; um trombólito como um microbialito trombolítico; e um oncólito como um microbialito oncolítico. Mas esta terminologia não tem sido muito aplicada, devido ao termo estromatólito já ser consagrado na literatura. Walter (1992), por exemplo, considera o termo estromatólito (incluindo os trombólitos e os oncólitos) como sinônimo de microbialito.

Os estromatólitos são formados pela ação de organismos fotossintetisantes que agregam e/ou induzem a precipitação de minerais, que se acumulam sucessivamente (Golubic, 1976a). Algumas condições básicas para seu desenvolvimento incluem uma população de organismos bentônicos (p. ex. cianobactérias) que colonizam o substrato, substrato em que a microbiota possa crescer, água, nutrientes, uma fonte de energia ( $p$. ex. luz solar), grãos minerais suficientemente finos para que possam ser aglutinados, entre outros (Hofmann, 1973). Os organismos construtores de estromatólitos atuais 
incluem uma grande variedade de cianobactérias, algas eucarióticas, bactérias fotossintetisantes e bactérias heterotróficas, formando comunidades complexas (Golubic, 1976b).

Os microorganismos observados nas esteiras superficiais de estromatólitos modernos podem contribuir ativa ou passivamente para sua construção ou destruição (Golubic, 1976a). Nestas comunidades vivas, Burne \& Moore (1987) identificaram três processos principais que, contribuem juntos, em maior ou menor grau, na formação do estromatólito (Figura 6).

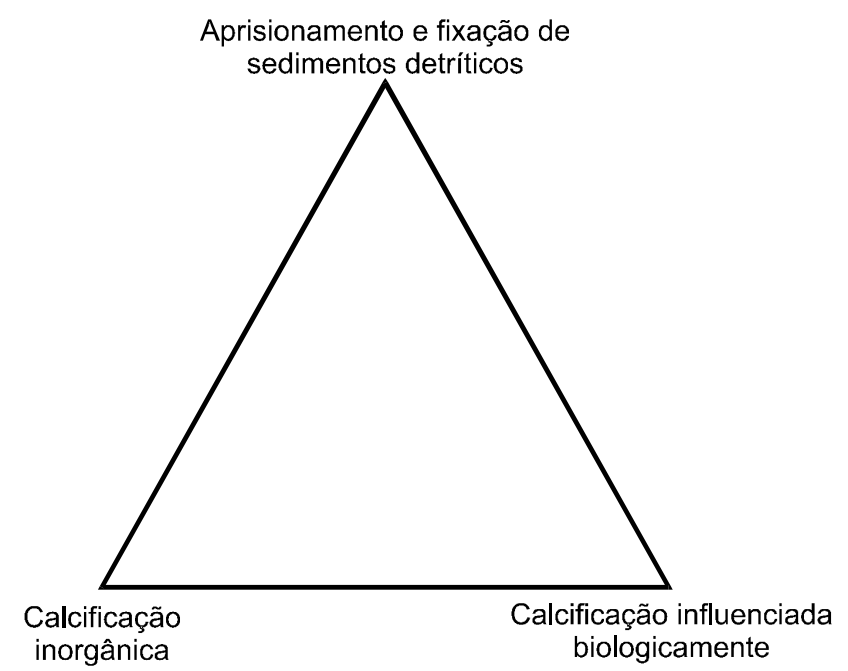

Figura 6: Gráfico triangular de Burne \& Moore (1987) ilustrando os três processos principais de formação dos estromatólitos.

Segundo estes autores a construção de um estromatólito é dada basicamente pelo aprisionamento e fixação de sedimentos, ocasionado pela aglutinação de sedimentos à bainha mucilaginosa produzida por cianobactérias. Uma vez formada a estrutura do estromatólito, ele se torna um sítio para a precipitação orgânica e/ou inorgânica de carbonato, resultando em sua litificação.

Mas o estudo das formas atuais tem uma limitação principal, o fato de que estromatólitos do Pré-Cambriano eram produzidos quase que exclusivamente por bactérias e cianobactérias, ao contrário do que ocorre atualmente onde há maior participação de organismos eucarióticos (Walter, 1994), conforme resumido na Figura 7. Pelo conteúdo microfossilífero presente em estromatólitos silicificados, Schopf (1992) afirma que desde o Paleoproterozóico até o Neoproterozóico os estromatólitos eram formados basicamente por organismos procariontes (bactérias e cianobactérias). 


\begin{tabular}{|r|l|}
\hline Tempo & \multicolumn{1}{|c|}{ Fanerozóico } \\
(Neoproterozóico?) & $\frac{\text { Bactérias + Cianobactérias + Microalgas + Metazoários }}{\pi}$ \\
Neoproterozóico & $\frac{\text { Bactérias + Cianobactérias + Microalgas }}{\pi}$ \\
Mesoproterozóico & $\underline{\text { Bactérias + Cianobactérias }}$ \\
Paleoproterozóico & Bactérias \\
Arqueano & $\underline{ }$ \\
\hline
\end{tabular}

Figura 7: Sucessão evolutiva-ecológica da composição das microbiotas construtoras de estromatólitos no decorrer do tempo geológico (Walter, 1994).

Desta forma a formação dos estromatólitos e, consequentemente, sua morfologia estão condicionadas a um balanço de fatores ambientais e biológicos. Em relação ao ambiente, esses fatores incluiriam principalmente, grau de agitação da água, correntes, profundidade, tipo de substrato (topografia, granulometria, composição, etc.), luminosidade, salinidade, temperatura, exposição sub-aérea, entre outros, enquanto os fatores biológicos incluiriam taxa de crescimento, composição taxonômica, hábito (filamentoso vs. cocóide colonial), produção de muscilagem, decomposição e destruição por outros organismos, etc. Na maioria dos casos, o ambiente determina a forma macroscópica do estromatólito (ou seja os morfotipos básicos; ver Figura 16, itens B e C) e a microbiota a meso- e microestrutura (ver Figura 16, itens $\mathrm{N}$ a S) (Walter, 1977). Como fica evidente nas figuras 8 e 16 (itens I e K), até alguns aspectos da macroestrutura podem ser influenciados pelos fatores biológicos. Assim, na parataxonomia binomial utilizada para diferenciar estromatólitos morfologicamente distintos, os grupos (táxon equivalente ao gênero) são definidos pela macroestrutura (morfologia colunar, ramificação) determinada por fatores ambientais e as formas (táxon equivalente à espécie) pelas feições meso- e microestruturais controladas em grande parte pelos fatores biológicos (Krylov, 1976; Trompette, 1982). 


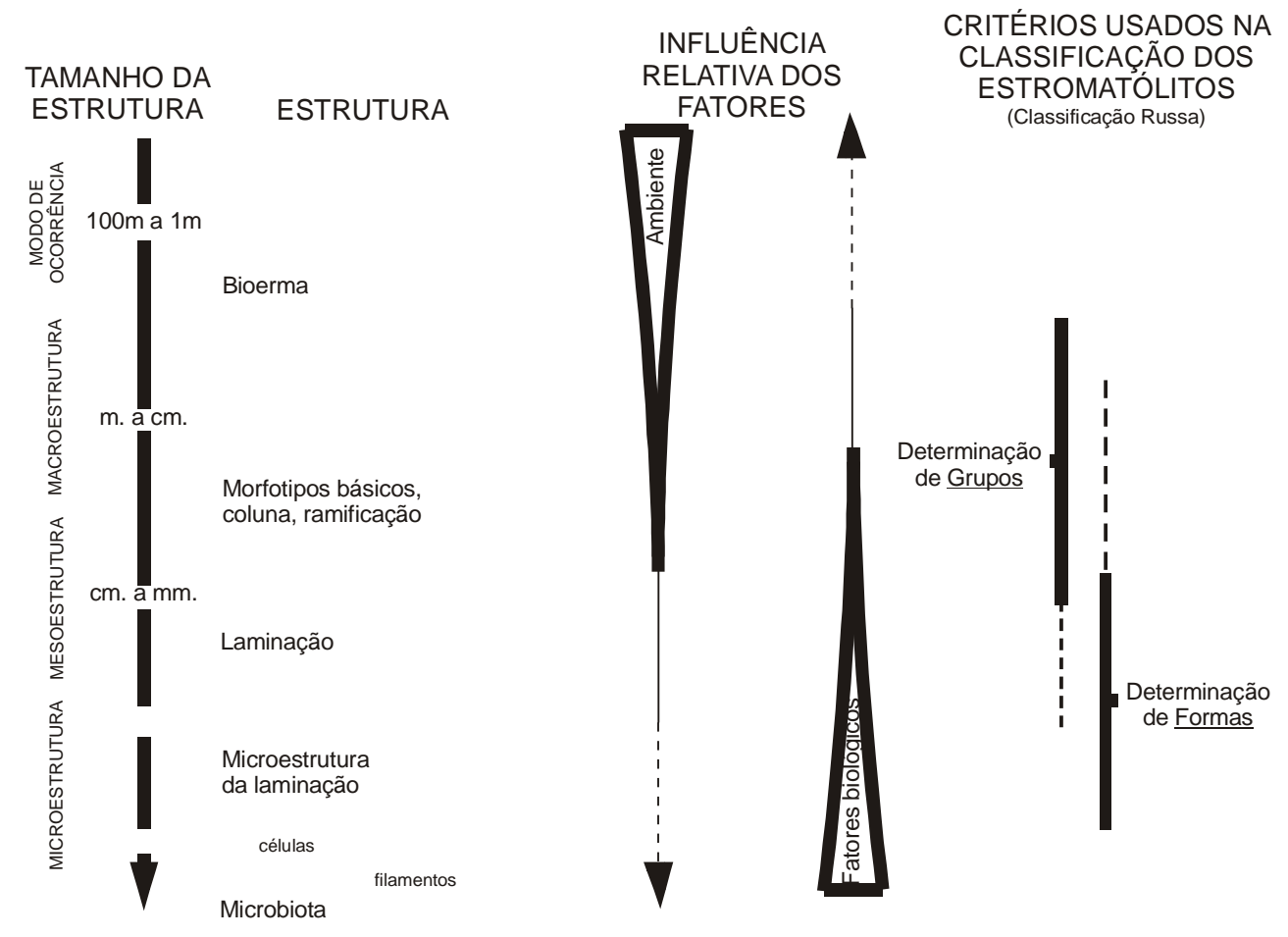

Figura 8: Influência relativa de fatores biológicos e ambientais na formação e morfologia de estromatólitos (Trompette, 1982).

A partir da percepção da influência destes dois fatores na formação dos estromatólitos, partiu-se para determinações paleoambientais. Um dos estudos mais importantes foi o de Hoffman (1976), realizado em Shark Bay (Austrália), no qual ficou demostrado que:

- Estromatólitos estratiformes ocorrem onde a abrasão provocada pela movimentação da água (ondas, maré) é fraca;

- Formas colunares discretas ocorrem onde a abrasão provocada pela movimentação da água (ondas, maré) é forte;

- O relevo das colunas é proporcional a intensidade da ação das ondas;

- A forma alongada de estromatólitos simples é paralela a direção das ondas e marés, geralmente perpendicular a linha de costa.

No mesmo ano, Donaldson (1976) interpretou o grau de turbulência e a profundidade do sítio de formação de diversas formas de estromatólitos do Grupo Dismal Lakes (Mesoproterozóico), do Canadá, com base nas estruturas sedimentares associadas, como resumido na Figura 9. 


\begin{tabular}{|c|c|c|c|c|c|c|c|c|}
\hline \multirow{2}{*}{$\begin{array}{l}\text { Morfologia dos } \\
\text { estromatólitos }\end{array}$} & \multicolumn{6}{|c|}{ Estruturas sedimentares } & Turbulência & \multirow{2}{*}{$\begin{array}{l}\text { inframaré } \\
\text { intermaré } \\
\text { supramaré }\end{array}$} \\
\hline & $\Lambda=$ & 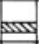 & $\odot$ & .1 & $\lambda$ & $m$ & baixa & \\
\hline$\approx \approx \approx \approx x$ & & & & $v$ & $v$ & $v$ & ----- & - \\
\hline 合园园 & $v$ & $v$ & $V$ & & $V$ & $v$ & --- & -- \\
\hline (1) ณ & $v$ & $V$ & $V$ & $v$ & $r$ & $v$ & - & -- \\
\hline 呢 & $v$ & $v$ & & v & & & - & --- \\
\hline 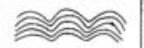 & $v$ & $v$ & & $v$ & & v & $--\square$ & --- \\
\hline बळब & $v$ & $r$ & $v$ & & & & ---- & $--\square$ \\
\hline 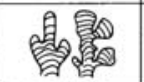 & $v$ & $V$ & & & & & & $---\cdots$ \\
\hline Ww & & & & & & & - & - \\
\hline
\end{tabular}

Marcas onduladas

IIII Estratificação cruzada

$\odot$ Oólitos

- 1 Moldes de halita e gipsita

ᄉ Gretas de dessecação

Ire Clastos intraformacionais

Figura 9: Interpretação paleoambiental a partir de tipos distintos de estromatólitos e estruturas sedimentares associadas no Grupo Dismal Lake, Canadá (Mesoproterozóico) (Donaldson, 1976).

Grotzinger (1989) demonstra a variação das formas em ambiente de rampa, característico do Proterozóico, tal como ilustrado na Figura 10, onde os membros típicos de águas profundas são os estromatólitos cônicos (Donaldson \& Taylor, 1972) e os de águas rasas as esteiras microbianas.

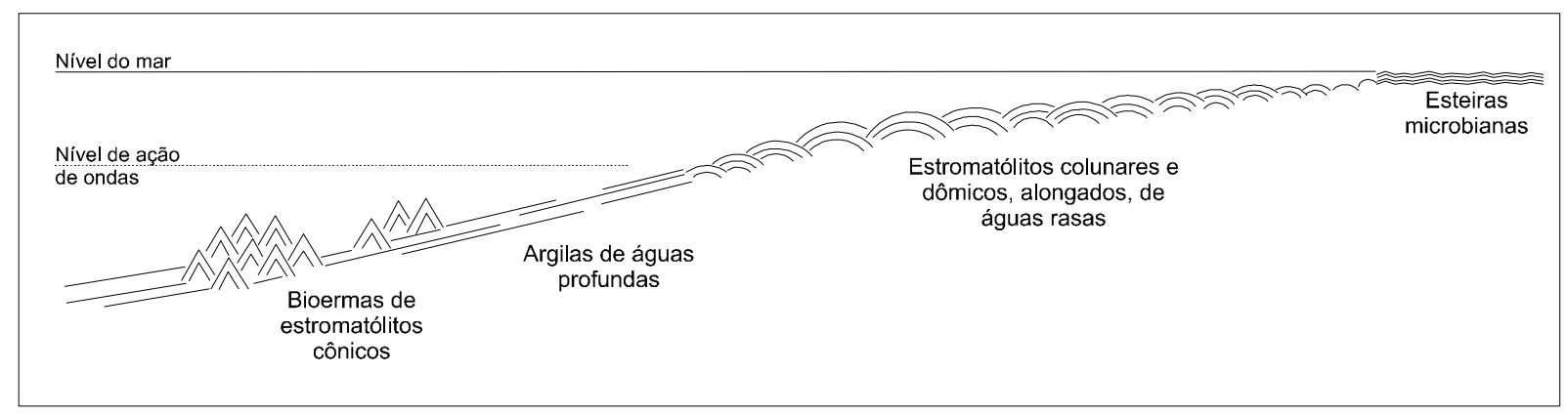

Figura 10: Variação das formas de estromatólitos em ambiente de rampa, segundo Grotzinger (1989).

Além de sua aplicação paleoambiental, os estromatólitos também foram utilizados na "bioestratigrafia" do Proterozóico (Semikhatov, 1976). Verificou-se, inicialmente na exUnião Soviética, que certas associações de formas de estromatólitos costumavam na mesma ordem em diversas províncias geotectônicas meso- e neoproterozóicas daquele país. Uma vez conhecidos os limites radiométricos das sucessões em que ocorriam, o reconhecimento dessas associações em outras regiões permitia uma certa correlação cronológica ocorrerem blocos relativamente grandes de tempo ( da ordem de 150 a 350 milhões de anos). Este esquema foi testado na África (Bertrand-Sarfati, 1972) e Austrália 
(Preiss, 1973; Walter, 1972) com certo êxito na década de 70. Desde então, porém, tem perdido credibilidade em parte devido à inflação de novos táxons e a dificuldade cada vez maior de diferenciar entre eles, mas principalmente por causa da percepção da forte influência ambiental na morfologia e, consequentemente, na determinação dos grupos de estromatólitos. Com efeito, hoje em dia pouquíssimos grupos e formas permanecem como indicadores temporais (vide p. ex. Preiss, 1976b).

Os estromatólitos ocorrem desde o Arqueano (Walter, 1994) mas foi no Proterozóico que eles apresentaram sua maior abundância e diversidade (Walter et al., 1992) (Figura 11). As formas mais antigas são coniformes e pseudo-colunares e foram descobertas recentemente no Grupo Warrawoona (Austrália), com 3,45 Ga (Hofmann et al., 1999). No final do Proterozóico houve uma queda em sua abundância e diversidade (Walter et al., 1992) (Figura 11). Este declínio foi considerado por Awramik (1971) como reflexo do aparecimento dos metazoários. Contudo, Walter et al. (1992) relacionam este fenômeno à conjunção de diversos fatores, como o aparecimento dos metazoários, o aumento das algas eucarióticas em relação as cianobactérias e fatores ambientais, como mudanças climáticas, por exemplo. Walter (1994) reconhece padrões no registro dos estromatólitos desde o Arqueano até hoje (Figura 12) que podem refletir mudanças na complexidade das relações ecológicas dos microorganismos formadores de estromatólitos (Figura 7). 


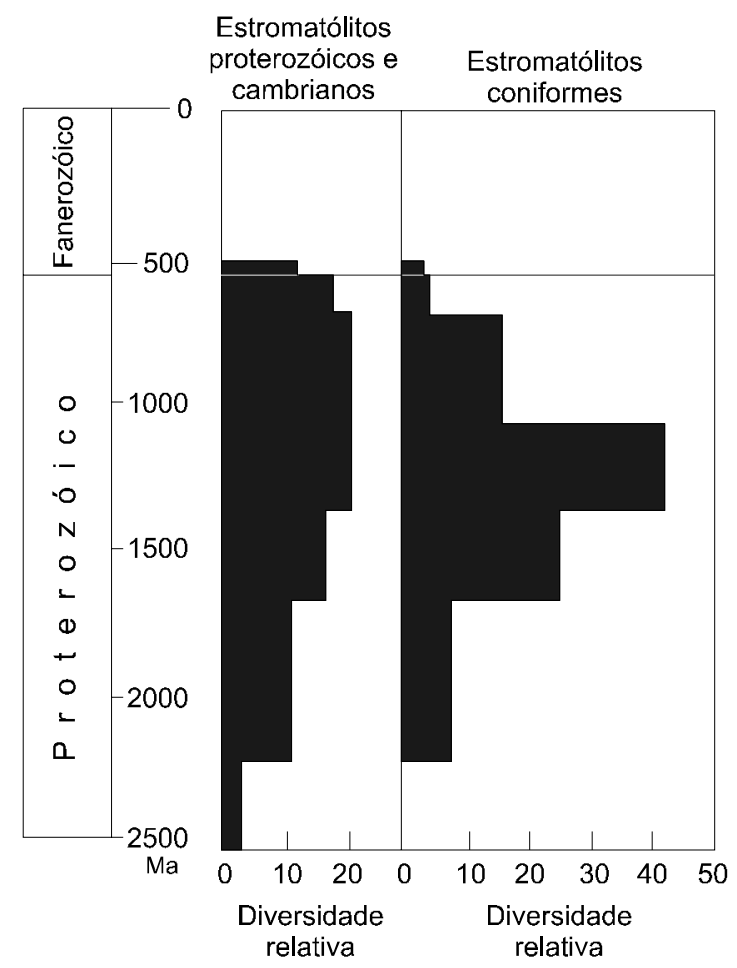

Figura 11: Diversidade relativa (número de formas por intervalo de tempo) de estromatólitos no Fanerozóico e no Pré-Cambriano (Walter et al., 1992). A base de dados compreende mais de 800 formas encontradas em 200 bacias.

$\begin{array}{ll}\begin{array}{l}\text { Ordoviciano inferior } \\ \text { Cambriano inferior }\end{array} & \begin{array}{l}\text { Os estromatólitos tornam-se raros. } \\ \text { Trombólitos tornam-se abundantes. }\end{array} \\ \begin{array}{l}\text { Neoproterozóico superior } \\ (700-600 \mathrm{Ma})\end{array} & \begin{array}{l}\text { Declínio na abundância ediversidade de todos os } \\ \text { estromatólitos. }\end{array} \\ \begin{array}{l}\text { Mesoproterozóico } \\ \text { Paleoproterozóico }\end{array} & \begin{array}{l}\text { Abundância de estromatólitos cônicos e de formas de } \\ \text { mini-estromatólitos, ambos com declínio posterior. }\end{array} \\ \begin{array}{l}\text { Arqueano superior } \\ (2,8-2,7 \mathrm{Ga})\end{array} & \begin{array}{l}\text { Estromatólitos mais abundantes e diversificados. } \\ \text { Arqueano inferior a médio }\end{array} \\ & \begin{array}{l}\text { Estromatólitos raros e pouco diversificados, não ocorrem } \\ \text { formas colunares com ramificações complexas. }\end{array}\end{array}$

Figura 12: Padrões reconhecidos na distribuição dos estromatólitos ao longo do tempo geológico (baseado em Walter, 1994). 


\subsection{Registros brasileiros}

Estromatólitos são conhecidos em diversas unidades carbonáticas brasileiras, principalmente de idade proterozóica, mas ainda são pouco estudados. Os estromatólitos mais antigos ocorrem no Supergrupo Minas, com idade entre 2,1-2,4 Ga (Dardenne \& Campos Neto, 1975; Souza \& Müller, 1984).

No final do Mesoproterozóico e início do Neoproterozóico formaram-se as sequências carbonáticas adjacentes ao Cráton do São Francisco, tal como o Grupo Paranoá, portador de rochas carbonáticas estromatolíticas nas seguintes regiões:

- Vazante (MG) (Moeri, 1972; Cloud \& Dardenne, 1973; Cloud e Moeri, 1973, Melo-Filho, 1996);

- Lagamar (MG) (Dardenne e Campos Neto, 1976; Nogueira e Dardenne, 1992);

- Cabeceiras (GO) (Fairchild et al., 1996).

Com uma idade próxima destacam-se também as ocorrências nas seqüências metassedimentares do sudeste brasileiro, dentro da Faixa Ribeira: Grupo Itaiacoca (Fairchild, 1977) e Formação Capiru (Fairchild, 1982) e Grupo São Roque (Bergmann \& Fairchild, 1985). Tanto no Grupo Paranoá quanto no Grupo Itaiacoca ocorrem formas atribuídas ao grupo Conophyton.

No Neoproterozóico as principais ocorrências, incluindo uma grande variedade de formas, estão nas coberturas neoproterozóicas do Cráton do São Francisco como os grupos Bambuí e Una (Marchese, 1974; Cassedanne \& Cassedanne, 1978; Srivastava, 1982; entre outros). Também ocorrem na Faixa Paraguai, no Grupo Corumbá e Formação Araras (Zaine, 1991; Zaine \& Fairchild, 1992; Boggiani et al. 1996; Boggiani, 1997; Sallun Filho et al., 1997).

Em diversas das unidades citadas acima ocorrem microfósseis associados a estromatólitos silicificados como descritos no Grupo Bambuí e no Grupo Paranoá, recentemente resumidos por Fairchild et al. (1996).

Estromatólitos fanerozóicos são conhecidos no Permiano da Bacia do Paraná, especificamente na Formação Irati (Fairchild et al., 1985), na Formação Corumbataí (Suguio \& Melo e Souza, 1985) e na Formação Estrada Nova (Rohn \& Fairchild, 1985). Do cretáceo é conhecido ocorrências na Bacia de Campos e Potiguar (Carvalho, 1988; Monteiro \& Faria, 1988). Estromatólitos recentes a sub-recentes também são conhecidos na Lagoa Salgada, RJ (Lemos \& Silva, 1994). 


\section{MATERIAIS E MÉTODOS}

\subsection{Análise dos estromatólitos}

Para a análise dos estromatólitos procurou-se sistematizar o trabalho e fazer descrições mais detalhadas possíveis. Adotou-se um guia para descrever os estromatólitos, adaptado de diversos autores (como Hofmann, 1969; Walter, 1972; Grey, 1989; Grey, 1989) por T.R. Fairchild (inédito) (Figura 16) que enfatiza observações objetivas em quatro escalas:

1) Modo de ocorrência: estromatólitos como corpo geológico e sua geometria (lentes, camadas, indivíduos dispersos, etc.);

2) Macroestrutura: geometria dos estromatólitos individuais;

3) Mesoestrutura: principalmente as feições mais evidentes da laminação;

4) Microestrutura: arranjo interno das lâminas.

Destas quatro escalas de observação pode-se dizer que a promeira é observável exclusivamente no campo, a segunda e terceira em campo ou em laboratório, e a quarta essencialmente em laboratório. Deste modo, primeiramente os dados de campo foram obtidos e posteriormente reunidos e complementados por trabalhos de laboratório para caracterizar a morfologia dos estromatólitos.

A ênfase foi dada a formas colunares, na abordagem da metodologia, por essas serem as únicas formas encontradas na área, não sendo observadas nem formas estratiformes (esteiras) nem formas soltas (oncólitos).

\subsubsection{Descrição de campo}

Os trabalhos de campo visaram, sobremaneira, a descrição de localidades fossilíferas (já conhecidas e novos achados), e a caracterização estratigráfico-estrutural das ocorrências principais, bem como de pontos com outros tipos litológicos que ocorrem dentro do Grupo Itaiacoca.

Foram realizados cinco etapas de campo, nos períodos de 05 a 07/09/97, 11 a 14/02/98, 30/04 a 03/05/98, 05 a 08/09/98, 15 a 18/10/98 e 17 e 18/04/99, totalizando 21 dias. A primeira etapa teve essencialmente caráter de reconhecimento das principais ocorrências de estromatólitos. Nas outras etapas procurou-se reconhecer ocorrências menores, descobrir novas ocorrências estromatolíticas e caracterizar outras litologias importantes para o estudo. Os pontos visitados, bem como os caminhamentos, foram 
lançados imediatamente em mapa topográfico (1:50.000), usando suas coordenadas UTM ainda em campo, de aparelho GPS ${ }^{1}$. Cada afloramento foi documentado com anotações, desenhos, fotografias e também medidas estruturais. Procurou-se coletar amostras em cada ponto para ter um conjunto dos tipos litológicos que ocorrem na área. No total foram descritos 55 pontos, sendo que nove continham estromatólitos.

Para a análise dos estromatólitos em campo foi adotada, em parte, o guia de observação proposto por Preiss (1976a), que visa a descrição de:

a) Estruturas estromatolíticas em grande escala - natureza das camadas:

- espessura das camadas;

- ciclicidade de estromatólitos e sedimentos associados;

- extensão lateral;

- forma da camada e relações com as rochas que a englobam;

- litologias.

b) Estruturas estromatolíticas em escala intermediária:

- natureza dos estromatólitos nas camadas estromatolíticas;

- relações verticais e laterais;

- ramificações;

- forma das colunas em seções longitudinais e transversais;

- orientação relativa (formas colunares);

- natureza das margens (formas colunares);

- forma da laminação;

- variações laterais e/ou verticais nas características acima, quando traçadas através do bioerma ou bióstromo, especialmente nas margens do bioerma;

- natureza dos sedimentos nos espaços entre as colunas.

Este roteiro pode ser respondido por completo quando a qualidade de preservação e/ou dos afloramentos permita.

A macro- e mesoestrutura dos estromatólitos foram descritas e suas dimensões e orientações medidas. Também mediram-se estruturas como acamamento, foliação e clivagem. Foram coletadas amostras, principalmente nas ocorrências novas, de acordo com procedimentos costumeiros. Para Preiss (1976a), a coleta deve ser seletiva, e as

1 Modelo 12 - Garmin. 
amostras devem mostrar, pelo menos em uma superfície, um corte limpo de várias colunas e, ser representativas de todo afloramento (amostras do centro, das margens, da base e do topo dos bioermas) (Figura $13 \mathrm{~A}$ ). Amostras menores devem ser selecionadas para ilustrar variações verticais de uma morfologia para outra ou mudanças no estilo da ramificação (Figura 13 A e B). No caso de estromatólitos grandes demais para ser manejados ou coletados, deve-se fazer observações de campo cuidadosas, e preferencialmente em faces de diferentes orientações. Amostras podem então ser coletadas para mostrar porções das colunas e os detalhes da laminação.

A

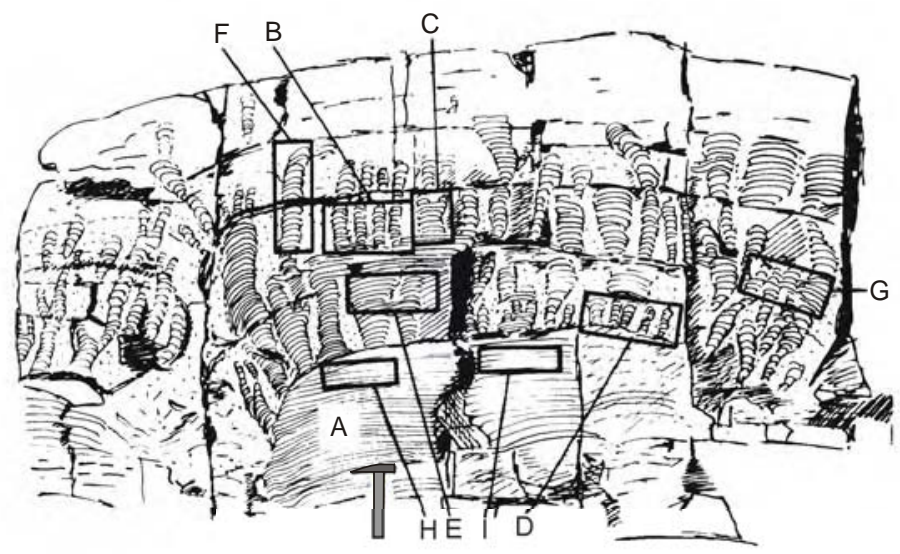

B

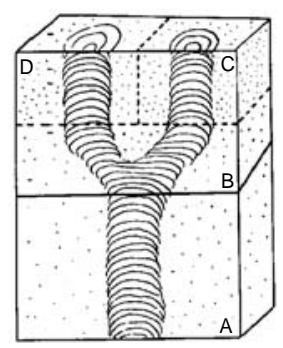

Figura 13: A - Exemplo de um bioerma com grande variedade morfológica, ilustrando a dificuldade de descrever estromatólitos. Segundo a parataxonomia desenvolvida pelos soviéticos, cada região marcada por uma letra diferente receberia uma designação binomial (grupo, forma) diferente. Ter-se-ia de coletar amostras para obter uma boa representatividade do conjunto

(Krylov, 1976). B - Desenho mostrando a dificuldade da identificação de estromatólitos dependendo do tamanho da amostra (Krylov, 1976). Se a amostra fosse apenas A, C ou D o estromatólito não seria classificado como ramificado.

\subsubsection{Trabalhos de laboratório}

Além dos trabalhos de campo foram desenvolvidas algumas análises em laboratório, visando uma caracterização mais detalhada dos estromatólitos. Para tal foram utilizadas cerca de 103 amostras de estromatólitos da área estudada, mais 10 amostras 
para comparação. Este material incluiu alguns tipos e material previamente ilustrado, e amostras de outras localidades.

Seguiu-se o seguinte procedimento:

1) Limpeza e cadastramento próprio das amostras através de um código de acordo com a localidade.

2) Fotografia das amostras antes de serem cortadas.

3) Cortes com uma serra com disco diamantado, do Laboratório de Tratamento de Amostras (LTA), do Departamento de Mineralogia e Geotectônica do IG/USP. Das 103 amostras analisadas obtiveram-se cerca de 270 cortes, gerando aproximadamente 540 faces e 380 peças individuais. Quando possível, s cortes foram feitos em série para obter fatias para visualizar melhor as estruturas em três dimensões (Figura 14).

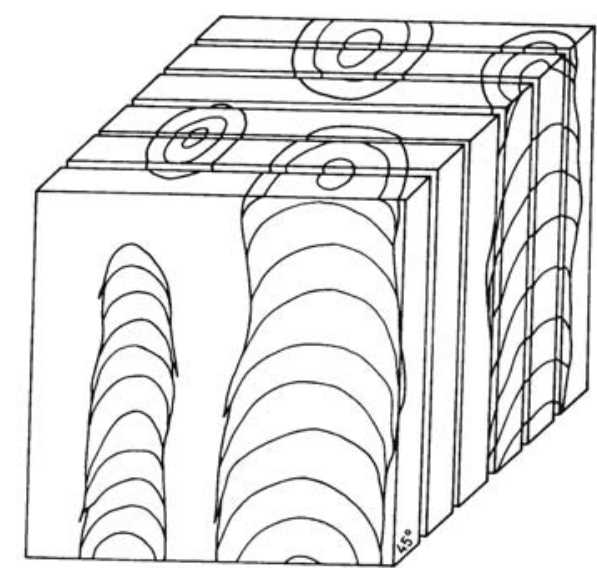

Figura 14: Amostra estromatolítica cortada em fatias (Walter, 1972).

4) Polimento das faces cortadas com lixadeira/politriz ${ }^{2}$, partindo-se de uma lixa mais grossa para uma mais fina, até desaparecerem as marcas da serra e atingir um brilho suave.

5) Envernizamento das faces cortadas com spray de verniz incolor para evitar dispersão da luz da superfície áspera e assegurar uma boa visualização das estruturas.

\footnotetext{
${ }^{2}$ Modelo 9207 SPB - Makita.
} 
6) Fotografia ${ }^{3}$ de cada face cortada, em uma estativa com duas lâmpadas photoflood azuis de 250 watts e filme Kodak Gold (ASA-100). Foram tomadas cerca de 340 fotografias de amostras. As lâminas delgadas foram colocadas sobre uma mesa de luz e fotografadas com lente macro com bons resultados.

7) Desenhos detalhados dos estromatólitos a partir de faces cortadas e/ou de fotos. Foram feitos cerca de 150 desenhos de amostras de estromatólitos. Os traços de estruturas nos estromatólitos foram copiados diretamente das amostras em folhas de acetato transparente com caneta de retroprojetor de ponta fina, tomando cuidado para desenhar apenas os contornos realmente discerníveis e representativos e evitando traços interpretativos ou inferidos. Estes desenhos foram posteriormente fotocopiados e os mais significativos digitalizados. Parte da digitalização foi realizada com mesa digitalizadora utilizando o software AutoCAD r.13 $3^{4}$ e outra parte foi digitalizada a partir de um scanner, e ambas vetorizadas pelo software Corel OCR-TRACE $7^{5}$.

8) Análise morfométrica, baseada na medição de feições morfológicas tais como altura, largura, espessura de laminação, etc. (Figura 15).

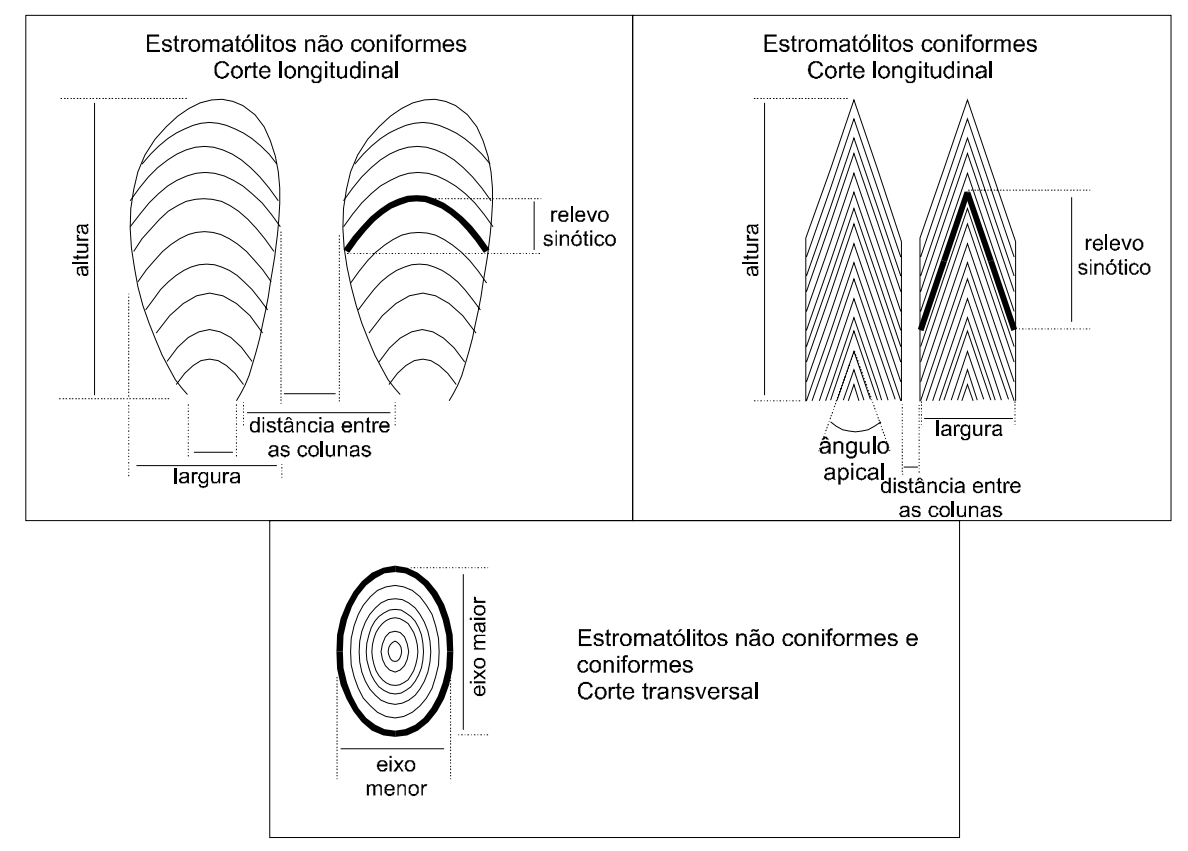

Figura 15: Alguns dos caracteres medidos em amostras de estromatólitos colunares coniformes e não coniformes.

\footnotetext{
3 máquina da marca Pentax, modelo MZ-50, lente 35-80 mm e lente macro $100 \mathrm{~mm}$.

4 Autodesk Inc..

5 Corel Corporation.
} 
9) Para os estromatólitos coniformes, tanto da área estudada quanto de outras localidades, um procedimento especial foi adotado. Foram desenhados os traços unindo os pontos de maior espessura da laminação na zona axial. Foram analisadas lâminas petrográficas visando a caracterização da microestrutura, principalmente da laminação e da zona axial. A maioria destas lâminas petrográficas foi confeccionada em tamanho grande (aproximadamente $7 \times 5 \mathrm{~cm}$ ) em corte longitudinal contendo o eixo ou zona axial e com espessura em torno de $50 \mu \mathrm{m}$. Algumas lâminas antigas confeccionadas por T .R. Fairchild chegam a tamanhos até maiores. No total foram analisadas 11 lâminas. Nestas lâminas foi medida a espessura das lâminas claras e escuras, externas à zona axial, em microscópio óptico ${ }^{6}$ utilizando um micrômetro ocular. Posteriormente, elaboraram-se gráficos de freqüência relativa dos valores obtidos, subdividido em classes de 0,04 mm. A partir de fotografias de lâminas petrográficas foram elaborados também desenhos das lâminas escuras utilizando uma área padrão de $1 \mathrm{~cm}^{2}$.

10) As amostras mais significativas foram incorporadas às coleções do Laboratório de Paleontologia Sistemática do IG/USP, e os seus respectivos números encontram-se listados no Anexo 5.

Na descrições dos estromatólitos seguiu-se o esquema sugerido por utilizado por Walter (1972), que é: arranjo das colunas, forma das colunas, forma das lâminas, textura e microestrutura. As feições observadas foram denominadas de acordo com o guia de Fairchild (inédito) (Figura 16), citando adicionalmente o códigos estabelecido para os caracteres, por exemplo:

Bioerma tabular $=$ A.1

Contorno em planta equidimensional arredondado = F.1

A terminologia adotada se baseia em critérios morfológicos os mais objetivos possíveis, dividindo os diferentes morfotipos em "formas". Não se utilizaram denominações binomiais do tipo "grupo e forma", equivalente a "gênero e espécie", como utilizadas em muitos trabalhos soviéticos (p. ex., Semikhatov, 1976), pois atualmente sabe-se que este tipo de classificação, se não feita com muito cuidado em material muito bem preservado, é pouco funcional. Preferiu-se não aplicá-la pois o material analisado é muito deformado, ou seja, a preservação não é boa e poderia propiciar algumas

\footnotetext{
${ }^{6}$ Modelo BXP 40 - Olympus. Laboratório de Microscopia (IG-USP).
} 
classificações incorretas. Além disso atualmente existe uma grande quantidade de grupos e formas descritos na literatura o que poderia suscitar certa confusão. Uma exceção é feita no caso dos estromatólitos cônicos (Conophyton, grupo bastante comum e diversificado do Meso e Neoproterozóico) cuja geometria bastante regular permite sua identificação relativamente fácil. A classificação operacional adotada, baseada principalmente na distinção entre morfotipos distintos e na sua enumeração, foi adequada para este estudo.

\subsubsection{Outras análises}

Para determinar a porcentagem de resíduo insolúvel nos estromatólitos em três localidades dissolveram-se nove amostras, utilizando $\mathrm{HCl}(20 \%)$ aquecido. Realizou-se, também, análise química semi-quantitativa por EDS (espectrometria de energia dispersiva), acoplado ao microscópio eletrônico de varredura ${ }^{7}$ do Laboratório de Microscopia Eletrônica, Departamento de Geologia Sedimentar e Ambiental (IG-USP), em fragmentos das mesmas amostras dissolvidas recobertas por finas películas de ouro.

Para realçar a estrutura estromatolítica em superfícies naturais frescas e faces cortadas e polidas de alguns estromatólitos em calcários calcíticos cinza escuros, que quase sempre revelam menos detalhes do que as intemperisadas naturalmente, realizaram-se ataques rápidos (1 a 2 minutos) de $\mathrm{HCl}$ à frio (10-20\%). Isto ressaltou a laminação estromatolítica e o contraste entre os estromatólitos (mais escuros) e os sedimentos clásticos circundantes (mais claros), tão bem quanto o intemperismo natural, se não melhor.

${ }^{7}$ Modelo Leo 440i. 


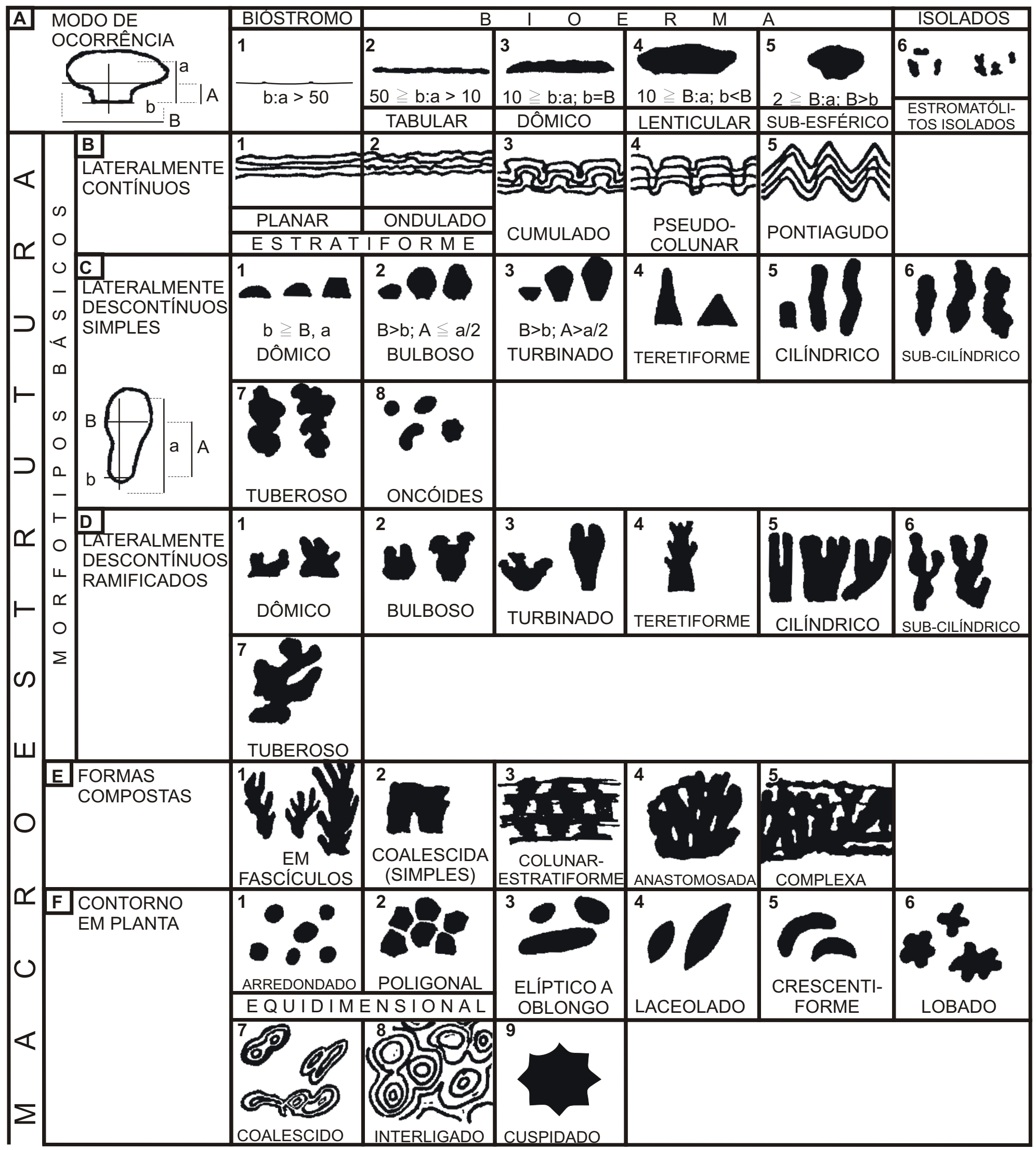




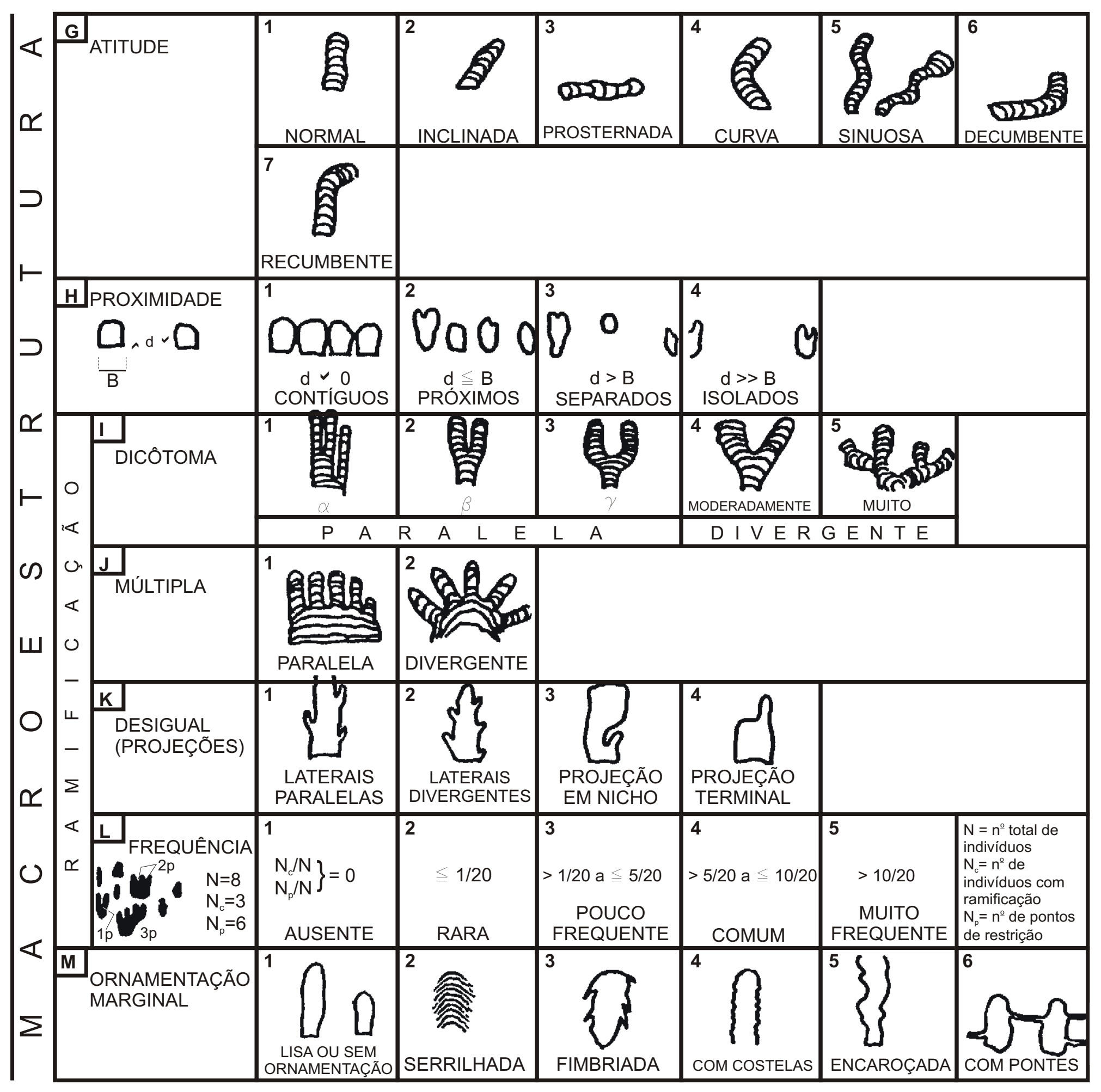




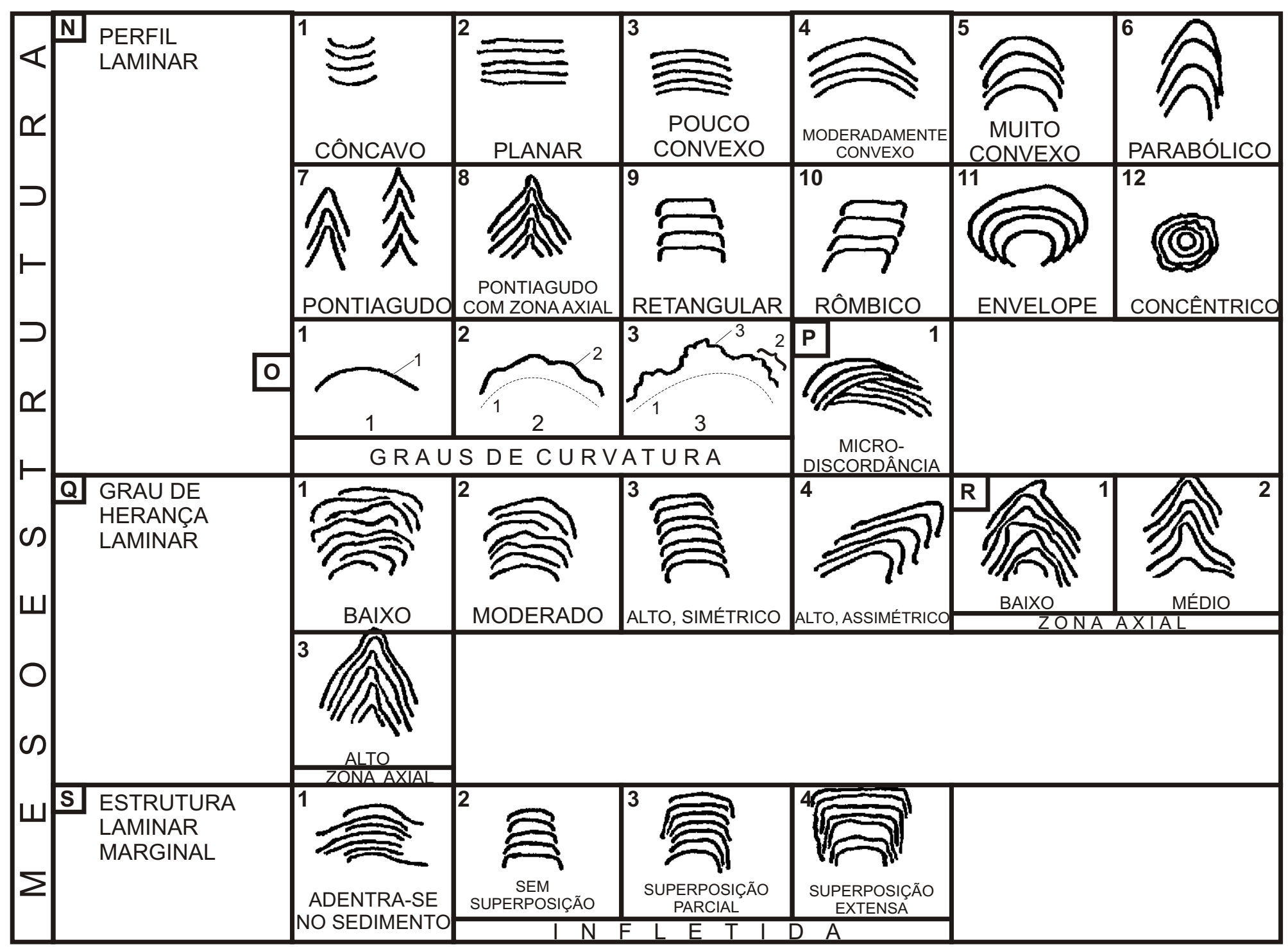

Figura 16: Guia para classificação de estromatólitos (Fairchild, inédito; adaptado de Grey, 1989). 


\subsubsection{Critérios operacionais para identificar estromatólitos}

O primeiro passo no estudo de estromatólitos é mostrar sua biogenicidade. O próprio termo estromatólito implica em uma origem biogênica.

A identificação de estromatólitos se baseia na presença de uma laminação fina, ondulada, geralmente convexa, formando construções discretas ou na forma de esteiras lateralmente extensas. Walter (1994) frisa os seguintes critérios para mostrar a biogenicidade destas estruturas:

1- relação sinsedimentar com o acamamento;

2- macromorfologia coerente com formas presentes em estromatólitos, p. ex. em colunas;

3- meso- e micromorfologias coerentes com origem estromatolítica, p. ex. laminação convexa para cima;

4- composição química coerente com uma origem estromatolítica, p. ex. carbonática.

Mesmo com estes critérios a biogenicidade pode ser atribuída erroneamente a outras estruturas inorgânicas que possuem características semelhantes. Como por exemplo espeleotemas, que englobam uma grande variedade de depósitos de calcita secundária em áreas cársticas (Thrailkill, 1976). Apresentam composição carbonática e formas que se assemelham aos estromatólitos colunares - as estalagmites (colunas com lâminas convexas para cima) - e aos oncóides - as "pérolas" (formas soltas com laminação concêntrica). No presente estudo, os espeleotemas foram diferenciados dos estromatólitos principalmente por sua laminação mais regular e por não formar grandes construções, mas ocorrerem de forma mais restrita. Mesmo assim em alguns casos esta distinção ficou difícil. As estruturas na qual persistiu alguma dúvida não foram utilizadas, ou utilizadas com ressalva.

Estruturas produzidas pela deformação de rochas carbonáticas também podem ser confundidas com estromatólitos, como dobras isoclinais ou em bainha, por exemplo. Quando observam-se calcários maciços deformados e/ou dolomitizados, imagina-se uma existência pretérita de estromatólitos. Isto é baseado no aspecto "maciço versus laminado" dos calcários, onde os calcários estromatolíticos não apresentam estratificação evidente. 
A qualidade da preservação dos estromatólitos é um ponto fundamental para seu reconhecimento. Quanto melhor a preservação, mais fácil sua caracterização. Na área estudada a qualidade de preservação dos estromatólitos varia muito, devido à dolomitização e/ou à deformação, chegando em alguns locais a ser péssima. Walter (1972) define três classes de preservação baseadas na nitidez das margens dos estromatólitos colunares:

1) Bem preservado, com colunas distintas;

2) Margens das colunas ligeiramente alteradas ou indistintas;

3) Colunas muito indistintas ou alteradas.

Entretanto, estas classes não contemplam a qualidade de preservação da laminação estromatolítica. Como na área de estudo um estromatólito pode ter colunas indistintas mas laminação bem preservada ou vice-versa, adotou-se o seguinte esquema para caracterizar a qualidade de preservação dos estromatólitos:

Considerando as colunas:

Classe 1 - Bem preservado, com colunas distintas;

Classe 2 - Margens das colunas ligeiramente alteradas ou indistintas;

Classe 3 - Colunas muito indistintas ou alteradas;

Considerando a laminação:

Classe 1 - Bem preservado, com laminação distinta;

Classe 2 - Laminação ligeiramente alterada ou indistinta;

Classe 3 - Laminação muito indistinta ou alterada.

\subsection{Digitalização de mapas}

Utilizaram-se o software AutoCAD r.13 e mesa digitalizadora, para digitalizar os dados topográficos e geológicos da área estudada. Isto facilitou a locação dos pontos e a compilação e integração de novas informações da literatura e de campo garantir uma boa qualidade gráfica da parte cartográfica deste trabalho.

Para confecção do mapa de pontos foi digitalizado o mapa topográfico da área, na escala 1:50.000 (IBGE, 1975; Folha Ribeirão Branco, SG.22-X-B-II-1) (Figura 18). Os pontos visitados foram lançados através de suas coordenadas em UTM obtidas com GPS.

O mapa geológico da Faixa Itaiacoca no estado de São Paulo (Figura 2) foi primeiramente compilado em papel vegetal, a partir dos trabalhos de Takahashi et al. 
(1984), Bistrichi et al. (1985) e Theodorovicz et al. (1986), e posteriormente digitalizado. Já o mapa geológico da área de estudo, propriamente dita, foi compilado a partir do trabalho de Theodorovicz et al. (1986) e digitalizado (Figura 3). Após a digitalização estes dois mapas foram editados no software CoreIDRAW $7^{8}$.

\section{CARACTERIZAÇÃO DOS ESTROMATÓLITOS}

\subsection{Trabalhos prévios}

A primeira descrição de fósseis pré-cambrianos na América do Sul foi de Almeida (1944) que notou a presença de estruturas biogênicas em calcários da "Série" Açungui, denominando-as Collenia itapevensis. Neste trabalho, ele descreveu três ocorrências destes estromatólitos na região ao sul de Itapeva (SP), a primeira "a 3 quilômetros no rumo $35^{\circ} \mathrm{SW}$ da vila Campina dos Veados" (atual Nova Campina), a segunda nos "sítios Boa Vista e Lavrinhas" na rodovia Itapeva-Ribeirão Branco e a terceira "junto à confluência do córrego da Onça com o córrego Fundo...a cerca de 3 quilômetros a NNE do sítio Boa Vista". As duas primeiras ocorrências descritas por Almeida (1944) corresponderiam respectivamente, aos pontos 11 e 27 do presente trabalho (Figura 17, pontos 1 e 4; Figura 18). Este autor informou ainda que ocorriam mais de trinta pedreiras com estromatólitos, mas observou que em Nova Campina as estruturas eram melhor preservadas do que nas outras localidades, onde o dolomito estromatolítico encontrava-se recristalizado. O holótipo e os parátipos dos estromatólitos descritos por Almeida (1944), encontram-se nas coleções do DNPM, do Instituto Geológico de São Paulo (Secretaria do Meio Ambiente) e do Instituto de Geociências da Universidade de São Paulo. Algumas destas amostras foram colocadas a disposição para este estudo, estão ilustradas na Est. II (B a D) e listadas nos anexos 2 e 3.

Posteriormente, Almeida (1957) descreveu outras ocorrências de estromatólitos, distintos de Collenia itapevensis, na região de Abapã (Figura 17, pontos 13 e 14), Socavão (Figura 17, ponto 12) e Varzeão (Figura 17, ponto 11), no estado do Paraná, na mesma faixa de carbonatos que ocorre ao sul de Itapeva. Ainda neste mesmo trabalho, descreveu supostos estromatólitos muito deformados a SE de Abapã, na região de Erval, hoje atribuídos à Formação Água Clara. Além destas ocorrências no Paraná, Almeida (1957) ainda informa duas outras ocorrências de estromatólitos ao sul de Itapeva, não

\footnotetext{
${ }^{8}$ Corel Corporation.
} 
localizadas durante o presente estudo. Tanto em Itapeva quanto em Abapã, Almeida (1957) chamou a atenção para a eventual utilidade destas estruturas em correlações locais e como marcadores estratigráficos.

Na mesma época, mais ao sul, no estado do Paraná, Bigarella \& Salamuni (1958) descreveram estromatólitos na Formação Capiru, do Grupo Açungui. Mais tarde, Marini \& Bósio (1971) descreveram duas ocorrências de estromatólitos no Paraná, uma no Grupo Itaiacoca (na região de Abapã) (Figura 17, ponto 14) e outra na Formação Capiru, do Grupo Açungui (na região de Rio Branco do Sul) (Figura 17, ponto 18). Estes autores postularam que se confirmadas as diferenças morfológicas entre os estromatólitos das duas formações, eles poderiam servir como critério para distinção entre as duas unidades. Tentativamente, atribuíram as formas encontradas no Grupo Itaiacoca, ao "supergupo Conophytonida", da classificação de Raaben (1969) caracterizado por "colunas cilíndricas com seção oval ou circular e não ramificadas" que tem Conophyton como grupo principal.

O primeiro estudo mais detalhado desses estromatólitos foi feito por Fairchild (1977) que reestudou os estromatólitos na região ao sul de Itapeva, nas localidades descritas por Almeida em 1944, reconhecendo em Collenia itapevensis duas formas distintas. Uma destas foi relacionada ao Conophyton garganicum, conhecido de sucessões do Neoproterozóico inferior e Mesoproterozóico em outras partes do mundo, e bem distinto das formas de estromatólitos, ainda não classificadas, da Formação Capiru. Com base em estromatólitos Fairchild (1977) estabeleceu o ambiente deposicional de águas calmas, sub-litorâneas, para os carbonatos da Formação Itaiacoca e sugeriu uma idade aproximada (entre 0,85 e 1,7 Ga) através da semelhança entre o Conophyton da região de Itapeva (SP) e C. garganicum. Devido às diferenças constatadas na morfologia e modo de ocorrência dos estromatólitos nos grupos Itaiacoca e Açungui/Capiru, Fairchild (1977) aventou também a possibilidade das principais unidades estromatolíticas da Faixa Ribeira, terem histórias geológicas distintas.

Em estudo posterior, em torno do Anticlinal de Setuva, leste do estado do Paraná, Fairchild (1982) descreveu uma nova forma de estromatólito colunar em dolomitos da Formação Capiru do Grupo Açungui em duas localidades distantes 25 km entre si (Figura 17, pontos 16 e 18). Estes estromatólitos são formas colunares, muito pequenas, abundantes, paralelos a sub-paralelos e com raras ramificações. São muito distintos de qualquer outra forma descrita no Brasil, inclusive os da Formação Itaiacoca. A ocorrência destes estromatólitos em dois locais distantes levou Fairchild (1982) a propor seu uso para correlação física e até temporal (horizonte guia) dentro da Formação Capiru. 
Finalmente, Fairchild \& Theodorovicz (1989) relataram novas ocorrências de estromatólitos na folha Ribeirão Branco, destacando uma na Fazenda Santo Antônio (Figura 17, ponto 1), que possui formas que lembram Conophyton, estendendo a presença deste tipo de estromatólito até o limite NE do Grupo Itaiacoca, vários quilômetros a nordeste das localidades clássicas de Almeida (1944). 


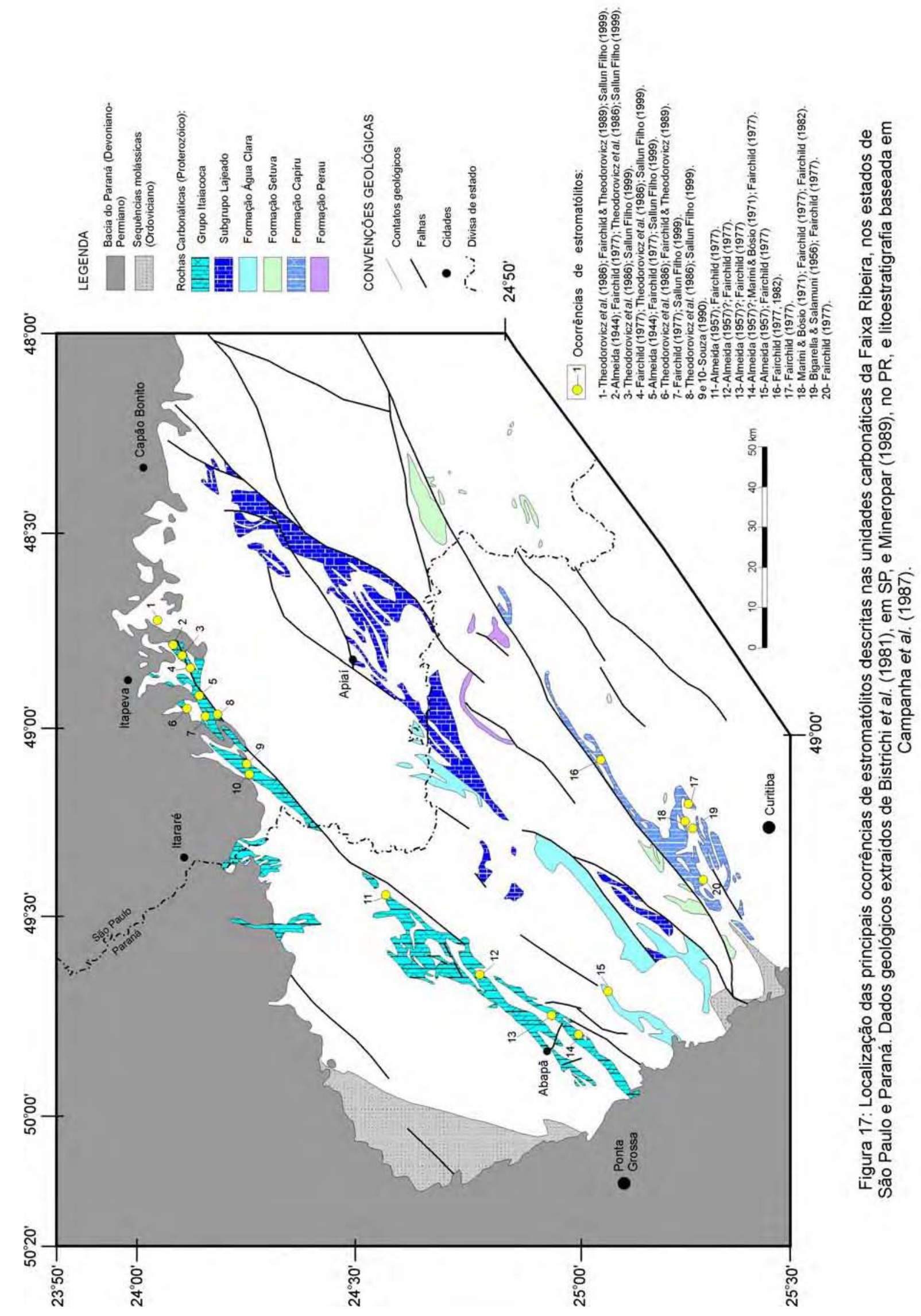




\section{ESTAMPA II}

A - "Collenia itapevensis", reprodução da Figura I, Estampa IV do trabalho original de F.F.M. de Almeida.

B - Amostra (IG-213) de "Collenia itapevensis" coletada por F.F.M. de Almeida da localidade de Nova Campina, depositada na Coleção do Instituto Geológico.

C - Parátipo de "Collenia itapevensis" coletado por F.F.M. de Almeida, depositado na Coleção do Laboratório de Paleontologia Sistemática, IG/USP (GP/3T-80).

D - Amostra de "Collenia itapevensis" coletada por F.F.M. de Almeida (Coleção DNPM, sem número). 

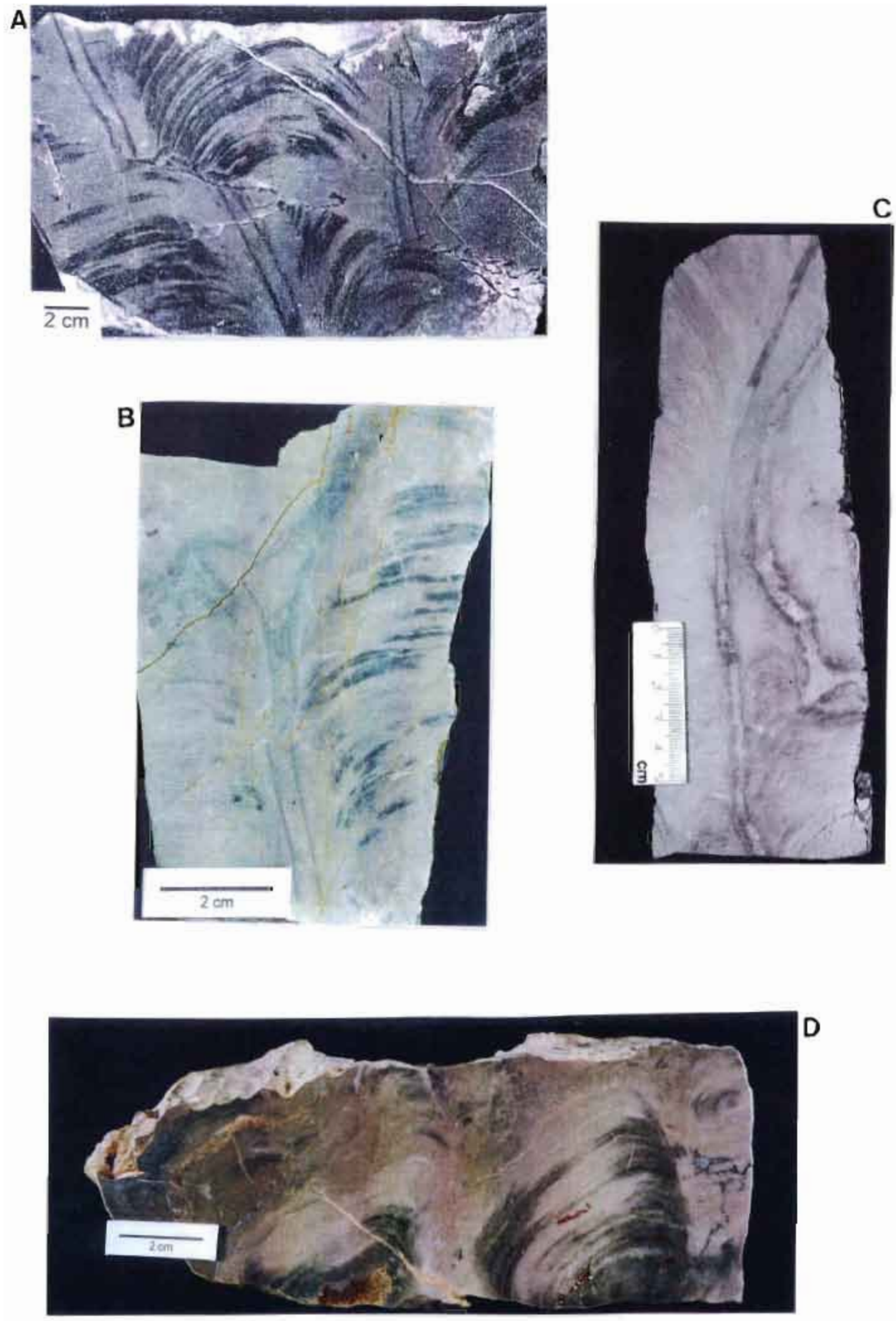


\subsection{Descrição das ocorrências}

Para o estudo dos estromatólitos foram analisadas as nove localidades listadas abaixo, com as siglas adotadas aqui (Tabela 4) e os números dos pontos, que estão locados no Mapa de Pontos (Figura 18). Dessas nove localidades cinco são ocorrências já conhecidas (LAV, IND, FSA, NCM e CHB), três já eram conhecidas, mas não estudadas (TGU, ITN e IB1) e uma é nova (IB2).

\begin{tabular}{|c|c|c|c|}
\hline Localidade & Sigla & № do ponto & Situação \\
\hline Pedreira Lavrinhas & LAV & $\begin{array}{l}02 \\
27\end{array}$ & $\star$ \\
\hline Pedreira Indumine & IND & 09 & $\star$ \\
\hline Frente em Nova Campina & NCM & 11 & 录 \\
\hline Pedreira Itanguá & ITN & 16 & 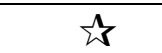 \\
\hline Pedreira na fazenda Santo Antônio & FSA & 17 & $\vec{s}$ \\
\hline Pedreira no bairro Taquari-Guaçu & TGU & 19 & tr \\
\hline Pedreira na estrada Brancal-Indumine (1) & IB1 & 31 & ts \\
\hline Frente na estrada Brancal-Indumine (2) & IB2 & 35 & $\vec{s}$ \\
\hline Pedreira Chiquinho de Barros & CHB & $44 a, b$ & tr \\
\hline
\end{tabular}

Ativa; Abandonada

Tabela 4: Situação dos afloramentos descritos, com as siglas adotadas e seus respectivos números de ponto.

Todas estas ocorrências estão alinhadas SW-NE (Figura 18), essencialmente dentro de uma mesma faixa de metacalcários que ocorre na porção central da área (Figura 3). 


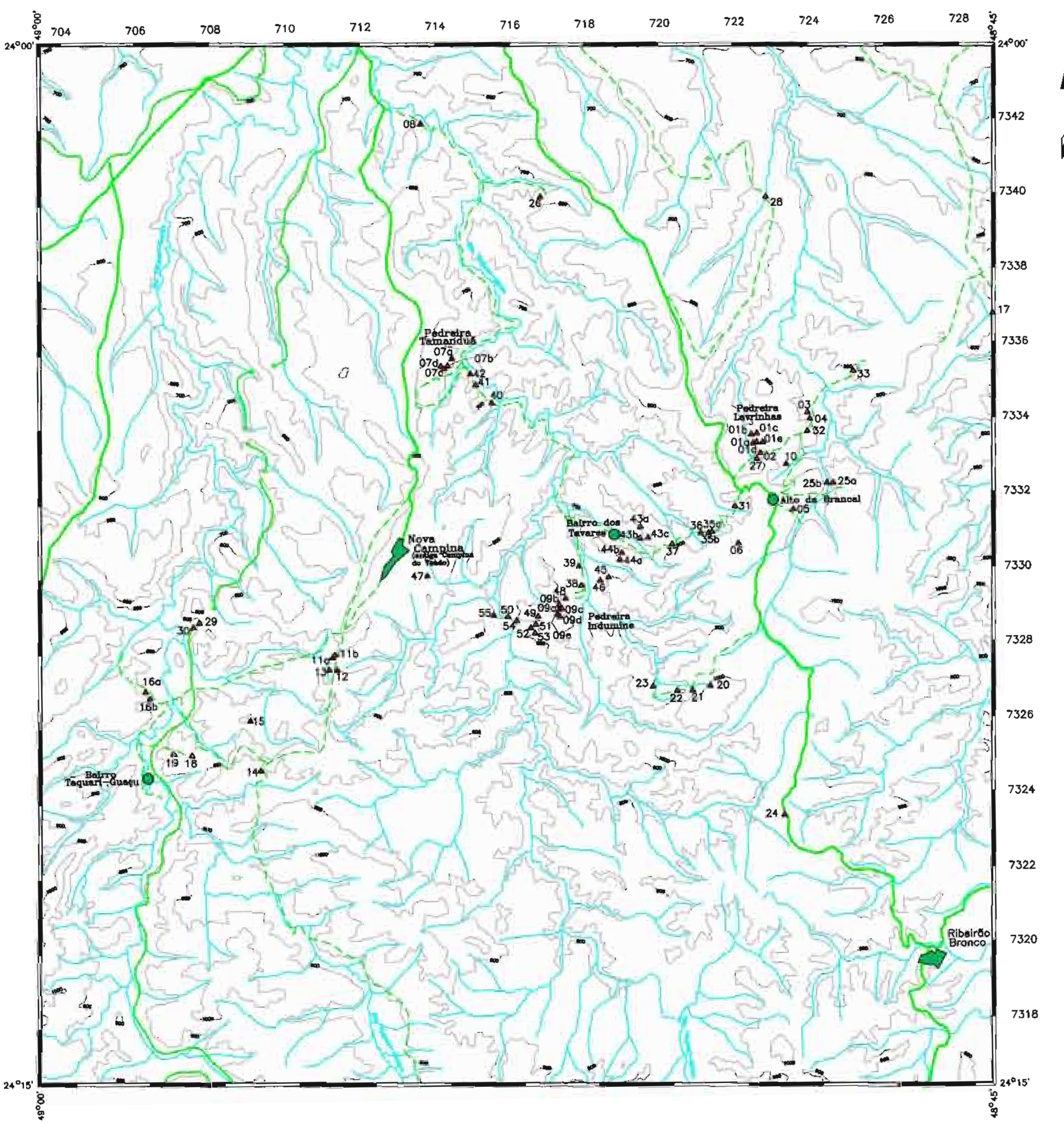

LEGENDA

A Ponto descrito

Ocorrennclas de estromatolitos

02 a 27 - Pedreiras abandonadas da Lavrinhos

09a,b,c,d - Pedreira Indumine

11 - Pedrese abandonada im Nora

17 - Pedreira abandonada na Faz. Santo Antonio

19 - Pedretra abandonada ao Basirro Tloqunn-Guaçu

(I)

44a,b- Pedreira abandonada Chiquinho de Earros

- Curvas de nivel

Estradas principais

Estradas secundarias

Estradas de ferro

F Drenagens

Vidades

- Bairros e vilas

ion

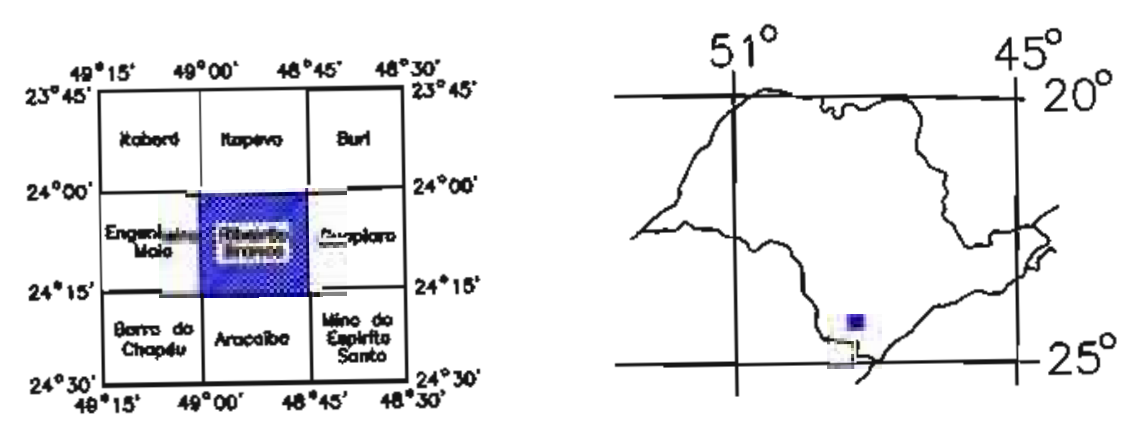

Figura 18: MAPA DE PONTOS William Sallun Filho (1999)

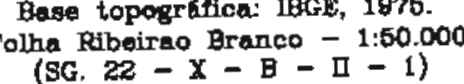




\subsubsection{Pedreira Lavrinhas - LAV (Pontos 02 e 27)}

A frente ativa da Pedreira Lavrinhas (Companhia de Cimento Portland Itaú) localiza-se na porção centro-leste da área, a leste da estrada Itapeva-Ribeirão Branco (ponto 01) (Est. III-A e B). Esta frente não possui estromatólitos e é composta de metacalcários dolomíticos estratificados com intercalações de margas (Est. III-A; I-F). A algumas dezenas de metros a sul e sudeste desta frente existem algumas frentes abandonadas, quase encostadas umas nas outras (Est. III-A). Destas frentes abandonadas foram visitadas duas, os pontos 02 (antiga frente 5) e 27, mas para análise dos estromatólitos (baseada essencialmente em amostras já coletadas) foram consideradas todas as frentes, conjuntamente. O acesso a estas frentes é feito por um estrada de terra a partir da estrada Itapeva-Ribeirão Branco, a cerca de $2,5 \mathrm{~km}$ a $S$ da entrada da frente ativa da Lavrinhas.

O ponto 02 consiste de uma pequena frente abandonada composta por metacalcários dolomíticos cinza claros, estromatolíticos na maior parte, bastante fraturados, e com acamamento pouco evidente. O acamamento é mais nítido onde não ocorrem estromatólitos, no lado SW da pedreira com metacalcários estratificados com atitude de N50E/70-80NW. Os metacalcários estratificados recobrem, estratigraficamente os metacalcários estromatolíticos, inclusive daqueles da pedreira ativa da Lavrinhas (Figura 19).

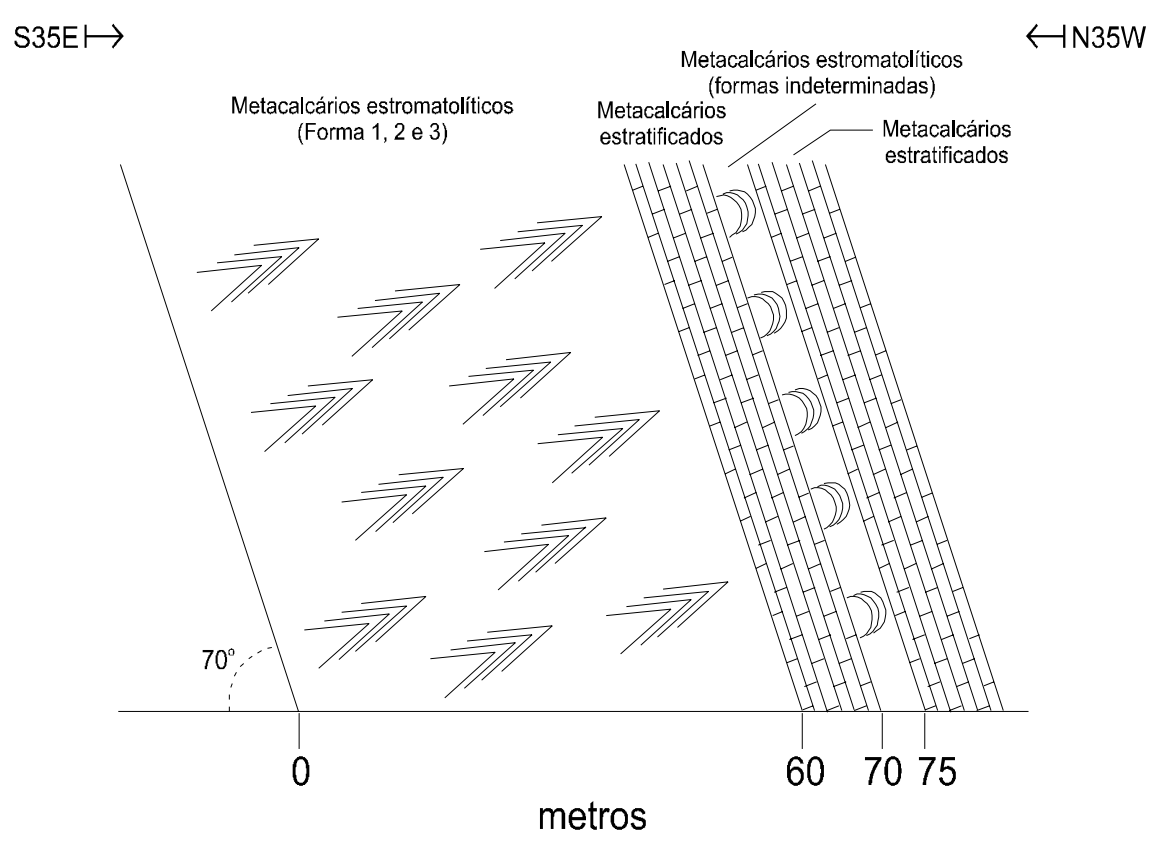

Figura 19: Esquema da estratigrafia de LAV, elaborado por T. R. Fairchild em 1980 (inédito). 
Atualmente é muito difícil ver as estruturas estromatolíticas nesta pedreira porque a pequena quantidade de matéria orgânica que parece ressaltar a laminação original vem se oxidando, restando poucas boas exposições. Nestes pontos é difícil amostrar por se tratarem de faces lisas e estruturas estromatólitos decimétricas.

Os estromatólitos que ainda se pode ver são formas colunares cônicas grandes atribuíveis a Conophyton (Forma 1) (Est. VI) vistos em planta e em perfil no centro da pedreira. Apresentam uma alternância de porções de tonalidades cinza bem claro e cinza médio. O material entre as colunas também é cinza médio a escuro. Ocorrem quase encostados uns nos outros, havendo inclusive coalescência de formas, aparentemente nas margens de bioermas (Est. VI-A a E). O eixo das colunas estão orientadas com direção N20E, com mergulhos de $40^{\circ}$ para SW, com o topo (normal) apontando para NE.

O próprio pacote estromatolítico parece ocupar toda a extensão lateral de aproximadamente 70 metros da pedreira, e como visto na Figura 19, pode ter alcançado cerca de 50 metros de espessura.

Outras duas formas de estromatólitos, também colunares (Forma 2, Est. X-A, B, C, F, G, H, I; e Forma 3, Est. XI-E, F, H), mas bem menores (centimétricos), antigamente eram observados num único ponto desta pedreira. Sua laminação pode ser muito convexa a parabólica mas não chega a ser cônica, são ramificados, e possuem contornos transversais alongados. Chamam a atenção os limites bruscos e o paralelismo das colunas, que, por sinal, são muito próximos entre si.

Apesar dos contornos e da laminação estromatolítica quase apagados nesta pedreira, este ponto representa, atualmente, a melhor exposição de estromatólitos nos metacalcários dolomíticos da região.

A outra frente abandonada (ponto 27) localiza-se a uns 500 metros a sul do ponto anterior. Esta pedreira, bastante deteriorada, são raros e mal preservados os estromatólitos ali presentes em blocos soltos. 
ESTAMPA III - Pedreira Lavrinhas

A - Vista geral para leste mostrando a frente ativa (Ponto 01), e as frentes abandonadas ao redor (pontos 02 e 27; indicadas pelas setas).

B - Detalhe da frente ativa (indicada pela seta vazada em A), visto para noroeste mostrando um corte com metacalcários estratificados. 
4

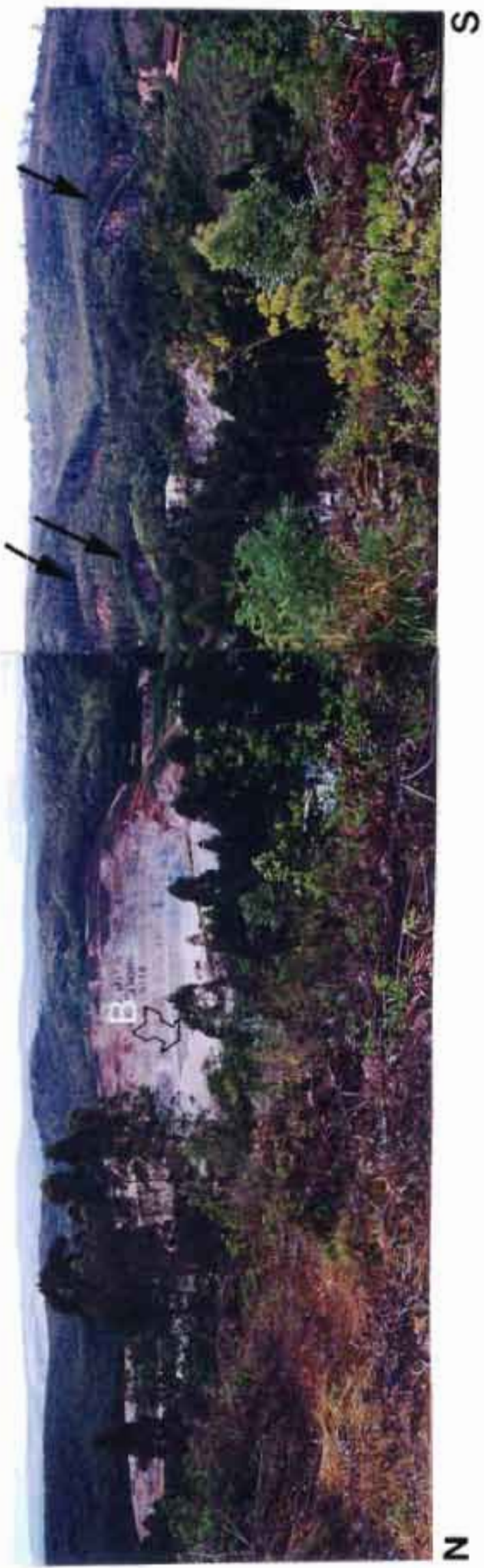

$\infty$

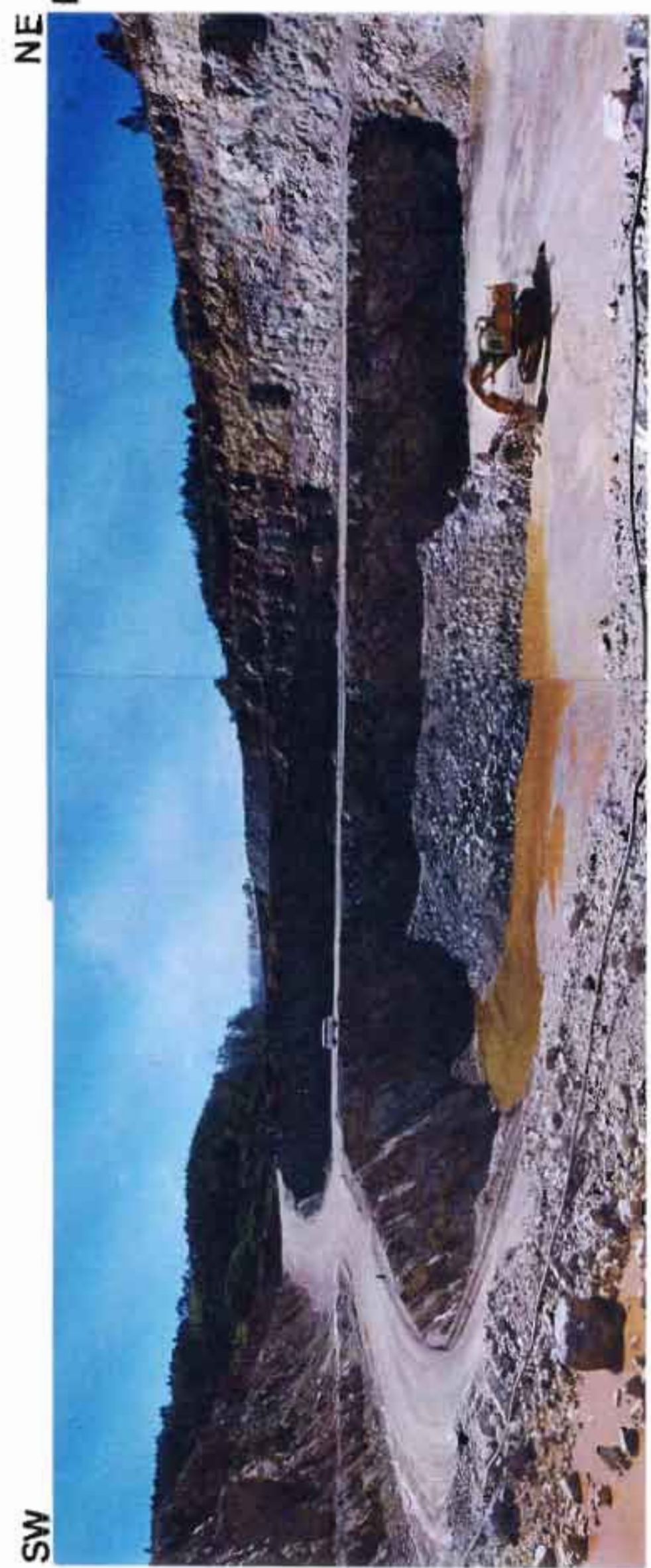




\subsubsection{Pedreira Indumine - IND (Ponto 09)}

A Pedreira Indumine (Companhia Minas-Oeste) é uma pedreira ativa, de orientação $\mathrm{N} 30 \mathrm{E}$, que corta um morro, na porção central da área a aproximadamente $6 \mathrm{~km}$ a SW de LAV (Est. IV-A). Consiste de várias frentes (bancadas) enumeradas neste trabalho de $0 \mathrm{a}$ 4, da mais baixa para a mais alta, e também de NE para SW.

Nesta pedreira ocorrem metacalcários calcíticos cinza escuros a negros, bastante argilosos e foliados, muito distintos dos dolomitos claros da Pedreira Lavrinhas. O corpo metacalcário em exploração é composto essencialmente de estromatólitos, representando, pois, um grande bioerma (Est. IV-B e C). Neste ponto, as superfícies intemperisadas, onde a laminação e o sedimento intercolunar estão ressaltados (Est. VIIA, C e G), permitem as melhores observações. Em superfícies frescas praticamente não se pode diferenciar os estromatólitos do sedimento intercolunar (Est. IV-D).

Os estromatólitos foram deformados dúctil e ruptilmente, sem, contudo destruir sua laminação. As margens e as formas das colunas, entretanto, foram afetadas, significativamente, como será visto em mais detalhe no Capítulo 6.

Compreendem colunas retas (agora deformadas) e praticamente todas coniformes atribuíveis a Conophyton (Forma 1), que chegam a atingir vários metros de altura. As colunas estão alinhadas a N50E, com mergulho de $40^{\circ}$ para SW e topo (normal) apontando para NE (Est. IV-B e D). Algumas amostras coletadas foram classificadas posteriormente, como forma 3 . No topo da seção ocorria antigamente uma forma rara ramificada (Forma 5), em uma trecho já lavrado (Figura 20).

Na seção esquemática levantada por T.R. Fairchild em 1976 (Figura 20), tem-se a sequência desde os filitos, na base, passando por metacalcários arenosos e no topo metacalcários estromatolíticos recobertos por metarenitos finos. O pacote estromatolítico alcança no mínimo 20 metros de espessura. O que se observa atualmente é que na porção leste da pedreira ocorre o contato com filitos (Est. IV-E) que parece estar por cima dos metacalcários. Filitos também ocorrem na porção SW, sendo que neste ponto é possível observar que eles recobrem os metacalcários, em contato aparentemente gradual.

Esta pedreira é o melhor ponto para estudar os estromatólitos nos calcários calcíticos da região. 


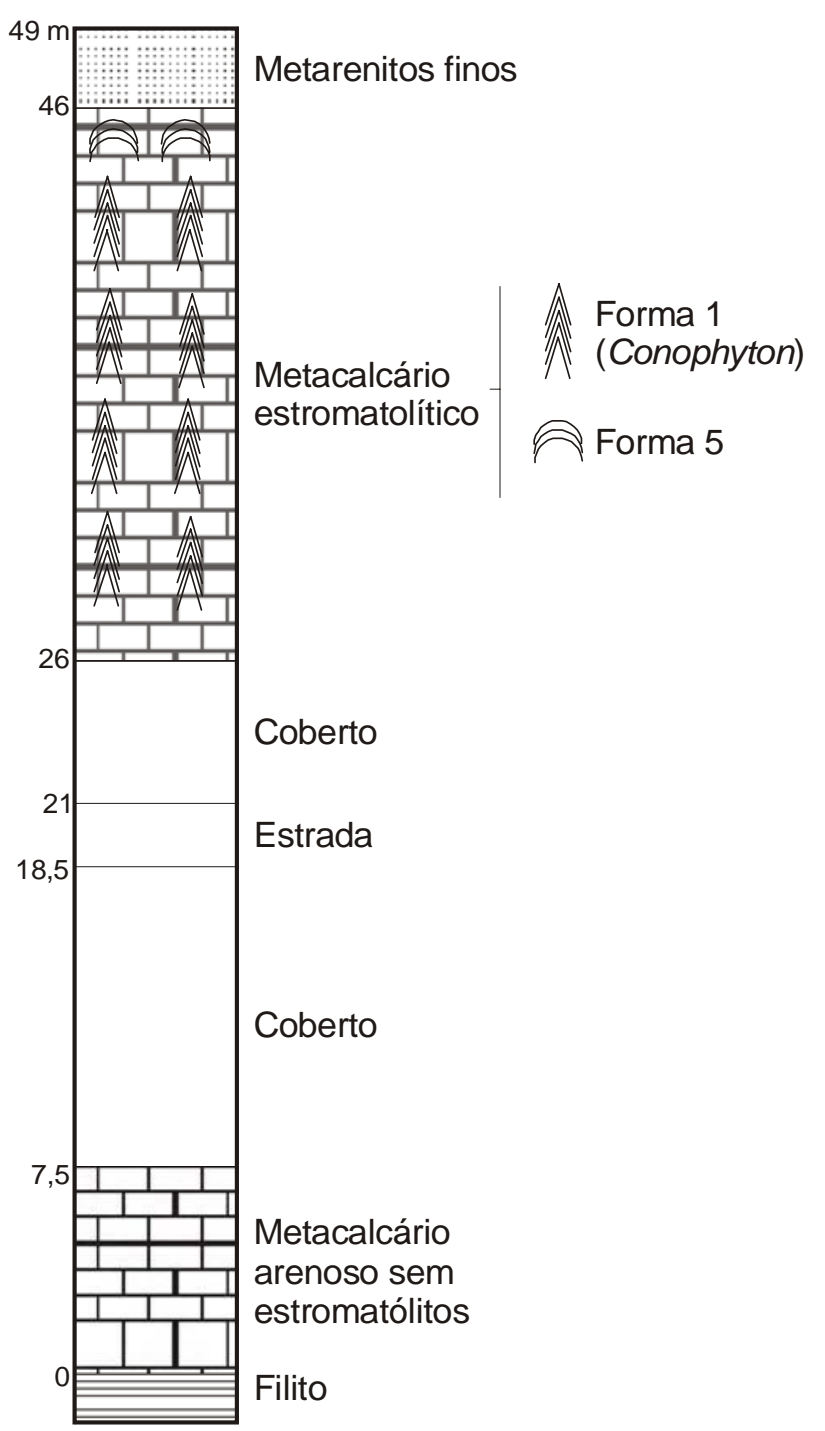

Figura 20: Seção esquemática na pedreira Indumine (IND), baseada em T. R. Fairchild em 1976 (inédito), com modificações. 
ESTAMPA IV - Pedreira Indumine (IND)

A - Vista para SW, da pedreira Indumine atualmente.

B - Vista geral para SW de um grande bioerma, composto por estromatólitos, principalmente Conophyton. Este afloramento já foi lavrado. Fotografia tomada por T.R. Fairchild, em 1976.

C - Desenho esquemático da fotografia de $B$, destacando as silhuetas das colunas mais evidentes.

D - Estromatólitos em corte fresco. As colunas exibem orientação N50E, com topos apontando para NE (indicada pela seta). A barra de escala no centro foto corresponde a $30 \mathrm{~cm}$.

E - Borda SE da pedreira onde ocorre o contato entre metapelitos (à esquerda) e os metacalcários estromatolíticos (à direita). 

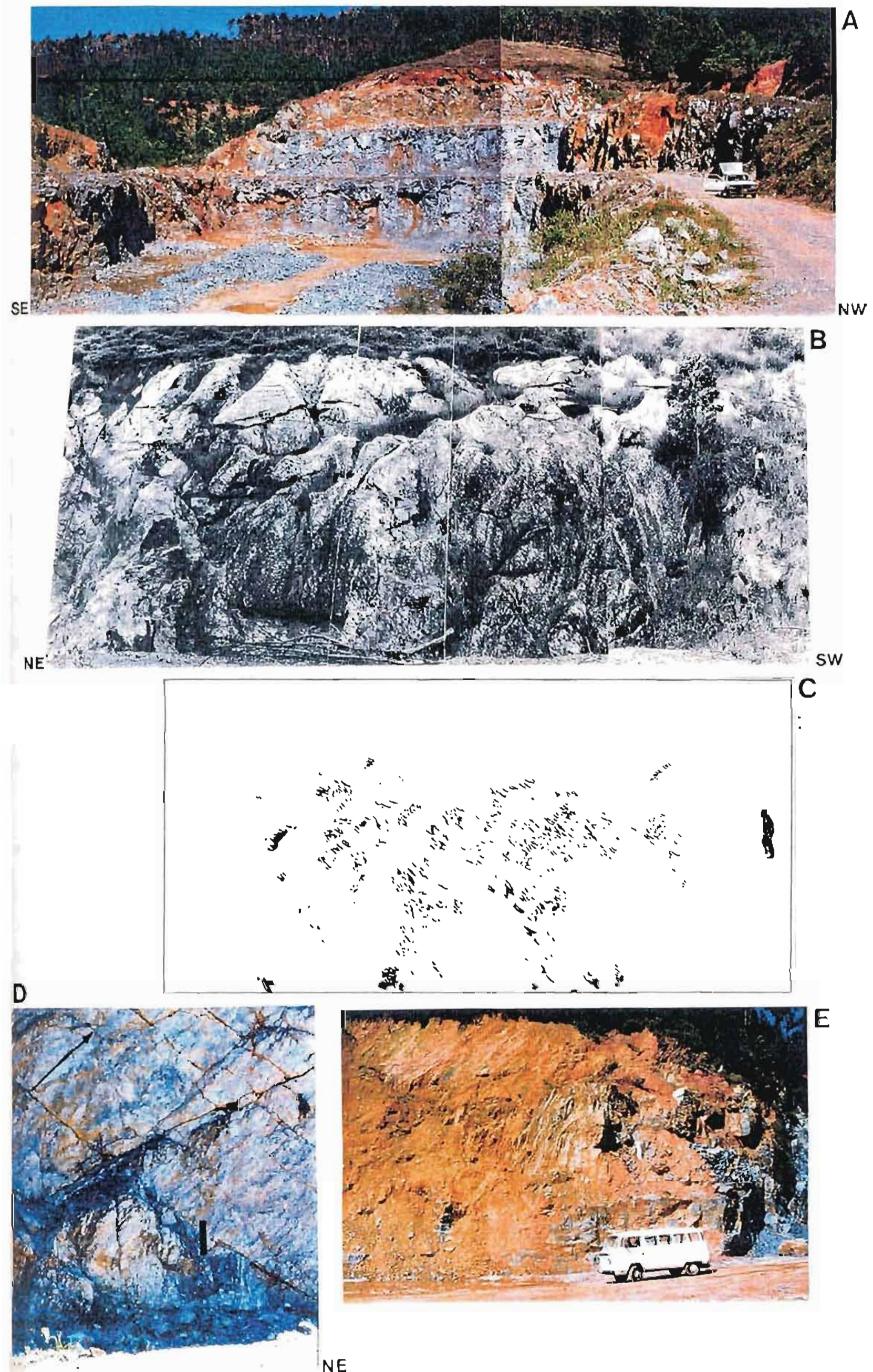


\subsubsection{Frente em Nova Campina - NCM (Ponto 11)}

Localiza-se a aproximadamente $2 \mathrm{~km}$ a SW da cidade de Nova Campina, na margem oeste da estrada, cerca de $13 \mathrm{~km}$ a SW de LAV, e trata-se de uma frente abandonada., aparentemente a localidade 1 de Almeida (1944). Consiste de dois pequenos cortes (cerca de 10 metros de extensão cada), um ao lado do outro, compostos de metacalcários dolomíticos cinza-claros, amarelados pelo intemperismo, sem acamamento evidente. No primeiro corte (Ponto 11a), mais a sul, ocorrem alguns estromatólitos colunares, muito mal preservados, de aproximadamente $7,5 \mathrm{~cm}$ de diâmetro. Seus eixos estão orientados N-S, mergulhando de $40^{\circ}$ para sul e com topo (normal) apontando para norte.

O outro corte (Ponto 11b), a aproximadamente 15 metros a norte, apresenta alguns estromatólitos colunares de $10 \mathrm{~cm}$ de diâmetro mais bem preservados. Estes estromatólitos revelaram-se colunares não ramificados, retos, com limites muito bem definidos pela tonalidade cinzenta mais clara do que o sedimento entre as colunas. Possuem laminação muito fina, pouco convexa, e estão pouco deformados.

Os estromatólitos observados aqui consistem da Forma 3 e algumas amostras soltas da Forma 2, que se assemelham aos estromatólitos desta mesma forma observados em LAV.

\subsubsection{Pedreira Itanguá - ITN (Ponto 16)}

Localizada a norte do Bairro Taquari-Guaçu, próximo a margem oeste do Rio Taquari-Guaçu, a cerca de $18 \mathrm{~km}$ a SW de LAV, esta pedreira é composta de duas grandes frentes (de aproximadamente 50 metros de extensão cada) abandonadas. A primeira frente situada a noroeste (Ponto 16a) é composta de metacalcários dolomíticos cinza claros, geralmente maciços, por vezes esbranquiçados, e estratificados, com atitude de N30-45E/55SE. Na porção NW desta frente ocorrem, em apenas um ponto, pequenas estruturas colunares, que se assemelham a estromatólitos, posicionados diretamente sobre um metacalcário estratificado, de onde se expandem tanto vertical quanto lateralmente. Estes estromatólitos pertencem a Forma 4.

A outra frente situada a sudeste (Ponto 16b) também é composta por metacalcários dolomíticos cinza maciços, um pouco mais escuros, mas não foram observados estromatólitos. 
Não foi possível coletar amostras, porque a única estrutura observada se encontrava em uma face lisa. Portanto a análise destes estromatólitos está restrita aos dados de campo (Est. XII-A e B).

\subsubsection{Pedreira na fazenda Santo Antônio - FSA (Ponto 17)}

Esta antiga frente de metacalcário dolomítico bandado preto, branco e vermelho, explorado para rocha ornamental está situada dentro da Fazenda Santo Antônio, no ponto mais nordeste da área de estudo, a cerca de $6 \mathrm{~km}$ a NE de LAV. Apresenta dois cortes verticais planos de direção N-S, feitos por fio de aço utilizado durante a extração de blocos, com um córrego passando entre eles. O maior (15 m) e mais antigo deles está coberto por "limo" (algas, musgos, sujeira, etc.) é de difícil acesso por causa da grande quantidade de blocos soltos logo à sua frente, que foi estudado por Fairchild e Theodorovicz (1989). O corte menor (10 m), mais recente e mais limpo, permitiu excelentes observações (Est. V-A). Os cortes observados na pedreira são oblíquos tanto aos eixos dos estromatólitos, quanto ao bandamento.

Os carbonatos compreendem metacalcários dolomíticos, intensamente deformados e recristalizados (mármore), com bandamento orientado a N65E/65SE e as faixas vermelhas estromatolíticas menos recristalizadas num arranjo que lembra boudinagem (Est. V-A a G).

Os estromatólitos encontram-se densamente agrupados e são retos, colunares, aparentemente não ramificados e com margens preservadas (Est. V-F e G). Exibem no máximo $10 \mathrm{~cm}$ de largura e no mínimo $20 \mathrm{~cm}$ de altura (originalmente poderiam ser maiores, mas estão interrompidos pela deformação). A laminação é fina (milimétrica) com relevo sinótico relativamente alto e forma cônica, o que difere daqueles vistos no campo, que possuíam relevo baixo provavelmente por estarem em corte oblíquo. Apesar de não ter sido observada em campo, a presença de zona axial nestes estromatólitos permite atribuí-los a Conophyton (Forma 1). 
ESTAMPA V - Estromatólitos da Fazenda Santo Antônio (FSA)

A - Vista geral do principal corte estudado da pedreira.

B, D -Detalhes do corte em A (ver setas em A). Note a alternância de bandas vermelhas com bandas preto e brancas, num arranjo de boudinagem. Os estromatólitos ocorrem nas bandas vermelhas. Em B a escala corresponde a $13 \mathrm{~cm}$.

C, E - Desenhos esquemáticos das fotografias B e D, respectivamente. As linhas mais espessas representam os limites das colunas e as pontilhadas traços de fraturas. Em $\mathrm{C}$ a escala corresponde a $13 \mathrm{~cm}$.

F - Boudin de uma banda vermelha com estromatólitos. A laminação está ressaltada com giz branco e os limites das colunas em preto. Nos limites do boudin e nas bandas preto e brancas adjacentes os estromatólitos deformados e/ou fragmentos estirados. A escala corresponde a $13 \mathrm{~cm}$.

G - Desenho esquemático da fotografia F. As linhas mais espessas representam os limites das colunas, a demarcação em torno delas o sedimento intercolunar, e as linhas pontilhadas traços de fraturas. A escala corresponde a $13 \mathrm{~cm}$. 

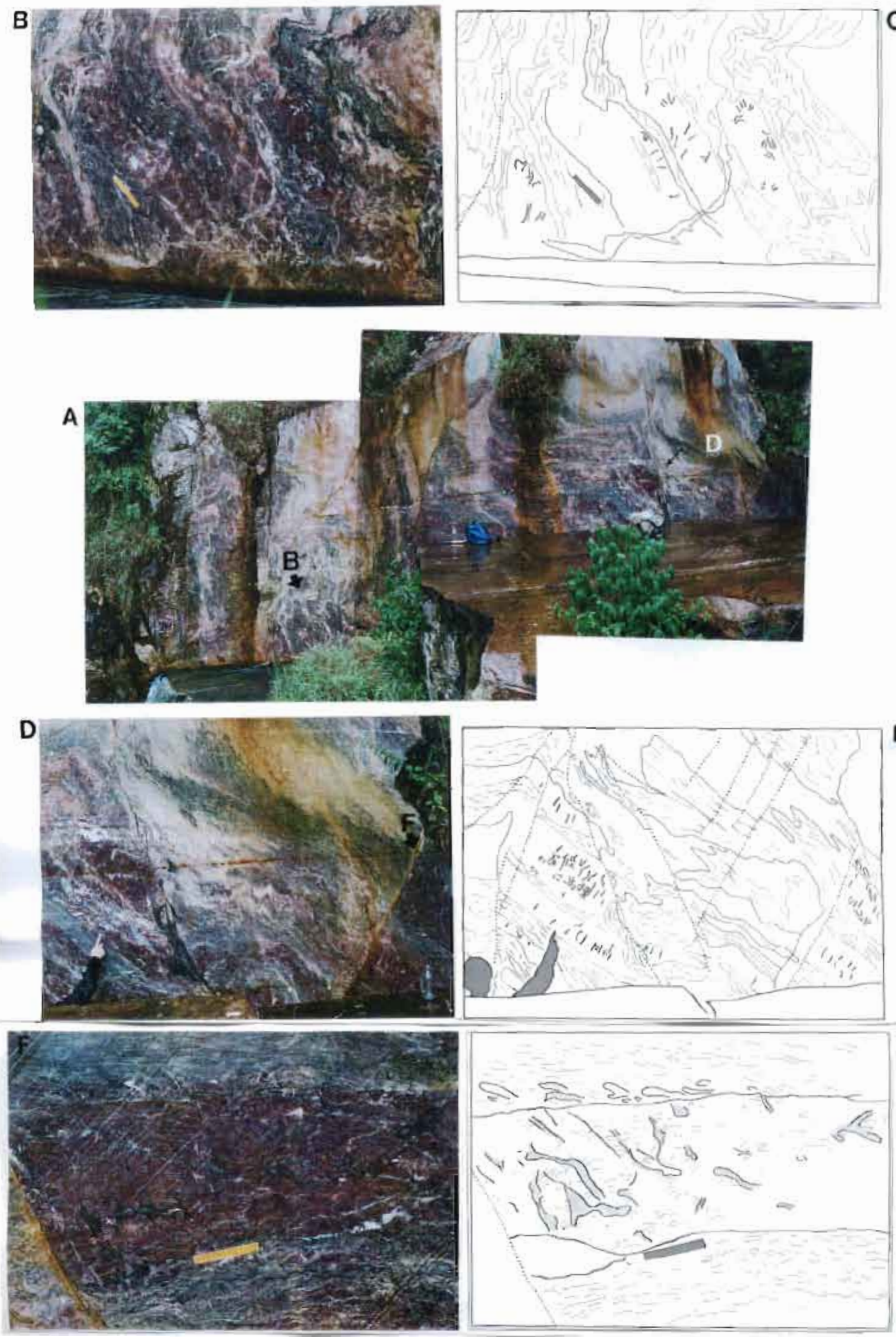


\subsubsection{Pedreira no bairro Taquari-Guaçu - TGU (Ponto 19)}

Localizada no bairro Taquari-Guaçu, próximo a margem leste do Rio TaquariGuaçu, a aproximadamente $18 \mathrm{~km}$ a SW de LAV, encontra-se uma pedreira abandonada de metacalcários dolomíticos brancos, creme e cinza claros. As poucas amostras obtidas foram coletadas como fragmentos soltos do chão.

No corte da pedreira ocorrem alguns raros estromatólitos colunares, retos, não ramificados, mal preservados, com cerca de $13 \mathrm{~cm}$ de largura e de, no mínimo, $30 \mathrm{~cm}$ de altura, com contornos ora bem ora mal definidos e laminação ora fina, ora mais grossa onde recristalizada. Apresentam relevo sinótico alto, laminação muito convexa e contorno em planta elíptico. São atribuídos à Forma 3.

A análise destes estromatólitos é dificultada pela deterioração da frente da pedreira e pelo número baixo e má qualidade de preservação nas amostras.

\subsubsection{Pedreira na estrada Brancal-Indumine - IB1 (Ponto 31)}

Está localizada nas cabeceiras do Córrego da Boa Vista, na porção centro-leste da área, em uma pequena elevação do lado NW da estrada de terra NE-SW que vai do Alto da Brancal até a pedreira Indumine. Está a cerca de $2 \mathrm{~km}$ a SSW de LAV e $5 \mathrm{~km}$ a NE de IND. Existe uma pedreira abandonada, retomada pela vegetação, onde ocorrem metacalcários dolomíticos cinza claros a creme, parcialmente silicificados por sílica incolor a cinza clara tanto concordante à laminação estromatolítica como em fraturas.

Lá ocorrem estromatólitos colunares de 7 a $15 \mathrm{~cm}$ de diâmetro, com laminação fina muito convexa a parabólica, margens retas, relevo sinótico alto e contornos em planta elípticos, atribuídos as formas 2 e 3. A preservação é relativamente boa com a laminação e as margens muito nítidas. As colunas têm eixos com direção N70W, mergulho de $30^{\circ}$ para SE, com o topo (normal) para NW.

\subsubsection{Frente na estrada Brancal-Indumine - IB2 (Ponto 35)}

A aproximadamente $1,5 \mathrm{~km}$ a SW de IB1, na estrada de terra NE-SW que vai do Alto da Brancal até a pedreira Indumine, a cerca de $3 \mathrm{~km}$ a SSW de LAV e $4 \mathrm{~km}$ NE de IND, ocorrem, na base da Serrinha (serra constituída de metacherts, Est. I-D), dois pequenos cortes ESE-WNW (com aproximadamente 7 metros cada) abandonados de metacalcário dolomítico predominantemente cinza claro, com camadas cinza escuras. 
Ocorrem estromatólitos no primeiro corte (Ponto 35a), mais a ESE, apenas em um local da frente. O outro corte (Ponto 35b), ao lado do primeiro, mais a WNW, é constituído por metacalcários dolomíticos cinza claro maciços, sem estromatólitos evidentes.

Nesta frente os metacalcários estão muito recristalizados e as estruturas estromatolíticas muito mal preservadas, com pouca definição das colunas e laminação grossa.

\subsubsection{Pedreira Chiquinho de Barros - CHB (Ponto 44a, b)}

Esta pedreira está localizada na porção central da área, a aproximadamente 1,5 km a NE de IND, na estrada de terra, atualmente intransitável, que sai da estrada BrancalIndumine na altura do bairro dos Tavares em direção a Indumine.

São duas frentes abandonadas, sendo uma frente (Ponto 44a), afastada da estrada, situada logo acima da outra (Ponto 44b), menor, encostada na estrada de terra. O acesso às frentes é difícil, pois foram retomadas por vegetação.

São metacalcários calcíticos cinza escuros estromatolíticos iguais aos que afloram em IND. Pode-se observar estromatólitos colunares em algumas partes das frentes, especialmente na segunda, mas não foi possível fazer descrições mais detalhadas. Mas a análise dos estromatólitos desta localidade foi possível através de amostras, descrições e fotografias feitas por T.R. Fairchild no passado.

\subsection{Modo de ocorrência}

As ocorrências podem ser agrupadas da seguinte forma (Tabela 5):

1- Estromatólitos em metacalcários dolomíticos cinza claro a esbranquiçado; pouco deformados; laminação pouco nítida mas colunas geralmente bem definidas: LAV, NCM, ITN, TGU, IB1 e IB2.

2- Estromatólitos em metacalcários calcíticos cinza escuros a pretos, localmente foliados; deformados, mas pouco recristalizados; laminação e margens dos estromatólitos bem nítidos, embora comumente tectônicas (cisalhadas): IND e CHB.

3- Metacalcários dolomíticos bandados com porções estromatolíticas avermelhadas, menos deformados, intercaladas a porções bandadas, preto e branco e deformadas: FSA. 
Não é fácil determinar o modo de ocorrência dos estromatólitos na região, ou seja, se constituíram biostromas ou bioermas, por várias razões. Primeiro, afloram em poucos lugares na área, pois existe densa cobertura vegetal. Portanto, as observações foram restringidas a algumas pedreiras, a maioria já abandonada e algumas retomadas pela vegetação. Segundo, há falta de definição clara da estratificação nos metacalcários dolomíticos, inclusive, em superfícies intemperisadas. No caso de metacalcários dolomíticos estromatolíticos, isto também ocorre e é agravado quando se trata de superfície de pedreiras abandonadas há muito tempo, pois ocorre uma perda de definição com o passar do tempo. Terceiro, complicações tectônicas (principalmente as falhas) geram dúvidas quanto a continuidade das camadas, dificultando a interpretação da geometria original dos corpos estromatolíticos.

Mesmo assim, pode-se distinguir, tentativamente, bioermas de dois tipos, um tabular devido a uma maior extensão lateral e outro dômico/lenticular, devido à pequena extensão lateral (Tabela 5). Em várias localidades não foi possível definir o modo de ocorrência devido à má exposição das camadas ou dos estromatólitos.

\begin{tabular}{|l|c|c|}
\cline { 2 - 3 } \multicolumn{1}{c|}{} & \multicolumn{2}{c|}{ Modo de ocorrência } \\
\cline { 2 - 3 } \multicolumn{1}{c|}{} & Rocha: metacalcário & Bioerma \\
\hline LAV & Dolomítico & Tabular \\
\hline IND & Calcítico & Dômico/lenticular \\
\hline NCM & Dolomítico & Tabular \\
\hline ITN & Dolomítico & Tabular \\
\hline FSA & Dolomítico & Não determinado \\
\hline TGU & Dolomítico & Tabular \\
\hline IB1 & Dolomítico, parcialmente silicificado & Não determinado \\
\hline IB2 & Dolomítico & Não determinado \\
\hline CHB & Calcítico & Dômico/lenticular \\
\hline
\end{tabular}

Tabela 5: Modo de ocorrência dos estromatólitos na área de estudo.

Os locais de melhor observação dos bioermas eram em LAV, onde o pacote estromatolítico alcançou pelo menos 50 metros de espessura (Figura 19) e em IND, com cerca de 20 metros, embora a exploração desta mina tenha destruído o que era o melhor afloramento da região (Figura 20 e Est. IV-B e C). 


\subsection{Caracterização dos morfotipos}

\subsubsection{Descrição das formas}

\section{Forma 1 - Estromatólitos colunares coniformes (Conophyton)}

A Forma 1 se caracteriza por sua laminação cônica com zona axial e pelo seu tamanho centimétrico, tanto na altura quanto no diâmetro. São estromatólitos coniformes colunares não ramificados, cuja laminação cônica varia em perfil longitudinal de parabólica a pontiaguda, na medida que se aproxima da zona axial. A zona axial compreende um feixe central estreito formado pelo empilhamento das pontas, normalmente mais espessas, de sucessivas lâminas cônicas. Sua presença é uma das características essenciais do grupo Conophyton.

É possível inferir se o estromatólito é coniforme também em bons cortes transversais pelo diâmetro, cada vez mais diminuto dos traços circulares a elípticos da laminação, conforme ilustrado na Figura 21.

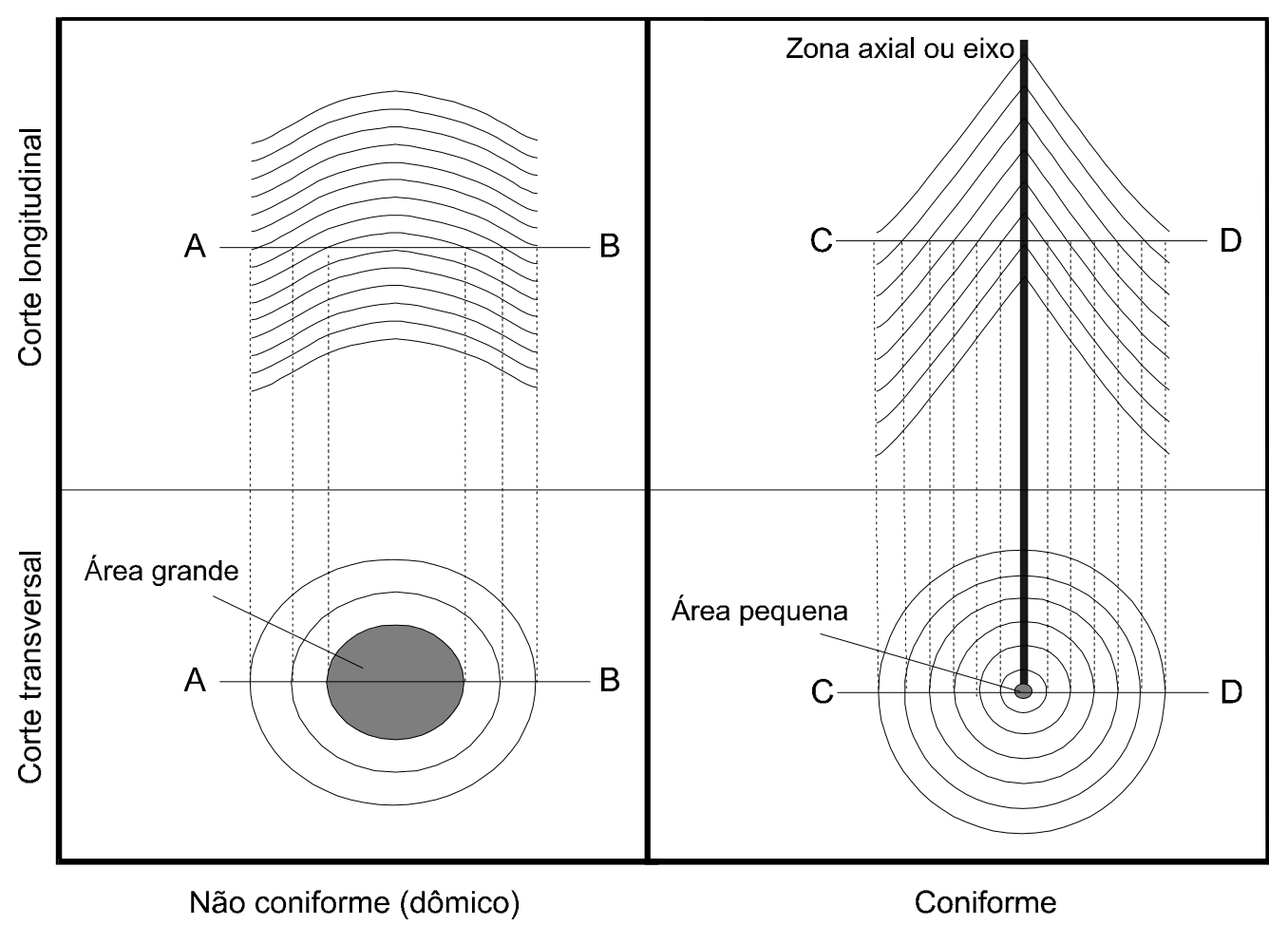

Figura 21: Critérios para distinguir estromatólitos coniformes de outros tipos.

Em FSA onde a laminação chega a ser pontiaguda, uma zona axial foi descrita em apenas uma amostra (FSA-11), discutida mais adiante. Com base nisto Fairchild \& Theodorovicz (1989) comparam estes estromatólitos com o Conophyton de LAV e IND. 
Também em IB1 ocorrem algumas formas que parecem ser cônicas (parabólicas pontiagudas) mas sem uma zona axial evidente, não sendo possível atribuí-las a Conophyton.

Os estromatólitos coniformes formam os principais bioermas na área (LAV, IND e CHB). Em IND e CHB ocorrem formas semelhantes, que diferem das formas em LAV.

Tabelas 6 e 7 quantificam o material disponível em laboratório para caracterização da Forma 1.

\begin{tabular}{|c|l|c|}
\hline Localidade & \multicolumn{1}{|c|}{ Número das amostras } & Total de amostras \\
\hline LAV & $01,04,08,09,10,16,21,24,25,31,32$ & 11 \\
\hline IND & $05,07,08,09,10,11,15,16,22,23,24,25,28,29,30$ & 15 \\
\hline CHB & 03 & 1 \\
\hline FSA & 11 & 1 \\
\hline
\end{tabular}

Tabela 6: Amostras utilizadas para caracterização da Forma 1.

\begin{tabular}{|c|c|c|c|c|}
\hline Localidade & $\begin{array}{c}\mathrm{n}^{0} \text { de amostras } \\
\text { analisadas na } \\
\text { morfometria }\end{array}$ & $\mathrm{n}^{0}$ de faces & $\mathrm{n}^{0}$ de colunas & $\begin{array}{l}\text { Total de medidas } \\
\text { para morfometria }\end{array}$ \\
\hline$\overline{\text { LAV }}$ & 10 & 62 & 15 & 43 \\
\hline IND & 15 & 108 & & 21 \\
\hline $\mathrm{CHB}$ & 1 & 2 & 1 & 1 \\
\hline FSA & $\bar{E}$ & $\bar{E}$ & $\bar{E}$ & $\bar{\tau}$ \\
\hline
\end{tabular}

Tabela 7: Dados utilizados para morfometria na Forma 1.

A qualidade de preservação para as colunas é classe 2 em LAV e classe 1 em IND (apesar de deformados).

\section{Arranjo das colunas:}

As colunas se apresentam de maneira agregada formando estruturas compostas de indivíduos de diversos tamanhos, podendo haver coalescência, mais evidente em LAV (Est. VI-A a F). Algumas colunas são assimétricas em corte transversal, ou seja, com um lado mais desenvolvido do que o outro (Est. VI-A a F). Ao redor de algumas destas estruturas foi observada uma "capa" apresentando o mesmo tipo de laminação fina que é observada dentro das colunas individuais, que cobria todo o exterior. O diâmetro total destes agregados pode ter chegado a alguns metros, mas não se sabe exatamente as suas dimensões. Isto foi observado principalmente em LAV, mas também foi constatado em um bloco de cerca de 2 metros de comprimento em IND (Est. VI-A a G). Este arranjo 
das colunas é semelhante a algumas estruturas observadas por Donaldson (1976, figuras 2 e 5) no Grupo Dismal Lakes, no Mesoproterozóico do Canadá.

As colunas são paralelas, não ramificadas, com atitude normal (G.1), e estão agrupadas, de forma contígua (H.1) a próxima (H.2) (Est. VI-A; VII-A e E; XIII-A), formando agrupamentos interligados (F.8) (Est. VII-E e H; VIII-G; XIII-A). Devido a deformação em IND e CHB, a orientação original não é mais observada, mas as colunas encontram-se paralelas, orientadas tectonicamente (Est. VIII-B e C).

O espaço intercolunar é pequeno e varia de 0,5 a $2 \mathrm{~cm}$. Quando calculada a razão distância intercolunar vs. diâmetro das colunas, obteve-se um valor muito baixo, menor de 0,1 .

\section{Forma das colunas:}

A colunas são cilíndricas, simples (C.5) (Est. VII-A; VIII-A, B e C; XIII-A), lisas (M.1) (Est. VII-A e B; VIII-A, B, C e E; XIII-A) com contornos transversais geralmente elípticos a oblongos (F.3) (Est. VII-E e F; VIII -G e $H$ ), existindo formas equidimensionais arredondadas/circulares (F.1) (Est. VII-G) a poligonais (F.2) (Est. VII-H).

Em LAV as formas são grandes, com mais geralmente $30 \mathrm{~cm}$ no seu eixo maior em planta, variando entre 10 a $70 \mathrm{~cm}$ (Est. VII-A, E, F, G e H). Em IND e CHB ocorrem formas de 4 a $60 \mathrm{~cm}$ (Est. VIII -D, E, G e H).

A altura das colunas chega a pelo menos 1 metro observado em campo, e deve chegar a bem mais que isto (Est. VII-A; VIII-A e B).

\section{Forma das lâminas:}

O perfil laminar é de modo geral pontiagudo (N.7) (Figura 23 A, E, G e H; Est. VIIA, B e C; VIII -D), mas em cortes axiais demonstra ser pontiagudo com zona axial (N.8) (Figura 23 B, C, D, F e I; Est. VII-D; VIII-E e F). Em LAV o ângulo apical em média (8 medidas) é de $60^{\circ}$, em cortes no eixo maior e de $40^{\circ}$ em cortes no eixo menor (Figura 23 A a D). O ângulo apical em IND em média (9 medidas) é menor, entre $40^{\circ}$ no eixo maior e $20^{\circ}$ no eixo menor, devido ao achatamento tectônico (Figura $23 \mathrm{E}$ a H). Em uma amostra de CHB (CHB-03) (Figura 23 I; Est. VIII -F), muito deformada, este ângulo é muito pequeno, $15^{\circ}$ no eixo menor, com um ângulo calculado (por trigonometria) de apenas $25^{\circ}$ no eixo maior. 
O relevo sinótico é alto, de $20 \mathrm{~cm}$ em formas com cerca de $20 \mathrm{~cm}$ de eixo maior. Considerando um ângulo apical médio de $60^{\circ}$ no eixo maior em LAV, por exemplo, e o tamanho do eixo maior, pode-se calcular o relevo sinótico, como por exemplo, uma forma de $10 \mathrm{~cm}$ de eixo maior teria cerca de $9 \mathrm{~cm}$ de relevo sinótico. Já formas maiores com 70 $\mathrm{cm}$ de eixo maior, poderiam alcançar até $60 \mathrm{~cm}$ de relevo. Em IND foi observada (em campo) uma forma com pelo menos $60 \mathrm{~cm}$ de eixo maior com um relevo sinótico de 60 cm (Est. VIII -D). O relevo sinótico pode ter sido maior até que o próprio diâmetro da coluna.

A zona axial é muito estreita, geralmente de 3 a $4 \mathrm{~mm}$ de largura (Figura 23; Est. VII-D; VIII-E e F; IX-A e B). Excepcionalmente, pode alcançar até $1 \mathrm{~cm}$ (eixo maior), ou, em amostras muito deformadas, apenas $2 \mathrm{~mm}$ (eixo menor) (Figura 23; Est. VIII-F). A partir dos traços axiais, ou seja, as linhas unindo os pontos de maior espessura em lâminas sucessivas da zona axial, pode-se deduzir o grau de herança laminar (Figura 22) e distinguir entre algumas formas de Conophyton. Em amostras de LAV e CHB a zona axial e seus respectivos traços, indicam grau de herança laminar da zona axial alto (R.3) a médio (R.2) (Figura 23 e 24; Est. VII-D; VIII-E e F; IX-A e B).

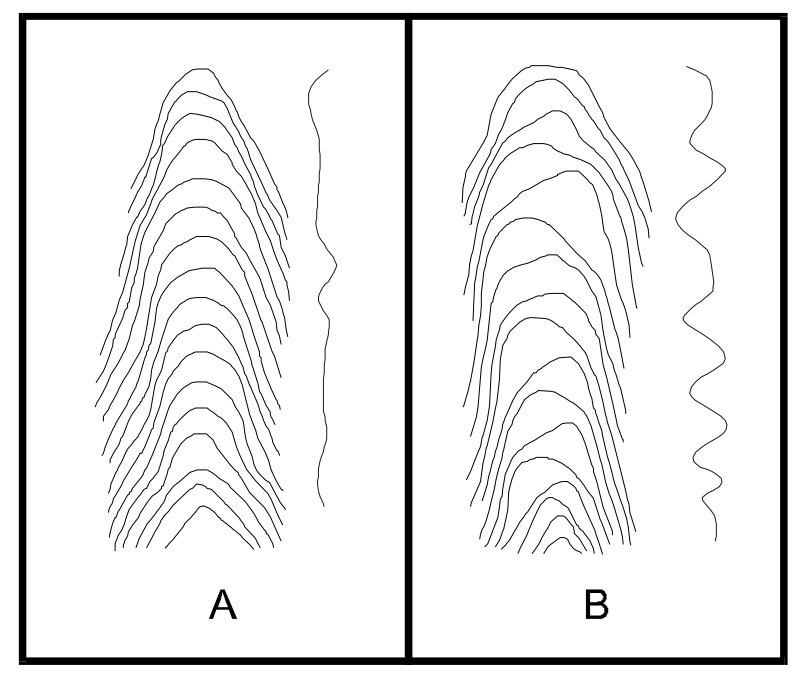

Figura 22: Tipos de zona axial e, à direita de cada uma, os respectivos traços axiais unindo os pontos de maior espessura da laminação (modificado de Walter, 1972). A- alto grau de herança, B- baixo grau de herança. 


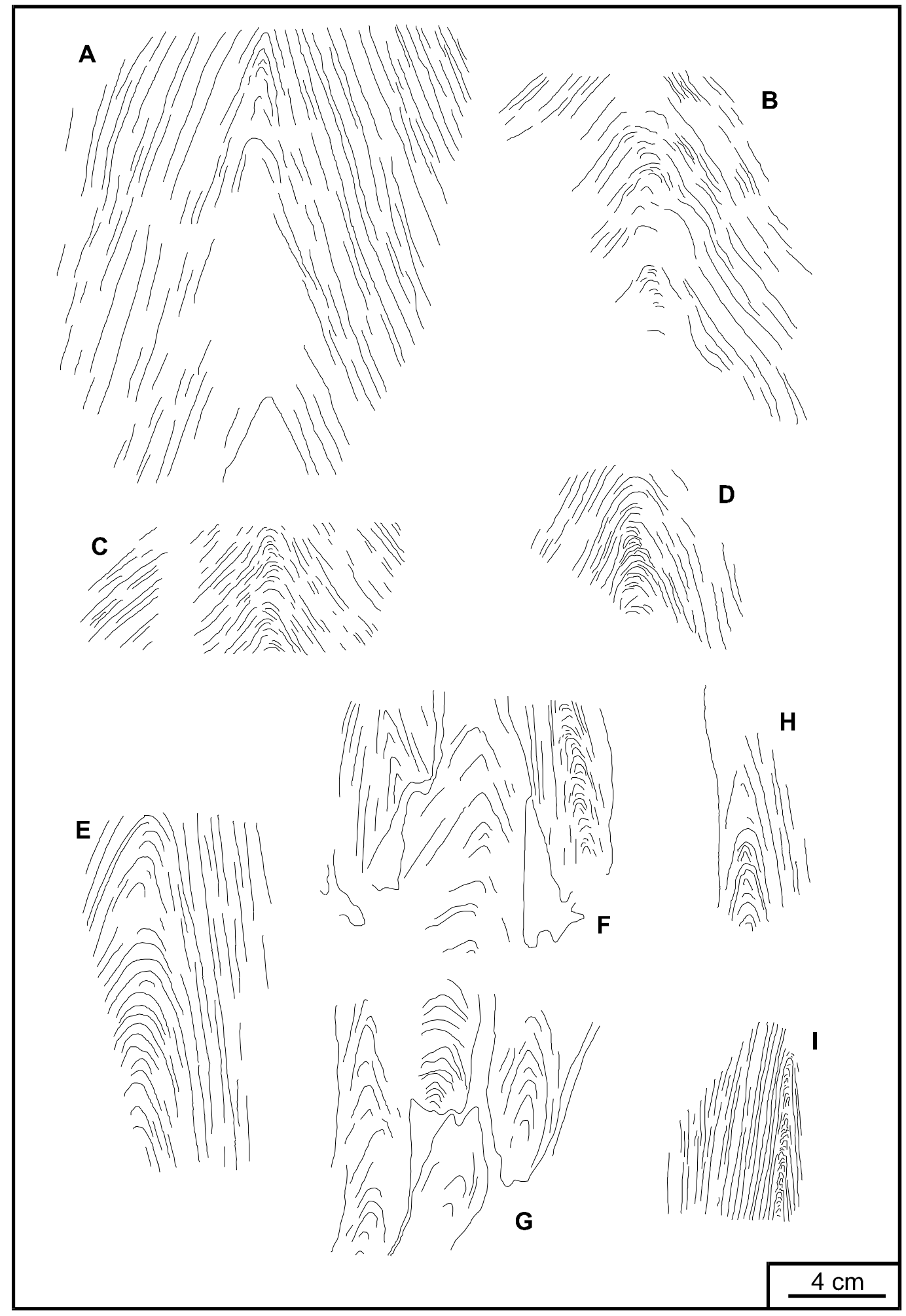

Figura 23: Traços da laminação de amostras da Forma 1 de LAV, IND e CHB em corte longitudinal. Ver detalhes de C, D e I na Figura 24. A escala é igual para todas as figuras. A linha vertical em $\mathrm{H}$ demarca a margem da coluna; da mesma forma os contornos de colunas individuais estão demarcados em F e G. A- LAV-01 (Est. VII-B); B- LAV-16; C- LAV-21 (Est. VII-D); D- LAV25; E- IND-25; F- IND-24 (Est. VIII-E); G- IND-24; I- CHB-03 (Est. VIII-F). 


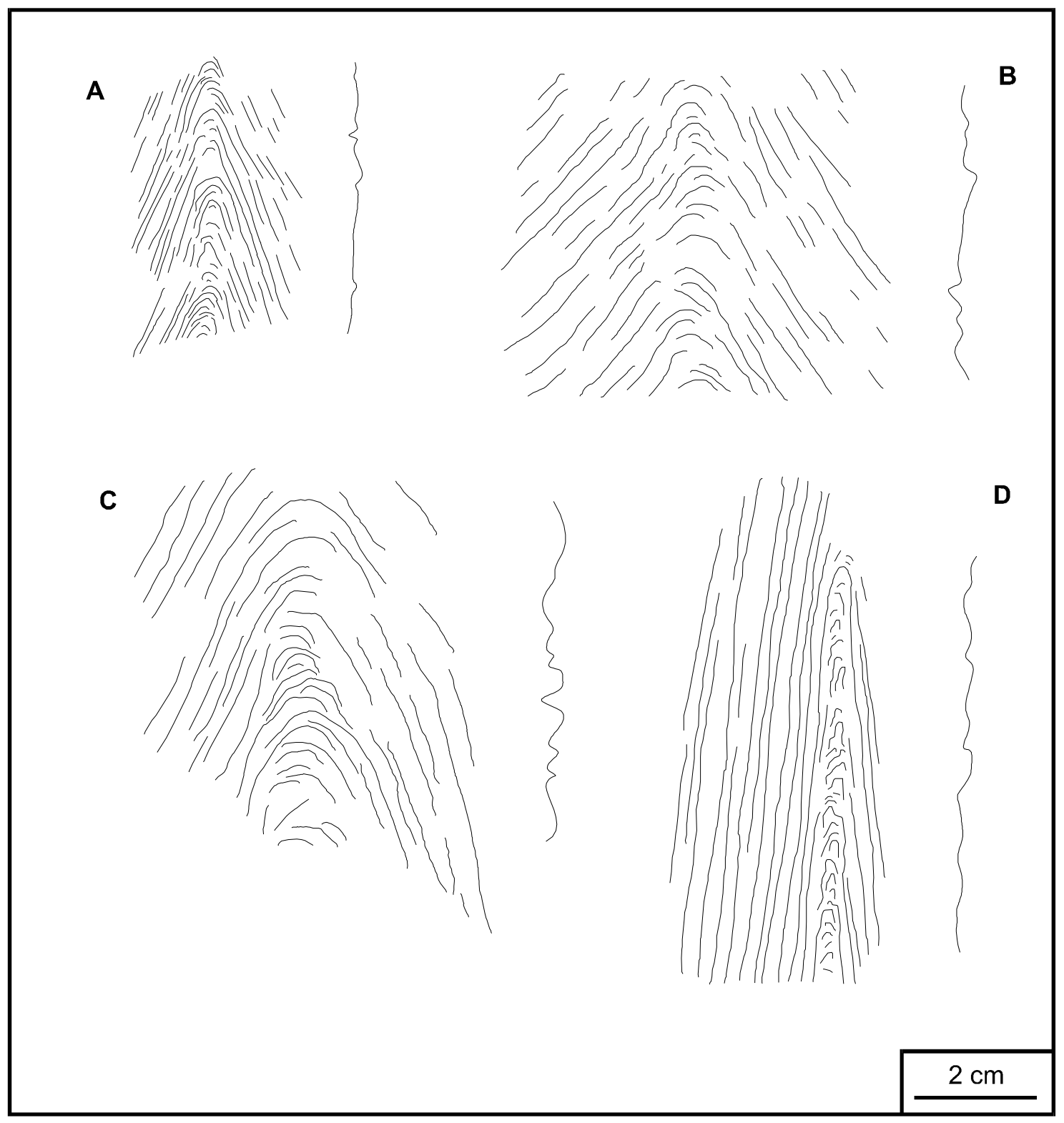

Figura 24: Detalhes da zona axial e seus respectivos traços axiais em amostras da Forma 1 de LAV e CHB. A escala é igual para todas as figuras. A- LAV-32 (lâmina) (Est. IX-A); B- LAV-21

(Figura 23 C; Est. VII-D); C- LAV-25 (Figura 23 D); D- CHB-03 (Figura 23 I; Est. VIII-F). 


\section{Microestrutura:}

A laminação é fina em LAV, mas mal preservada, ressaltando um padrão de "manchas" claras e escuras, concordantes ou discordantes com a laminação (Est. VII-A, $B, D$ a H). Nas porções mais escuras a laminação é melhor definida (Est. VII-B e D). Este padrão decorre das alterações na laminação original devido à dolomitização e/ou à deformação. Em IND/CHB as lâminas também são finas, porém mais nítidas (Est. VIII -D a H). Quanto à laminação em si, tanto em LAV como em IND/CHB observa-se um padrão de alternância sub-milimétrica a milimétrica de lâminas claras e escuras (Est. VII-D e E; VIII -D, E, F e H). Não apresenta ondulação, ou seja, seu grau de curvatura é simples, 0.1 da Figura 16 (Est. VII-B; VIII-C e E).

Em lâminas petrográficas de LAV, apesar da dificuldade de visualizar a laminação em amostras e no campo, observou-se boa preservação, alcançando até classe 1, nas melhores amostras (Est. IX-A e C), segundo a classificação de Walter (1972). A qualidade de visualização cai na medida que as lâminas escuras vão se tornando mais claras e homogêneas. Foram tomadas 106 medidas de lâminas escuras (L2) e 107 de lâminas claras (L1) em duas lâminas petrográficas da amostra LAV-32 (Est. IX-A e C). Os valores obtidos estão entre 0,01 a 0,38 mm, tanto para L2 quanto para L1, com maior concentração para L2 entre 0,04 e 0,18 mm e para L1 entre 0,04 a 0,26, como ilustrado na Figura 25. As lâminas escuras e claras tem um pico principal menor que 0,1 mm, sendo que as claras alcançam maiores espessuras.

Fairchild (1977) também apresenta valores de espessuras de laminação para as mesmas lâminas analisadas, obtidos a partir de 170 medidas de L2 e 165 de L1. Os valores variam de L2 entre 0,01 e 0,2 e de L1 entre 0,01 e 0,46, com uma maior concentração para L2 entre 0,01 e 0,1 mm e para L1 entre 0,01 a 0,26, como ilustrado no gráfico abaixo (Figura 26). Nota-se por estes gráficos que as lâminas escuras e claras tem um pico principal menor que 0,1 mm, sendo que as claras alcançam maiores espessuras. 


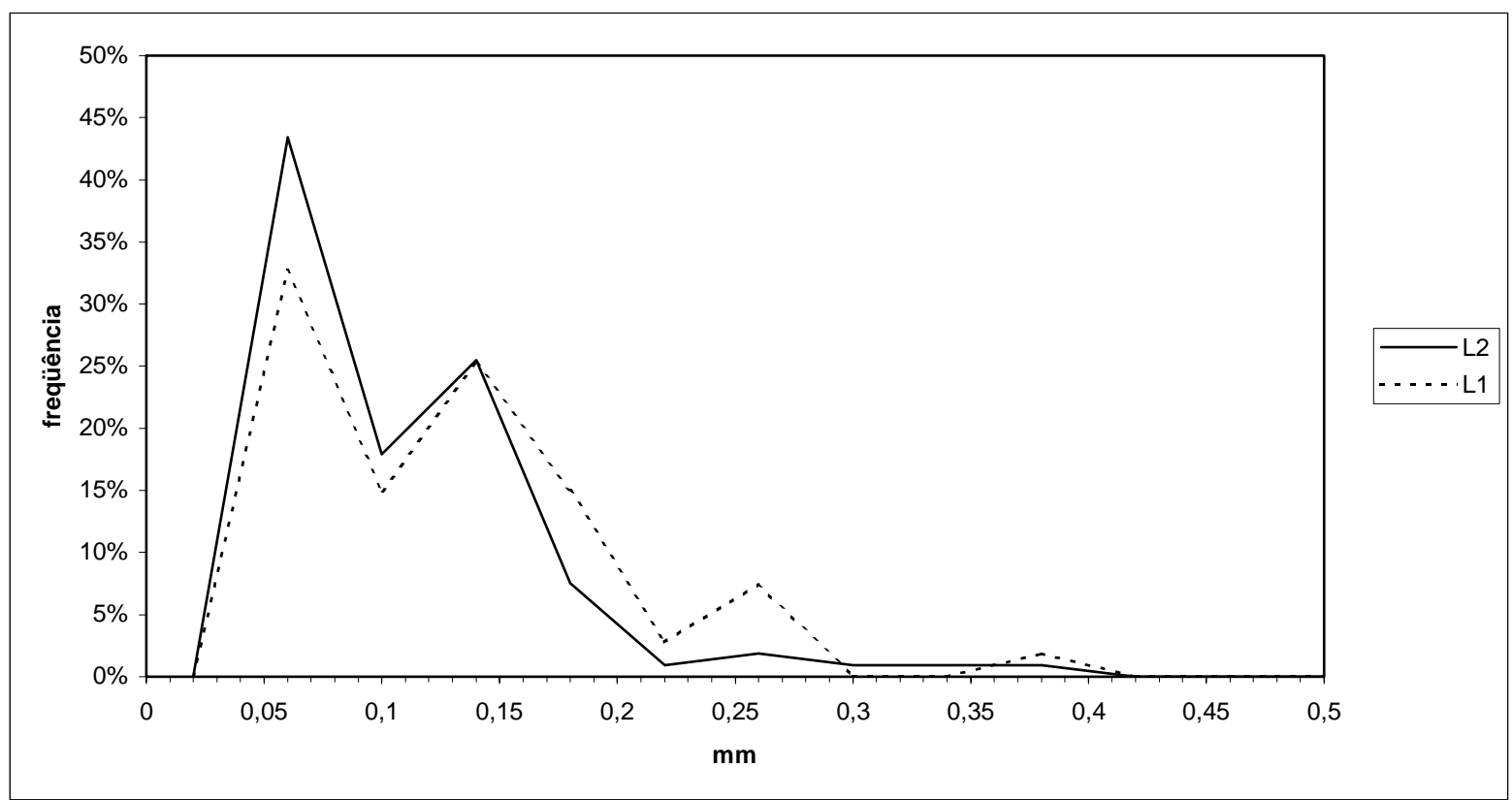

Figura 25: Freqüência relativa das lâminas escuras (L2) e claras (L1) da amostra LAV-32. N=106 (L2) e 107 (L1).

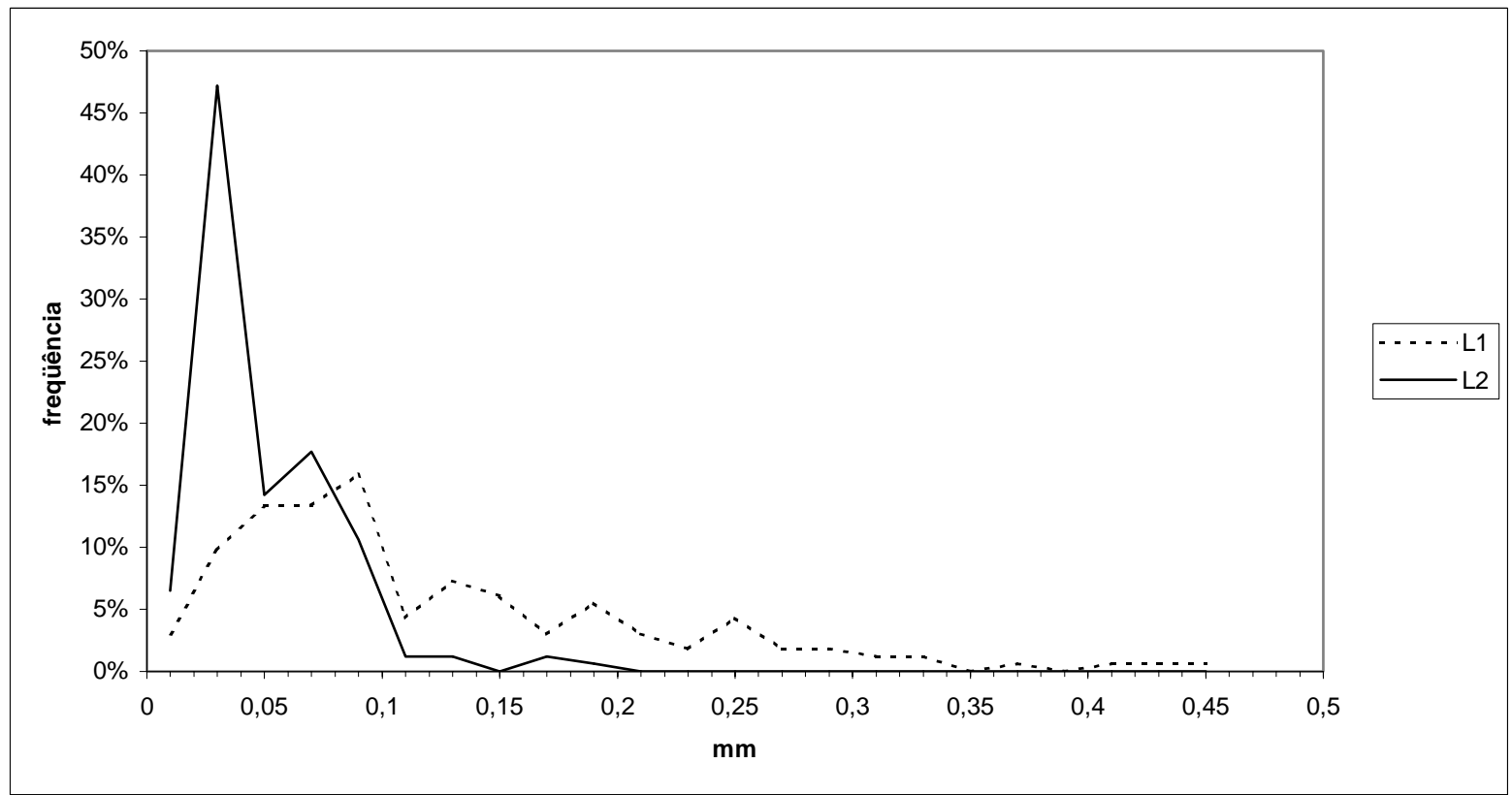

Figura 26: Gráfico de Fairchild (1977) da freqüência relativa das lâminas escuras (L2) e claras (L1) da amostra LAV-32. N=170 (L2) e 165 (L1).

Já em lâminas petrográficas de IND, existem casos de preservação relativamente boa (classe 2) com a laminação clara e escura bem definida (Est. IX-D). Em algumas amostras muito deformadas, a laminação é mal preservada, com lâminas claras e escuras apagadas, restando apenas uma laminação reliquiar de coloração clara e 
homogênea (Est. IV-B). Ainda em lâmina petrográfica, verificou-se que as margens das colunas são bastante irregulares e tectonizadas (cisalhadas), com sedimento intercolunar foliado (Est. IX-B). Não foram tomadas medidas de espessura de laminação para as lâminas de IND, pois ela se encontra muito recristalizada, com cristais de calcita fortemente orientados.

Desenhos da laminação elaborados a partir de fotografias de lâminas mostram bem o aspecto da laminação fina e a distribuição das lâminas claras e escuras (Figura 27). Através destes desenhos observa-se que existe uma maior densidade de lâminas claras do que de escuras, devido a processos posteriores de dolomitização e/ou recristalização (Figura 27).

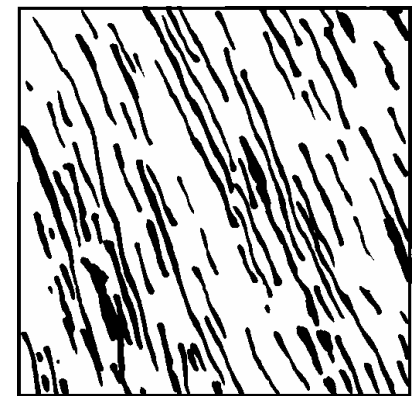

A

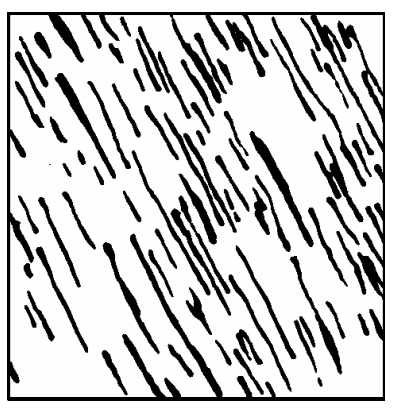

B

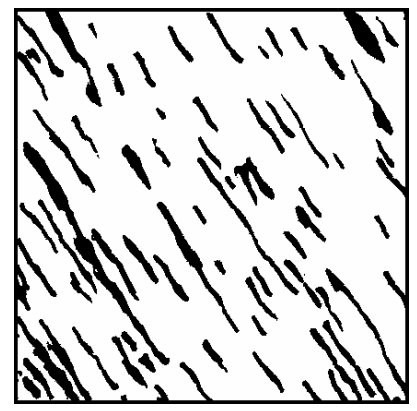

C

Figura 27: Desenhos da laminação elaborados a partir de fotografias de lâminas petrográficas. A área de cada desenho corresponde a $1 \mathrm{~cm}^{2}$. A - LAV - Est. IX-A; B - LAV - IX-C; C - IND - Est. IX-D.

\section{Morfogênese}

Donaldson \& Taylor (1972) foram os primeiros a reconhecer que o grupo Conophyton ocorria em águas relativamente profundas, baseados na ausência de estruturas sedimentares de águas rasas associadas (Figura 9). Hoffman (1976) estimou a profundidade de ocorrência de Conophyton, para a Formação Taltheilei (Paleoproterozóico do Canadá), entre 10 e 100 metros, ou mais. Em águas com menos de 10 metros de profundidade, segundo Hoffman (1976), Conophyton passaria para Jacutophyton, e com menos de 1 metro ocorreriam outras formas colunares não coniformes (Figura 28). 


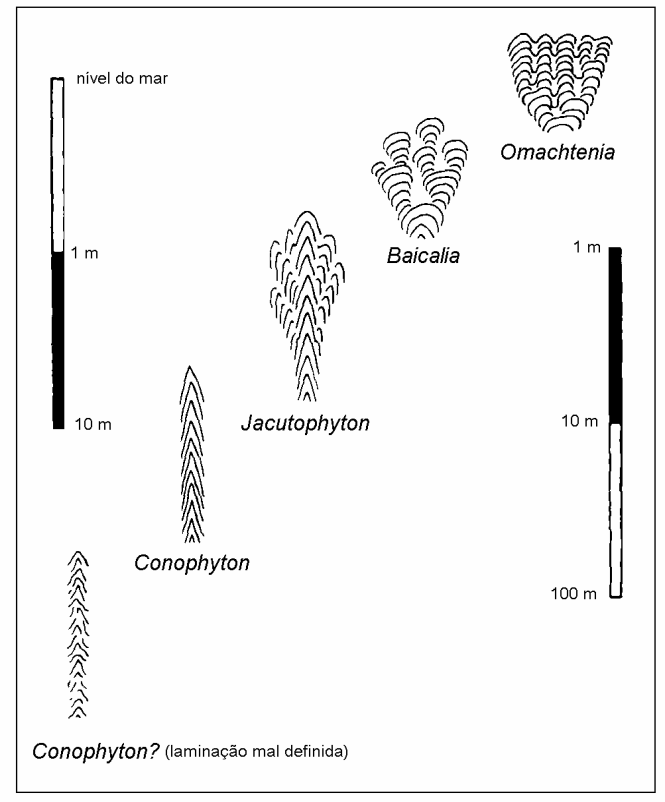

Figura 28: Relações pressupostas de alguns tipos de estromatólitos com a profundidade da água, para a Formação Taltheilei (Paleoproterozóico do Canadá) (Hoffman, 1976).

Os estromatólitos estudados estariam distribuídos sobre o assoalho marinho exibindo individualmente relevos de até $70 \mathrm{~cm}$ (Figura 29), mas quando se observa que eles formariam estruturas maiores compostas por conjuntos de estromatólitos individuais, este relevo pode ter sido muito maior.

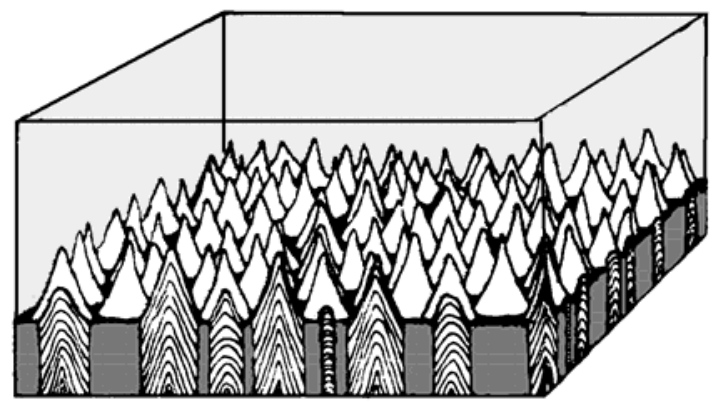

Figura 29: Modelo de um assoalho marinho com diversas colunas de estromatólitos cônicos, como deve ter ocorrido em LAV. Os estromatólitos podem ter alcançado até $70 \mathrm{~cm}$ de relevo (Walter, 1977).

A presença mais comum de formas maiores, compostas e agregadas associadas a formas não cônicas (forma 2) em LAV parecem indicar uma menor profundidade da água e consequentemente uma luminosidade alta. Especula-se que a origem das estruturas 
compostas por estromatólitos individuais seja reflexo desta alta luminosidade, onde um crescimento lateral seria favorecido, como visto na Figura 30 (C).

Já em IND as colunas são mais estreitas e espaçadas e a presença de argila na rocha (ver item 5.4.3), permitem inferir que as condições eram de baixa luminosidade, favorecendo um maior crescimento vertical (Figura $30 \mathrm{~A} \mathrm{e} \mathrm{B)}$.

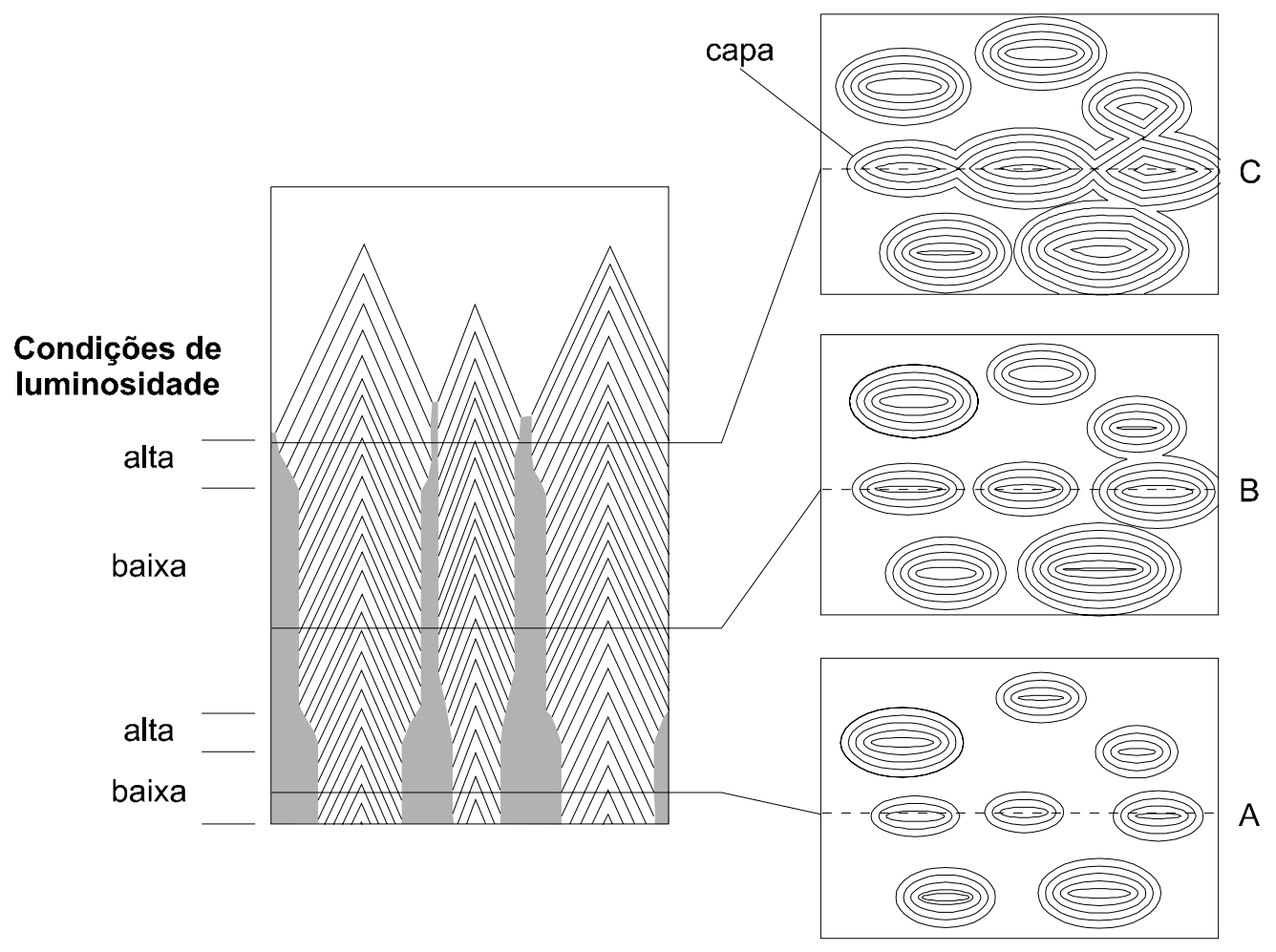

Figura 30: Esquema de crescimento para a Forma 1, adaptado de Donaldson (1976), e na premissa que o crescimento vertical é favorecido em luminosidade baixa e o crescimento lateral em luminosidade alta. De A para $C$ vemos um aumento da proximidade entre as colunas devido ao crescimento lateral. Há em $\mathrm{C}$ a formação de uma capa recobrindo diversas colunas agregadas. 
A, B - LAV - Fotografia (A) e desenho interpretativo (B) de um conjunto de diversas colunas próximas, em corte transversal, na parede da pedreira. Note no centro do desenho que algumas colunas são assimétricas. As linhas grossas correspondem ao espaço entre as colunas.

C - LAV - Detalhe de D, mostrando conjunto de colunas em corte transversal, na parede da pedreira. A escala corresponde a $15 \mathrm{~cm}$.

D, E - LAV - Fotografia (D) e desenho interpretativo (E), mostrando um conjunto de colunas grandes (com pelo menos $40 \mathrm{~cm}$ de eixo maior) assimétricas. No lado direito do desenho notam-se algumas colunas assimétricas. As linhas grossas correspondem ao espaço entre as colunas.

F, G - IND - Conjunto de diversas colunas próximas em corte transversal. Nota-se uma grande coluna (com pelo menos $50 \mathrm{~cm}$ de eixo maior), do lado esquerdo da fotografia, circundada por colunas menores, havendo coalescência. A escala corresponde a $5 \mathrm{~cm}$. G

- Desenho esquemático de F. As linhas grossas correspondem ao espaço entre as colunas. 
ESTAMPA VII - Forma 1 (Conophyton) de LAV

A - Grande coluna, em corte longitudinal, exibindo laminação cônica (fotografia tomada por T.R. Fairchild, em 1976). Escala corresponde a 15 cm. Amostra LAV-30.

B - Corte longitudinal, com laminação cônica evidente. Notar o padrão de manchas claras e escuras. Amostra LAV-01.

C - Preservação tridimensional de ápice de um cone. Amostra LAV-24.

D - Vista oblíqua de cortes longitudinal e transversal, mostrando, respectivamente laminação cônica com zona axial e contorno circular. Amostra LAV-21.

E - Bloco, em corte transversal, com várias colunas grandes agrupadas, próximas, com contornos elípticos (fotografia tomada por T.R. Fairchild, em 1976). A escala corresponde a $5 \mathrm{~cm}$.

F - Amostra em corte transversal de uma grande coluna com contorno elíptico. Amostra LAV-04. Escala corresponde a $5 \mathrm{~cm}$.

G - Coluna menor com contorno circular. Amostra LAV-21.

$\mathrm{H}$ - Colunas próximas exibindo contornos poligonais e desenvolvimento assimétrico (coluna mais completa) (fotografia de T.R. Fairchild, em 1976). 

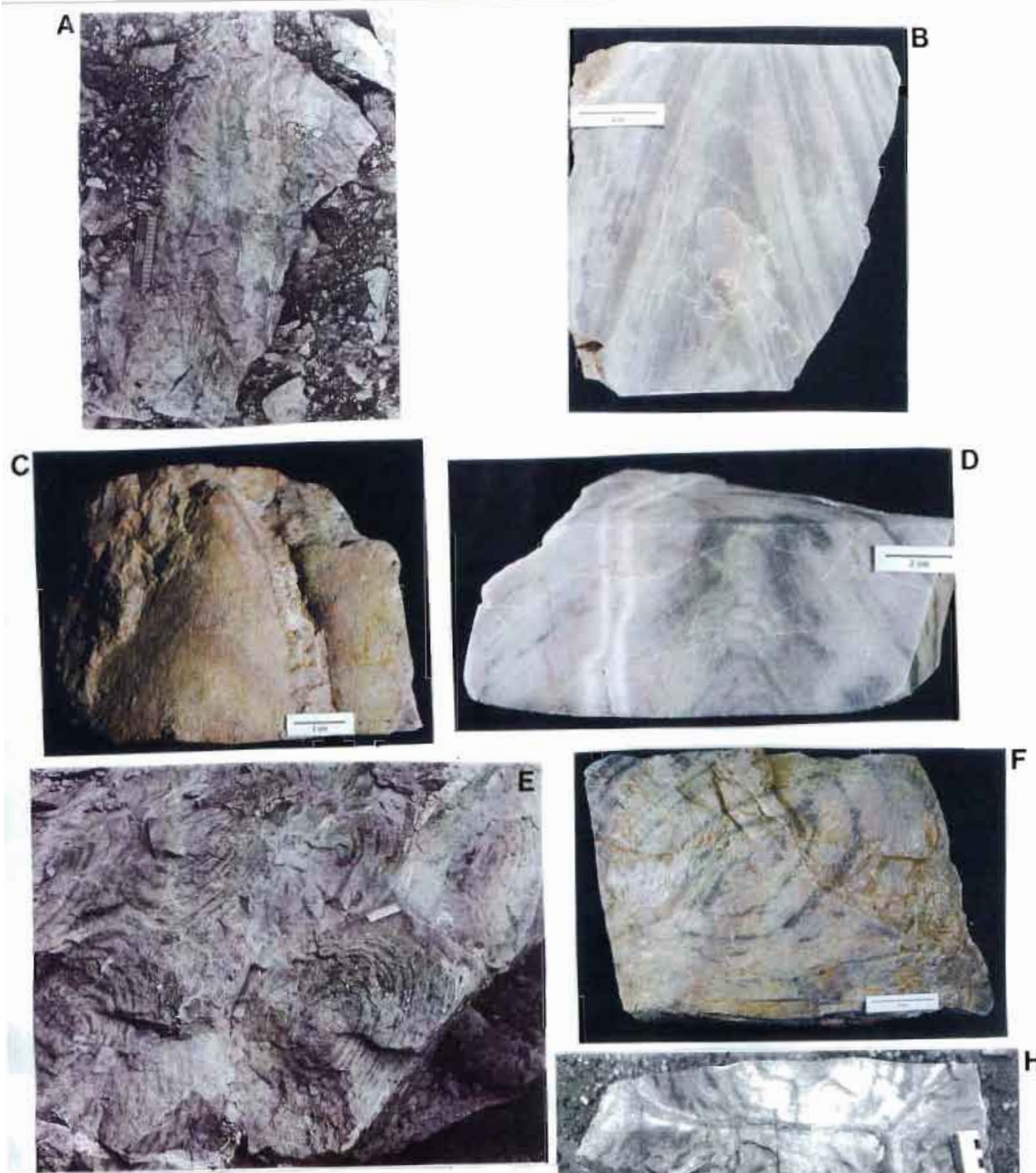

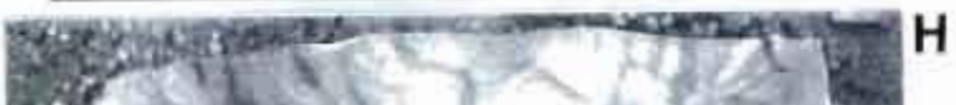
30
5 a G 1 (3)

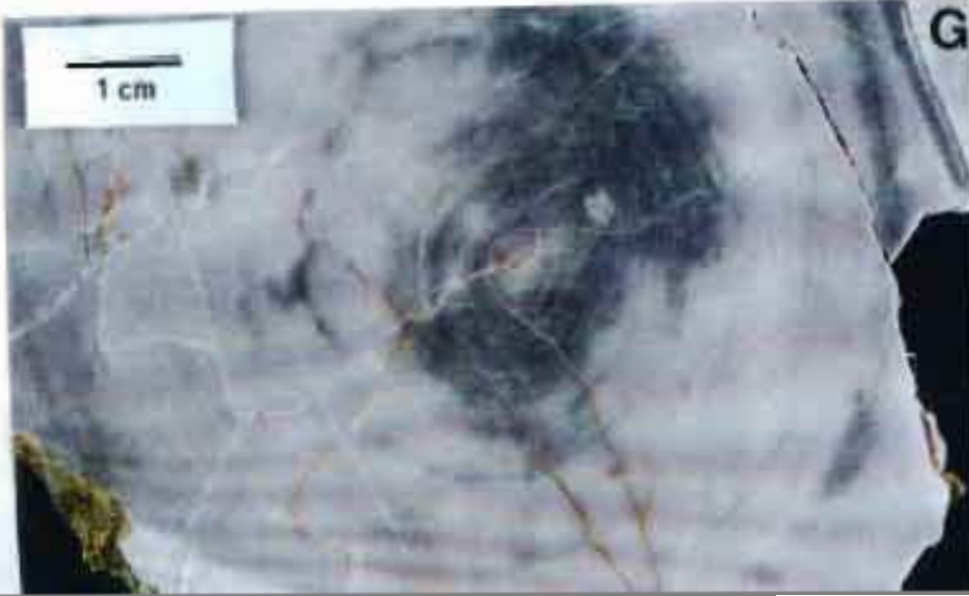

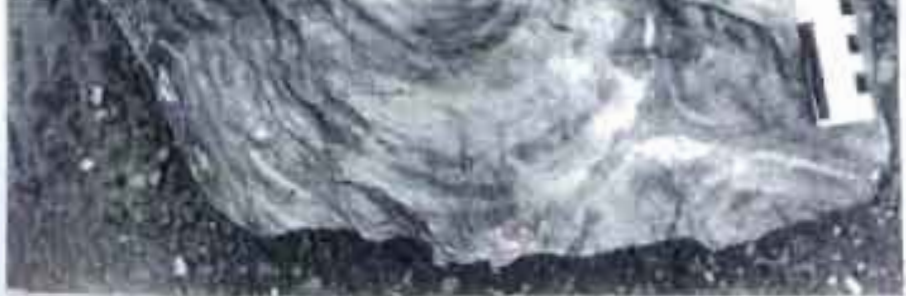


ESTAMPA VIII - Forma 1 (Conophyton) de IND e CHB

A - IND - Bloco intemperisado com colunas muito próximas, lateralmente comprimidas (fotografia tomada por T.R. Fairchild, em 1976). A escala corresponde a $15 \mathrm{~cm}$.

B, C - IND - Fotografia (B) e desenho interpretativo (C) de uma superfície intemperisada com diversas colunas agrupadas, deformadas.

D - IND - Grande coluna, em corte longitudinal, com cerca de $60 \mathrm{~cm}$ de largura, com laminação cônica. A escala corresponde a $15 \mathrm{~cm}$.

E - IND - Corte longitudinal de quatro colunas pequenas de estromatólitos cônicos. A zona axial é evidente na coluna indicada pela seta. Amostra IND-24.

$\mathrm{F}$ - CHB - Coluna em corte longitudinal com zona axial evidente. $O$ alto ângulo formado pela laminação cônica é devido ao achatamento pela deformação. Amostra CHB-03.

G - IND - Amostra intemperisada com diversas colunas agrupadas, de contornos elípticos, e laminação fina. Amostra IND-16.

H - IND - Corte transversal de uma coluna de contorno elíptico e laminação fina. Amostra IND-23. 


\section{B}
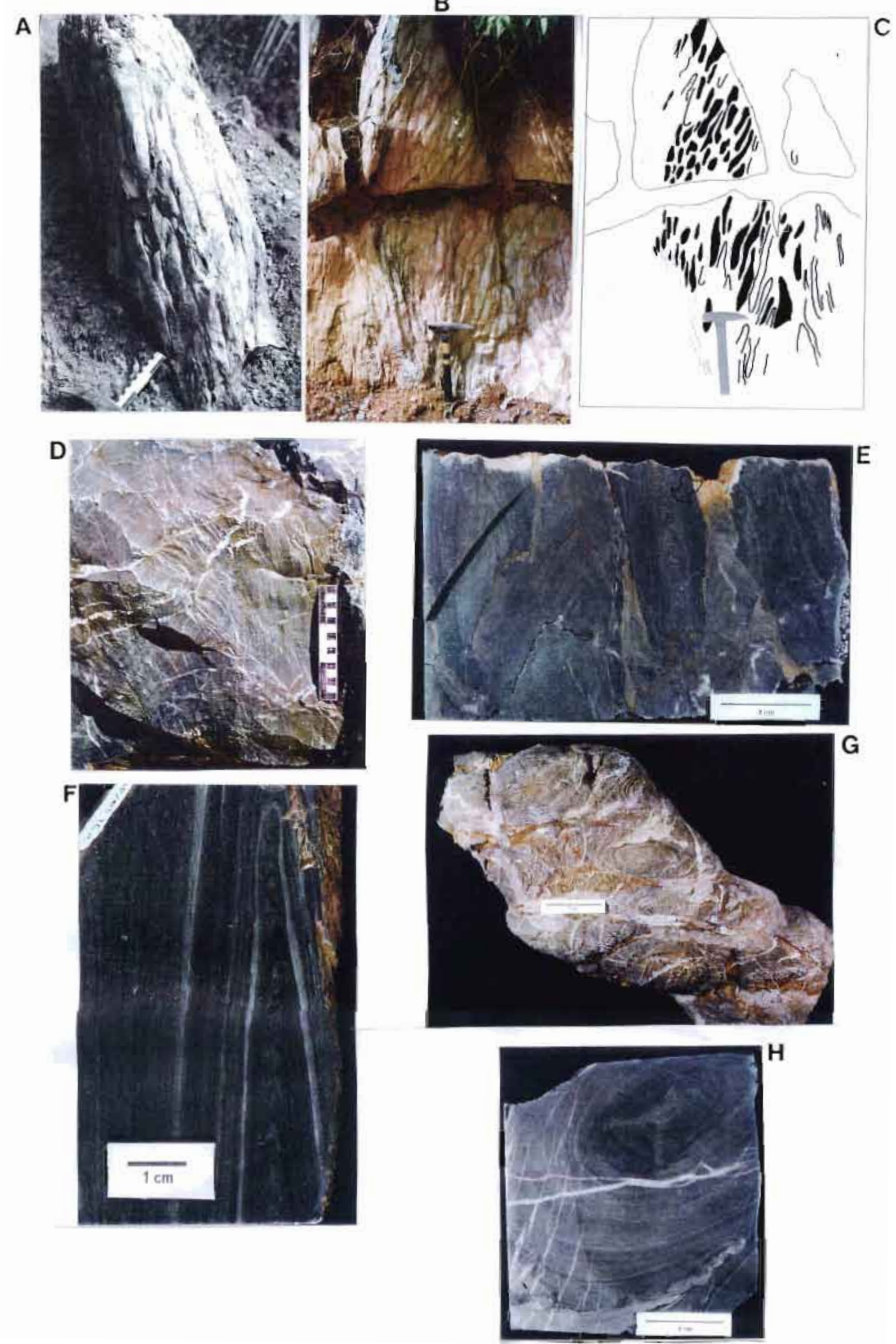
ESTAMPA IX - Microestrutura da Forma 1 (Conophyton)

A - LAV - Corte longitudinal de uma coluna, com detalhe da zona axial. A laminação é fina e bem definida, com as lâminas claras mais espessas que as escuras. Amostra LAV32.

B - IND - Corte longitudinal de uma coluna, com laminação fina mas mal definida e zona axial já bastante apagada devido à recristalização. Notar também as margens irregulares (tectônicas) e o sedimento intercolunar foliado. Amostra IND-24.

C - LAV - Corte longitudinal de uma coluna, com detalhe da laminação fina e bem definida, com as lâminas claras mais espessas que as escuras. Amostra LAV-32.

D - IND - Corte longitudinal de uma coluna, muito deformada, com laminação fina e bem definida e as lâminas claras mais espessas que as escuras. 

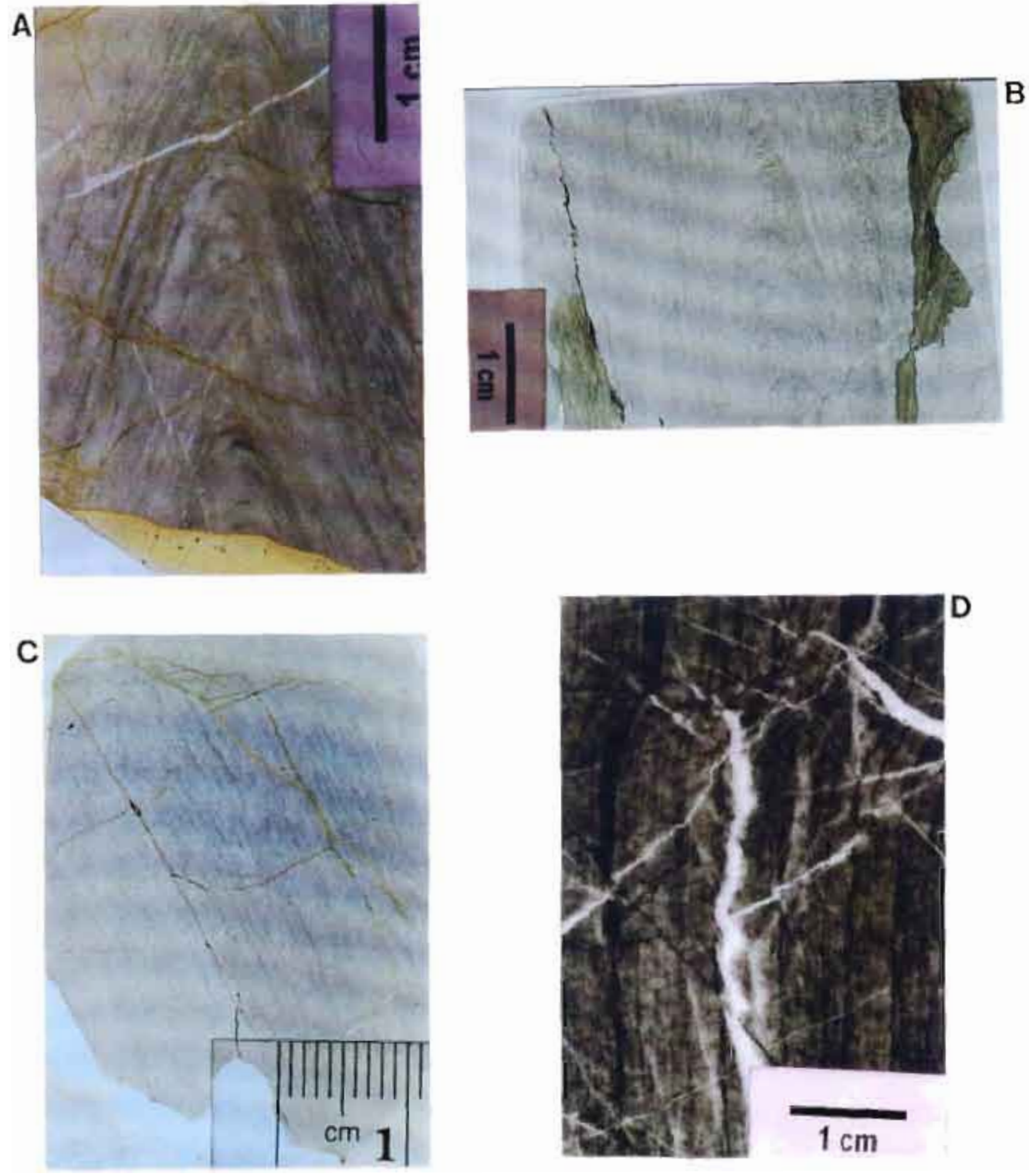


\section{Forma 2 - Estromatólitos colunares ramificados}

A Forma 2 é uma forma colunar ramificada, com laminação convexa e contornos transversais alongados. Exemplos bastante semelhantes entre si ocorrem em LAV, NCM, ITN, TGU e IB1, apesar da distância entre estas localidades. Esta forma foi observada apenas nos metacalcários dolomíticos. Em IB1 os estromatólitos apresentam silicificação parcial, com lâminas finas de sílica, concordantes com a laminação carbonática, sílica dispersa em meio ao carbonato, bem como sílica posterior em fraturas ou preenchendo vazios entre a laminação estromatolítica.

Em LAV a preservação é de classe 2 para as colunas e de 1 a 2 para a laminação. Já em IB1 a qualidade chega até a classe 1, tanto para as colunas como para a laminação.

Algumas descrições feitas por Almeida em 1944 (p. 96-100, Estampas I a IV) se assemelham a estromatólitos da Forma 2, pois em corte longitudinal aparecem como formas colunares paralelas a ligeiramente oblíquas, com laminação convexa e espaços intercolunares de 3 a 10 milímetros de largura, e, em cortes transversais, contornos circulares, elípticos a poligonais, com laminação concêntrica, tangencial nas margens.

Os tipos de "Collenia itapevensis" ilustradas na Est. II, parecem pertencer a esta forma.

As tabelas 8 e 9 quantificam o material utilizado em laboratório para caracterizar a Forma 2.

\begin{tabular}{|c|l|c|}
\hline Localidade & Número das amostras & Total de amostras \\
\hline LAV & $03,06,11,12,15,18,19,28,29$ & 9 \\
\hline NCM & 32 & 1 \\
\hline IB1 & 07 & 1 \\
\hline
\end{tabular}

Tabela 8: Amostras utilizadas para caracterização da Forma 2.

\begin{tabular}{|l|c|c|c|c|}
\hline Localidade & $\begin{array}{c}\mathrm{n}^{\circ} \text { de amostras } \\
\text { analisadas na } \\
\text { morfometria }\end{array}$ & $\mathrm{n}^{\circ}$ de faces & $\mathrm{n}^{\circ}$ de colunas & $\begin{array}{c}\text { Total de medidas } \\
\text { para morfometria }\end{array}$ \\
\hline LAV & 8 & 101 & 62 & 247 \\
\hline NCM & 1 & 4 & 3 & 14 \\
\hline ITN & 0 & 0 & 0 & 0 \\
\hline TGU & 0 & 0 & 0 & 19 \\
\hline IB1 & 1 & 10 & 5 & \multicolumn{2}{|c|}{} \\
\hline
\end{tabular}

Tabela 9: Dados utilizados para morfometria na Forma 2. 


\section{Arranjo das colunas:}

As colunas estão orientadas paralelamente, com atitude normal (G.1) (Est. X-A a D), e estão próximas (H.2) (Est. X-A a I) (Figura 31 e 32), separadas por apenas 1 a 3 mm, como medido em amostras e lâminas petrográficas. A razão área total (AT) vs. área das colunas (AC) medida em corte transversal em quatro amostras (Figura 32) gira em torno de 0,9 , o que indica uma alta densidade de colunas.

\section{Forma das colunas:}

As colunas têm forma cilíndrica simples (C.5) (Figura 31 A, E, F, G e H; Est. X-A, D e E) a cilíndrica ramificada (D.5) em corte longitudinal (Figura 31 A, B e D; Est. X- B e C), e tem margens lisas (M.1). Tem até $35 \mathrm{~cm}$ de altura (parcial) observada. A freqüência de ramificação é de em média 0,2, ou seja, quando ocorrem ramificações elas são pouco freqüentes (L.3) (Est. X-B e C). As ramificações são paralelas, do tipo $\alpha$ (I.1) e projeções em nicho (K.4) são comuns (Figura 31 B, C e D; Est. X-B e C).

Em planta são geralmente elípticas, oblongas (F.3) (Figura 32; Est. X-G e H) a equidimensionais poligonais (F.2) (Est. X-F). As formas elípticas possuem de 5 a $14 \mathrm{~cm}$ (parcial) no eixo maior e de 2 a $12 \mathrm{~cm}$ (parcial) no eixo menor em LAV e de 5 a $8 \mathrm{~cm}$ (parcial) no eixo maior e de 2 a $6 \mathrm{~cm}$ (parcial) no eixo menor em NCM. Os contornos alongados são, grosso modo, paralelos entre si. As colunas são por vezes coalescidas (F.7). Constituem formas pequenas no eixo menor e grandes no eixo maior, sendo relativamente altas, compridas e estreitas, muito próximas umas das outras (Figura 33) (Est. X-I). 


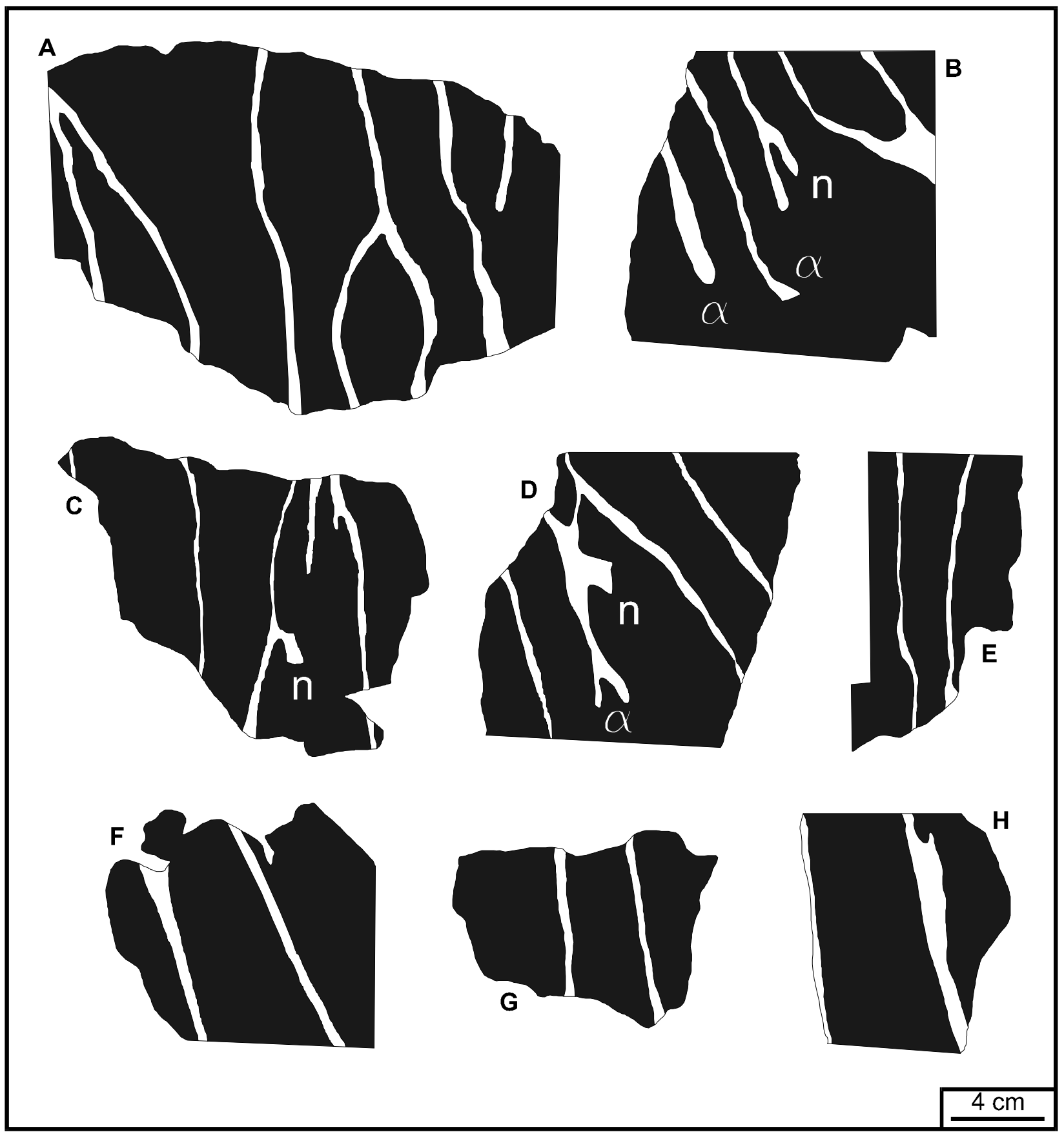

Figura 31: Silhuetas de colunas da Forma 2 em cortes longitudinais. A escala é igual para todas as figuras. $\alpha$ = ponto de ramificação e $n=$ projeção em nicho. A- LAV-15; B- LAV-12 (Est. X-B); C- LAV-29; D- LAV-12; E- LAV-11 (Est. X-A); F- LAV-11; G- NCM-32 (Est. X-D); H-IB1-07 (Est. XE). 


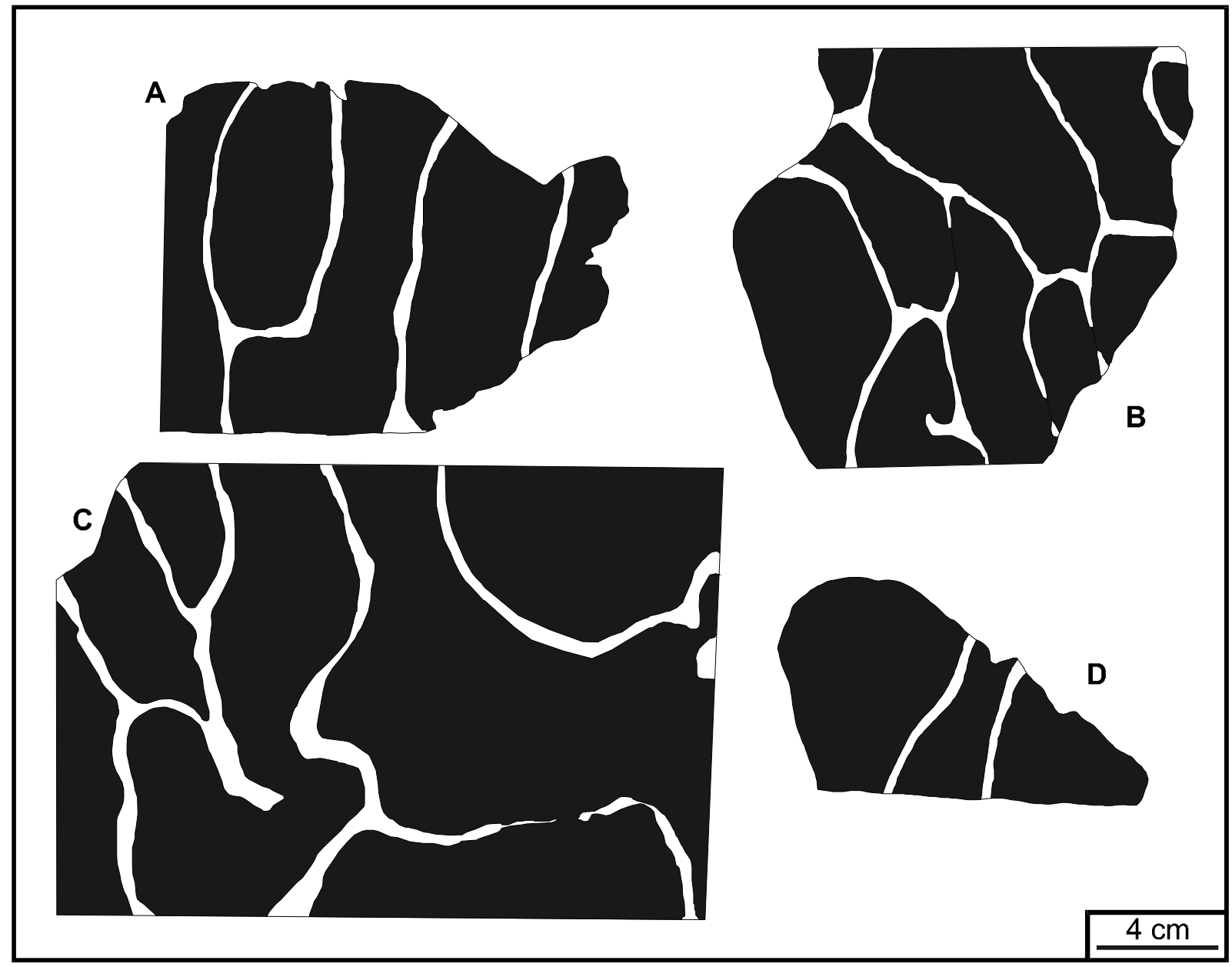

Figura 32: Silhuetas de colunas da Forma 2 em cortes transversais. A escala é igual para todas as figuras. A- LAV-11 (Est. X-F); B- LAV-29; C- LAV-15; D- NCM-32.

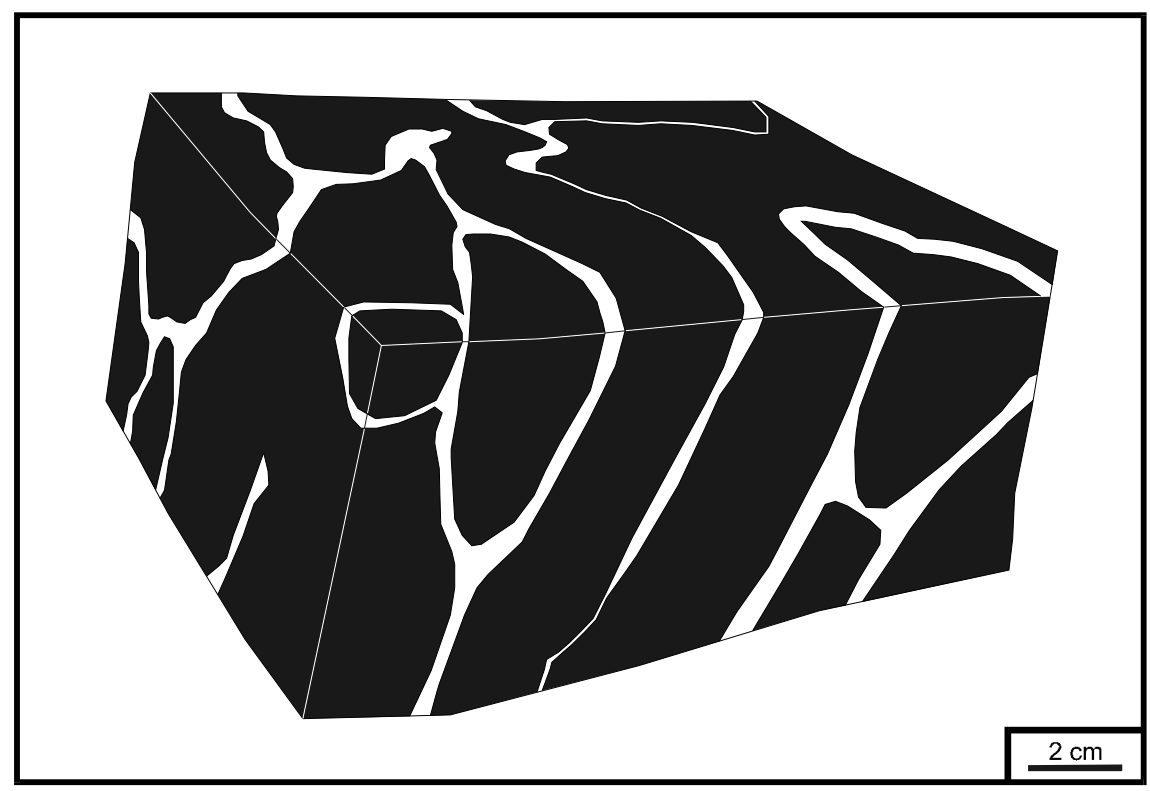

Figura 33: Silhuetas de colunas da Forma 2 vistas em cortes transversais e longitudinais ortogonais, na amostra LAV-15 (Est. X-I). 


\section{Forma das lâminas:}

O perfil laminar é bastante variável, principalmente em função da posição do corte analisado. De modo geral varia de pouco (N.3) (Figura 34 F; Est. X-D) a muito convexo (N.5) (Figura 34 G), até parabólico (Figura 34 D, E e F; Est. X-A), em cortes longitudinais no eixo menor. Em cortes longitudinais paralelos ao eixo maior é planar (N.2) a moderadamente convexo (N.4). O relevo sinótico é relativamente alto, variando de 1 a 6 $\mathrm{cm}$.

Possui grau de herança laminar alto e simétrico (Q.3) (Figura 34 A, E e G; Est. X-A e E) a alto e assimétrico (Q.4) (Figura 34 D e F; Est. X-D), perfil laminar muito convexo a parabólico (N.6).

A estrutura laminar marginal é infletida, geralmente com superposição extensa (S.4) (Figura 34 E; Est. X-A), mas ocorrendo também formas sem superposição (S.2) e com superposição parcial (S.3). Apesar do pouco espaço entre as colunas, não apresentam pontes.

\section{Microestrutura:}

Observa-se uma laminação fina, que possui alternância de camadas cinza escuras e cinza claras alternadas (Est. X-A), sem ritmicidade evidente. Ocasionalmente, ao atingir as margens, a laminação torna-se mais escura (Est. X-D), tal como o sedimento entre as colunas (Est. X-B). Apresenta, como a Forma 1, porções mais escuras onde a laminação está melhor preservada, em meio a mais claras.

A espessura da laminação, medida em uma lâmina petrográfica da amostra LAV11, revelou lâminas escuras entre 0,05 e 0,25 mm de espessura e lâminas claras entre 0,1 e $0,55 \mathrm{~mm}$. 


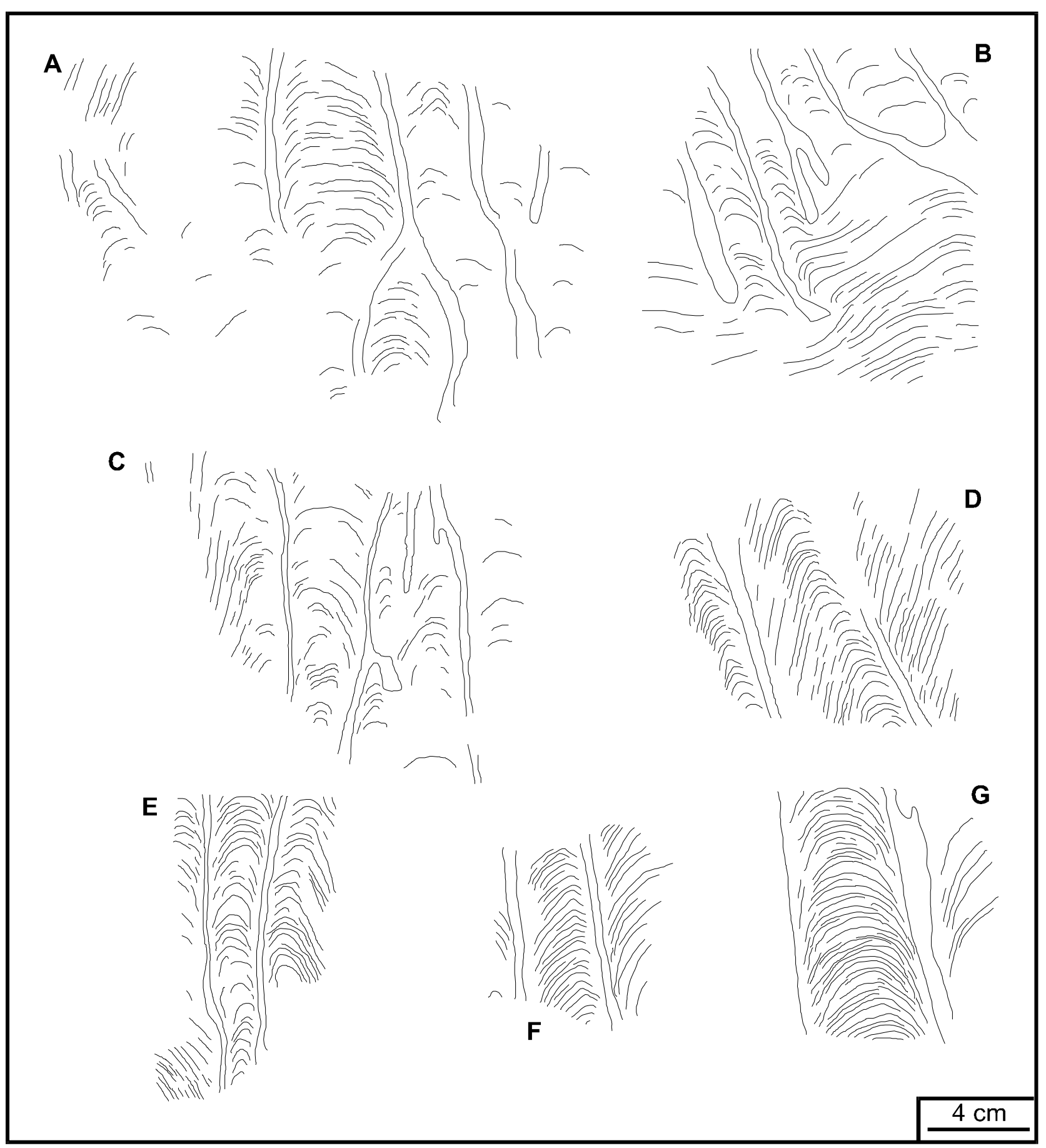

Figura 34: Laminação em corte longitudinal em amostras da Forma 2 de LAV, NCM e IB1. ALAV-15 (Figura 31 A); B- LAV-12 (Figura 31 B; Est. X-B e C); C- LAV-29 (Figura 31 C); D- LAV-11 (Figura 31 F); E- LAV-11 (Figura 31 E; Est. X-A); F- NCM-32 (Figura 31 G; Est. X-D); G- IB1-07 (Figura $31 \mathrm{H}$; Est. X-E). 
ESTAMPA X - Forma 2

A - LAV - Corte longitudinal de colunas próximas com laminação fina, muito convexa a parabólica. Alternância de lâminas claras e escuras, com margens das colunas mais escuras. Amostra LAV-11.

B, C - LAV - Fotografia (B) e desenho interpretativo (C) de várias colunas em corte longitudinal. Algumas apresentam ramificações e projeções, indicadas em $C$ pelas letras $\mathrm{R}$ e $\mathrm{P}$, respectivamente. Na porção inferior e a direita da amostra observa-se parte de uma coluna da Forma 3, abaixo das colunas da Forma 2. Amostra LAV-12.

D - NCM - Corte longitudinal de colunas de laminação assimétrica. Amostra NCM-32.

E - IB1 - Corte longitudinal de colunas, parcialmente silicificadas, com laminação convexa a muito convexa. Amostra IB1-07.

$F, G, H-L A V$ - Cortes transversais de colunas elípticas a poligonais. $F$ - Amostra LAV11; G - Amostra LAV-15; H - Amostra LAV-12.

I - LAV - Vista oblíqua de bloco cortado em três lados onde se observa os planos longitudinais e transversais. A escala corresponde a $4 \mathrm{~cm}$. Ver desenho desta amostra na Figura 33. Amostra LAV-15. 


\section{Forma 3 - Estromatólitos colunares não ramificados}

A Forma 3 é caracterizada por uma forma colunar não ramificada com laminação parabólica e contornos elípticos. Esta forma foi observada principalmente em IB1, ocorrendo também nas localidades de LAV e IND. Em NCM e TGU foram observadas em campo exemplares que podem ser atribuídos a esta forma, mas não foi possível fazer uma caracterização mais detalhada, devido a má preservação. Difere da Forma 2, pela ausência de ramificação, laminação mais convexa, contorno em planta elíptico, e não alongado, e tamanho maior.

Como observado na forma 2 em IB1 os estromatólitos apresentam silicificação parcial.

As tabelas 10 e 11 quantificam o material disponível em laboratório para caracterização da Forma 3.

\begin{tabular}{|c|l|c|}
\hline Localidade & \multicolumn{1}{|c|}{ Número das amostras } & Total de amostras \\
\hline IB1 & 01,02 & 2 \\
\hline IND & 14,31 & 2 \\
\hline LAV & 18 & 1 \\
\hline
\end{tabular}

Tabela 10: Amostras utilizadas para caracterização da Forma 3.

\begin{tabular}{|l|c|c|c|c|}
\hline Localidade & $\begin{array}{c}\mathrm{n}^{\circ} \text { de amostras } \\
\text { analisadas na } \\
\text { morfometria }\end{array}$ & $\mathrm{n}^{\mathbf{0}}$ de faces & $\mathrm{n}^{\mathbf{0}}$ de colunas & $\begin{array}{c}\text { Total de medidas } \\
\text { para morfometria }\end{array}$ \\
\hline IB1 & 2 & 10 & 5 & 29 \\
\hline LAV & 1 & 16 & 1 & 18 \\
\hline îND & 1 & 6 & 1 & 7 \\
\hline
\end{tabular}

Tabela 11: Dados utilizados para morfometria na Forma 3.

\section{Arranjo das colunas:}

As colunas estão orientadas paralelamente, com atitude normal (G.1) (Est. XI-A e C), e estão próximas (H.2) (Est. XI-A, C e E). O espaço intercolunar varia de 1 a 3 cm.

\section{Forma das colunas:}

São colunas cilíndricas retas (C.5), não ramificadas, com margens lisas (M.1) (Est. $\mathrm{XI}-\mathrm{A}, \mathrm{B}, \mathrm{C}$ e E), e de até um metro de altura, observada em campo (Est. XI-A). Os contornos em planta são arredondados (F.1) a elípticos (F.3) (Est. XI-G e H), de 10 a 20 $\mathrm{cm}$ no eixo maior e de 5 a $15 \mathrm{~cm}$ no eixo menor. 


\section{Forma das lâminas:}

As lâminas são mais comumente parabólicas (N.6), ocorrendo também moderadamente (N.4) a muito convexas (N.5) (Figura 35 A, B e C; Est. XI-B a E). Em cortes tangenciais a laminação é pouco convexa (Figura 35 D; Est. XI-F). A laminação forma um ângulo de aproximadamente $100-110^{\circ}$ em IB1. Em IND este ângulo é menor, cerca de $85^{\circ}$, que pode refletir a forte deformação neste local.

Tem grau de herança laminar alto e simétrico (Q.3) a assimétrico (Q.4) e estrutura laminar marginal infletida sem superposição (S.2) (Figura 35; Est. XI-B a E). O relevo sinótico varia entre 2 e $10 \mathrm{~cm}$.

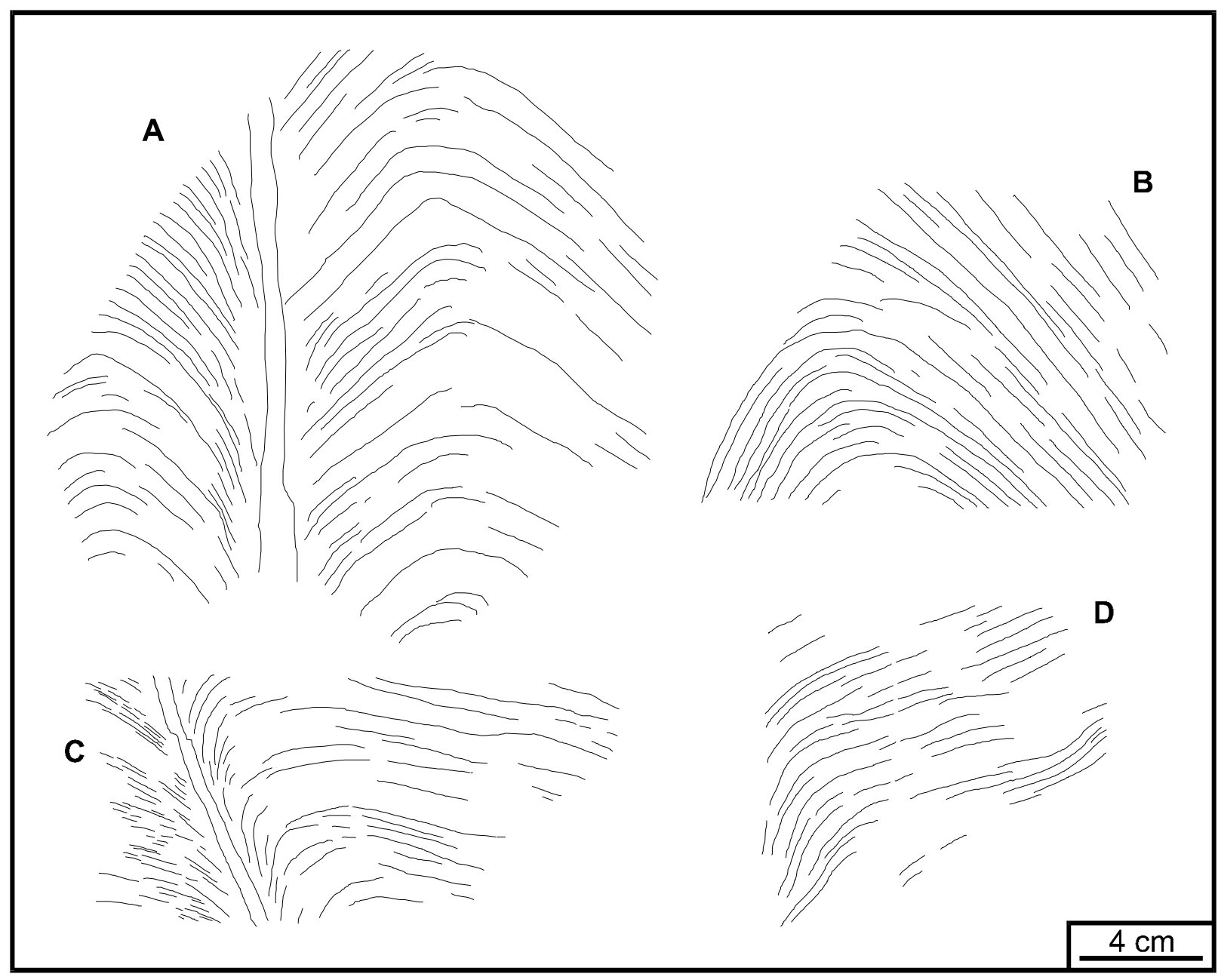

Figura 35: Laminação em corte longitudinal de amostras da Forma 3 de IB1, IND e LAV. A escala é igual para todas as figuras. As linhas verticais demarcam os limites das margens das colunas em A e C. A- IB1-01 (Est. XI-B); B- IND-14 (Est. XI-D); C- LAV-18 (Est. XI-E); D- LAV-11. 
ESTAMPA XI - Forma 3

A - IB1 - Colunas paralelas, retas e próximas, em corte longitudinal, num plano de fratura no corte da pedreira abandonada.

B - IB1 - Coluna exibindo laminação parabólica e com silicificação. Amostra IB1-02.

C - IND - Colunas paralelas, retas e próximas, em face longitudinal intemperisada. Amostra IND-31.

D, G - IND - Coluna com laminação parabólica, em corte longitudinal (D) e com contorno elíptico em corte transversal (G). Amostra IND-14.

$\mathrm{E}, \mathrm{F}, \mathrm{H}$ - LAV - Coluna com laminação muito convexa em corte longitudinal (E, indicada com asterisco), laminação pouco convexa em corte tangencial (F) e contorno elíptico em corte transversal $(H)$. Do lado direito, nas fotografias $E$ e $H$, ocorre parte de uma coluna da Forma 2. Em F observa-se uma alternância de lâminas claras e escuras bem preservada. Amostra LAV-18. 

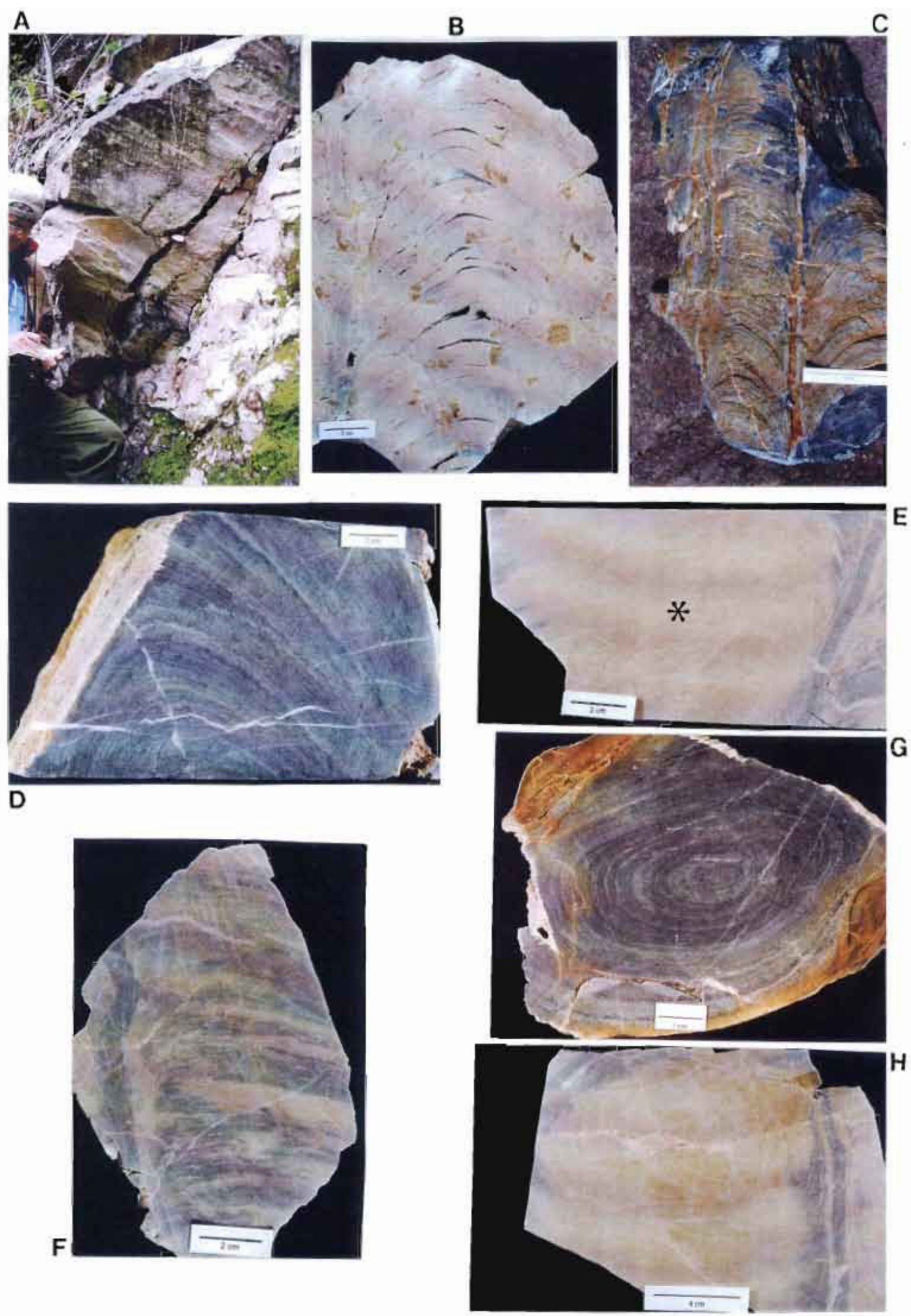


\section{Forma 4 - Estromatólitos colunares divergentes}

Esta forma foi observada principalmente em ITN, ocorrendo formas semelhantes em IB2 e TGU. A caracterização desta forma se deu com base apenas em fotografias de ITN, uma amostra de IB2 (IB2-01) e uma amostra de TGU (TGU-20), ilustradas na Est. XII (A a D). Não foi realizada análise morfométrica devido a escassez de amostras.

Há uma certa dúvida em relação a biogenicidade nas localidades IB2 e TGU, devido à escassez de exemplares, má preservação e sua semelhança com feições cársticas ou paleocársticas.

\section{Arranjo das colunas:}

As colunas são divergentes, com atitude normal (G.1) a inclinada (G.2), e estão próximas (H.2) (Est. XII-A a D). Em ITN as colunas se desenvolveram de modo divergente sobre calcários estratificados (Est. XII-A e B).

\section{Forma das colunas:}

São colunas cilíndricas (C.5), retas, com margens com costelas (M.4) ou fimbriadas (M.3) (Est. XII-A a D). As colunas possuem de 4 a $6 \mathrm{~cm}$ de largura e em ITN foram observadas formas com pelo menos $50 \mathrm{~cm}$ de altura.

\section{Forma das lâminas:}

As lâminas são moderadamente convexas (N.4), com grau de herança laminar moderado (Q.2) a alto e simétrico (Q.3), e estrutura laminar marginal infletida sem superposição (S.2) (Est. XII-A a D). 


\section{Forma 5 - Estromatólitos turbinados ramificados}

Esta forma é caracterizada pela forma turbinada ramificada. Foi encontrada por T. R. Fairchild, em 1976 no topo da seção em IND em local já destruído (Figura 20), e não foi observada durante o presente projeto. A caracterização desta forma se deu com base apenas em fotografias e antigos dados de campo. Esta forma ocorria de IND.

\section{Arranjo das colunas:}

As colunas são paralelas com atitude normal (G.1) agrupadas de forma próxima (H.2) (Est. XII-E e F).

\section{Forma das colunas:}

As colunas são turbinadas (D.3) a cilíndricas ramificadas (D.5), com margens lisas (M.1) (Est. XII-E e F), alcançando, aparentemente, de 8 a $30 \mathrm{~cm}$ de largura e pelo menos $60 \mathrm{~cm}$ de altura. As ramificações são paralelas do tipo $\alpha$ (I.1) (Est. XII-E). Os contornos em planta não foram observados.

\section{Forma das lâminas:}

As lâminas são pouco (N.3) a muito convexas (N.5), com grau de curvatura 1 (O.1) e grau de herança laminar alto e simétrico (Q.3) a assimétrico (Q.4), com ou sem superposição laminar marginal (S.2 e 3) (Est. XII-E e F). 


\section{Forma 4}

A, B - ITN - Em A, colunas divergentes desenvolvida sobre metacalcário estratificado, com laminação estromatolítica ressaltada com giz. Em B, silhuetas das colunas com laminação do substrato demarcada. A tampa da câmera possui $5 \mathrm{~cm}$ de diâmetro.

C - TGU - Coluna em corte longitudinal com margens fimbriadas. Amostra TGU-20.

D - IB2 - Colunas divergentes em corte longitudinal com margem irregular. Amostra IB201.

\section{Forma 5}

E - IND - Colunas ramificadas em corte longitudinal. Fotografia tomada por T.R. Fairchild. A escala corresponde a $15 \mathrm{~cm}$.

F - IND - Colunas turbinadas com laminação pouco a moderadamente convexa. A escala corresponde a $15 \mathrm{~cm}$. Fotografia tomada por T.R. Fairchild. 

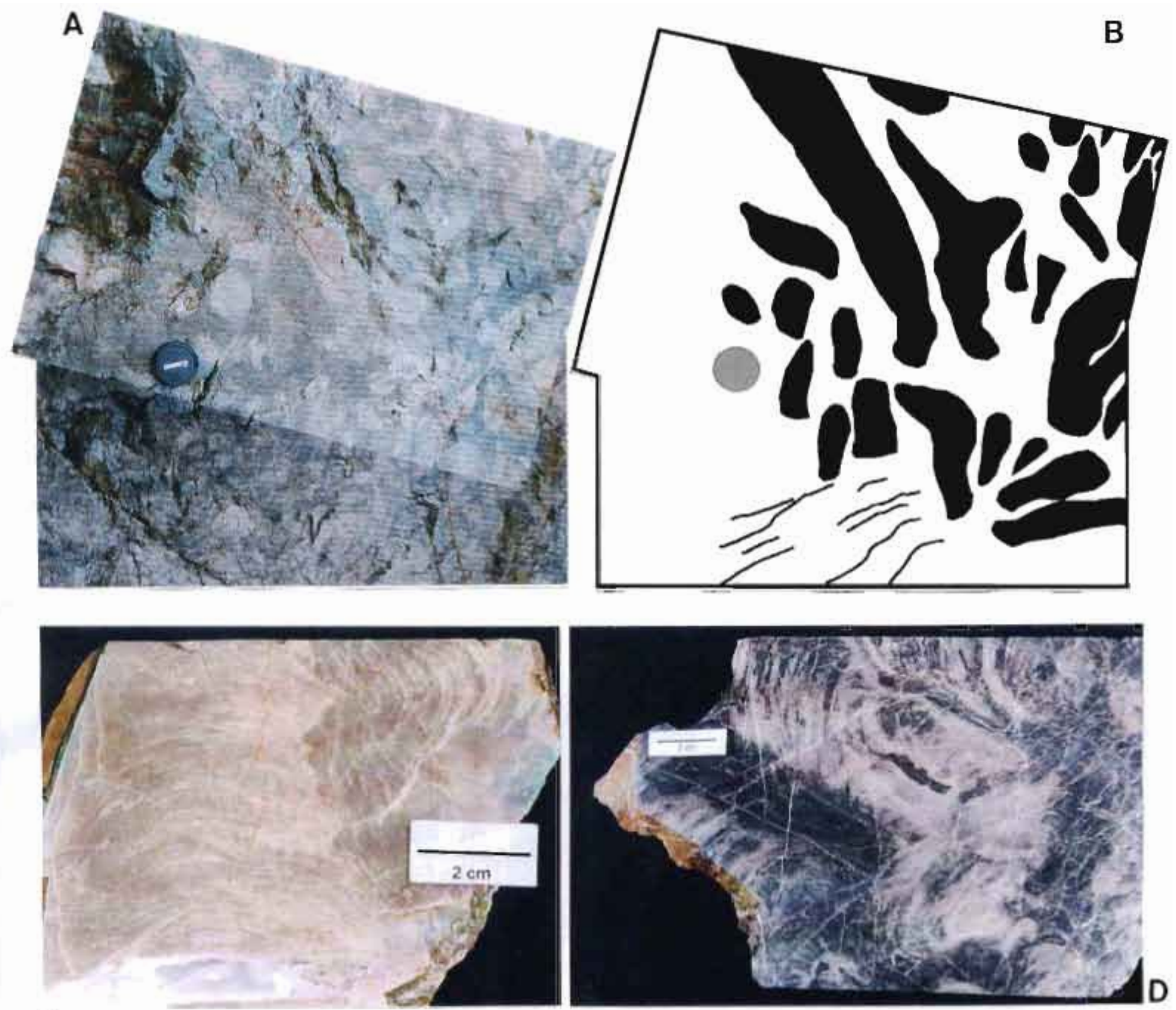

C

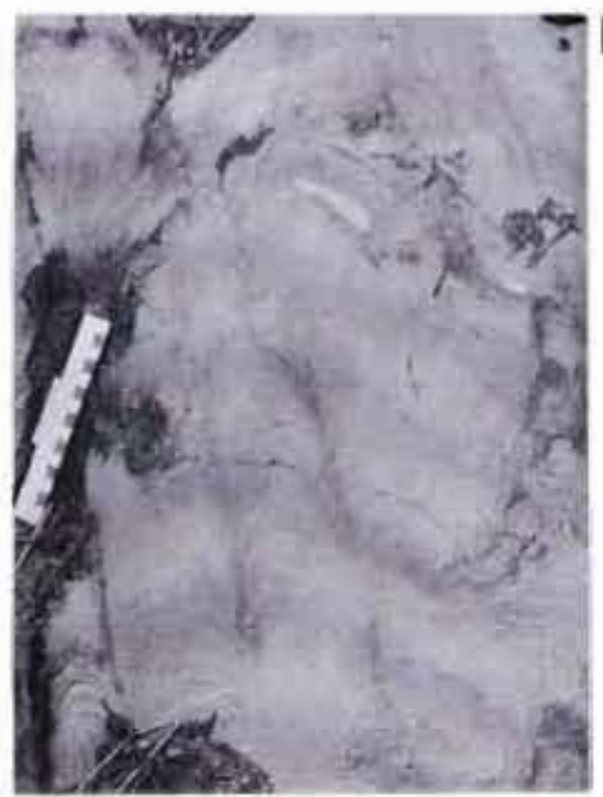




\subsubsection{Associações entre as formas}

As relações espaciais e genéticas entre as formas diferentes nas mesmas localidades são praticamente impossíveis de observar, dadas as complicações tectônicas nos metacalcários calcíticos e a deterioração laminação nos metacalcários dolomíticos. Por outro lado, apenas utilizando as amostras também é difícil definir como estas várias formas se relacionam em parte devido ao tamanho relativamente grande dos estromatólitos, especialmente da Forma 1.

Nos afloramentos observa-se que as formas cônicas coexistem com formas não cônicas (formas 2 e 3), sem ser possível precisar as relações entre elas. Em amostras observa-se que em alguns casos a Forma 2 ocorre ao lado da Forma 3 (Est. XI-E). Em algumas amostras nota-se que as colunas iniciam-se com a Forma 3, posteriormente passando para Forma 2 (Est. X-B e C).

As relações da Forma 4 com as outras não podem ser verificadas, pois é rara e ocorre de modo isolado. O mesmo acontece com a Forma 5, que só ocorre em IND, e só se pode dizer que ela ocorre no topo do bioerma acima dos estromatólitos cônicos (Est. XII-E e F).

\subsubsection{Aspectos composicionais}

Como visto acima, os estromatólitos estão presentes tanto em metacalcários dolomíticos quanto em calcíticos, com amplo predomínio na abundância dos dolomíticos, bem como das ocorrências de estromatólitos nestas rochas.

O metacalcário dolomítico de LAV se dissolve lentamente em $\mathrm{HCl}$ deixando um resíduo silicoso branco. Nota-se também que as colunas possuem menos resíduo que o material intercolunar (sedimento). Pelas figuras 36 e 37 verificou-se que as colunas são compostas por calcários dolomíticos puros.

O metacalcário calcítico de IND é facilmente solúvel, deixando um resíduo escuro de material argiloso e de matéria orgânica. A quantidade de resíduo nas colunas é muito menor do que no sedimento entre elas. Obteve-se um valor de 50\% de resíduo para o material (sedimento) entre estromatólitos cônicos (Figura 36) enquanto as colunas não passaram de 10\%. Pelas figuras 36 e 37 nota-se que as colunas são compostas essencialmente por calcário calcítico puro e o sedimento entre elas por material argiloso com carbonato. 
O metacalcário dolomítico de FSA é muito difícil de dissolver e o resíduo é bastante silicoso. As porções estromatolíticas (bandas avermelhadas) possuem menos impurezas que as bandas pretas e brancas entre as camadas estromatolíticas. Na Figura 37 obtevese um baixo teor de Ca e Mg e altos teores em K, com teor de Si alto especialmente nas camadas não estromatolíticas.

Os metacalcários dolomíticos, presentes em LAV, NCM, ITN, TGU e IB1, são de modo geral mais puros do que os metacalcários calcíticos, de IND e CHB. Em FSA as bandas avermelhadas eram mais puras e as pretas e brancas mais impuras. Em rocha total, maior quantidade de resíduo insolúvel ocorre em FSA, seguido de IND e de LAV. A Figura 36 demonstra estas variações quanto à quantidade de impurezas.

Os estromatólitos da localidade IB1 chamaram a atenção pois ocorriam estromatólitos da Forma 2, semelhantes aos de LAV, mas mais bem preservados quando silicificados e também menos deformados. A sílica substitui o carbonato, preenche vazios entre lâminas (ver item 6) e em fraturas cortando as colunas e o sedimento entre as colunas. Uma parte desta silicificação pode ser anterior a deformação, ocorrendo provavelmente na diagênese, e outra é posterior, principalmente deformacional, formando veios e preenchendo vazios, como fraturas e espaços entre as lâminas nos estromatólitos.

Um aspecto interessante dos metacalcários dolomíticos é sua deterioração, ou seja, perda de coloração (cinza) ao ser exposto à atmosfera. Isto pode ser constatado na pedreira abandonada de LAV onde os estromatólitos apresentam-se bastante apagados, muito mais do que quando observados primeiramente por T.R. Fairchild, em 1976 (T.R. Fairchild, com. verbal). Em uma amostra coletada nesta época (LAV-30; Est. VII-A) podiase observar a laminação claramente, mas atualmente não se vê quase nada. Uma explicação para isto é de que a coloração cinza é dada, pelo menos em parte, por matéria orgânica, que se oxida ao simples contato com o ar. 


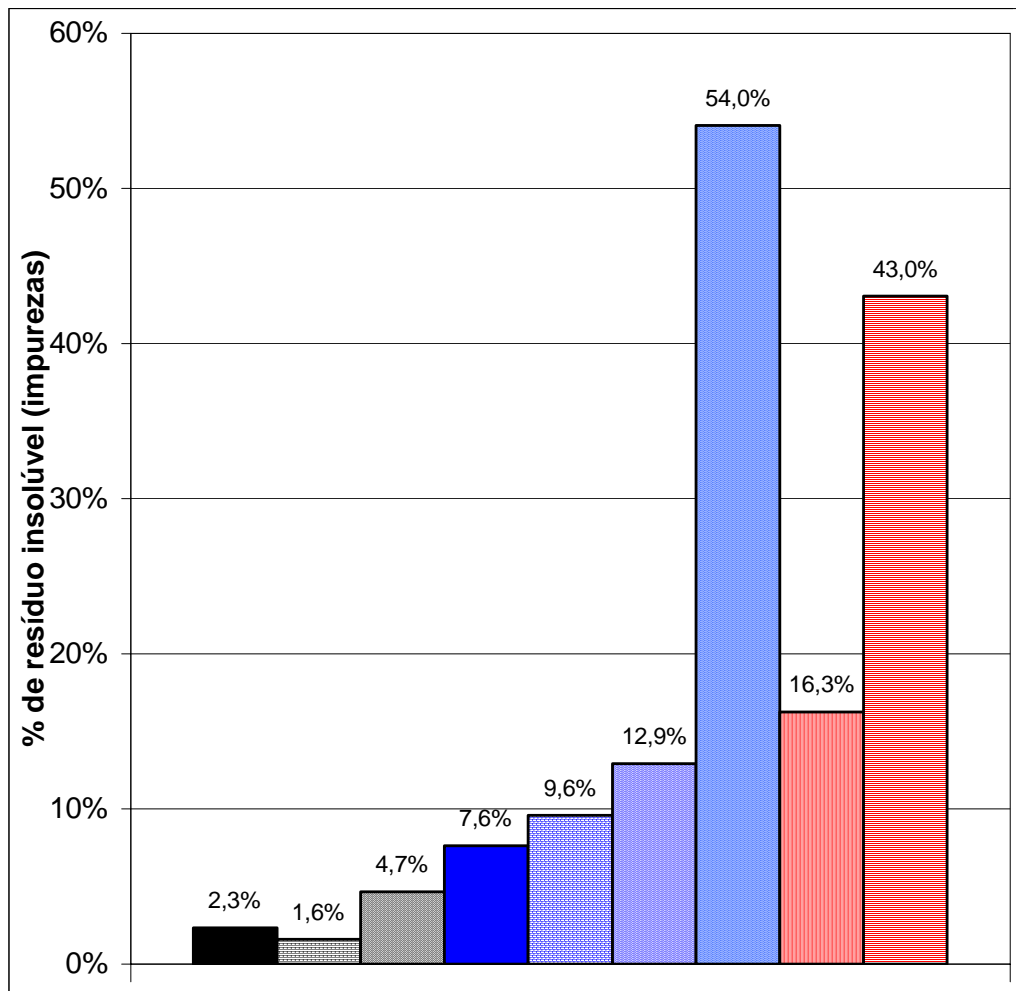

LAV (rocha total)

口LAV (coluna)

口LAV (sedimento intercolunas)

IND (rocha total)

口IND (coluna)

$\square$ IND (sedimento intercolunas)

$\square$ IND (sedimento intercolunas de estromatólitos cônico)

FSA (bandas avermelhadas)

目FSA (bandas preto e brancas)

Figura 36: Quantidade de impurezas obtidas por dissolução de amostras de LAV, IND e FSA.

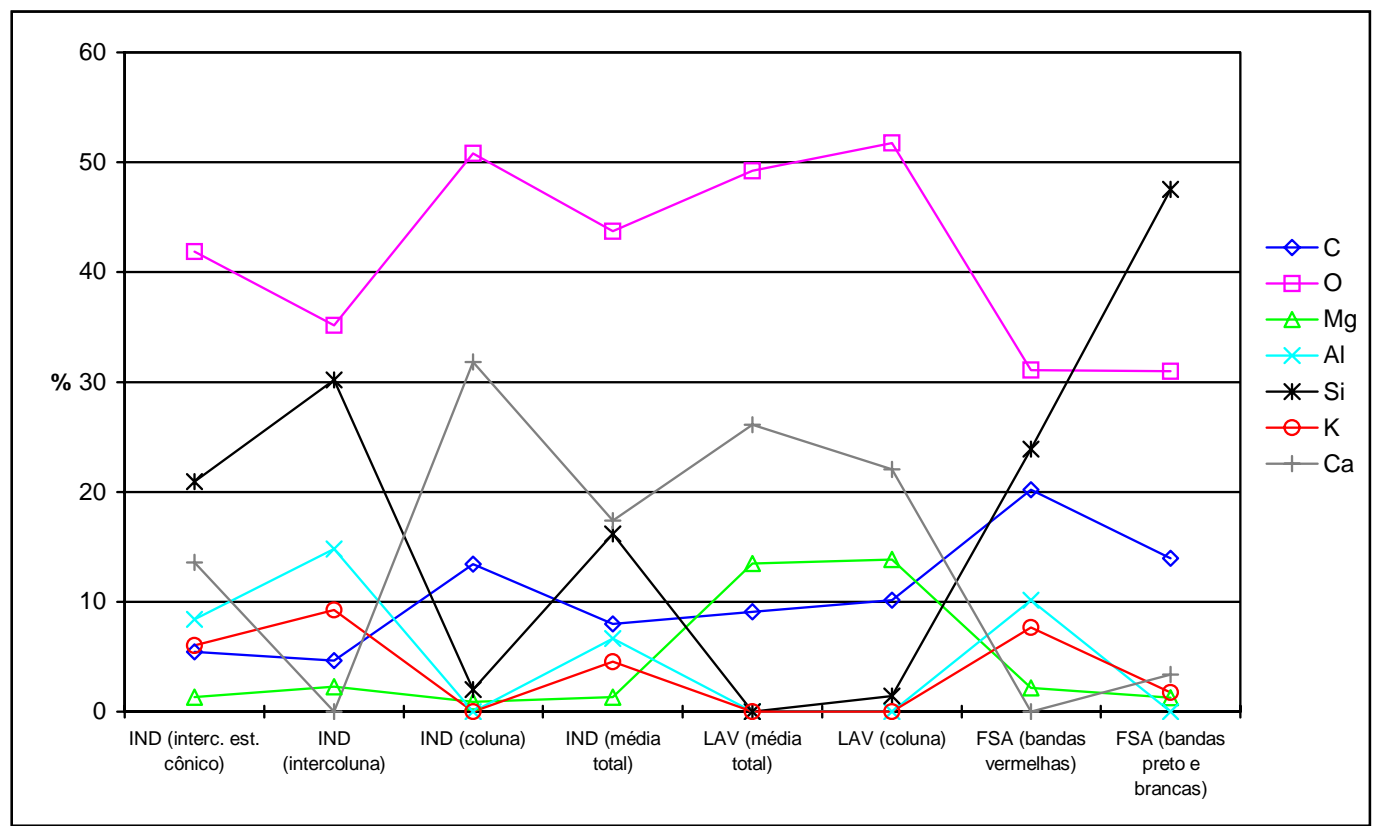

Figura 37: Elementos químicos maiores obtidos em análise química semi-quantitativa por EDS em amostras de LAV, IND e FSA. 


\section{ASPECTOS DEFORMACIONAIS}

O Grupo Itaiacoca é uma sucessão de metassedimentos de natureza carbonática, terrígena e vulcânica. Deste modo, a deformação deste pacote agiu de maneira diferenciada de acordo com as características e a competência de cada litologia. Os metacalcários do Grupo Itaiacoca, por exemplo, deformaram-se de maneira mais rígida e menos dúctil, ou seja, menos plasticamente, do que rochas menos competentes (p.ex., metapelitos). Assim, de modo geral, eles tenderam a formar grandes dobras abertas, estruturas rúpteis (fraturas, falhas, etc.) e a se recristalizar. Excepcionalmente ocorrem dobras apertadas, intensa recristalização ("marmorização") ou milonitização em zonas de deformação mais intensa, evidentemente zonas de falha.

Outras litologias, como metarenitos e metacherts exibem comportamento tectônico semelhante, enquanto as litologias menos competentes, tais como metapelitos e certas rochas vulcânicas, apresentam-se intensamente foliadas e dobradas.

A área de estudo foi severamente deformada, mas graças à competência tectônica dos calcários, muitos estromatólitos resistiram à deformação, embora não tenham escapado incólumes. As lentes e camadas de maior espessura (métrica) e maior concentração de estromatólitos (bioermas/biostromas) apresentam melhor preservação (p. ex., LAV e IND), apesar da perda de nitidez da laminação nos metacalcários dolomíticos (LAV) e a deformação dúctil mais intensa nos metacalcários calcíticos (IND). Estes corpos não costumam apresentar acamamento plano paralelo interno original por causa da orientação variada das colunas e domos que os constituem, o que empresta ao bioerma/biostroma um caráter maciço e compacto ao contrário da estrutura primária acamadada típica da grande maioria das rochas sedimentares. Camadas e lentes de estromatólitos mais finas, sujeitas à mesma deformação intensa, perderam suas estruturas sedimentares muito mais facilmente.

Assim, dentro dos próprios metacalcários, observa-se uma preservação diferenciada devido às diferenças litológicas e de competência. Nas localidades de LAV, NCM, ITN, TGU e IB1 os estromatólitos tem margens bem definidas (Est. XIII-A) e laminação bem preservada, porém de contraste algo apagado devido à dolomitização/recristalização do metadolomito. As porções mais escuras destes estromatólitos representam trechos onde a laminação foi poupada. Estes metacalcários tiveram uma deformação mais rígida e rúptil por causa da maior pureza e, consequentemente, maior competência destes calcários. A orientação dos estromatólitos 
é difícil de ser observada, principalmente sua relação com a estratificação, mas em LAV parece que os estromatólitos foram rotacionados, formando um ângulo de cerca de 30 graus com a estratificação, em vez de 90 graus, como seria de se esperar (Figura 38). Neste caso as colunas estão orientadas a N20E com mergulho de 40 graus para SW e topo apontando para NE (Est. XIII-A), enquanto os metacalcários exibem estratificação com atitude de N40-50E e mergulhos entre 70-80 graus para NW (Figura 19). Na frente ativa da Lavrinhas (Ponto 01), observa-se uma dobra sinforme com eixo a N30E/50 (Figura 38). As ocorrências de estromatólitos de LAV estão situadas no flanco SE desta dobra. A direção das colunas aparentemente é paralela ao eixo deste dobramento, e deste modo seria esperado encontrar estromatólitos em posição mais próxima à original só na zona de charneira desta estrutura.

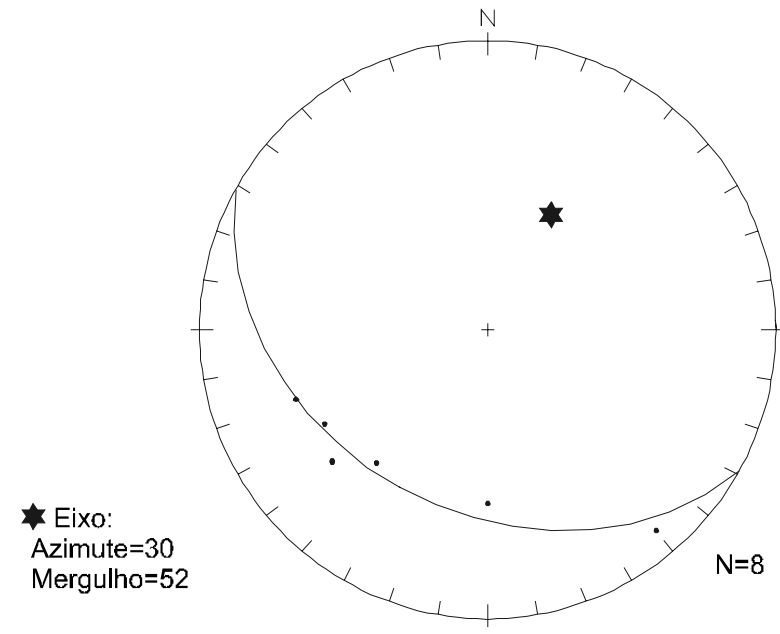

A

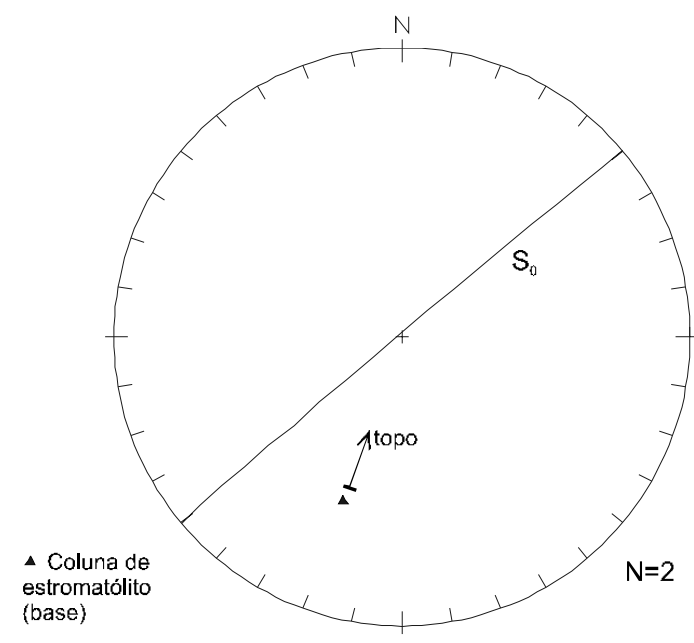

B

Figura 38: Estereogramas de LAV. A - Medidas de acamamento de pedreira ativa de LAV (Pontos 01a, b, c, e). B - Medida de acamamento e direção das colunas de estromatólitos na frente abandonada de LAV (Ponto 02).

Já em IND e CHB a preservação da laminação estromatolítica varia de bem preservada a quase que totalmente apagada com intensa recristalização. As colunas estão deformadas, pois são calcários mais puros do que os sedimentos, mais impuros e menos competentes, entre elas (Est. XIII-B a I). Deste modo, as colunas reagiram a deformação de maneira mais rígida que o sedimento intercolunar. Houve movimentação relativa entre elas, demonstrada por um truncamento apenas de um lado das colunas (Est. XIII-B) e por recristalização nas suas margens (Est. XIII-E), que fez com que os sedimentos intercolunares quase desaparecessem (Est. XIII-B, G e I) e as colunas ficassem dobradas (Est. VIII-B e C; XIII-C e D). Pode-se observar até planos de 
orientação de minerais argilosos (foliação) contidos entre as colunas (Est. IX-B) evidenciando sua deformação mais dúctil (Est. XIII-D, E, F e I). Aparentemente as colunas maiores foram menos deformadas que as menores (Est. VIII-D; XI-D e G).

Em IND ocorrem metacalcários calcíticos compostos essencialmente por estromatólitos, sendo muito difícil observar estratificação (Est. IV-B e D). Nas bordas da pedreira ocorrem filitos (abaixo dos metacalcários), formando aparentemente uma dobra sinforme com eixo a N50E/13, como também mapeado por Theodorovicz et al. (1986). Mas também nas bordas SW e NW da pedreira ocorrem metacalcários intercalados nestes filitos, sem mostrar um padrão de direção de estratificação definido, ao contrário da interpretação de uma estrutura sinformal. A explicação para este fato é que os metacalcários de IND e CHB teria uma forma lenticular de direção NE-SW, gerada por uma deformação diferencial entre os filitos e os metacalcários. Além disso esta forma lenticular pode refletir uma característica da geometria original do bioerma, discutido mais adiante.

A orientação dos estromatólitos dentro dos metacalcários é bastante marcante, estando contidos dentro da foliação plano axial a N50-60E/80NW, com mergulhando 40 graus para SW e topos apontando para NE (Figura 39; Est. IV-B, C e D). Esta foliação se formou entre as colunas, mas se desenvolveu mais em algumas porções, formando um aspecto "amendoado", provavelmente aproveitando espaços maiores entre agrupamentos de colunas (Est. XIII-B).

FSA é um caso particular pois os metacalcários dolomíticos estão bandados tectonicamente, pelo menos em parte, com coloração preta, branca e vermelha, intensamente deformados e recristalizados, com faixas vermelhas estromatolíticas menos recristalizadas, num arranjo em boudins dentro de camadas deformadas (Est. IV). Nas bordas dos boudins, fragmentos estirados de estromatólitos penetram nas faixas mais deformadas (Est. V-F e G). O bandamento está orientado a N65E/65SE com indicadores cinemáticos (sigmóides compostos pelos próprios estromatólitos estirados) mostrando movimentação sinistral. Ocorrem porções brancas com textura grossa devido à recristalização por deformação, por vezes cortando o bandamento. 


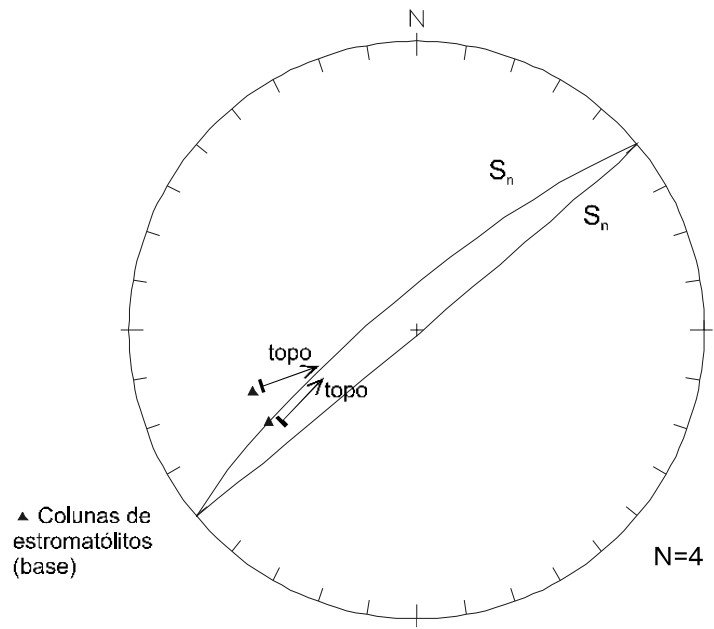

Figura 39: Estereograma de medidas de foliação $\left(S_{n}\right)$ e direção das colunas de estromatólitos em IND.

Especula-se que as camadas mais deformadas podem representar camadas originalmente mais plano-laminadas, talvez estromatólitos estratiformes, ou mais impuras (argilosas), casos estes que promoveriam deformação mais plástica do que nas camadas de estromatólitos colunares. Poderia ter havido, ainda, uma organização planar maior neste caso do que em LAV e IND. Mesmo assim a deformação que atuou nesta localidade parece ter sido muito mais intensa do que nas outras localidades, aproximando-se ao limite para a preservação dos estromatólitos.

\subsection{Cálculo da razão de strain}

Para comparar quantitativamente a deformação nos metacalcários de IND, considerados "mais deformados", com os de LAV, "menos deformados", foram calculadas as "razões de strain", ou seja, a razão entre os eixos menor e maior da elipse de strain (deformação finita). O pressuposto do método aqui aplicado foi de que as seções perpendiculares às colunas dos estromatólitos (seções transversais) eram originalmente aproximadamente circulares ou, no máximo, ligeiramente elípticas. Adotou-se um método expedito proposto por Ramsay \& Huber (1993) que se baseia no seguinte:

- medidas de eixo maior e menor das elipses;

- cálculo da elipsidade $\left(R_{f}\right)$ de cada objeto deformado da seguinte forma:

$$
R_{f}=\frac{\text { eixo maior }}{\text { eixo menor }}
$$


- a razão de strain $\left(R_{S}\right)$ é obtida através da média harmônica dos $R_{f}$.

Ramsay \& Huber (1993) mostram que a aplicação da média harmônica sobre os valores das elipsidades observadas nos objetos deformados fornece, com a vantagem de ser um procedimento bem mais simples, valores de razão de strain $\left(R_{s}\right)$ mais próximos dos valores obtidos pelo método $\mathrm{R}_{\mathrm{f}} / \varnothing$, que é utilizado para medir a razão de strain de objetos originalmente elípticos, baseado na razão entre a elipsidade $\left(R_{f}\right)$ e a orientação das elipses $(\varnothing)$.

O diâmetro original dos estromatólitos foi calculado, com base em Davis \& Reynolds (1996), com a premissa dos objetos serem originalmente circulares e de não ter havido variação de área na seção medida, utilizando:

П.a. $b=\Pi \cdot r^{2} \Rightarrow r^{2}=a \cdot b \Rightarrow r=\sqrt{a \cdot b}$
$2 . r=$ diâmetro

Para IND utilizaram-se 58 medidas de eixo maior e eixo menor de colunas de estromatólitos em corte transversal, tomadas em amostras, em campo e a partir de fotografias (Tabela 12).

No caso de LAV, a medida de estromatólitos foi difícil devido ao grande tamanho das colunas da forma 1 e a forma originalmente alongada da forma 2. Para obter um valor para estes estromatólitos, utilizou-se uma amostra contendo oólitos da região de Bom Sucesso (SP), a cerca de $35 \mathrm{~km}$ a sudeste da área estudada, admitindo uma deformação uniforme nos metacalcários dolomíticos. Foram tomadas 50 medidas de eixo maior e eixo menor (Tabela 13). 


\begin{tabular}{|c|c|c|c|c|c|c|c|c|}
\hline & eixo maior & eixo menor & $\mathrm{d}=$ diâmetro & $R_{f}$ & eixo maior & eixo menor & $\mathrm{d}=$ diâmetro & $R_{f}$ \\
\hline \multirow[t]{20}{*}{1} & 9,50 & 4,50 & 6,538 & 2,111 & 6,00 & 3,00 & 4,243 & 2,000 \\
\hline & 4,50 & 1,50 & 2,598 & 3,000 & 7,50 & 4,50 & 5,809 & 1,667 \\
\hline & 7,50 & 5,00 & 6,124 & 1,500 & 3,75 & 2,25 & 2,905 & 1,667 \\
\hline & 3,80 & 1,50 & 2,387 & 2,533 & 5,25 & 2,25 & 3,437 & 2,333 \\
\hline & 3,60 & 2,00 & 2,683 & 1,800 & 8,25 & 3,75 & 5,562 & 2,200 \\
\hline & 2,50 & 1,40 & 1,871 & 1,786 & 6,00 & 4,50 & 5,196 & 1,333 \\
\hline & 9,00 & 5,50 & 7,036 & 1,636 & 6,00 & 3,75 & 4,743 & 1,600 \\
\hline & 25,00 & 7,00 & 13,229 & 3,571 & 5,25 & 3,75 & 4,437 & 1,400 \\
\hline & 4,50 & 1,30 & 2,419 & 3,462 & 9,00 & 4,50 & 6,364 & 2,000 \\
\hline & 6,00 & 2,00 & 3,464 & 3,000 & 6,75 & 3,75 & 5,031 & 1,800 \\
\hline & 6,50 & 3,00 & 4,416 & 2,167 & 7,50 & 4,50 & 5,809 & 1,667 \\
\hline & 8,50 & 1,50 & 3,571 & 5,667 & 7,50 & 5,25 & 6,275 & 1,429 \\
\hline & 22,00 & 15,00 & 18,166 & 1,467 & 9,75 & 4,50 & 6,624 & 2,167 \\
\hline & 20,00 & 8,00 & 12,649 & 2,500 & 5,25 & 3,75 & 4,437 & 1,400 \\
\hline & 22,00 & 16,00 & 18,762 & 1,375 & 7,50 & 3,00 & 4,743 & 2,500 \\
\hline & 7,00 & 4,50 & 5,612 & 1,556 & 9,75 & 3,75 & 6,047 & 2,600 \\
\hline & 5,00 & 2,50 & 3,536 & 2,000 & 6,75 & 2,25 & 3,897 & 3,000 \\
\hline & 8,50 & 3,00 & 5,050 & 2,833 & 7,50 & 3,00 & 4,743 & 2,500 \\
\hline & 5,00 & 3,00 & 3,873 & 1,667 & 6,75 & 3,75 & 5,031 & 1,800 \\
\hline & 32,00 & 20,00 & 25,298 & 1,600 & 8,25 & 5,25 & 6,581 & 1,571 \\
\hline \multirow[t]{6}{*}{2} & 21,00 & 12,00 & 15,875 & 1,750 & 5,25 & 3,00 & 3,969 & 1,750 \\
\hline & 17,00 & 8,50 & 12,021 & 2,000 & 5,25 & 3,75 & 4,437 & 1,400 \\
\hline & 28,00 & 18,00 & 22,450 & 1,556 & 8,25 & 3,00 & 4,975 & 2,750 \\
\hline & 11,00 & 7,00 & 8,775 & 1,571 & 5,25 & 2,25 & 3,437 & 2,333 \\
\hline & 9,00 & 8,00 & 8,485 & 1,125 & 8,25 & 3,75 & 5,562 & 2,200 \\
\hline & 12,00 & 6,00 & 8,485 & 2,000 & 6,75 & 3,00 & 4,500 & 2,250 \\
\hline \multirow[t]{3}{*}{3} & 7,50 & 3,75 & 5,303 & 2,000 & 8,25 & 3,00 & 4,975 & 2,750 \\
\hline & 5,25 & 3,75 & 4,437 & 1,400 & 7,50 & 3,75 & 5,303 & 2,000 \\
\hline & 6,75 & 3,75 & 5,031 & 1,800 & 7,50 & 3,00 & 4,743 & 2,500 \\
\hline & & & & & & & 6,620 & $R_{S}=1,912$ \\
\hline & & & & & & & $\begin{array}{l}\text { Diâmetro } \\
\text { médio }\end{array}$ & $\begin{array}{c}\text { Média } \\
\text { harmônica } \\
\text { dos } R_{f}\end{array}$ \\
\hline
\end{tabular}

Tabela 12: Medidas (em $\mathrm{cm} ; \mathrm{N}=58$ ) dos eixos maior e menor de colunas de estromatólitos em corte transversal de IND, com os cálculos de diâmetro, $R_{f}$ e $R_{s}$. 1- medidas em amostras; 2medidas de campo; 3- medidas em fotografia (Est. XIII-G) 


\begin{tabular}{|c|c|c|c|c|c|c|c|}
\hline eixo maior & eixo menor & $\mathrm{D}=$ diâmetro & $\mathrm{R}_{\mathrm{f}}$ & eixo maior & eixo menor & $\mathrm{d}=$ diâmetro & $R_{f}$ \\
\hline 0,40 & 0,16 & 0,253 & 2,500 & 0,28 & 0,16 & 0,212 & 1,750 \\
\hline 0,40 & 0,32 & 0,358 & 1,250 & 0,32 & 0,24 & 0,277 & 1,333 \\
\hline 0,32 & 0,28 & 0,299 & 1,143 & 0,40 & 0,24 & 0,310 & 1,667 \\
\hline 0,16 & 0,16 & 0,160 & 1,000 & 0,24 & 0,16 & 0,196 & 1,500 \\
\hline 0,24 & 0,24 & 0,240 & 1,000 & 0,40 & 0,32 & 0,358 & 1,250 \\
\hline 0,20 & 0,16 & 0,179 & 1,250 & 0,40 & 0,32 & 0,358 & 1,250 \\
\hline 0,16 & 0,16 & 0,160 & 1,000 & 0,56 & 0,40 & 0,473 & 1,400 \\
\hline 0,20 & 0,12 & 0,155 & 1,667 & 0,40 & 0,16 & 0,253 & 2,500 \\
\hline 0,20 & 0,12 & 0,155 & 1,667 & 0,32 & 0,24 & 0,277 & 1,333 \\
\hline 0,40 & 0,32 & 0,358 & 1,250 & 0,32 & 0,24 & 0,277 & 1,333 \\
\hline 0,40 & 0,32 & 0,358 & 1,250 & 0,32 & 0,12 & 0,196 & 2,667 \\
\hline 0,24 & 0,16 & 0,196 & 1,500 & 0,32 & 0,32 & 0,320 & 1,000 \\
\hline 0,40 & 0,16 & 0,253 & 2,500 & 0,40 & 0,24 & 0,310 & 1,667 \\
\hline 0,20 & 0,16 & 0,179 & 1,250 & 0,24 & 0,20 & 0,219 & 1,200 \\
\hline 0,16 & 0,12 & 0,139 & 1,333 & 0,28 & 0,08 & 0,150 & 3,500 \\
\hline 0,24 & 0,24 & 0,240 & 1,000 & 0,40 & 0,24 & 0,310 & 1,667 \\
\hline 0,32 & 0,32 & 0,320 & 1,000 & 0,40 & 0,36 & 0,379 & 1,111 \\
\hline 0,20 & 0,16 & 0,179 & 1,250 & 0,40 & 0,24 & 0,310 & 1,667 \\
\hline 0,32 & 0,24 & 0,277 & 1,333 & 0,40 & 0,40 & 0,400 & 1,000 \\
\hline 0,24 & 0,16 & 0,196 & 1,500 & 0,24 & 0,20 & 0,219 & 1,200 \\
\hline 0,16 & 0,16 & 0,160 & 1,000 & 0,40 & 0,40 & 0,400 & 1,000 \\
\hline 0,24 & 0,32 & 0,277 & 0,750 & 0,40 & 0,32 & 0,358 & 1,250 \\
\hline 0,24 & 0,16 & 0,196 & 1,500 & 0,24 & 0,16 & 0,196 & 1,500 \\
\hline 0,24 & 0,16 & 0,196 & 1,500 & 0,32 & 0,16 & 0,226 & 2,000 \\
\hline 0,28 & 0,16 & 0,212 & 1,750 & & & 0,258 & $R_{s}=1,338$ \\
\hline 0,24 & 0,20 & 0,219 & 1,200 & & & Diâmetro & Média \\
\hline
\end{tabular}

Tabela 13: Medidas (em cm; $\mathrm{N}=50$ ) de eixo maior e menor para oólitos da região de Bom Sucesso de Itararé (SP), tomados a partir de fotografia, com os cálculos de diâmetro, $R_{f}$ e $R_{S}$.

Como visto na tabela 12, os valores de $R_{f}$ em IND variam entre de 1,13 e 5,67 (Est. XIII-H), com $R_{s}$ igual a 1,91. Já nos oólitos os valores de $R_{f}$ variam entre 1 e 3,5, com $R_{s}$ igual a 1,34 (Tabela 13), ou seja, os valores de $R_{\mathrm{s}}$ obtidos para os estromatólitos de IND são maiores que os obtidos através da análise dos oólitos deformados, considerados como próximos aos de LAV. Os valores de deformação finita obtidos podem ser considerados baixos em LAV a moderados em IND.

As medidas de ângulo apical obtidas para estromatólitos coniformes (Forma 1) também podem ser utilizadas para calcular razões de strain. Em LAV o ângulo apical médio (8 medidas) é de $60^{\circ}$ no eixo maior e $40^{\circ}$ (Est. VII-B) no eixo menor, indicando uma razão de strain de 1,5. Em IND o ângulo apical médio é de $40^{\circ}$ (Est. VIII-D e E) no eixo maior e $20^{\circ}$ no eixo menor, indicando uma razão de strain de 2,0. Além disso, em LAV, imaginando-se que os estromatólitos eram originalmente circulares e assumindo que não ocorreu muita mudança no volume, pode-se calcular seu ângulo apical original como de aproximadamente $50^{\circ}$, calculado graficamente. Desta forma, admitindo que as formas coniformes em IND eram semelhantes às de LAV, os ângulos apicais nas formas de IND 
foram diminuídos pela deformação, ou seja, ocorreu um achatamento das colunas. No caso de CHB, citado anteriormente, o achatamento foi extremo, chegando a formar ângulos de até $15^{\circ}$ no eixo menor (Est. VIII-F). Estas mudanças de ângulos apicais indicam que o relevo sinótico também foi alterado e onde o ângulo apical medido é menor que o original, o relevo sinótico relatado na descrição da Forma 1 deve ser maior que o original.

Da mesma maneira que os estromatólitos cônicos (Forma 1), as outras formas também foram deformadas. Esta deformação teve reflexo nas formas 2 e 3 com um achatamento, aumentando as elipsidades das colunas e a convexidade da laminação. Em alguns casos a laminação parabólica pode ser um resultado da deformação.

A suspeita de que em IND as colunas maiores apresentavam de modo geral uma deformação menor foi testada através da análise das elipsidades $\left(R_{\mathrm{f}}\right)$, como demonstrado. Observa-se na Figura 40 que de modo geral as colunas maiores, principalmente quando maiores que $15 \mathrm{~cm}$ de diâmetro, são menos deformadas enquanto as menores tendem a apresentar-se mais deformadas.

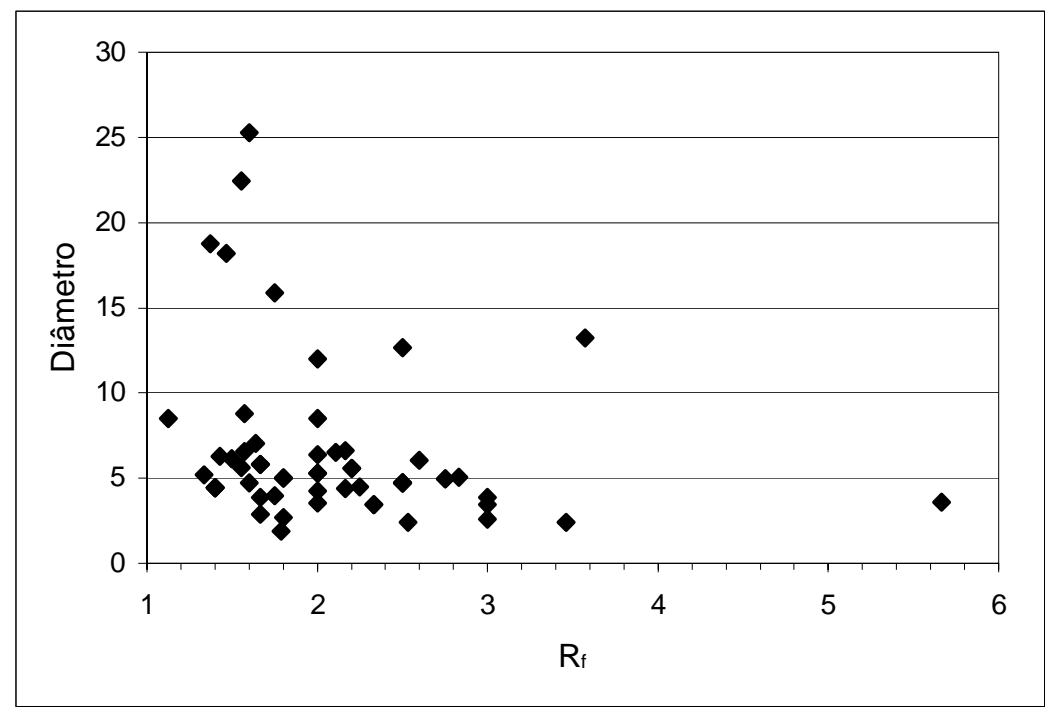

Figura 40: Relação das elipsidades $\left(\mathrm{R}_{\mathrm{f}}\right)$ com os diâmetros originais teóricos, para cada coluna medida em IND.

Ainda em IND foi aplicado na Est. XIII-G o método gráfico de Fry (1979) para obtenção de $R_{s}$, baseado na distribuição dos centros das elipses vizinhas (Figura 41). 


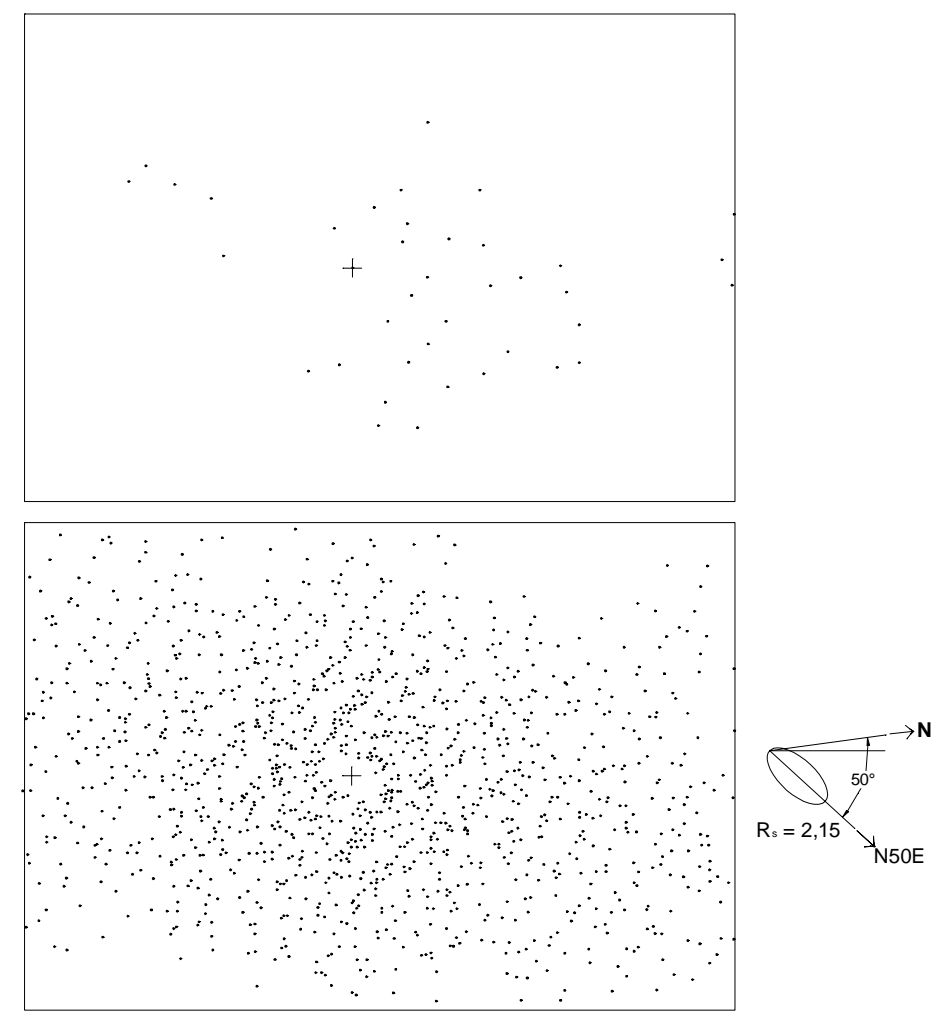

Figura 41: Aplicação do método de Fry (1979) em estromatólitos de IND, baseado na fotografia na Est. XIII-G. A - Centros das elipses das colunas de estromatólitos em corte basal. B- Diagrama final mostrando a distribuição dos pontos formando uma elipse no centro da figura, representada ao lado com o respectivo valor de $\mathrm{R}_{\mathrm{s}}$ e de orientação.

Através deste método obteve-se $\mathrm{R}_{\mathrm{S}}$ igual a 2,15 mostrando graficamente a forma e a orientação da elipse média. A orientação desta eixo maior da elipse corresponde a orientação da foliação e dos estromatólitos, em torno de N50E. O valor de $R_{S}$ obtido por este método é um pouco maior que o valor de $R_{S}$ obtido pela média harmônica das elipsidades. Isto se explica pela deformação nos espaços entre as colunas (sedimento intercolunar argiloso) ter sido maior que a deformação das colunas, já que o método centro a centro (método de Fry, 1979) registra a deformação total, e o das elipsidades, apenas o das colunas.

O valor de $R_{S}$ de 1,34 (variando entre 1 e 3,5) obtido para oólitos do Grupo Itaiacoca é mais baixo que os valores médios de $R_{S}$ de 1,58 (variando entre 1,28 e 1,91; atingindo até 2,78 próximo às zonas de falha) encontrados por Campanha (1991) em rochas do Subgrupo Lajeado (mais a sudeste). Estes valores podem ter sido mais elevados devido ao fato de que foram obtidos tanto em rochas siliciclásticas (metarenitos e metassiltitos) quanto em metacalcários. Analisados separadamente, os valores de $R_{S}$ obtidos por Campanha (1991) caem para 1,49 em média nos metacalcários e sobem para 1,65 nas rochas siliciclásticas. $O$ valor de $R_{S}$ de 1,91 obtido em IND é mais elevado do 
que aqueles encontrados em metacalcários do Subgrupo Lajeado. Deste modo pode-se dizer que o valor de $\mathrm{R}_{\mathrm{s}}$ obtido para os oólitos pode ser considerado, grosso modo, como um valor mais próximo a um valor médio para o Grupo Itaiacoca, sendo que o valor de $R_{S}$ para IND, é um valor restrito a esta localidade. 
ESTAMPA XIII - Aspectos da deformação dos estromatólitos de IND e LAV

A - LAV - Colunas de Conophyton em corte longitudinal, na frente de lavra abandonada do ponto 02. Estas colunas estão orientadas na direção N20E com mergulho de 40 graus para SW e topo apontando para NE. A escala corresponde a $15 \mathrm{~cm}$.

B - IND - Superfície intemperisada mostrando diversas colunas de Conophyton em corte oblíquo, intensamente estiradas, com o espaço intercolunar encurtado e o sedimento contido nele moldado entre as colunas. Observar a tendência do lado superior das colunas (nesta foto) apresentar-se cisalhado. A escala corresponde a $15 \mathrm{~cm}$. Fotografia tomada por T.R. Fairchild.

C - IND - Superfície intemperisada mostrando diversas colunas dobradas.

D - IND - Superfície intemperisada mostrando diversas colunas deformadas, em corte longitudinal, com a laminação e o sedimento intercolunar ressaltada pelo intemperismo. Esta superfície a aproximadamente paralela ao plano de foliação e os estromatólitos estão cortados no seu eixo maior. A tampa da câmera possui $6 \mathrm{~cm}$ de diâmetro. Fotografia tomada por T.R. Fairchild.

E - IND - Amostra com algumas colunas de Conophyton, estiradas, com a laminação cônica acentuada pela deformação. As margens das colunas apresentam recristalização. Amostra IND-07.

F - IND - Superfície intemperisada mostrando diversas colunas, em corte longitudinal, com a deformação evidenciada pela laminação irregular. A laminação estromatolítica foi ressaltada com caneta hidrográfica. Fotografia tomada por T.R. Fairchild.

G - IND - Diversas colunas agrupadas (orientadas na direção aproximada de N50E), em corte transversal, exibindo forma elíptica devido a deformação,. A escala corresponde a $15 \mathrm{~cm}$.

H - IND - Corte transversal de uma coluna elíptica intensamente deformada, com razão de strain $\left(\mathrm{R}_{\mathrm{f}}\right)$ de 5,67. Amostra IND-15.

I - IND - Corte transversal de diversas colunas elípticas deformadas. Observar o estiramento e a cataclase de algumas colunas. A escala corresponde a $2 \mathrm{~cm}$. Amostra IND-09. 
A

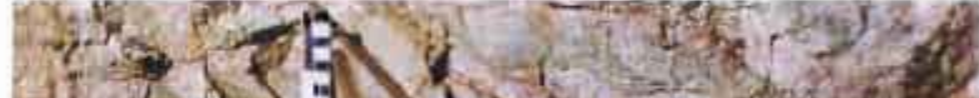

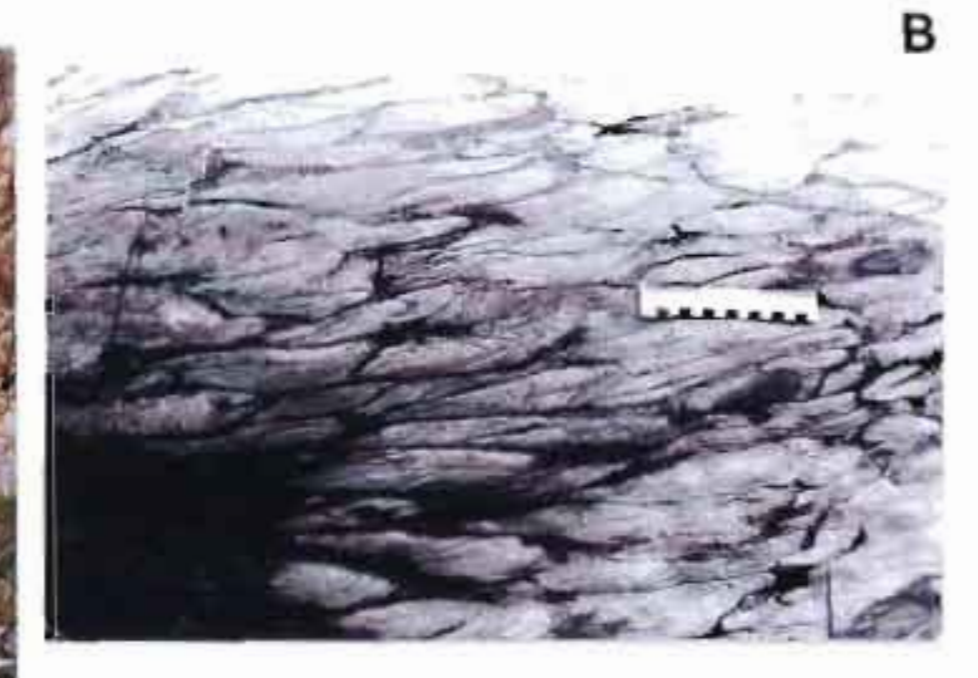

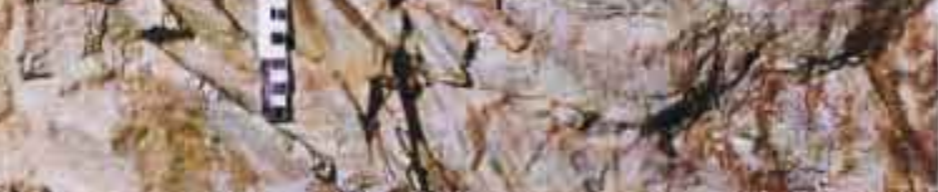
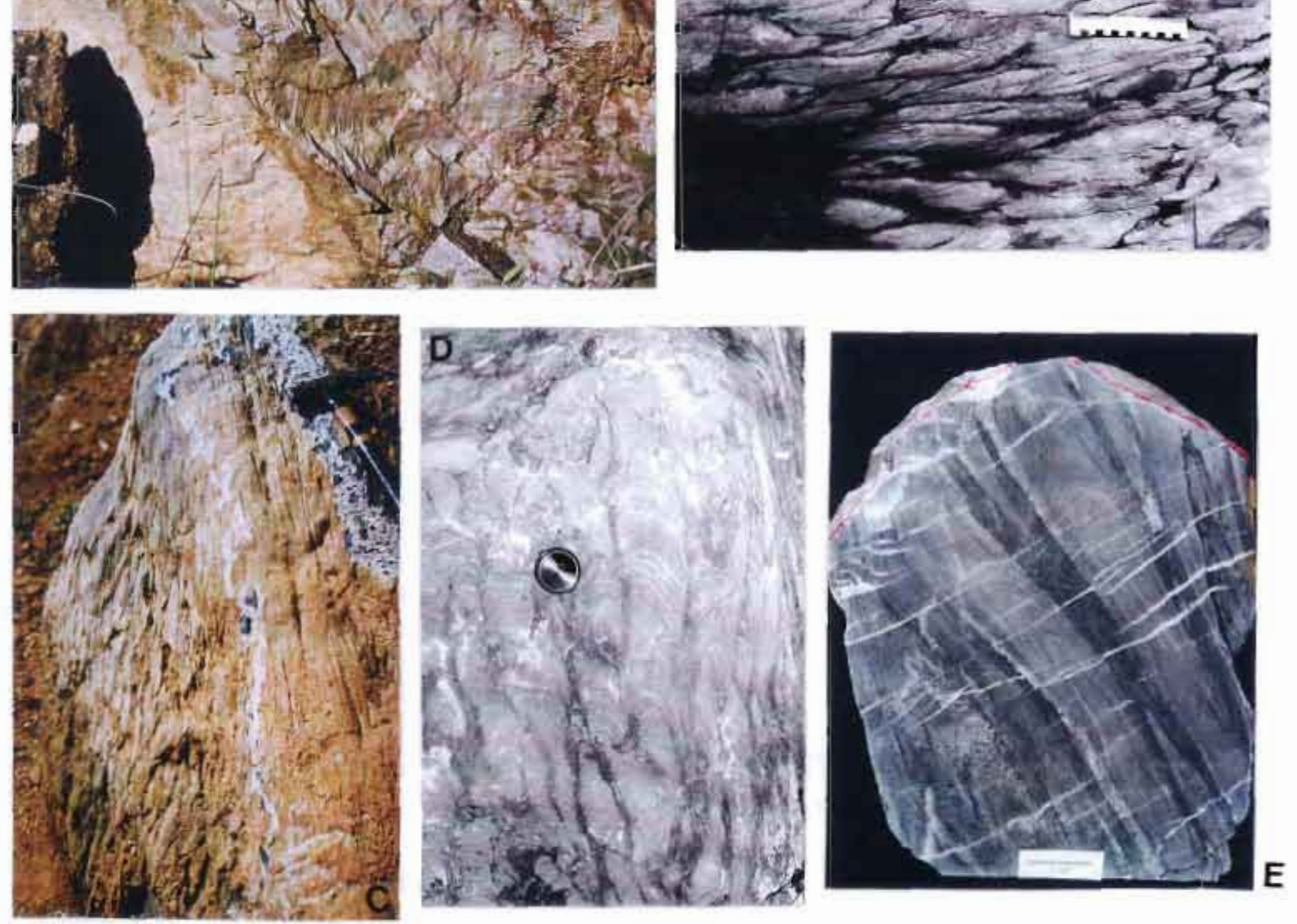

F
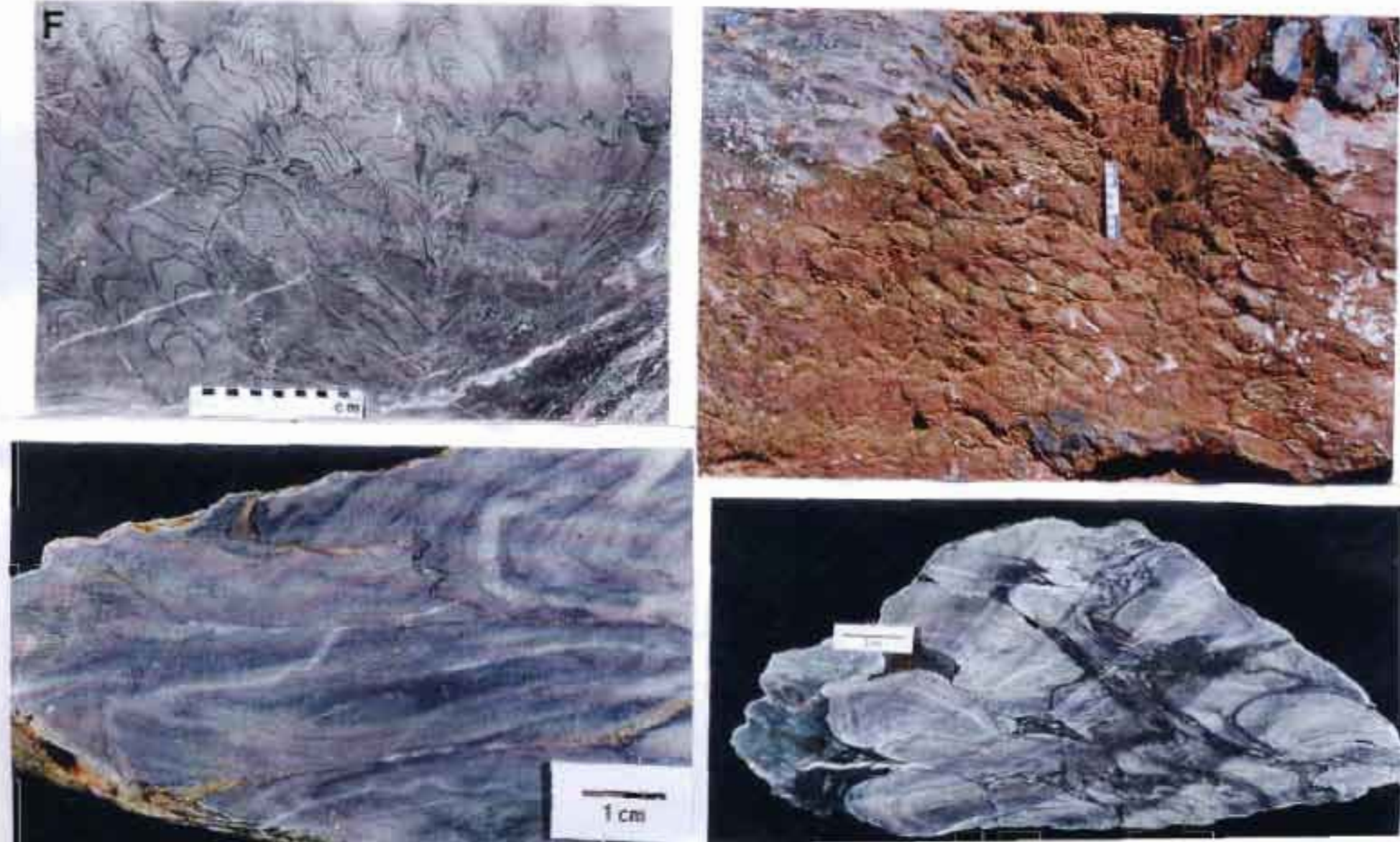


\section{COMPARAÇÃO COM OUTRAS LOCALIDADES}

O uso de estromatólitos como elemento para correlação regional já foi demonstrado por diversos autores, desde correlações dentro de uma mesma bacia (Bertrand-Sarfati \&Trompette, 1976) ou até entre continentes (Preiss, 1976b). O estudo de Conophyton de diversas localidades no mundo demonstrou que ocorre uma concentração de certas formas em períodos específicos de tempo (Preiss, 1976b). Por exemplo, segundo Preiss (1976b), as formas de Conophyton já identificadas no Brasil (Moeri, 1972; Cloud \& Moeri, 1973; Fairchild, 1977) indicariam idades mesoproterozóicas: C. cylindricum e C. garganicum ocorrem entre 1,6 a 1,0 Ga e C. metulum entre 1,3 a 1,0 Ga.

Como ocorrem formas descritas de Conophyton tanto no Grupo Itaiacoca da Faixa Ribeira (Fairchild, 1977) quanto no Grupo Paranoá da Faixa Brasília (Moeri, 1972; Cloud \& Dardenne, 1973; Cloud \& Moeri, 1973), foi realizada uma análise destas formas para fins de comparação.

\subsection{Grupo Itaiacoca}

Como já discutido no item 5 , estromatólitos já foram descritos em diversas partes do Grupo Itaiacoca, porém além da região de Itapeva, Conophyton ocorre apenas na região de Abapã (Fairchild, 1977). As três amostras analisadas no presente capítulo são justamente de duas localidades desta área. A primeira localidade é na margem SE do Rio do Morcego, a cerca de $8 \mathrm{~km}$ S80E de Abapã (Figura 42, Ponto 1; Figura 17, Ponto 13), de onde provêm as amostras CABA-03 e CABA-04. Parece representar uma das localidades descritas por Almeida (1957), posteriormente visitada por Fairchild (1977, ponto 7).

A segunda está localizada na margem NE do Ribeirão das Areias a cerca de $6 \mathrm{~km}$ de Abapã, na direção S20E (Figura 42, Ponto 2; Figura 17, Ponto 14). Apenas uma amostra desta localidade foi analisada (CABA-02). Esta localidade parece representar uma das localidades descritas por Almeida (1957) e deve ser a localidade descrita por Marini \& Bósio (1971), também descrita por Fairchild (1977, ponto 8). 


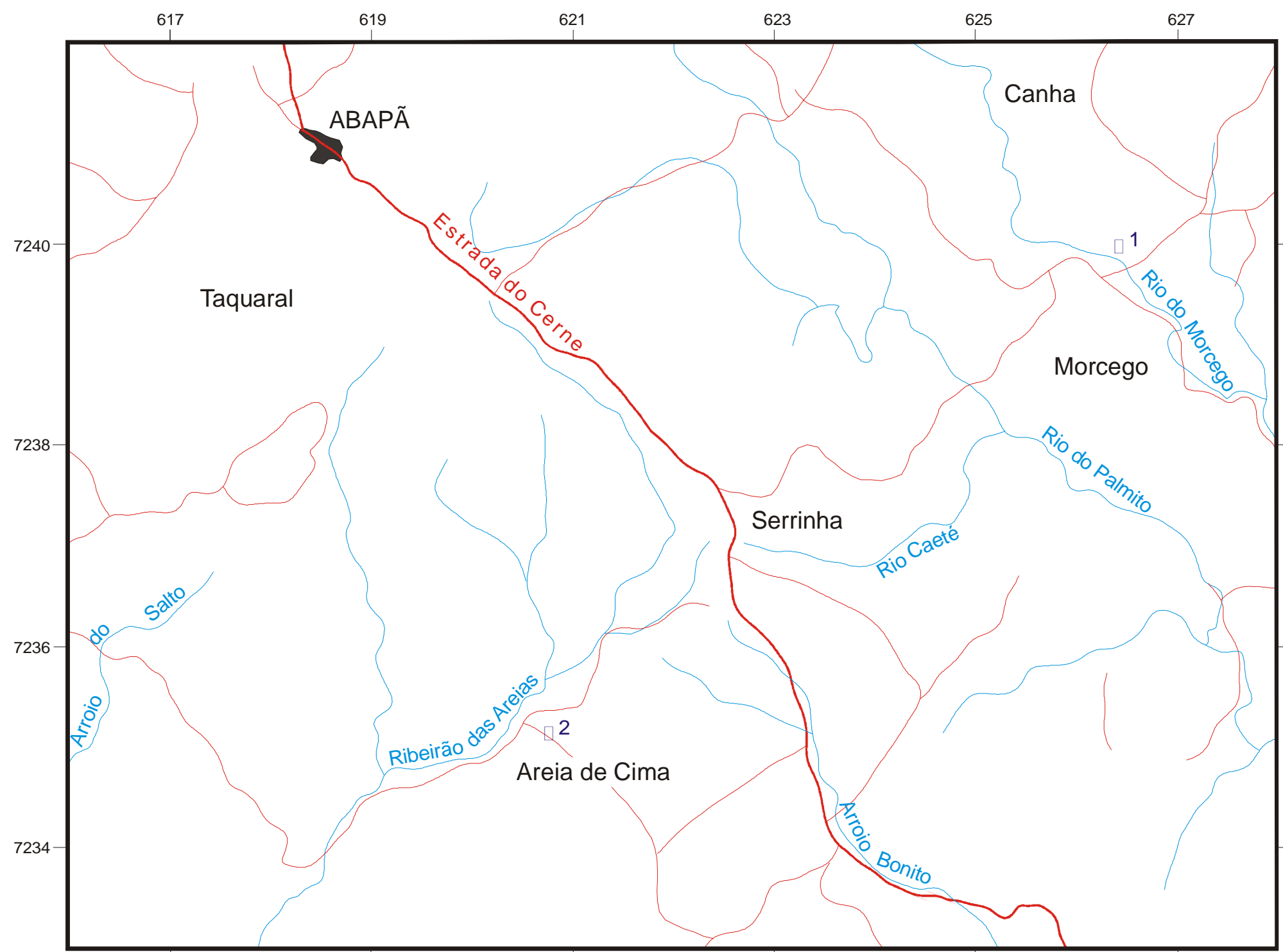

\section{Legenda}

- Estrada principal

Estradas secundárias Drenagem

2 Cidades

- Ocorrências de estromatólitos:

1 Rio do Morcego

2 Ribeirão das Areias

Figura 42: Mapa de localização das ocorrências de Conophyton no Grupo Itaiacoca na região de Abapã (PR). 
As amostras analisadas (CABA-02, 03 e 04) são muito semelhantes às formas de Conophyton identificadas em Itapeva, mas de modo geral são menos deformadas. Todas são compostas de metacalcário dolomítico. Os estromatólitos ocorrem próximas (H.2), com espaço intercolunar de cerca de 1 a 2 cm (Est. XIV-C). São colunas cilíndricas (C.5), com contornos transversais circulares (F.1) a elípticos (F.3), com valores máximos de 13 $\mathrm{cm}$ no eixo menor e $18 \mathrm{~cm}$ no eixo maior (Est. XIV-C). Em perfil longitudinal são pontiagudos com zona axial (N.8), formando um ângulo apical de $40^{\circ}$ no eixo menor, a $70^{\circ}$ no eixo maior, e relevo sinótico alto com no mínimo $16 \mathrm{~cm}$ (Est. XIV-A e B). A zona axial é estreita, com 0,4 a 0,6 cm de espessura (Est. XIV-A e B). Os traços axiais indicam um grau de regularidade e de herança laminar alto a médio (Figura 43).

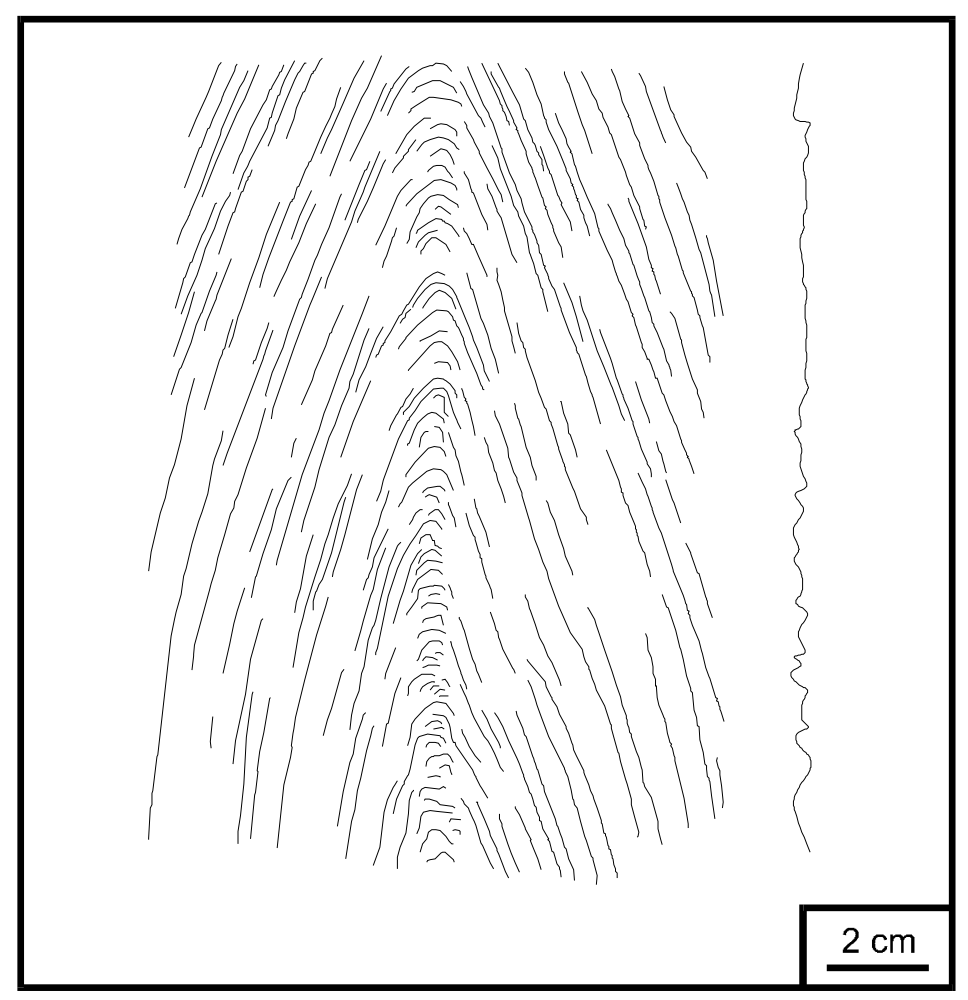

Figura 43: Zona axial e seu respectivo traço axial na amostra CABA-03 (Est. XIV-A).

Em lâmina petrográfica observa-se uma laminação fina e mal preservada (Est. XIVB e D). A espessura de L2 (lâminas escuras) varia entre 0,04 e 0,5 mm (55 medidas) e de L1 (lâminas claras) entre 0,04 e 0,76 mm (52 medidas) (Figura 44). Há maior concentração entre 0,04 e 0,3 mm, com picos em 0,14 e 0,26 mm, para L2, e entre 0,04 e 0,4 mm, com pico em 0,15, para L1. 


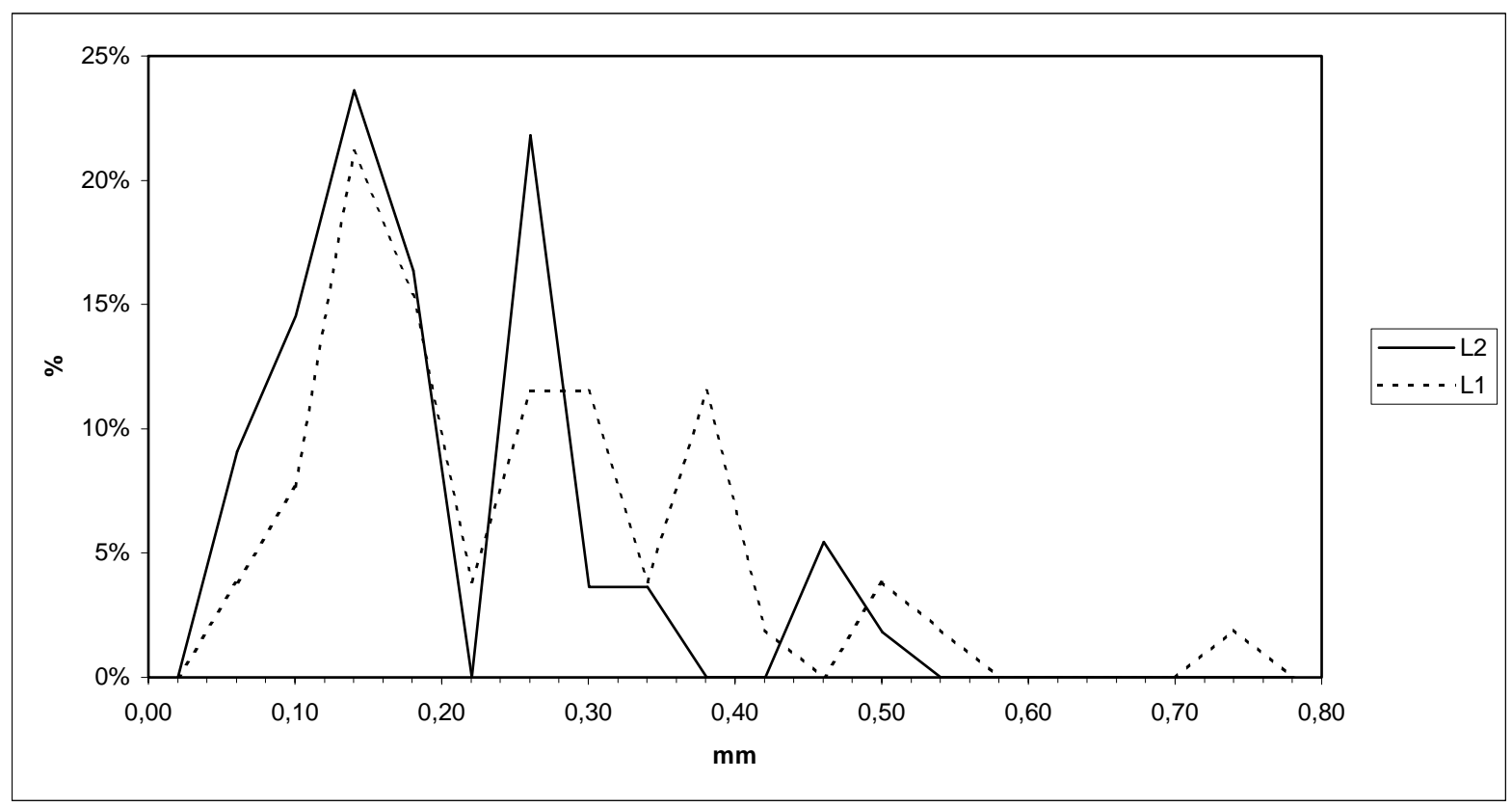

Figura 44: Freqüência relativa das lâminas escuras (L2) e claras (L1) da amostra CABA-03, Abapã, PR. N=55 (L2) e 52 (L1).

Um desenho da laminação elaborado a partir de fotografia de lâmina petrográfica (Est. XIV-D) mostra bem o aspecto da laminação fina e a distribuição das lâminas claras e escuras (Figura 45). A laminação escura encontra-se muito deteriorada e originalmente deve ter sido mais abundante.

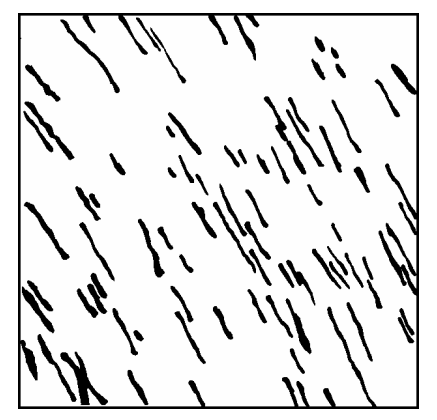

Figura 45: Desenho da laminação elaborado a partir de fotografia de lâmina petrográfica da amostra CABA-03, Abapã, PR (Est. XIV-D). A área do desenho corresponde a $1 \mathrm{~cm}^{2}$. 
ESTAMPA XIV - Conophyton de Abapã, PR

A - Corte longitudinal de uma coluna de Conophyton, com detalhe da zona axial. Amostra CABA-03.

B - Corte longitudinal de uma coluna de Conophyton, com detalhe da zona axial, em lâmina petrográfica. Amostra CABA-03.

C - Corte transversal de algumas colunas de Conophyton, com contornos arredondados. Amostra CABA-02.

D - Detalhe mostrando parte de uma coluna, em corte longitudinal, com a laminação fina e mal definida. Amostra CABA-03. 

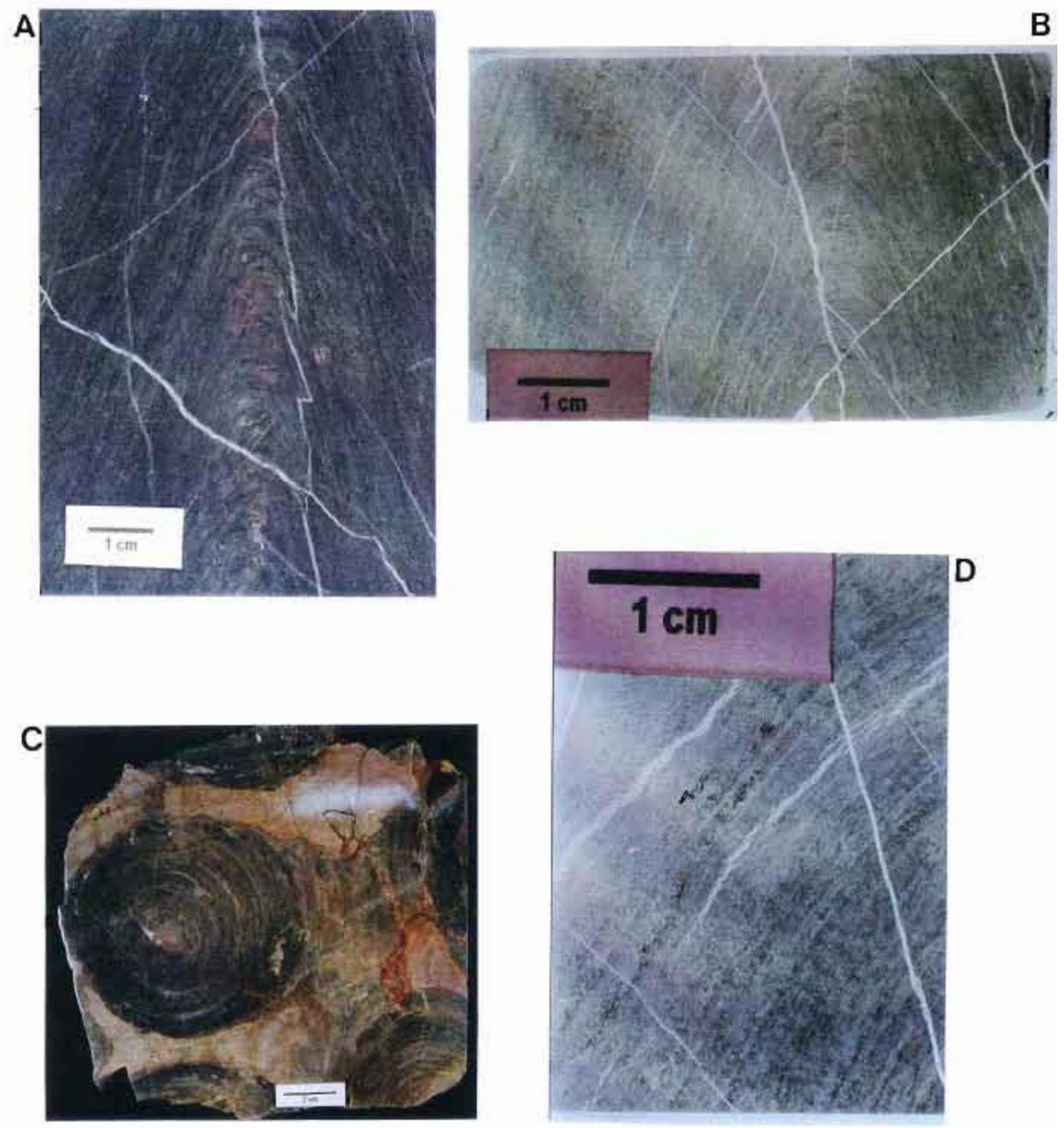


\subsection{Grupo Paranoá (MG-GO)}

O Grupo Paranoá é uma unidade metassedimentar geralmente pouco deformada que ocorre na zona externa da Faixa Brasília, inserido em um cinturão de dobras e falhas de empurrão (Fuck, 1994). Na região de Alto Paraíso (GO), comporta nove formações segundo Dardenne e Faria (1985). Estromatólitos cônicos (Conophyton) ocorrem na formação de topo.

Tem uma idade de sedimentação que gira em torno do Mesoproterozóico superior e do Neoproterozóico inferior, estabelecida principalmente com base em quatro pontos:

1- O Grupo Araí, inferior ao Grupo Paranoá, tem idades de metamorfismo obtidas pelo método $\mathrm{Rb} / \mathrm{Sr}$ em rochas metavulcânicas em torno de $1170 \pm 24 \mathrm{Ma}$ (Tassinari et al., 1981) e 1140 Ma (Reis Neto, 1983; Fuck et al., 1988);

2- Estromatólitos encontrados no Grupo Paranoá relacionados às formas Conophyton cylindricum (Moeri, 1972; Cloud \& Moeri, 1973) e C. metulum (Dardenne \& Campos Neto, 1976), tem sido assinalados geralmente em unidades com idades entre 1,6 a 1,0 Ma (Preiss, 1976b);

3- Os sedimentos glaciogênicos da Formação Jequitaí, diretamente acima do Grupo Paranoá, podem ser equivalente à Formação Bebedouro (também glacial) que tem idades obtidas em argilas de $932 \pm 30$ e $911 \pm 27 \mathrm{Ma}$, pelo método $\mathrm{Rb} / \mathrm{Sr}$ e $901 \pm 21$ e $876 \pm 20 \mathrm{Ma}$, pelo método $\mathrm{K} / \mathrm{Ar}$ (Macedo \& Bonhomme, 1984).

4- Simonetti \& Fairchild (no prelo) interpretaram a associação de microfósseis orgânicos da unidade correlata, o Grupo Conselheiro Mata, como coerente com uma provável idade mesoproterozóica.

Desta forma a idade do Grupo Paranoá situa-se entre 1170 a $950 \mathrm{Ma}$, possuindo assim uma idade próxima à idade do Grupo Itaiacoca.

Foram analisadas amostras de três localidades do Grupo Paranoá ou de seus equivalentes na região de Vazante, MG (Figura 46), todas de metacalcários dolomíticos. 
$47^{\circ} 00^{\prime}$

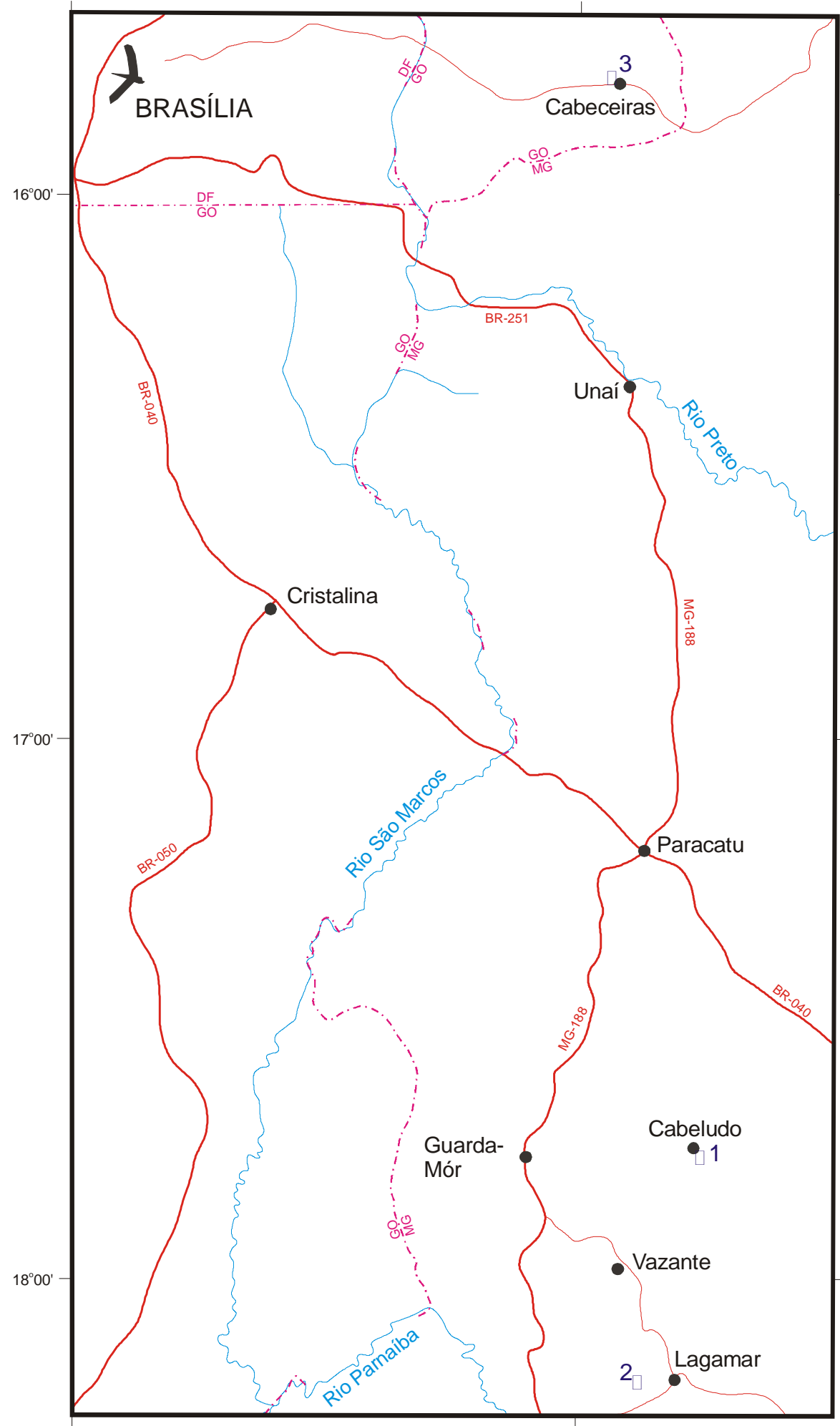

Legenda

- Estradas principais

Estradas secundárias

Rios principais

-.. Divisas de estado

- Cidades

Ocorrências

de Conophyton:

1 Cabeludo

2 Lagamar

3 Cabeceiras

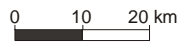

Figura 46: Mapa de localização de algumas ocorrências de Conophyton no Grupo Paranoá em Minas Gerais e Goiás. 
A primeira está situada a cerca de $30 \mathrm{~km}$ a N30E de Vazante (MG), em um local conhecido como Cabeludo e foi descrita por Moeri (1972) e Cloud \& Dardenne (1973) (Figura 46, Ponto 1). Moeri (1972) classificou estes estromatólitos como Conophyton cylindricum e Cloud \& Dardenne (1973) como C. metulum. Posteriormente Cloud \& Moeri (1973) optaram pela manutenção da primeira denominação de C. cylindricum. A amostra analisada desta localidade (CPAR-05) consiste de uma coluna cilíndrica (C.5), com contorno transversal elíptico (F.3) (Est. XV-B), com eixo menor de $15 \mathrm{~cm}$ e eixo maior de $12 \mathrm{~cm}$ (Est. XV-A e C). Em perfil longitudinal é pontiagudo com zona axial mal definida (N.8), formando um ângulo apical de 60 a $70^{\circ}$ no eixo maior, e com relevo sinótico alto de no mínimo $13 \mathrm{~cm}$ (Est. XV-A e C). A zona axial é estreita, com até 0,5 cm de largura(Est. $\mathrm{XV}-\mathrm{A}, \mathrm{B}$ e $\mathrm{C}$ ). Os traços axiais indicam um grau de regularidade e de herança laminar alto a médio (Figura 48 A). A amostra exibe padrão milimétrico de faixa claras e escuras (Est. XV-A a D) que geralmente não corresponde a laminação clara e escura e sim a uma estrutura secundária de recristalização, responsável pelas lâminas claras. Dentro das faixas escuras a laminação original está melhor preservada. Em lâmina petrográfica observa-se uma laminação não muito fina e mal preservada (Est. XV-B e D). A espessura de L2 varia entre 0,04 e 1,3 mm (105 medidas) e de L1 entre 0,04 e 1,0 mm (106 medidas) (Figura 47). Há maior concentração entre 0,04 e 0,3 mm, com picos em 0,14 e 0,18 mm, para L2, e entre 0,04 e 0,4 mm, com picos em 0,15 e 0,25 mm, para L1.

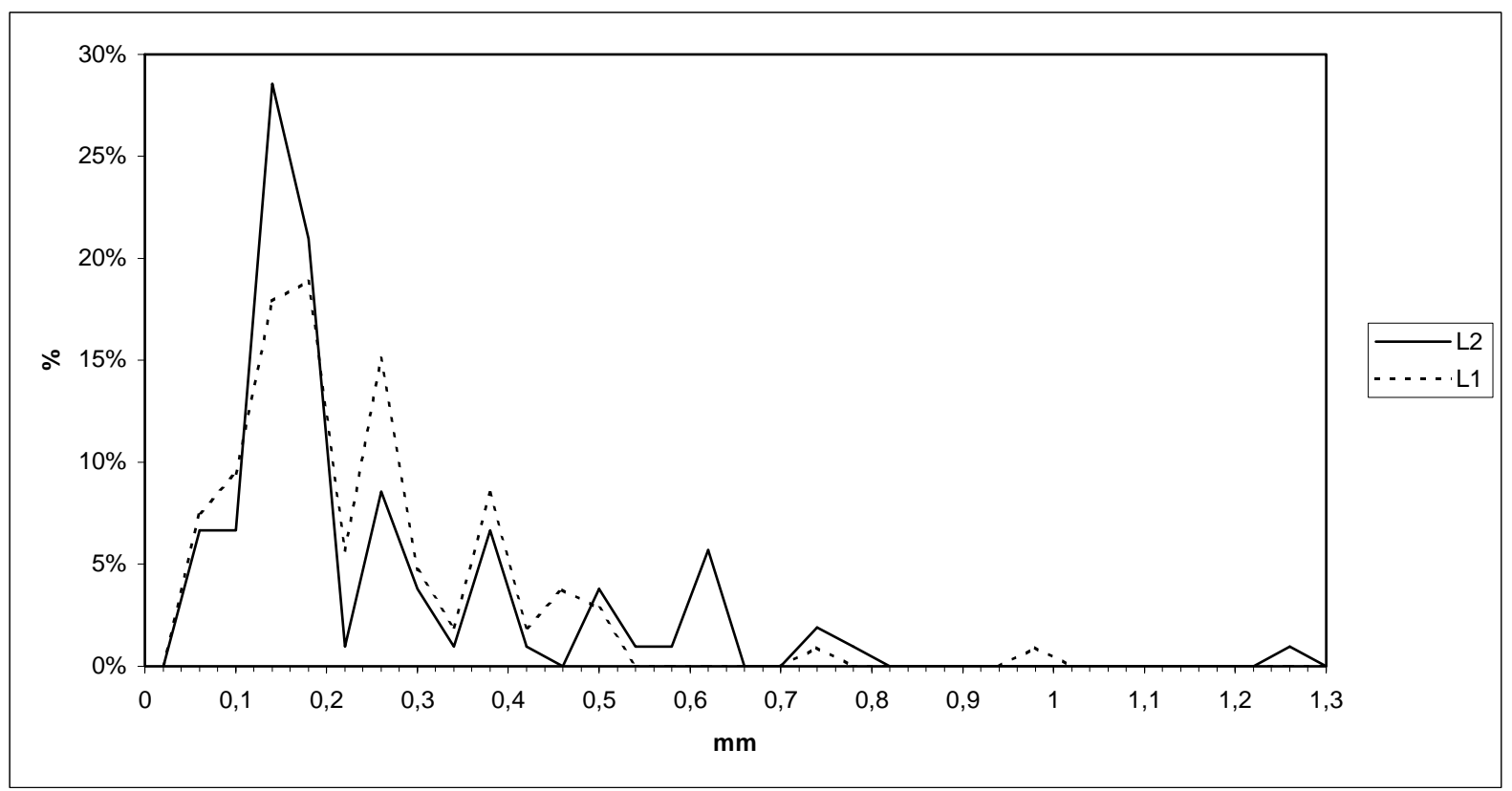

Figura 47: Freqüência relativa das lâminas escuras (L2) e claras (L1) da amostra CPAR-05. $\mathrm{N}=105$ (L2) e 106 (L1). 


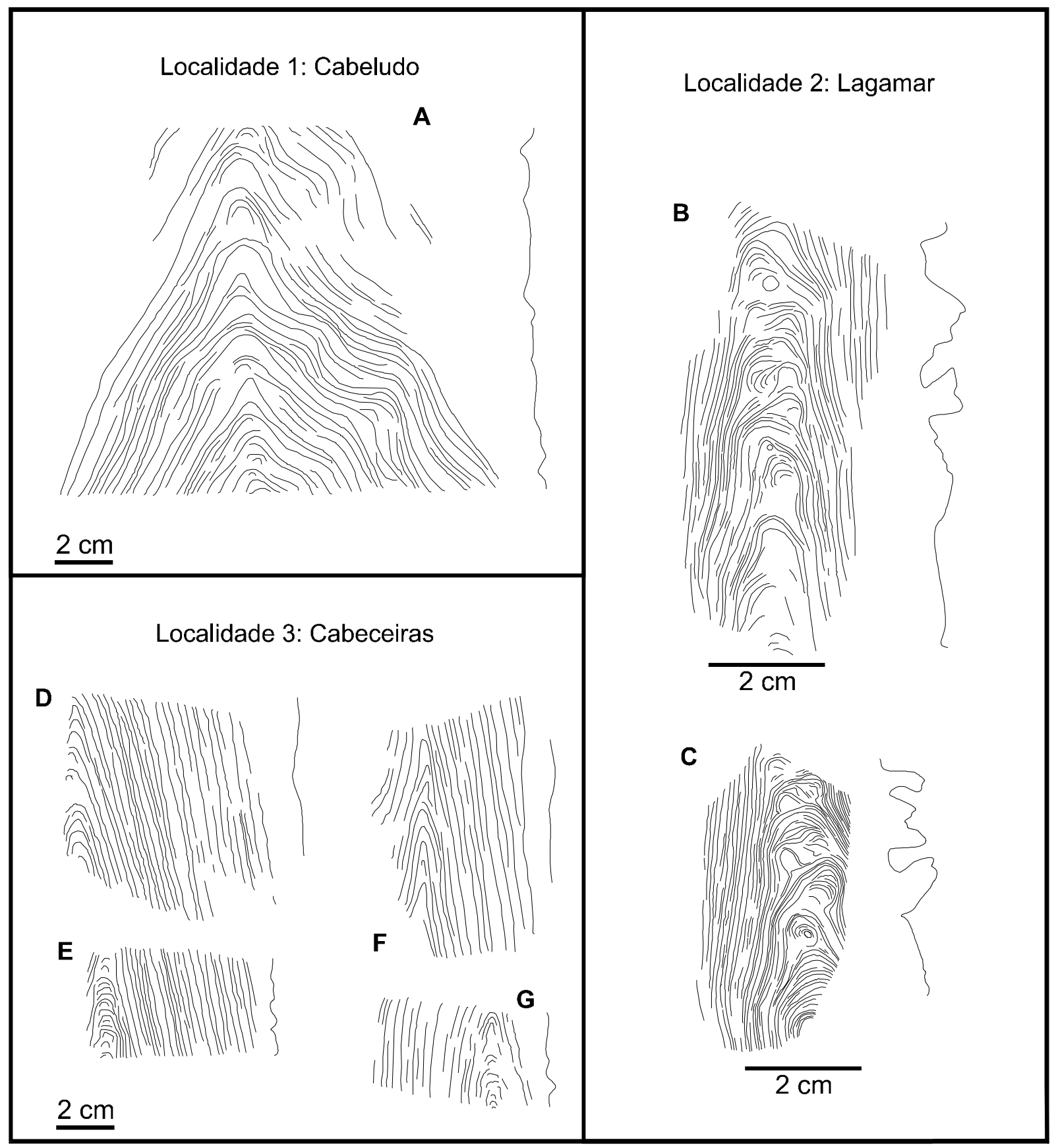

Figura 48: Detalhes das zonas axiais e traços axiais em amostras do Grupo Paranoá. A- Amostra CPAR-05 (Est. XV-A); B e C- Amostra CPAR-07 (Est. XV-E e F); D e E- Amostra CPAR-06 (Est. XVI-A e B); F e G- Amostra CPAR-10 (Est. XVI-E).

Um desenho da laminação elaborado a partir de fotografia de lâmina petrográfica (Est. XV-D) mostra o aspecto irregular da laminação e a distribuição das lâminas claras e escuras (Figura 49), bem como as porções recristalizadas. Através destes desenhos observa-se que existe uma maior densidade de lâminas claras (originais) do que de escuras (Figura 49). 


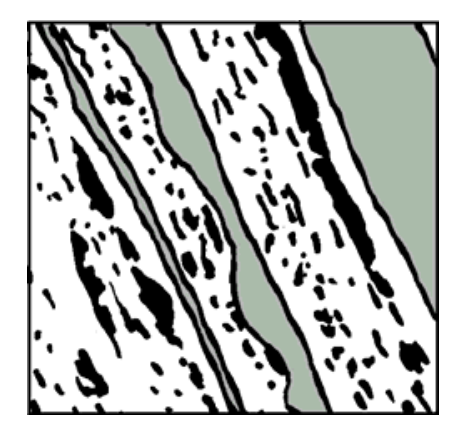

Figura 49: Desenho da laminação elaborado a partir de fotografia de lâmina petrográfica da amostra CPAR-05 (Est. XV-D). As partes em cinza correspondem as porções recristalizadas. A área representada corresponde a $1 \mathrm{~cm}^{2}$.

A segunda localidade está situada a cerca de $6,5 \mathrm{~km}$ a oeste de Lagamar (MG), nas margens do Rio Carrapato (Campos Neto, 1979), descrita por Dardenne \& Campos Neto (1976) e Campos Neto (1979) como Conophyton metulum (Figura 46, Ponto 2). A amostra analisada desta localidade (CPAR-07) é composta por colunas cilíndricas (C.5), com contornos transversais arredondados a elípticos (F.1 e 3). Em perfil longitudinal tem laminação pontiaguda com zona axial (N.8) formando um ângulo apical de cerca de $30^{\circ} \mathrm{e}$ apresenta relevo sinótico alto de, no mínimo, $6 \mathrm{~cm}$ (Est. XV-E e F). A zona axial é larga, de 1 a 1,5 cm (Figura 48 B e C; Est. XV-E e F). Os traços axiais exibem baixo grau de regularidade e de herança laminar (Figura $48 \mathrm{~B}$ e C). A laminação é fina com lâminas claras e escuras bem definidas (Est. XV-E e F) e a espessura de L2 varia entre 0,04 e 1,14 mm (53 medidas) e de L1 entre 0,04 e 1,0 mm (52 medidas) (Figura 50). Há maior concentração entre 0,04 e $0,4 \mathrm{~mm}$, com picos em 0,1 e $0,3 \mathrm{~mm}$, para $L 2$, e entre 0,04 e $0,3 \mathrm{~mm}$, com picos em 0,1 e 0,3 mm, para L1. As lâminas possuem uma coloração rosa ora mais escuro ora mais claro.

Um desenho da laminação elaborado a partir de fotografia de lâmina petrográfica (Est. XV-F) revela uma laminação fina e uniforme, com maior densidade de lâminas escuras do que de claras (Figura 51). 


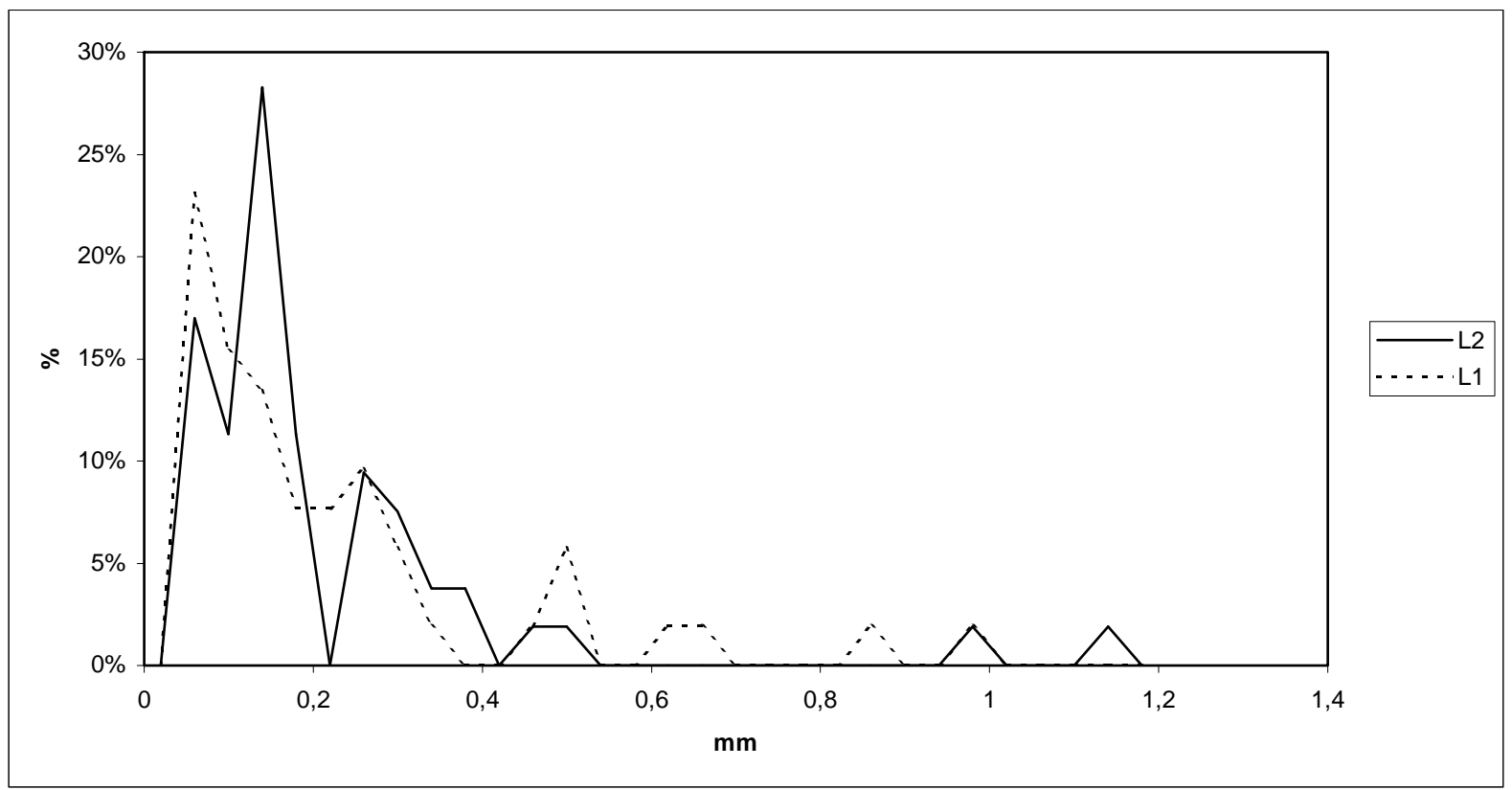

Figura 50: Freqüência relativa das lâminas escuras (L2) e claras (L1) da amostra CPAR-07. N=53 (L2) e 52 (L1).

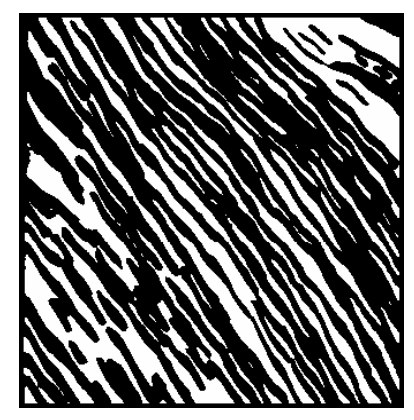

Figura 51: Laminação de Conophyton metulum, elaborado a partir de fotografia de lâmina petrográfica da amostra CPAR-07 (Est. XV-F). A área representada corresponde a $1 \mathrm{~cm}^{2}$.

A última localidade ocorre a $2 \mathrm{~km}$ a N30W de Cabeceiras (GO), na fazenda Funil (Figura 46, Ponto 3). Duas amostras foram analisadas (CPAR-06 e 10). São compostas de colunas cilíndricas (C.5), com contornos transversais elípticos (F. 3) (Est. XVI-C e F). Em perfil longitudinal apresenta laminação pontiaguda com zona axial (N.8), ângulo apical de 30 a $40^{\circ}$, no eixo menor, e relevo sinótico alto de, no mínimo, $15 \mathrm{~cm}$ (Est. XVI-A, B e E). A zona axial é estreita, com de 0,4 a 0,6 cm de largura (Figura 48 D a G; Est. XVI-A, B e E). Os traços axiais indicam alto a médio grau de regularidade e de herança laminar (Figura 48 D a G). No caso da amostra CPAR-06, a laminação é fina com lâminas claras e escuras irregulares, também visto em lâmina petrográfica (Est. XVI-B e D). Já na amostra CPAR-10, a laminação é mal definida, vestigial, devido à recristalização. Na amostra CPAR-06 as espessuras de L2 variam entre 0,04 e 1,3 mm (99 medidas) e de L1 entre 
0,04 e 1,0 mm (102 medidas) (Figura 52). Há maior concentração entre 0,04 e 0,3 mm, com picos em 0,15 e 0,26 mm, para L2, e entre 0,08 a 0,4 mm, com picos em 0,15, 0,26 e $0,4 \mathrm{~mm}$, para L1.

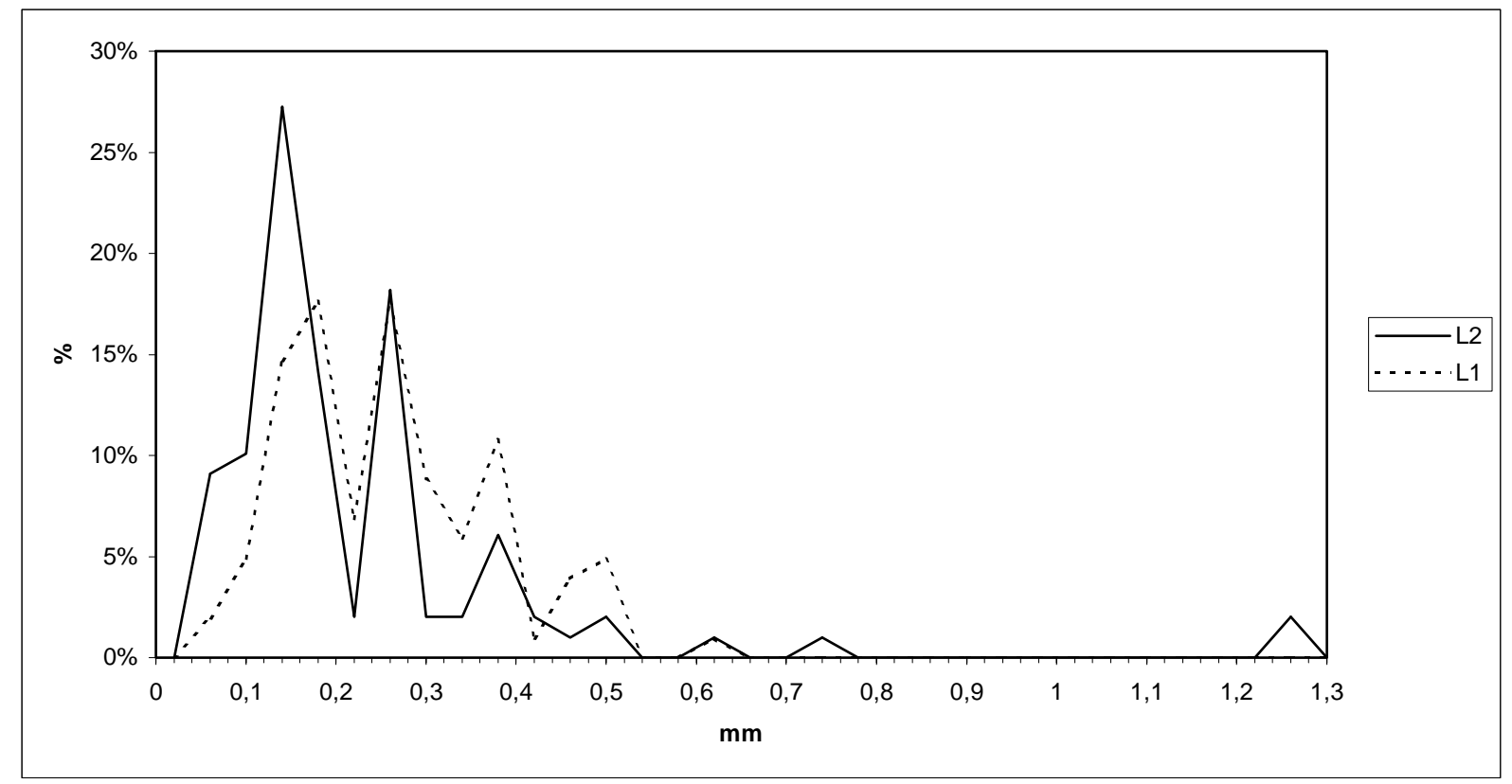

Figura 52: Freqüência relativa das lâminas escuras (L2) e claras (L1) da amostra CPAR-06. N=99 (L2) e 102 (L1).

Para a amostra CPAR-10, mais recristalizada, a espessura de L2 varia entre 0,04 e 0,9 mm (54 medidas) e de L1 entre 0,06 e 1,0 mm (54 medidas) (Figura 53). Há maior concentração entre 0,04 e 0,4 mm, com picos em 0,15, 0,26 e 0,4 mm, para L2, e entre 0,08 a 0,4 mm, com picos em 0,15, 0,26 e 0,4 mm, para L1.

Em um desenho da laminação elaborado a partir de fotografia de lâmina petrográfica da amostra CPAR-06 (Est. XVI-D), nota-se a laminação fina, com uma distribuição bem definida de lâminas claras e escuras (Figura 54). Através deste desenho nota-se que existe uma maior densidade de lâminas claras do que de escuras (Figura 54). 


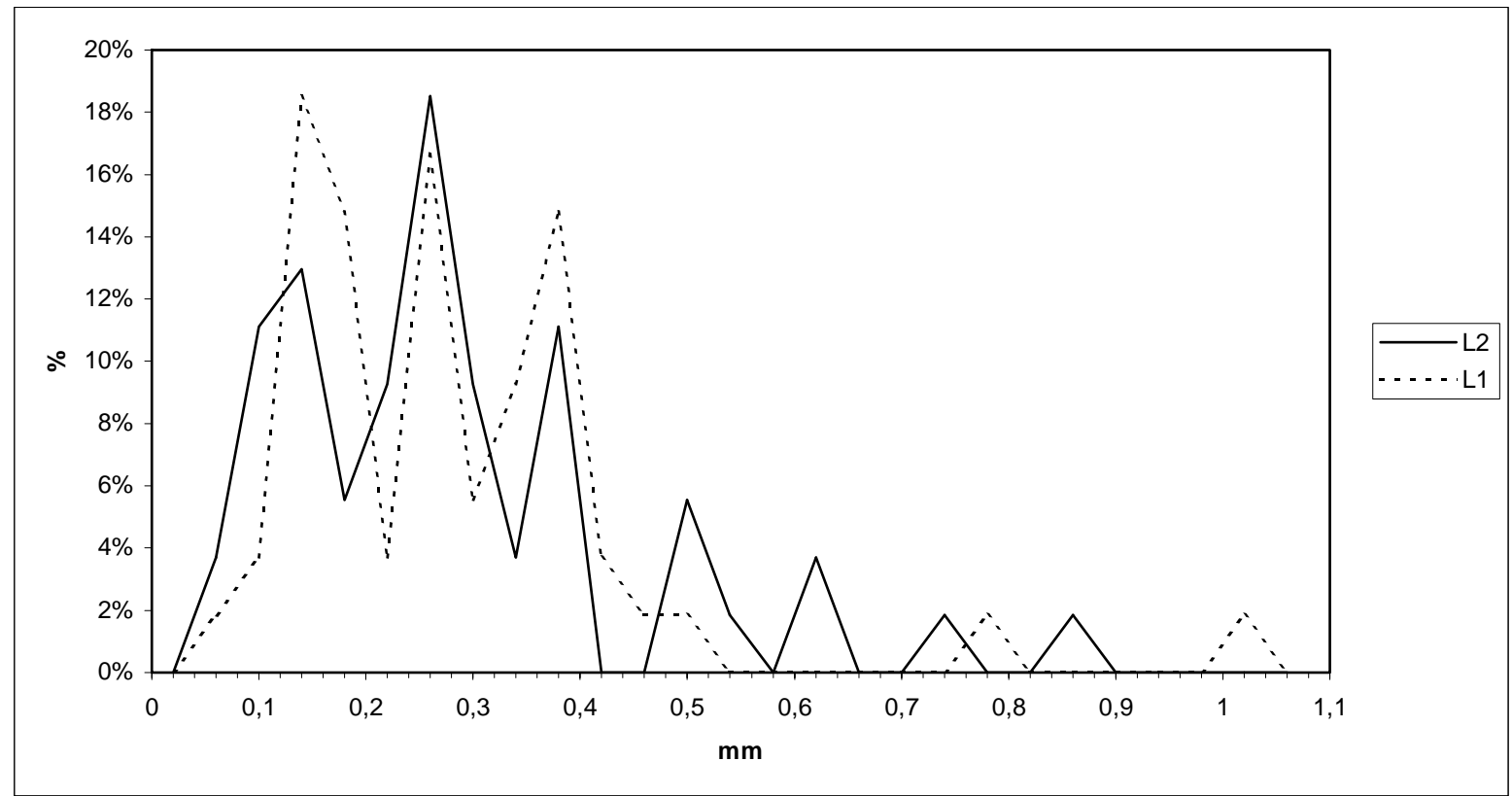

Figura 53: Freqüência relativa das lâminas escuras (L2) e claras (L1) da amostra CPAR-10. N=54 (L2 e L1).

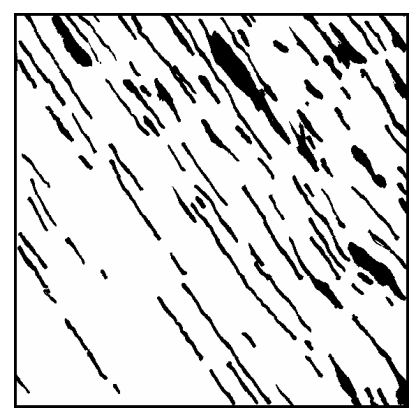

Figura 54: Desenho da laminação elaborado a partir de fotografia de lâmina petrográfica da amostra CPAR-06 (Est. XVI-D). A área representada corresponde a $1 \mathrm{~cm}^{2}$. 
ESTAMPA XV - Conophyton do Grupo Paranoá

A, B, C, D - Cabeludo, MG - Corte longitudinal ( $\mathrm{A}$ e C), com detalhe da zona axial (A e C) e transversal, exibindo contorno em planta elíptico (B) de uma coluna de Conophyton cylindricum. Em D, detalhe das faixas claras (recristalizadas) e escuras e da laminação com intercalação de lâminas claras e escuras presente nas faixas escuras. Amostra CPAR-05.

E, F - Lagamar, MG - Corte longitudinal de uma coluna de Conophyton metulum, com detalhe da zona axial larga e da laminação fina e bem definida. Amostra CPAR-07. 

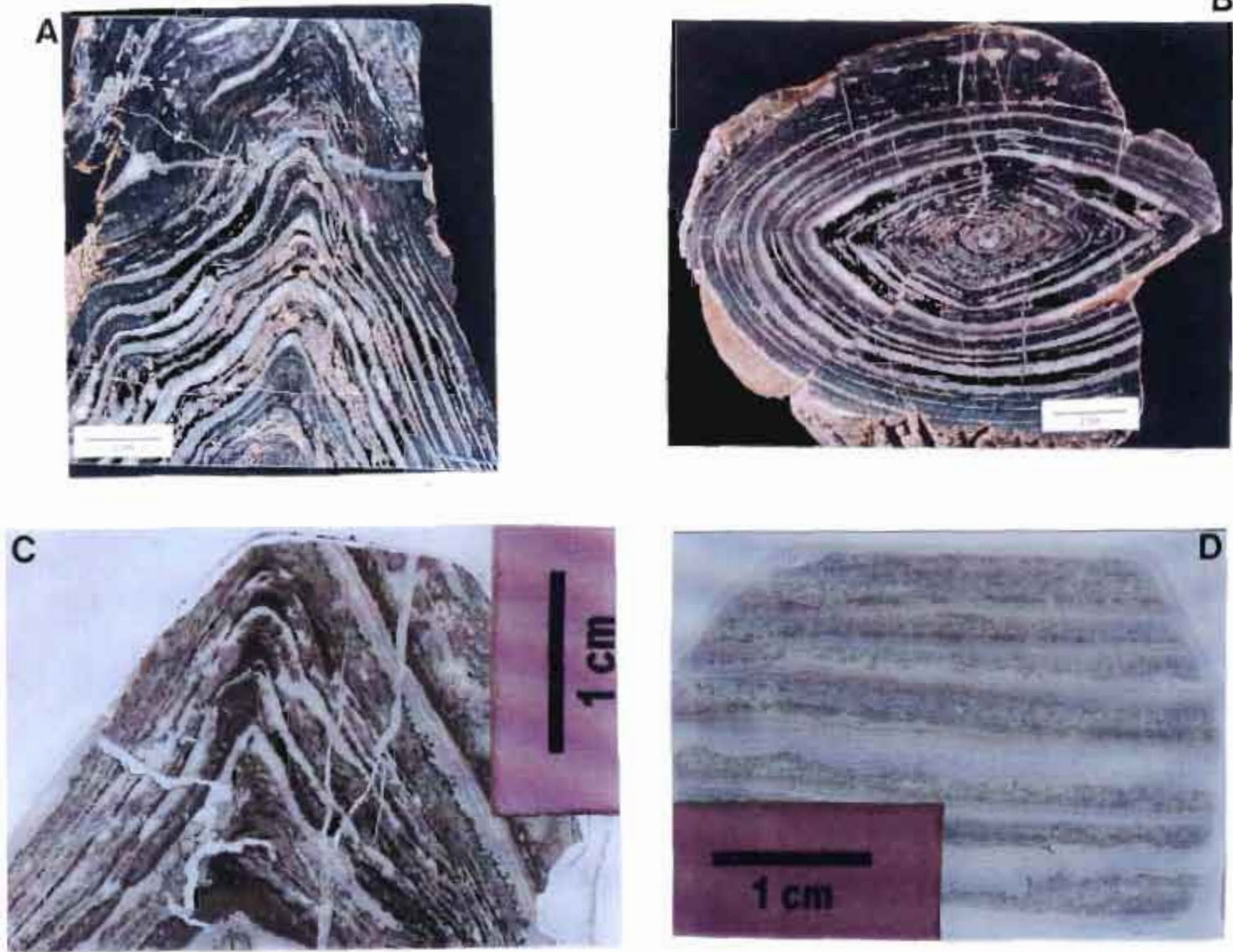

E

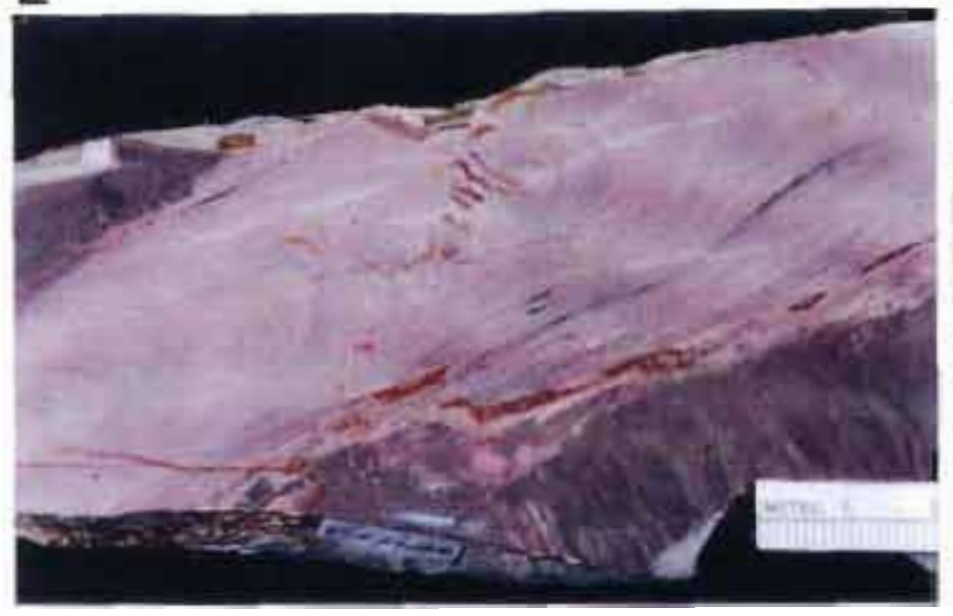

B 
ESTAMPA XVI - Conophyton do Grupo Paranoá, Cabeceiras, GO

A, B, C, D - Corte longitudinal, com detalhe da zona axial ( $\mathrm{A}$ e B) e transversal, exibindo contorno elíptico (D) de uma coluna de Conophyton cylindricum. Em D, um detalhe de parte da coluna da fotografia $B$, em lâmina petrográfica, mostrando a laminação. Em $A, a$ escala corresponde a 2,4 cm, em C a 4,5 cm. Amostra CPAR-06

E, F, G - Corte longitudinal, em lâmina petrográfica, com detalhe da zona axial e laminação mal definidas (E) e transversal com contornos elípticos de colunas de Conophyton cylindricum. Em G, um detalhe de parte da coluna da fotografia $\mathrm{E}$, mostrando a má preservação da laminação. Em F, a escala é de $4 \mathrm{~cm}$. Amostra CPAR-10. 

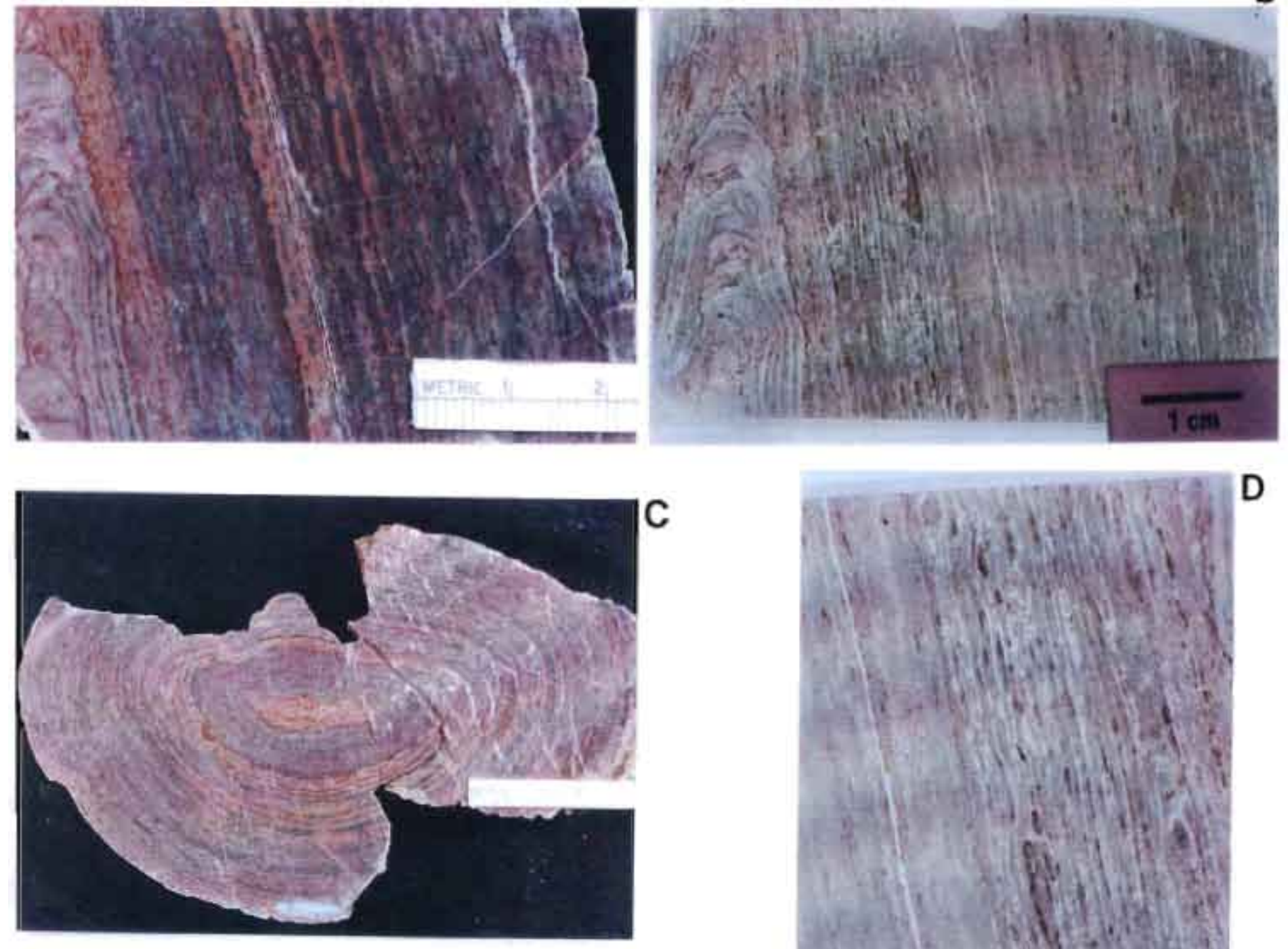

E
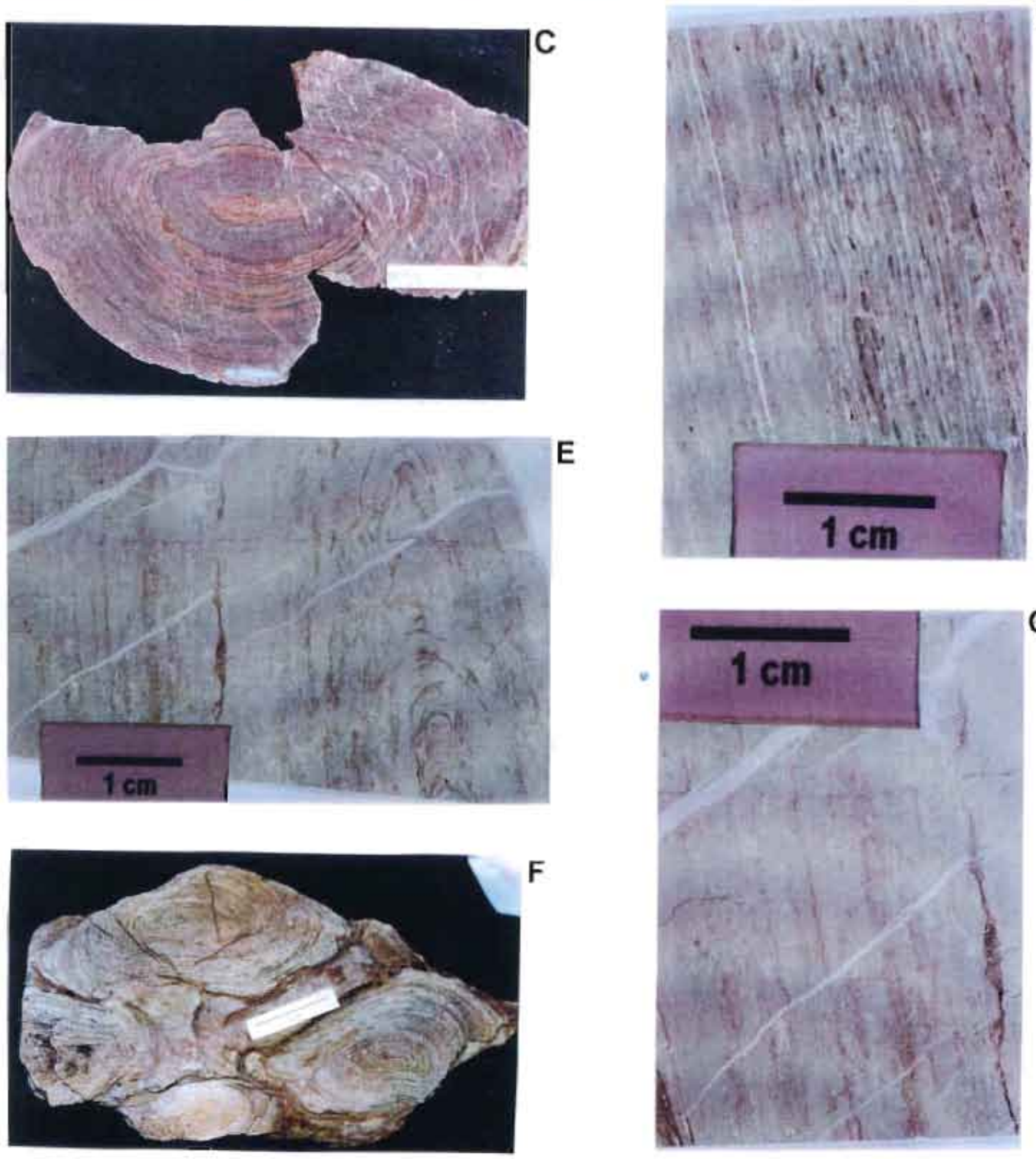

D

$E$

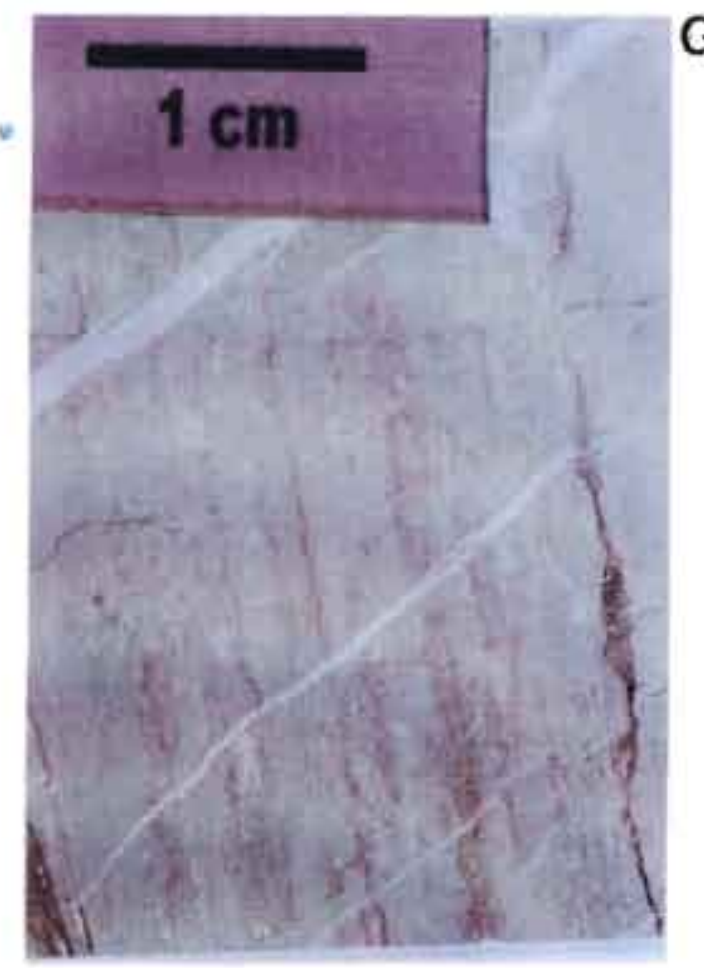




\section{DISCUSSÃO DOS RESULTADOS}

Através do estudo dos estromatólitos do Grupo Itaiacoca na região de Itapeva, pode-se identificar cinco formas, distintas entre si por diferenças na forma das colunas e laminação e também na existência de ramificação. As formas cônicas (Forma 1, Conophyton) são mais abundante e constituem os principais bioermas na área. Em LAV observou-se que Conophyton está associado a formas não cônicas (formas 2 e 3) e em IND também formas não cônicas no topo da seção.

As características dos estromatólitos estudados permitem desenvolver algumas interpretações paleoambientais. Primeiramente pode-se inferir águas relativamente mais profundas para os estromatólitos coniformes do tipo Conophyton, e mais raso, para os outros estromatólitos colunares. Dada a necessidade de luz para a proliferação dos microorganismos responsáveis pela formação dos estromatólitos, o desenvolvimento de estromatólitos abundantes deve ter ocorrido dentro da zona fótica, em águas relativamente limpas e bem iluminadas. Em LAV os estromatólitos ocorrem na base da sequência carbonática sendo recobertos por metacalcários estratificados, indicando também uma mudança de ambiente.

A geometria, simplicidade, uniformidade e delicadeza da laminação de Conophyton sugere sua formação sob condições relativamente profundas, uniformes e calmas. A forma cônica parece derivar de uma intensa competição para a luz entre os microorganismos formadores de Conophyton, havendo uma concentração muito grande na ponta da estrutura (Walter, 1977). Forma-se, com isso, um tipo de "bico", que, propagado em sucessivas lâminas, acaba criando a zona axial vista em cortes longitudinais pelo eixo do estromatólito. Um ambiente calmo é sugerido pela ausência de evidências de exposição sub-aérea ou de águas agitadas, que levariam ao ressecamento e/ou erosão, entulhando os espaços entre as colunas com fragmentos dos próprios estromatólitos ou de sedimentos grossos de outras origens. Por estes argumentos, considera-se que os estromatólitos coniformes devem ter se formado em águas não agitadas abaixo da ação das ondas normais, o que traduz em profundidades de até algumas dezenas de metros (Figura 28).

Estromatólitos não cônicos, colunares ou não, caracterizados por grande variedade laminar e morfológica, deveriam ter se formado sob condições mais rasas e mais variadas em relação à exposição sub-aérea e agitação da água (Hoffman, 1976; Grotzinger, 1989). Mas o que se observa ao sul de Itapeva é que as formas não cônicas são raras e com 
pouca diversidade de formas e possuem pouca ou nenhuma evidência de águas rasas e agitadas. Apenas raramente ocorrem o que parecem ser fragmentos retrabalhados de estromatólitos no sedimento intercolunar. Deste modo estes estromatólitos também foram formados em águas relativamente profundas. Pelo menos para as formas 2 e 3, pode-se inferir um ambiente semelhante ao da Forma 1, com a qual elas podem estar associadas. Existe a possibilidade dessas formas (2 e 3) representarem águas mais agitadas ou de correntes maiores, entre ou no topo dos bioermas de Conophyton, em locais de correntes mais acentuadas. As formas divergentes são muito raras e devem indicar os ambientes mais agitados (mais raso) da região. Mas estas formas são raras e mal preservadas e pouco se sabe de suas relações com as outras formas.

Em LAV pode-se deduzir que houve um aumento de profundidade para o topo quando da deposição de fácies de calcários estratificados, em um ambiente que já não era mais propício para formação de estromatólitos por ser muito profundo.

As diferenças litológicas entre as duas principais ocorrências de estromatólitos coniformes na área sugerem ambientes ligeiramente diferentes. No caso dos metacalcários dolomíticos cinza claros, as formas coniformes, nem sempre apresentam zona axial bem desenvolvida o que pode indicar uma profundidade mais rasa, próxima ao limite para formação de estromatólitos cônicos.

Os metacalcários calcíticos cinza escuros, de pequena expressão em área em relação aos dolomíticos, podem ser estromatolíticos (IND e CHB) ou estratificados (Ponto 07). Neste caso considera-se que os estratificados são de águas mais profundas que os com estromatólitos. Os estromatólitos presentes nestes metacalcários são quase que unicamente cônicos o que sugere que as águas eram mais profundas do que para os metacalcários dolomíticos cinza claros estromatolíticos. Por outro lado, a profundidade não poderia ter sido muito grande, visto que a rocha é muito argilosa e, portanto, as águas poderiam ter sido algo turvas, impedindo a formação de estromatólitos em profundidades mais altas, devido à impossibilidade da passagem de luz. Esta fácies foi depositada em um ambiente fora da ação de ondas. Uma outra possibilidade é de que a presença de argila indique apenas uma proximidade a uma área fonte de material terrígeno, e não uma variação de profundidade.

Estes dois tipos de calcários apresentavam bioermas distintos, um que ocorria de maneira mais expressiva (LAV, e outras localidades), expandindo-se lateralmente formando um recife ao longo da costa, dada a ampla distribuição geográfica deste tipo de litologia, que praticamente ocorre ao longo de todo o Grupo Itaiacoca e outro mais restrito 
que formou os metacalcários calcíticos argilosos (IND e CHB). O caráter restrito e aparentemente isolado do bioerma de IND e CHB é demonstrado pelo fato de ocorrer apenas como uma única lente na região de Itapeva, a qual está circundada por metapelitos.

Dentro de uma classificação de ambientes deposicionais para carbonatos Précambrianos, como a de Grotzinger (1989), podemos considerar o ambiente para os carbonatos estromatolíticos da região de Itapeva como o de "rampa" dadas suas características:

- em águas profundas ocorrem folhelhos, formações ferríferas, ritmitos folhelho/carbonato, ritmitos de carbonatos laminados;

- em águas rasas ocorrem extensos recifes estromatolíticos.

Pode-se aplicar bem o modelo de Grotzinger (1989) ao caso dos metacalcários dolomíticos, como visto na Figura 55, onde ocorrem os estromatólitos cônicos se formando em águas mais profundas e outras formas colunares alongadas em águas mais rasas.

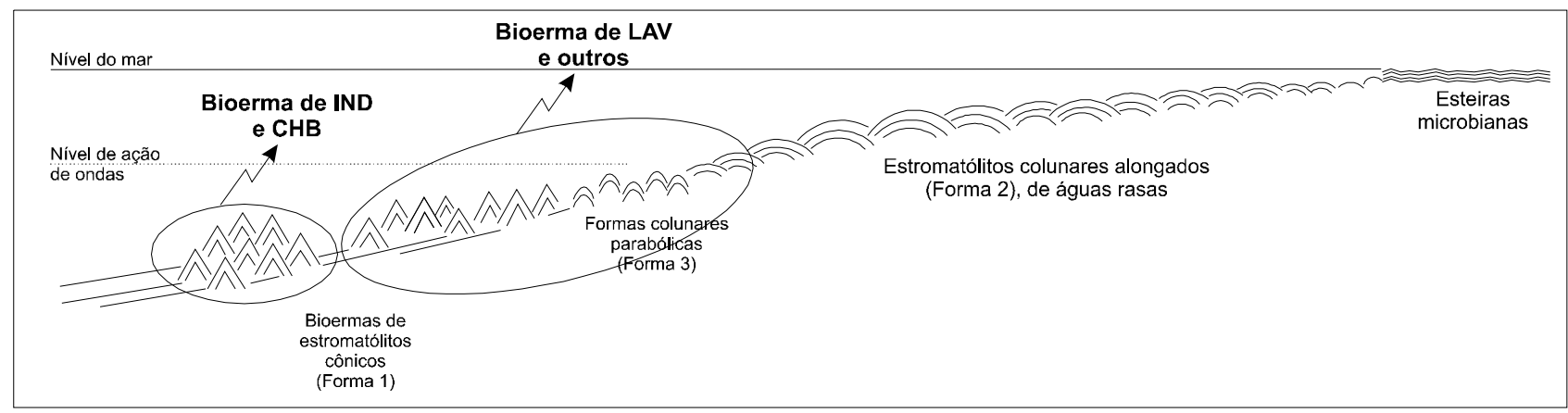

Figura 55: Relações entre os bioermas e suas respectivas formas, em um ambiente de rampa (modificado de Grotzinger, 1989).

A hipótese de que IND e CHB formariam um bioerma isolado pode ser incluída no modelo de Grotzinger (1989), que também descreve alguns bioermas que formam construções isoladas dentro de um ambiente de rampa. Esta construção isolada passaria vertical e lateralmente para pelitos, como observado em campo. Esta associação temporal com pelitos também é demonstrada pelo caráter da sedimentação intercolunar dos estromatólitos de IND e CHB. Atualmente este bioerma forma uma lente de orientação NE-SW com cerca de 3000 metros de comprimento por 500 metros de largura e encontrase dobrada e falhada, mas imagina-se que este corpo pode ter alcançado alguns quilômetros de extensão e largura. 
A ausência de estromatólitos estratiformes e de formas simples na área é algo fora do comum. Talvez se deva à deformação que simplesmente aniquilou-os ou ao ambiente de deposição em que estes carbonatos se formaram era profundo demais. As únicas seguras de carbonato de águas mais rasas no Grupo Itaiacoca são os oólitos da região de Bom Sucesso (Hachiro et al., 1992).

Trabalhos anteriores (Petri \& Suguio, 1969; Hachiro et al., 1992; Fassbinder, 1996) definem o ambiente de deposição do Grupo Itaiacoca como marinho de plataforma continental rasa. As características primárias dos tipos diferentes de metacalcários na área de estudo sugerem deposição em ambientes algo diferenciados entre si. Metacalcários com oólitos mais ao sul da área de estudo, na região de Bom Sucesso de Itararé (SP) (Hachiro et al., 1992) representariam os ambientes carbonáticos mais rasos, regionalmente.

A classificação de Conophyton cf. C. garganicum, proposta por Fairchild (1977), acarreta uma idade entre 0,85 e 1,7 Ga, na análise desse autor. Esta faixa de valores é coerente com as mais recentes datações radiométricas, que indicam uma idade mesoproterozóica superior para o Grupo Itaiacoca.

A análise comparativa de Conophyton das regiões de Itapeva (SP) e Abapã (PR), mostrou tantas semelhanças entre as amostras, principalmente em aspectos da zona axial, como a largura, grau de regularidade e de herança laminar, e da laminação, como a espessura de lâminas claras e escuras, que é possível todas à mesma forma, $C$. garganicum (Figura 56). 

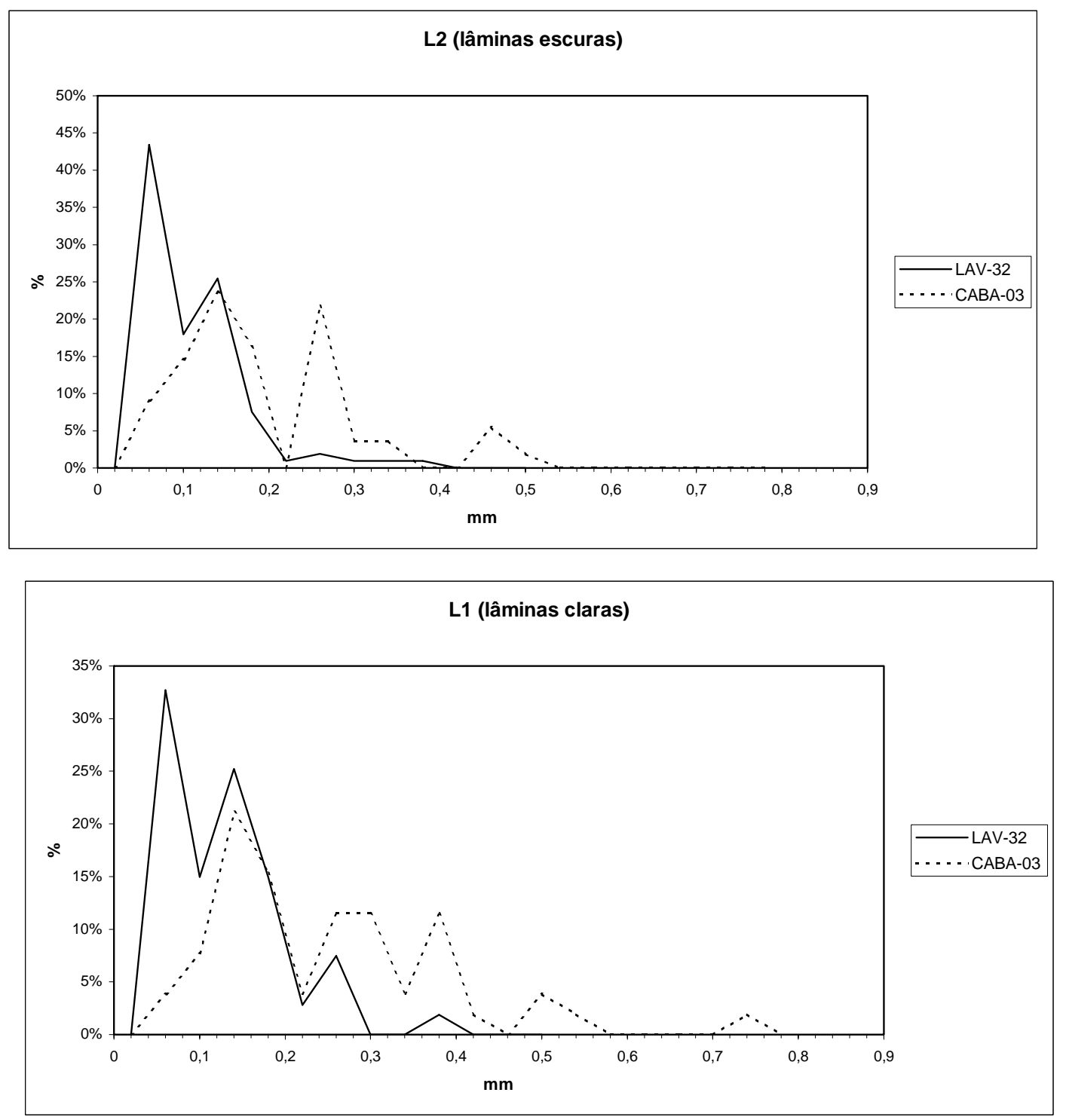

Figura 56: Comparação das freqüências relativas das lâminas escuras (L2) e claras (L1) das amostras LAV-32 (Itapeva) e CABA-03 (Abapã). Para LAV-32, N=106 (L2) e 107 (L1) e para CABA-03, N=55 (L2) e 52 (L1).

Por outro lado, a comparação de Conophyton das três localidades do Grupo Paranoá mostra uma clara separação entre as formas de Cabeludo e de Lagamar, bem como a semelhança entre as amostras de Cabeludo e Cabeceiras, por exemplo, em relação à espessura das lâminas claras e escuras (Figura 57), e aos padrões de laminação obtidos através dos desenhos das lâminas escuras (considerando apenas as porções não recristalizadas no caso das amostras de Cabeludo). Com relação à zona axial, as formas de Lagamar são muito mais largas do que nas formas das outras localidades, apresentando também graus de regularidade e herança laminar muito 
inferiores a estas. Tanto na largura quanto no grau de regularidade e de herança laminar da zona axial as formas de Cabeludo e Cabeceiras são semelhantes.
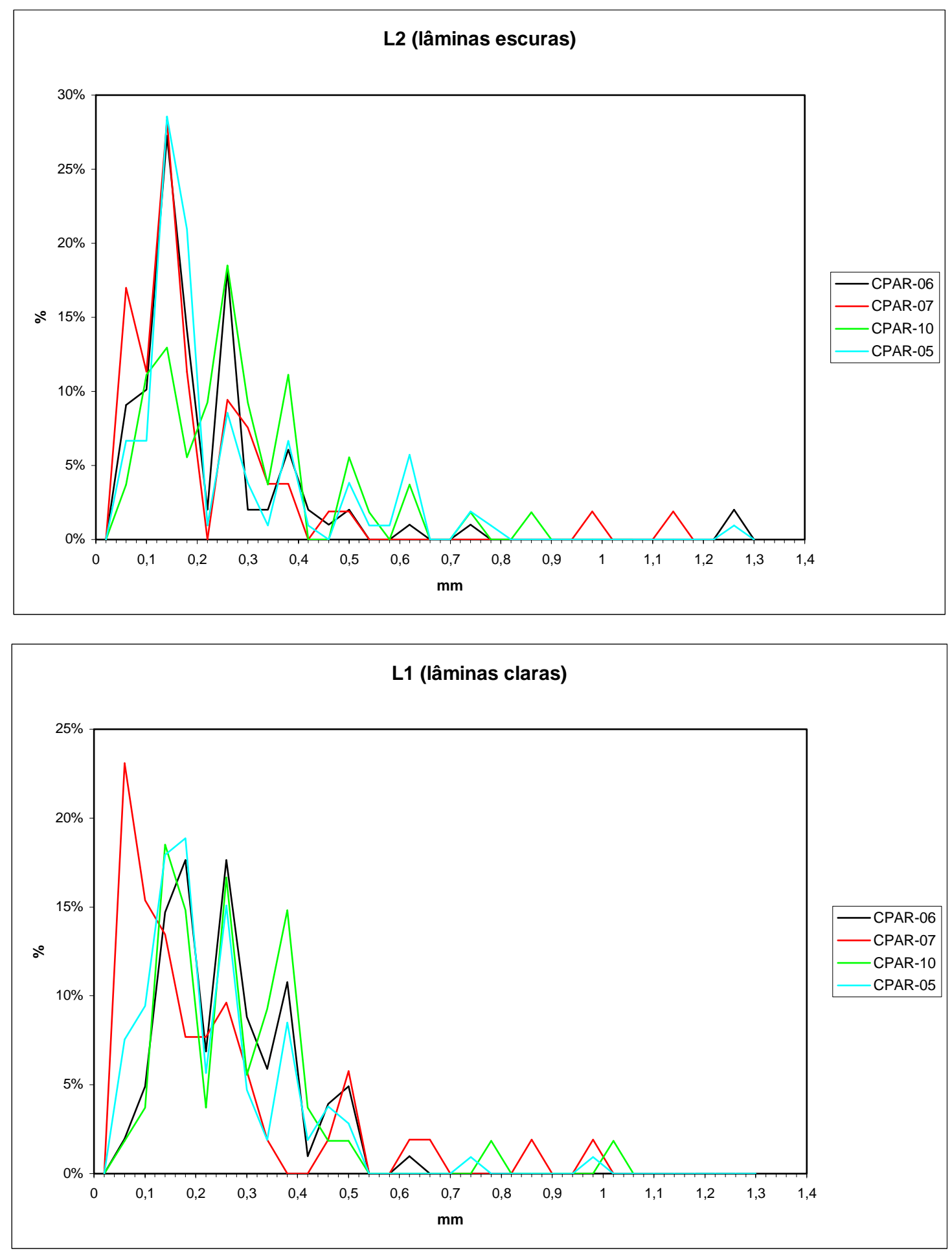

Figura 57: Comparação das freqüências relativas das lâminas escuras (L2) e claras (L1) das amostras de Cabeludo (CPAR-05), Cabeceiras (CPAR-06 e 10) e Lagamar (CPAR-07). Para CPAR-05, N=105 (L2) e 106 (L1); CPAR-06, N=99 (L2) e 102 (L1); CPAR-07, N=53 (L2) e 52 (L1) e CPAR-10, $N=54$ (L2 e L1). 
Comparando as formas de Conophyton do Grupo Itaiacoca com as do Grupo Paranoá, percebemos diferenças marcantes em diversos aspectos. O grau de regularidade e herança laminar da zona axial é parecido entre as formas do Grupo Itaiacoca (C. garganicum) e as formas do Grupo Paranoá, que ocorrem em Cabeludo e Cabeceiras (C. cylindricum), mas diferentes dos estromatólitos que ocorrem em Lagamar (C. metulum). Através dos gráficos de espessura da laminação, percebe-se que há diferenças entre as formas do Grupo Itaiacoca e as do Grupo Paranoá. As formas do Grupo Itaiacoca apresentam espessura mais fina, concentradas na faixa de 0,1 a 0,2 mm, tanto de L2 quanto de L1 (Figura 58). As lâminas das formas do Grupo Paranoá possuem espessura mais grossa e são distribuída de maneira mais uniforme entre 0,1 e 0,5 mm, tanto de L2 quanto de L1 (Figura 58).

Com base nisto não é possível correlacionar as formas de Conophyton do Grupo Itaiacoca com as do Grupo Paranoá. A implicação disso é que estas duas unidades teriam idades ou ambientes diferentes. Como visto anteriormente as idades propostas não mostram uma diferença de tempo muito grande. Deste modo as diferenças entre as formas deve ser, principalmente, um reflexo do ambiente de deposição, sem haver uma ligação destas duas unidades pelo mesmo mar durante o Mesoproterozóico. 

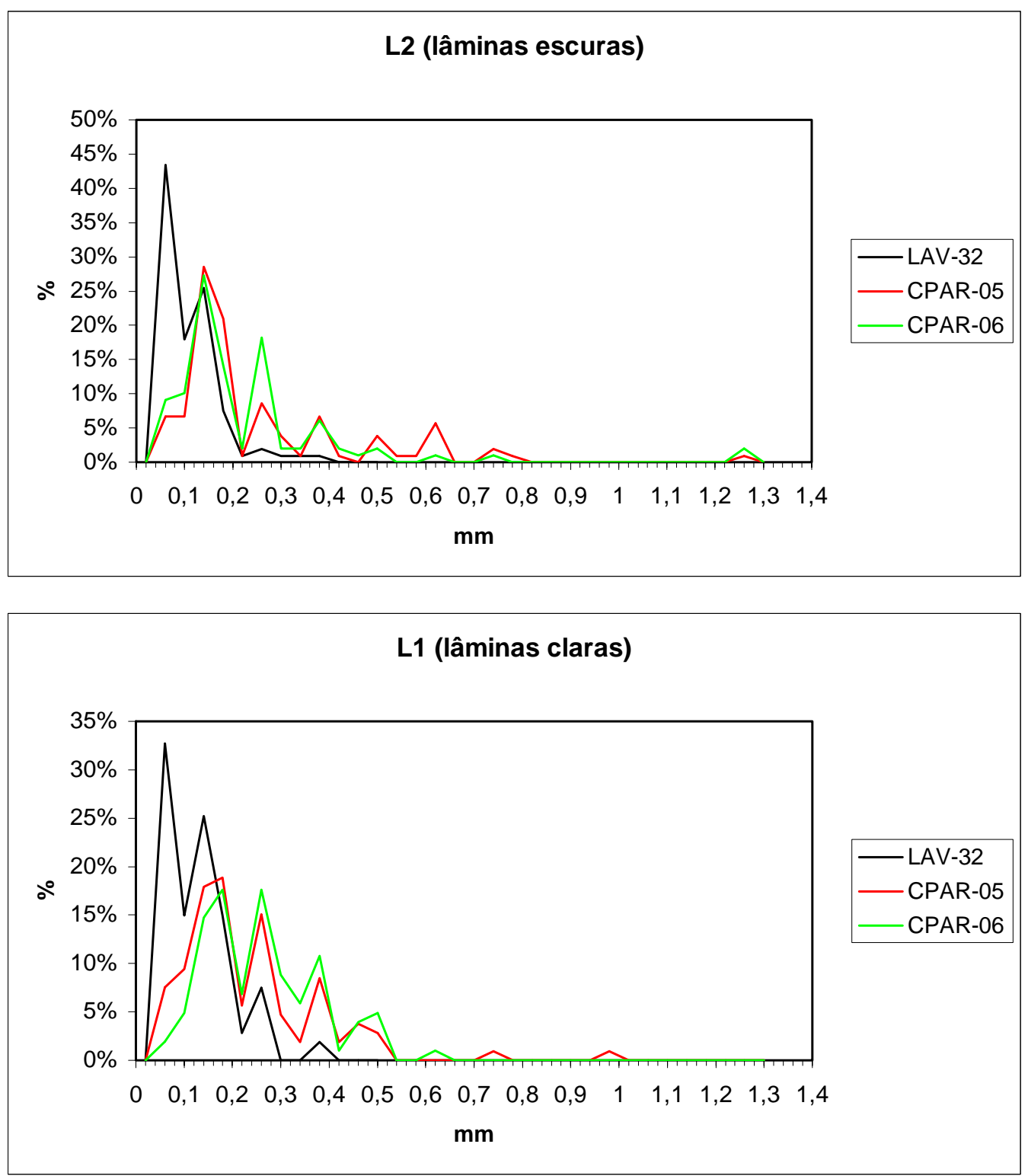

Figura 58: Comparação das freqüências relativas das lâminas escuras (L2) e claras (L1) das amostras de Itapeva (LAV-32), Cabeludo (CPAR-05) e Cabeceiras (CPAR-06). Para LAV-32, $\mathrm{N}=106$ (L2) e 107 (L1); CPAR-05, N=105 (L2) e 106 (L1) e CPAR-06, N=99 (L2) e 102 (L1). 


\section{CONCLUSÕES}

O estudo dos estromatólitos do Grupo Itaiacoca na região ao sul de Itapeva (SP), permitiu caracterizar os morfotipos presentes, estabelecer seu modo de ocorrência e distribuição na área, inferir as condições paleoambientais de sua formação, quantificar seu comportamento tectônico e investigar sua semelhança a formas de outras partes do Grupo Itaiacoca e até da margem do Cráton do São Francisco. As principais conclusões deste estudo são:

1) Foram distinguidas cinco formas distintas, todas colunares, enumeradas de um a cinco. A forma mais comum é coniforme, relacionada a Conophyton, possivelmente Conophyton garganicum. As outras quatro formas, não cônicas, são raras e exibem maior variedade de tipos, com laminação convexa a parabólica, e alguns são ramificados.

2) Ocorrem dois tipos principais de bioermas: um tabular mais extenso e mais comum, desenvolvido em metacalcários dolomíticos, e outro dômico/lenticular raro e isolado, constituído de metacalcários calcíticos mais argilosos.

3) Dadas a abundância das formas cônicas e a ausência de evidências de retrabalhamento, sugere-se um ambiente de deposição para os calcários estromatolíticos em águas relativamente profundas, abaixo da ação das ondas, com até algumas dezenas de metros. Ambientes carbonáticos de águas notadamente rasas não são observados na área, sendo que os ambientes julgados mais rasos estão evidenciados pelas formas estromatolíticas não cônicas. Os estromatólitos estariam distribuídos em ambiente de rampa.

4) A distribuição temporal dos estromatólitos do tipo Conophyton garganicum, entre 0,85 e 1,7 Ga, é coerente com a idade mesoproterozóica terminal obtida mais recentemente para o Grupo Itaiacoca por métodos geocronológicos.

5) A utilização de estromatólitos para quantificar a deformação tectônica, teve sucesso, e mostrou que a deformação foi intensa em toda a área, mas os estromatólitos nos metacalcários calcíticos apresentam-se mais deformados (com razões de strain em torno de 2) do que aqueles nos metacalcários dolomíticos (com razões de strain em torno de 1,3), devido à maior quantidade de impurezas nos metacalcários calcíticos. 
6) A comparação entre as formas de Conophyton no Grupo Itaiacoca, em Itapeva (SP) e Abapã (PR), mostrou que são suficientemente semelhantes entre si para poder considerá-las como pertencentes a mesma forma.

7) A comparação entre as formas de Conophyton do Grupo Paranoá mostrou que Conophyton cylindricum de Cabeludo (MG) e de Cabeceiras (GO) são semelhantes entre si, mas diferentes de C. metulum que ocorrem na região de Lagamar (MG).

8) As formas de Conophyton presentes no Grupo Itaiacoca diferem daquelas presentes no Grupo Paranoá, sugerindo ambientes de formação e/ou idades algo distintos. 


\section{REFERÊNCIAS BIBLIOGRÁFICAS}

Almeida, F.F.M. de 1944. Collenia itapevensis sp. n. - um fóssil pré-cambriano do Estado de São Paulo. Bol. Fac. Fil. Ciências e Letras, Univ. de São Paulo. XLV, Geologia n. 1, p. 89-106.

Almeida, F.F.M. de 1957. Novas ocorrências de fósseis no pré-cambriano brasileiro. Anais da Academia Brasileira de Ciências, v. 29, p. 63-72.

Almeida, F.F.M. de; Hasui, Y.; Brito Neves, B.B. de 1976. The Upper Precambrian of South America. Boletim IG, Instituto de Geociências, USP, v. 7, p. 45-80.

Awramik, S.M. 1971. Precambrian columnar stromatolite diversity: Reflection of metazoan appearence. Science, v. 174, p. 825-827.

Awramik, S.M. 1991. Archaean and Proterozoic stromatolites. In: Riding, R., ed., Calcareous Algae and Stromatolites. Springer-Verlag, p. 289-304.

Bergmann, M. \& Fairchild, T.R. 1985. Estromatólitos no Grupo São Roque, Proterozóico Superior, região de Pirapora do Bom Jesus, Estado de São Paulo. Anais da Academia Brasileira de Ciências, v. 57, p. 117.

Bertrand-Sarfati, J. 1972. Stromatolites columnaires du Pre-cambrien superior, Sahara nordoccidental - Inventaire, morphologie et microstructure des laminations, correlations stratigraphiques. Centre National de la Recherche Scientifique, Centre de Recherches sur les Zones Arides. Sér. Geologie, n. 14, 245 p.

Bigarella, J.J. \& Salamuni, R. 1958. Estudos preliminares na série Açunguí VIII - A Formação Votuverava. Boletim do Instituto de História Natural, Geologia, n. 2, 6 p.

Bistrichi, C.A.; Almeida, M.A. de; Stein, D.P. 1985. Geologia das folhas Barra do Chapéu (SG. 22X-B-I-4) e Araçaíba (SG. 22-X-F-II-3), estados de São Paulo e Paraná. IPT/PRÓ-MINÉRIO.

Bistrichi, C.A.; Carneiro, C.D.R.; Dantas, A.S.L.; Ponçano, W.L.; Campanha, G.A. da C.; Nagata, N.; Almeida, M.A. de; Stein, D.P.; Melo, M.S. de; Creminini, O. A.0 1981. Mapa geológico do Estado de São Paulo, escala 1:500.000. IPT/PRÓ-MINÉRIO, v. 2, mapa geológico.

Boggiani, P.C. 1997. Análise estratigráfica da Bacia Corumbá (Neoproterozóico) - Mato Grosso do Sul. Tese de Doutoramento, Instituto de Geociências/USP, 181 p. Inédito.

Boggiani, P.C.; Coimbra, A.M.; Fairchild, T.R. 1996. Stromatolitic reefs of the Bocaina Formation (Corumbá Group - Neoproterozoic-Cambrian) Mato Grosso do Sul, Brazil. Anais da Academia Brasileira de Ciências, Resumo das Comunicações, v. 68, n. 4, p. 596-597.

Burne, R.V. \& Moore, L.S. 1987. Microbialites: organosedimentary deposits of benthic communities. Palaios, v. 2, p. 241-254.

Campanha, G.A. da C. 1991. Tectônica proterozóica no alto e médio Vale do Ribeira, estados de São Paulo e Paraná. Tese de Doutoramento, Instituto de Geociências/USP, 295 p. Inédito.

Campanha, G.A. da C.; Bistrichi, C.A.; Almeida, M.A. 1987. Considerações sobre a organização litoestratigráfica e evolução tectônica da faixa de dobramentos Apiaí. III Simp. Sul-brasileiro de Geologia, Atas, Curitiba, v. 2, p. 725-742.

Campanha, G.A. da C. \& Sadowski, G.R. 1998. Cinturão Ribeira: tectônica e questões pendentes sobre sua evolução. XL Congresso Brasileiro de Geologia, Belo Horizonte, MG, Anais, p. 17.

Campos Neto, M. da C. 1979. Contribution à l'étude des Brasilides - Lithostratigraphie et structures des Groupes Canastra, Paranoa et Bambui dans l'Ouest-Nord-Ouest de l'Etat de Minas Gerais - Brésil. Dissertação de Mestrado (Thesis de $3^{\mathrm{e}}$ Cycle). Univ. Pierre et Marie Curie, Paris, 155 p. Inédito.

Carvalho, M.D de 1988. Carbonatos lacustres das bacias da margem continental brasileira. XXXV Congresso Brasileiro de Geologia, Belém, PA, Anais, v. 2, p. 801-808. 
Cassedanne, J.P. \& Cassedanne, J.O. 1978. Les stromatolites globuleux de la Fazenda Serra Virgem (Minas Gerais). Revista Brasileira de Geociências, v. 8, p. 219-234.

Chiodi Filho, C. 1984. Contribuição à geologia das regiões sul paulista e leste paranaense grupos Açungui e Setuva. XXXIII Congresso Brasileiro de Geologia, Rio de Janeiro, RJ, Anais, v. 5, p. 2394-2406.

Cloud, P. \& Dardenne, M. 1973. Proterozoic age of the Bambui Group in Brazil. Geological Society of America Bulletin, v.84, p. 1673-1676.

Cloud, P. \& Moeri, E. 1973. Conophyton in the Bambui Group: what form and age? Geology, v. 1, p. 127.

Cordani, U.G. \& Bittencourt, I. 1967a. Determinações de idade potássio-argônio em rochas do Grupo Açungui. XXI Congresso Brasileiro de Geologia, Anais, Curitiba, PR, p. 218-233.

Cordani, U.G. \& Bittencourt, I. 1967b. Estudo geocronológico no Grupo Açungui. Boletim Paranaense de Geociências, n. 26, p. 58-59.

Cordani, U.G. \& Kawashita, K. 1971. Estudo geocronológico pelo método Rb-Sr, de rochas graníticas intrusivas no Grupo Açungui. XXV Congresso Brasileiro Geologia, São Paulo, SP, Anais, p. 105-110.

Dardenne, M.A. \& Campos Neto, M.C. 1975. Estromatólitos colunares na Série Minas (MG). Revista Brasileira de Geociências, v.5, p. 99-105.

Dardenne, M.A. \& Campos Neto, M.C. 1976. Geologia da região de Lagamar (Minas Gerais). XXIX Congresso Brasileiro de Geologia, Resumos, Belo Horizonte, MG, p. 17.

Dardenne, M.A. \& Faria, A. de 1985. Estratigrafia do Grupo Paranoá na região de Alto Paraíso GO. II Simpósio de Geologia do Centro-Oeste, Anais, Goiânia, GO, p. 65-71.

Davis, G.H. \& Reynolds, S.J. 1996. Structural geology of rocks and regions. 776 p.

Donaldson, J.A. 1976. Paleoecology of Conophyton and associated stromatolites in the Precambrian Dismal Lakes and Rae Groups, Canada. In: Walter, M.R., ed., Stromatolites, Elsevier Sci. Publ. Co., Amsterdam, p. 523-534.

Donaldson, J.A. \& Taylor, A.H. 1972. Conical-columnar stromatolites and subtidal enviroment. American Association Petroleum Geologists Bulletin, v. 56, p. 614.

Fairchild, T.R. 1977. Conophyton and other columnar stromatolites from the Upper Precambrian Açungui Group near Itapeva, SP, Brazil. I Simpósio Regional de Geologia, São Paulo, SP, Atas, p. 179-198.

Fairchild, T.R. 1982. New stromatolites from the Upper Precambrian Açungui Group, eastern Paraná, Brazil, and their potential stratigraphic use. Boletim IG, Instituto de Geociências, USP, v. 13, p. 43-50.

Fairchild, T.R. \& Theodorovicz, A. 1989. Novas ocorrências de estromatólitos no Grupo Itaiacoca (Proterozóico médio a superior), sul do Estado de São Paulo. XI Congresso Brasileiro de Paleontologia, Curitiba, PR, Resumos, p. 4.

Fairchild, T.R.; Coimbra, A.M.; Boggiani, P.C. 1985. Ocorrência de estromatólitos silicificados na Formação Irati (Permiano) na borda setentrional da Bacia do Paraná (MT, GO). Anais da Academia Brasileira de Ciências, v. 57, p. 117.

Fairchild, T.R.; Schopf, J.W.; Shen-Miller, J.; Guimarães, E.M.; Edwards, M.D.; Lagstein, A.; Li, X.; Pabst, M.; Melo-Filho, L. S. de 1996. Recent discoveries of Proterozoic microfossils in southcentral Brazil. Precambrian Research, v. 80, p. 125-152.

Fassbinder, E. 1996. A unidade Água Clara no contexto do Grupo Açungui: um modelo transpressivo de colisão oblíqua no Neoproterozóico paranaense. Tese de Doutoramento, Instituto de Geociências/USP, 207 p. Inédito. 
Fry, N. (1979). Random point distributions and strain measurement in rocks. Tectonophysics, 60: 89-105.

Fuck, R.A. 1994. A Faixa Brasília e a compartimentação tectônica na Província Tocantins. IV Simpósio de Geologia do Centro-Oeste, Resumos expandidos, Goiânia, GO, p. 184-187.

Fuck, R.A.; Marini, O.J.; Dardenne, M.A.; Figueiredo, A.N. 1988. Coberturas metassedimentares do Proterozóico médio: os grupos Araí e Paranoá na região de Niquelândia-Colinas, Goiás. Revista Brasileira de Geociências, v. 18, n. 1, p. 54-62.

Golubic, S. 1976a. Organisms that build stromatolites. In: Walter, M.R., ed., Stromatolites, Elsevier Sci. Publ. Co., Amsterdam, p. 113-126.

Golubic, S. 1976b. Taxonomy of extant stromatolite-building cyanophytes. In: Walter, M.R., ed., Stromatolites, Elsevier Sci. Publ. Co., Amsterdam, p. 127-140.

Grey, K. 1989. Handbook for the study of stromatolites and associated structures. In: Kennard, J.M. \& Burne, R.V., eds., Stromatolite Newsletter, v. 14, p. 82-171.

Grotzinger, J.P. 1989. Facies and evolution of Precambrian carbonate depositional systems: Emergence of the modern platform archetype. In: Crevelo, P.D.; Wilson, J.L.; Sarg, J.F.; Read, J.F., eds., Controls on carbonate platforms and basin development, Special Publication of Society of Economic Paleontologists and Mineralogists, Tulsa, 44, p. 79-106.

Guia Quatro Rodas 1994. Guia de estradas. Editora Abril, p. 12-13.

Hachiro, J.; Frascá, M.H.B. de O.; Coimbra, A.M. 1992. Barras oolíticas da Formação Itaiacoca (Bom Sucesso, SP). XXXVII Congresso Brasileiro de Geololgia, São Paulo, SP, Resumos Expandidos, v. 2, p. 477-478.

Hasui, Y.; Carneiro, C.D.R.; Coimbra, A. M. 1975. The Ribeira folded belt. Revista Brasileira de Geociências, v. 5, p. 257-266.

Hasui, Y.; Cremonini, O.A.; Born, H. 1984. O "Granito Três Córregos" revisado e o Maciço Catas Altas. XXXIII Congresso Brasileiro de Geologia, Rio de Janeiro, RJ, Anais, v. 7, p. 30233031.

Hoffman, P. 1976. Enviromental diversity of middle Precambrian stromatolites. In: Walter, M.R., ed., Stromatolites, Elsevier Sci. Publ. Co., Amsterdam, p. 599-611.

Hofmann, H.J. 1969. Attributes of stromatolites. Geological Survey Canadian Paper 69-39, 58 p.

Hofmann, H.J. 1973. Stromatolites: characteristics and utility. Earth Science Reviews, v. 9, p. 339373.

Hofmann, H.J.; Grey, K.; Hickman, A.H.; Thorpe, R.I. 1999. Origin of 3,45 Ga coniform stromatolites in Warrawoona Group, western Australia. Geologial Society of America Bulletin, v. 111 , n. 8, p. $1256-1262$.

Krumbein, W.E. 1983. Stromatolites - The challenge of a term in space and time. Precambrian Research, v. 20, p. 493-531.

Krylov, I.N. 1976. Appraches to the classification of stromatolites. In: Walter, M.R., ed., Stromatolites, Elsevier Sci. Publ. Co., Amsterdam, p. 31-43.

Lemos, R.M.T. de \& Silva, C.G. 1994. Recent stromatolites of Salgada Lagoon, Rio de Janeiro state, Brazil. XIV International Sedimentological Congress, Abstracts, Recife.

Macedo, M.H.F. \& Bonhomme, M.G. 1984. Contribuição à cronoestratigrafia das formações Caboclo, Bebedouro e Salitre na Chapada Diamantina (BA) pelos métodos Rb/Sr e K/Ar. Revista Brasileira de Geociências, v. 14, n. 3, p. 153-163.

Marchese, H.G. 1974. Estromatolitos 'Gymnosolenidos' en el lado oriental de Minas Gerais, Brasil. Revista Brasileira de Geociências, v. 4, p. 257-271. 
Marini, O.J. \& Bigarella, J.J. 1967. Rochas calcárias do Grupo Açungui. Boletim Paranaense de Geociências, n. 23-25, p. 105-150.

Marini, O.J. \& Bósio, N.J. 1971. Estromatólitos em dolomitos do Grupo Açungui. Anais da Academia Brasileira de Ciências, v. 43, n.1, p. 161-175.

Marini, O.J.; Trein, E.; Fuck, R. 1967. O Grupo Açungui no estado do Paraná. Boletim Paranaense de Geociências, n. 23-25, p. 43-104.

Melo-Filho, L.S. 1996. Estromatólitos do Grupo Paranoá na região entre São Gabriel e Mato Seco/Mimoso (Goiás). Dissertação de Mestrado, Instituto de Geociências/UnB, 77 p. Inédito.

MINEROPAR, 1989. Mapa geológico do Estado do Paraná, escala 1:650.000.

Moeri, E. 1972. On a columnar stromatolite in the Precambrian Bambui Group of central Brazil. Eclogae Geologica Helvetica, v. 65, n. 1, p. 185-195.

Monteiro, M.C. \& Faria, R.T. de 1988. Planície de maré no poço 9-MO-13-RN, Formação Jandaíra um exemplo do passado. XXXV Congresso Brasileiro de Geologia, Belém, PA, Anais, v. 2, p. 809-823.

Nogueira, G.M.S. \& Dardenne, M.A. 1992. Caracterização dos dolomitos biohermais estromatolíticos da região de Lagamar, MG. XVII Congresso Brasileiro de Geologia, São Paulo, SP, Anais, p. 70-71.

Petri, S. \& Suguio, K. 1969. Sobre os metassedimentos do extremo sul do estado de São Paulo. Convênio USP/DAEE, 98 p. (Publ. Esp.).

Prazeres Filho, H.; Guimarães, G.; Basei, M.; Siga Jr.; Reis Neto, J.M. dos; Campanha, G.; Sallun Filho, W. 1998. Mapa geológico 1:50.000 da porção centro-sul da Faixa Itaiacoca - PR. XL Congresso Brasileiro de Geologia, Belo Horizonte, MG, Anais, p. 36.

Preiss, W.V. 1973. Palaeocological interpretations of South Australian Precambrian stromatolites. Journal of Geological Society of Australia, v. 19, p. 501-532.

Preiss, W.V. 1976a. Basic field and laboratory methods for the study of stromatolites. In: Walter, M.R., ed., Stromatolites, Elsevier Sci. Publ. Co., Amsterdam, p. 5-13.

Preiss, W.V. 1976b. Intercontinental correlations. In: Walter, M.R., ed., Stromatolites, Elsevier Sci. Publ. Co., Amsterdam, p. 359-370.

Raaben, M.E. 1969. Columnar stromatolites and Late Precambrian stratigraphy. American Journal of Science, v. 267, p. 1-18.

Ramsay, J.G. \& Huber, M.I. (1993). The techniques of modern structural geology - Volume 1: Strain Analysis. Academic Press, 307 p.

Reis Neto, J.M. dos 1983. Evolução geotectônica da bacia do Alto Tocantins, Goiás. Dissertação de Mestrado, Instituto de Geociências/USP, 98 p. Inédito.

Reis Neto, J.M. dos 1994. Faixa Itaiacoca: registro de uma colisão entre dois blocos continentais no Neoproterozóico. Tese de Doutoramento, Instituto de Geociências/USP, 253 p. Inédito.

Rohn, R. \& Fairchild, T.R. 1986. Estromatólitos permianos em calcário coquinóide do Grupo Passa Dois, nordeste do Paraná. Anais da Academia Brasileira de Ciências, v. 58, n. 3, p. 433-444.

Sallun Filho, W.; Fairchild, T.R.; Boggiani, P.C. 1997. Fósseis do Grupo Corumbá (Neoproterozóico), na Fazenda Ressaca, Serra da Bodoquena, Bonito (MS). XV Congresso Brasileiro de Paleontologia, São Pedro, SP, Resumos, p. 174.

Santoro, E. \& Frascá, M.H.B. de O. 1989. A Formação Itaiacoca na região de Itapeva, SP. I Simpósio de Geologia de Sudeste, RJ, Resumos, p 99-100.

Schopf, J.W. 1992. Patterns of Proterozoic microfossil diversity: An initial, tentative analysis. In: Schopf, J.W. \& Klein, C., ed., The Proterozoic biosphere - A multidisciplinary study, Cambridge University Press, p. 529-552. 
Semikhatov, M.A. 1976. Experience in stromatolite studies in the U.S.S.R. In: Walter, M.R., ed., Stromatolites, Elsevier Sci. Publ. Co., Amsterdam, p. 337-357.

Simonetti, C. \& Fairchild, T.R. (no prelo). Proterozoic microfossils from subsurface siliciclastic rocks of the São Francisco Craton, south-central Brazil. Precambrian Research.

Souza, A.P. 1990. Mapa geológico na escala 1:50.000 e esboço da evolução tectônica e sedimentar do Grupo Itaiacoca, nas folhas Barra do Chapéu e Ouro Verde - SP/PR. Dissertação de Mestrado, Instituto de Geociências/USP, 200 p. Inédito.

Souza, P.C. \& Müller, G. 1984. Primeiras estruturas algais comprovadas na Formação Gandarela, Quadrilátero Ferrífero. Revista da Escola de Minas, v. 37, n. 2, p. 13-21.

Srivastava, N. K. 1982. Algumas observações sobre os estromatólitos dos Grupos Una (Bahia) e Vaza Barris (Sergipe), nordeste do Brasil. Ciências da Terra, n. 3, p. 7-11.

Suguio, K. \& Melo e Souza, S.H. de 1985. Restos de mesossaurídeos na Formação Corumbataí, Permiano da Bacia do Paraná, no Estado de São Paulo. Anais da Academia Brasileira de Ciências, v. 57, n. 3, p. 339-347.

Takahashi, A.T.; Ferreira, J.C.G.; Thedorovicz, A. 1984. Projeto Guapiara. Relatório Final. CPRM/PROMINÉRIO.

Tassinari, C.C.G.; Siga Jr., O.; Teixeira, W. 1981. Panorama geocronológico do Centro-Oeste brasileiro: Soluções, problemática e sugestões. I Simpósio de Geologia do Centro-Oeste, Goiânia, GO, Anais, p. 93-116.

Thedorovicz, A.; Câmara, M.M.; Morais, S.M.; Godoy, H.K; Takahashi, A.T. 1986. Projeto Engenheiro Maia-Ribeirão Branco. Relatório Final. CPRM/PROMINÉRIO.

Thedorovicz, A.; Câmara, M.M.; Takahashi, A.T.; Morais, S.M.; Godoy, H.K. 1988. Geologia do Pré-Cambriano das folhas Engenheiro Maia e Ribeirão Branco, São Paulo. XXXV Congresso Brasileiro de Geologia, Belém, PA, Anais, v. 6, p. 2713-2726.

Thrailkill, J. 1976. Speleothems. In: Walter, M.R., ed., Stromatolites, Elsevier Sci. Publ. Co., Amsterdam, p. 73-86.

Trein, E.; Reis Neto, J.M. dos; Biondi, J.C.; Monastier, M.S. 1985. Revisão da Formação Itaiacoca: identificação de uma sequência metavulcano-sedimentar em Abapã (PR). V Simpósio Regional de Geologia, SP, Atas, v. 1, p. 169-185.

Trompette, R. 1982. Upper Proterozoic (1800-570 Ma) stratigraphy: A survey of lithostratigraphic, paleontological, radiochronological and magnetic correlations. Precambrian Research, v 18, p. 27-52.

Walter, M.R. 1972. Stromatolites and the biostratigraphy of the Australian Precambrian and Cambrian. Palaeontological Association of London, Special Papers in Palaeontology, n. 11, $190 \mathrm{p}$.

Walter, M.R. (ed.) 1976. Stromatolites. Elsevier Sci. Publ. Co., Amsterdam. 790 p.

Walter, M.R. 1977. Interpreting stromatolites. American Scientist, v. 65, p. 563-571.

Walter, M.R. 1992. Stratigraphic distribution of stromatolites and alied structures. In: Schopf, J.W. \& Klein, C., ed., The Proterozoic biosphere - A multidisciplinary study, Cambridge University Press, p. 507-509.

Walter, M.R. 1994. Stromatolites: the main geological source of information on the evolution of the early benthos. In: Bengtson, S., ed., Early life on earth. Nobel Symposium n. 84, Columbia University Press, New York, p. 270-286.

Walter, M.R.; Grotzinger, J.P.; Schopf, J.W. 1992. Proterozoic stromatolites. In: Schopf, J.W. \& Klein, C., ed., The Proterozoic biosphere - A multidisciplinary study, Cambridge University Press, p. 253-260. 
Zaine, M.F. 1991. Análise dos fósseis de parte da Faixa Paraguai (MS, MT) e seu contexto temporal e paleoambiental. Tese de Doutoramento, Instituto de Geociências/USP, 218 p. Inédito.

Zaine, M.F. \& Fairchild, T.R. 1992. Considerações paleoambientais sobre a Formação Araras, Faixa Paraguai, Estado de Mato Grosso. XXXVII Congresso Brasileiro de Geologia, São Paulo, SP, v. 2, p. 474-475. 


\section{ANEXOS}

\begin{tabular}{|c|c|c|c|c|c|c|c|}
\hline Localidade & $\begin{array}{l}\mathrm{n}^{0} \text { do } \\
\text { ponto }\end{array}$ & Coordenadas & Obs.: & Localidade & $\begin{array}{l}\mathrm{n}^{\mathrm{o}} \text { do } \\
\text { ponto }\end{array}$ & Coordenadas & Obs.: \\
\hline \multirow[t]{3}{*}{ LAV } & \multirow[t]{2}{*}{02} & $\begin{array}{l}722568 \\
7333029\end{array}$ & \multirow{2}{*}{$\begin{array}{l}\text { Coordenadas } \\
\text { do interior da } \\
\text { pedreira. }\end{array}$} & \multirow[t]{2}{*}{ ITN } & $16 a$ & $\begin{array}{l}706013 \\
7326990\end{array}$ & \\
\hline & & $\begin{array}{l}722536 \\
7333006\end{array}$ & & & $16 b$ & $\begin{array}{l}706123 \\
7326795\end{array}$ & \\
\hline & 27 & $\begin{array}{l}722434 \\
7332990\end{array}$ & & FSA & 17 & $\begin{array}{l}728933 \\
7337041\end{array}$ & \\
\hline \multirow[t]{5}{*}{ IND } & \multirow[t]{5}{*}{09} & $\begin{array}{l}717097 \\
7329036\end{array}$ & \multirow{5}{*}{$\begin{array}{l}\text { Coordenadas } \\
\text { do interior da } \\
\text { pedreira. }\end{array}$} & TGU & 19 & $\begin{array}{l}706751 \\
7325311\end{array}$ & \\
\hline & & $\begin{array}{l}717093 \\
7329163\end{array}$ & & IB1 & 31 & $\begin{array}{l}721831 \\
7331719\end{array}$ & \\
\hline & & $\begin{array}{l}717158 \\
7329060\end{array}$ & & IB2 & $35 a$ & $\begin{array}{l}721182 \\
7331122\end{array}$ & \\
\hline & & $\begin{array}{l}717114 \\
7328841\end{array}$ & & $\mathrm{CHB}$ & $44 a$ & $\begin{array}{l}718736 \\
7330354\end{array}$ & \\
\hline & & $\begin{array}{l}717039 \\
7328906\end{array}$ & & & $44 b$ & $\begin{array}{l}718785 \\
7330535\end{array}$ & \\
\hline \multirow[t]{2}{*}{ NCM } & $11 a$ & $\begin{array}{l}711021 \\
7327835\end{array}$ & & & & & \\
\hline & $11 b$ & $\begin{array}{l}711088 \\
7327902\end{array}$ & & & & & \\
\hline
\end{tabular}

Anexo 1: Coordenadas UTM das ocorrências de estromatólitos. 


\begin{tabular}{|l|l|c|c|c|c|}
\hline $\begin{array}{l}N^{0} \text { de } \\
\text { coleção }\end{array}$ & Localidade & Data de coleta & Data de entrada & Coletor & OBS.: \\
\hline IG-1 & $\begin{array}{l}\text { Campina dos Veados (atual } \\
\text { Nova Campina), Itapeva (SP) }\end{array}$ & & $24 / 10 / 46$ & $\begin{array}{c}\text { F.F.M. de } \\
\text { Almeida }\end{array}$ & $\begin{array}{c}2 \text { exemplares/ } \\
\text { Parátipo }\end{array}$ \\
\hline IG-139 & $\begin{array}{l}\text { Sítio Antônio Tavares, Bairro } \\
\text { Frias, Itapeva (SP) }\end{array}$ & $03 / 1949$ & $08 / 04 / 49$ & $\begin{array}{c}\text { J. Epitácio P. } \\
\text { Guimarães }\end{array}$ & 1 exemplar \\
\hline IG- 213 & $\begin{array}{l}\text { Campina dos Veados (atual } \\
\text { Nova Campina), Itapeva (SP) }\end{array}$ & & $24 / 04 / 62$ & $\begin{array}{c}\text { F.F.M. de } \\
\text { Almeida }\end{array}$ & 1 exemplar \\
\hline IG- 214 & $\begin{array}{l}\text { Pedreira Indumine, Alegre, } \\
\text { Itapeva (SP) }\end{array}$ & $10 / 1961$ & $25 / 04 / 62$ & $\begin{array}{l}\text { J. Epitácio P. } \\
\text { Guimarães }\end{array}$ & 1 exemplar \\
\hline
\end{tabular}

Anexo 2: Coleções do Instituto Geológico (Coleção Sérgio Mezzalira). 


\begin{tabular}{|l|l|c|c|c|c|}
\hline $\mathrm{N}^{0}$ de coleção & Localidade & $\begin{array}{c}\text { Data de } \\
\text { coleta }\end{array}$ & $\begin{array}{c}\text { Data de } \\
\text { entrada }\end{array}$ & Coletor & OBS.: \\
\hline GP/3T-80 & Itapeva (SP) & 1944 & & $\begin{array}{c}\text { F.F.M. de } \\
\text { Almeida }\end{array}$ & Parátipo \\
\hline $\begin{array}{l}\text { GP/3T-539a, } \\
\text { b, c, d, e }\end{array}$ & $\begin{array}{l}\text { Pedreira Lavrinhas, frente 7, } \\
\text { Itapeva (SP) }\end{array}$ & 1976 & $11 / 03 / 86$ & T.R. Fairchild & $\begin{array}{c}\text { Figs. 2a, c de } \\
\text { Fairchild (1977) }\end{array}$ \\
\hline GP/6E-14 & Pedreira Indumine, Itapeva (SP) & $21 / 10 / 80$ & $02 / 10 / 86$ & & \\
\hline GP/6E-15a, b & $\begin{array}{l}\text { Pedreira Chiquinho de Barros, } \\
\text { Itapeva (SP) }\end{array}$ & 1978 & $02 / 10 / 86$ & & \\
\hline
\end{tabular}

Anexo 3: Coleções do Laboratório de Paleontologia Sistemática - Depto. de Geologia Sedimentar e Ambiental, Instituto de Geociências/USP. 


\begin{tabular}{|c|c|c|c|c|}
\hline $\mathrm{N}^{\mathrm{O}}$ & $\mathrm{N}^{0}$ de coleção & Localização & Unidade & Obs. \\
\hline CITA-01 & $S / n^{0}-D N P M$ & Itapeva (SP) & Gr. Itaiacoca & Almeida (1944) \\
\hline CABA-02 & GP/6E - 148 & Areia do Meio, Abapã (PR) & Gr. Itaiacoca & \\
\hline CABA-03 & GP/6E - 149 & Rio Morcego, Palmito, Abapã (PR) & Gr. Itaiacoca & \\
\hline CABA-04 & GP/6E -150 & Rio Morcego, Palmito, Abapã (PR) & Gr. Itaiacoca & \\
\hline CPAR-05 & GP/6C-3a, b & Cabeludo, Vazante (MG) & Gr. Paranoá & $\begin{array}{l}\text { Moeri (1972); Cloud \& } \\
\text { Dardenne (1973) }\end{array}$ \\
\hline CPAR-06 & GP/6E - 151 & Fazenda Funil, Cabeceiras (GO) & Gr. Paranoá & Fairchild et al. (1996) \\
\hline CPAR-07 & GP/3T-540a, b, c & Lagamar (MG) & Gr. Paranoá & $\begin{array}{c}\text { Dardenne \& Campos Neto } \\
\text { (1976) }\end{array}$ \\
\hline CITA-08 & GP/3T-80 & Itapeva (SP) & Gr. Itaiacoca & Almeida (1944) \\
\hline CITA-09 & IG- 213 & Itapeva (SP) & Gr. Itaiacoca & Almeida (1944) \\
\hline CPAR-10 & GP/6E - 152 & Fazenda Funil, Cabeceiras (GO) & Gr. Paranoá & Fairchild et al. (1996) \\
\hline
\end{tabular}

Anexo 4: Amostras utilizadas para comparação, provenientes das Coleções do DNPM (Amostra 01), do Laboratório de Paleontologia Sistemática (Depto. de Geologia Sedimentar e Ambiental, IG/USP; Amostras 2 a 8, e 10) e do Instituto Geológico (Coleção Sérgio Mezzalira; Amostra 09). 


\begin{tabular}{|c|c|c|c|}
\hline \multicolumn{4}{|c|}{ Forma 1} \\
\hline $\begin{array}{l}\text { Número utilizado na } \\
\text { dissertação }\end{array}$ & Número de coleção & $\begin{array}{c}\text { Número utilizado na } \\
\text { dissertação }\end{array}$ & Número de coleção \\
\hline LAV-01 & GP/6E - 119 & IND-05 & GP/6E - 104 \\
\hline LAV-04 & GP/6E - 120 & IND-07 & GP/6E - 105 \\
\hline LAV-08 & GP/6E - 121 & IND-08 & GP/6E - 106 \\
\hline LAV-09 & GP/6E - 122 & IND-09 & GP/6E - 107 \\
\hline LAV-10 & $\mathrm{GP} / 6 \mathrm{E}-123$ & IND-10 & GP/6E - 108 \\
\hline LAV-16 & GP/6E - 124 & IND-11 & GP/6E - 109 \\
\hline LAV-21 & GP/6E - 125 & IND-15 & $\mathrm{GP} / 6 \mathrm{E}-110$ \\
\hline LAV-24 & GP/6E - 126 & IND-16 & $\mathrm{GP} / 6 \mathrm{E}-111$ \\
\hline LAV-25 & GP/6E - 127 & IND-22 & $\mathrm{GP} / 6 \mathrm{E}-112$ \\
\hline LAV-31 & GP/6E - 128 & IND-23 & $\mathrm{GP} / 6 \mathrm{E}-113$ \\
\hline LAV-32 & GP/3T - $539 a, b, c, d, e$ & IND-24 & $\mathrm{GP} / 6 \mathrm{E}-114$ \\
\hline & & IND-25 & GP/6E - 115 \\
\hline $\mathrm{CHB}-03$ & GP/6T-15 a, b & IND-28 & $\mathrm{GP} / 6 \mathrm{E}-116$ \\
\hline & & IND-29 & $\mathrm{GP} / 6 \mathrm{E}-117$ \\
\hline FSA-11 & GP/6E - 129 & IND-30 & $\mathrm{GP} / 6 \mathrm{E}-118$ \\
\hline \multicolumn{4}{|c|}{ Forma 2} \\
\hline $\begin{array}{l}\text { Número utilizado na } \\
\text { dissertação }\end{array}$ & Número de coleção & $\begin{array}{c}\text { Número utilizado na } \\
\text { dissertação }\end{array}$ & Número de coleção \\
\hline LAV-03 & GP/6E - 130 & LAV-28 & $\mathrm{GP} / 6 \mathrm{E}-137$ \\
\hline LAV-06 & GP/6E - 131 & LAV-29 & GP/6E - 138 \\
\hline LAV-11 & GP/6E - 132 & & \\
\hline LAV-12 & GP/6E - 133 & NCM-32 & GP/6E - 139 \\
\hline LAV-15 & GP/6E - 134 & & \\
\hline LAV-18 & GP/6E - 135 & IB1-07 & $\mathrm{GP} / 6 \mathrm{E}-140$ \\
\hline LAV-19 & GP/6E - 136 & & \\
\hline \multicolumn{4}{|c|}{ Forma 3} \\
\hline $\begin{array}{l}\text { Número utilizado na } \\
\text { dissertação }\end{array}$ & Número de coleção & $\begin{array}{c}\text { Número utilizado na } \\
\text { dissertação }\end{array}$ & Número de coleção \\
\hline IB1-01 & GP/6E - 141 & IND-14 & GP/6E - 144 \\
\hline IB1-02 & GP/6E - 142 & IND-31 & GP/6E - 145 \\
\hline LAV-18 & GP/6E -143 & & \\
\hline \multicolumn{4}{|c|}{ Forma 4} \\
\hline $\begin{array}{l}\text { Número utilizado na } \\
\text { dissertação }\end{array}$ & Número de coleção & $\begin{array}{c}\text { Número utilizado na } \\
\text { dissertação }\end{array}$ & Número de coleção \\
\hline IB2-01 & $\mathrm{GP} / 6 \mathrm{E}-146$ & TGU-20 & $\mathrm{GP} / 6 \mathrm{E}-147$ \\
\hline
\end{tabular}

Anexo 5: Amostras utilizadas na dissertação na caracterização das formas, com sua respectiva numeração e seus números de coleção (Coleção do Laboratório de Paleontologia Sistemática Depto. de Geologia Sedimentar e Ambiental, Instituto de Geociências/USP. 